\title{
An Exploration of the EU's Counterterrorism Measures: Can the EU Learn from its Member States? A Case Study Examining Italy
}

\author{
By
}

Lana Perić

\begin{abstract}
A thesis submitted to the Faculty of Graduate and Postdoctoral Affairs in partial fulfillment of the requirements for the degree of

Master of Arts

in

European, Russian, and Eurasian Studies
\end{abstract}

\section{Carleton University \\ Ottawa, Ontario}

(C) 2018

Lana Perić 


\section{TABLE OF CONTENTS}

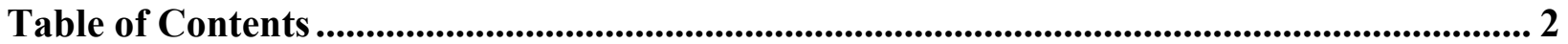

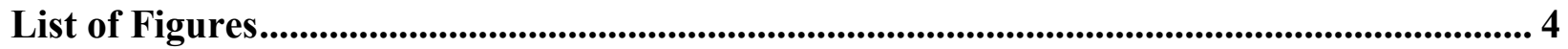

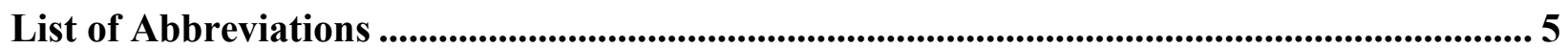

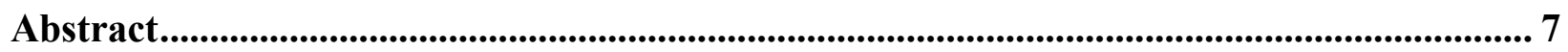

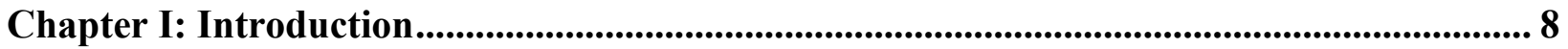

A. Introduction to the Research Issue and the Research Question......................................................8

B. Research Outline ............................................................................................................................................. 16

c. Scope of the Project …..................................................................................................................................... 17

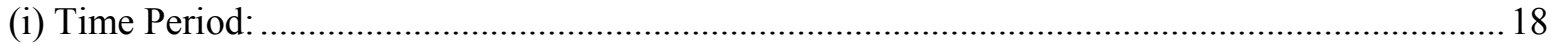

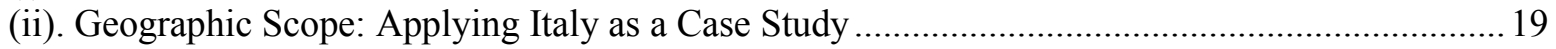

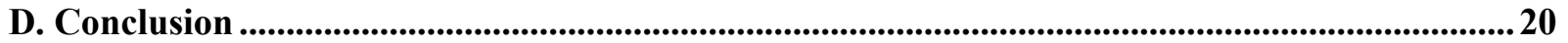

Chapter II: Methodology ............................................................................................................. 23

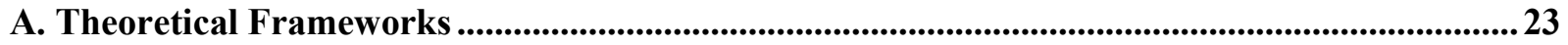

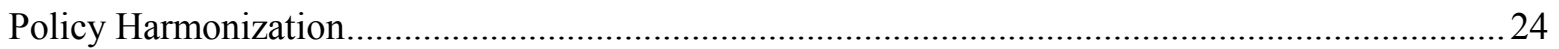

Deterrence Theory and Reintegrative Shaming Theory: Crossing International Relations with

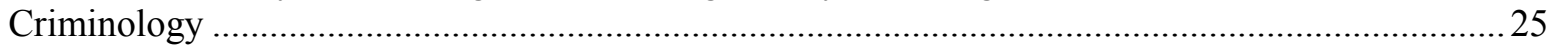

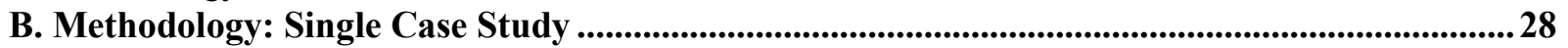

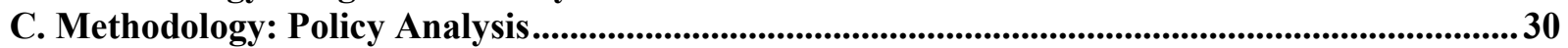

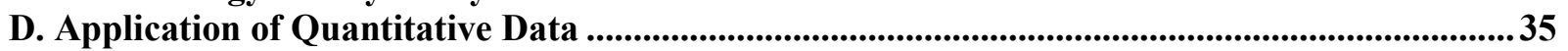

Chapter III: Literature Review ....................................................................................................... 36

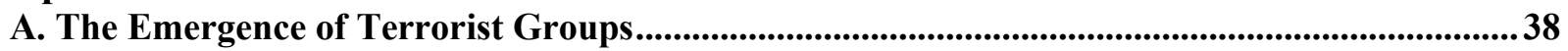

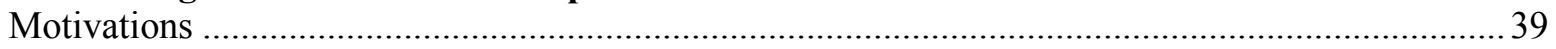

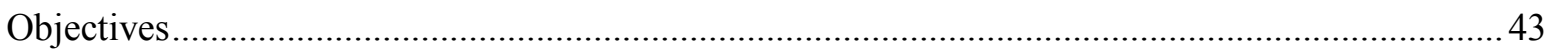

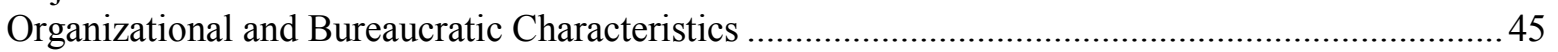

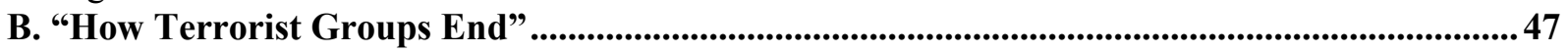

C. Evaluation of the Effectiveness of Counterterrorism Policies and Strategies .............................50

Chapter IV: The EU and Counterterrorism ................................................................ 55

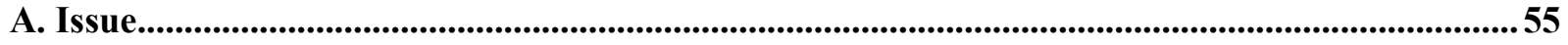

B. Background on Terrorism and Jihadist Extremism in Western Europe/the EU.......................57

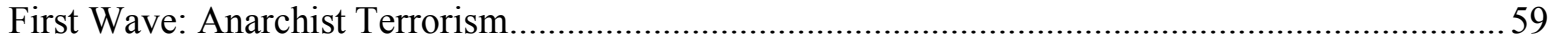

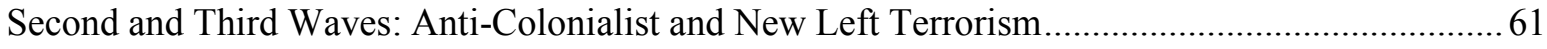

Fourth Wave: Religious Wave and the Spread of Jihadist Extremists in Europe ............................... 64

C. Europeanization: A Single European Intelligence Agency ..............................................................74

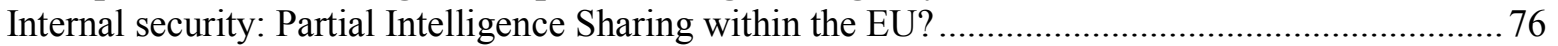

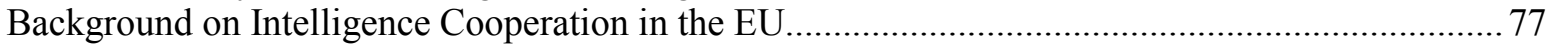

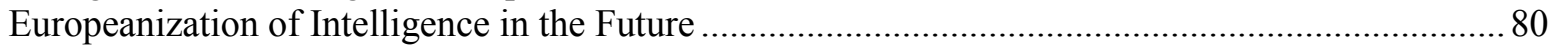

D. Policy Analysis: Findings and Discussion .....................................................................................8 83

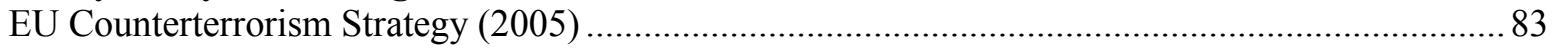

General Trends Derived from the Policy Analysis of the EU's Counterterrorism Measures

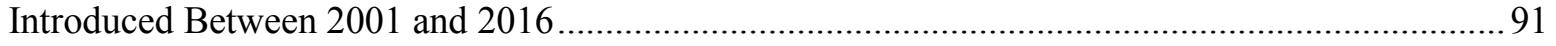

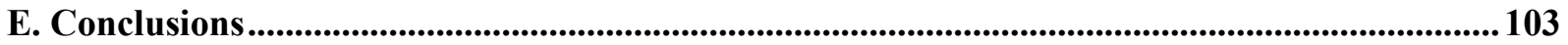


Chapter V: Italy's Counterterrorism Measures ............................................................ 105

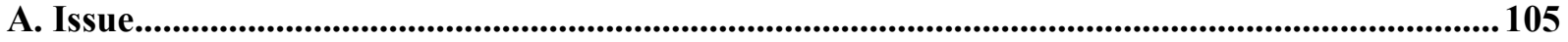

B. Background on Terrorism and Jihadist Extremism in Italy ...............................................105

The Years of Lead: Political terrorism in Italy from 1969-1989 ............................................... 106

Italy's Complicated Relationship with its Muslim Community .................................................. 110

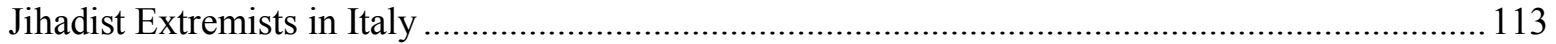

C. General Overview of Qualitative Analysis of Italy's Counterterrorism Measures (2001-2016)

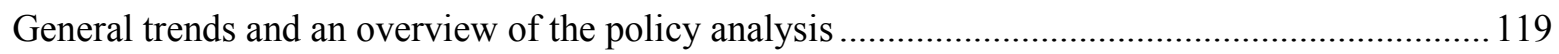

D. Findings and Discussion ........................................................................................................................ 127

Options for Those Convicted of Terrorism Offences - Deportation or Collaboration .................... 127

Merging Anti-Mafia Measures with Anti-Terrorism: Preventative and Deterrent Measures .......... 134

Holistic Deterrent Approaches: Collaboration, Reintegration, and Prison Reforms...................... 138

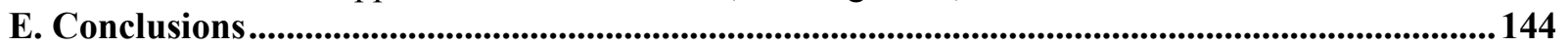

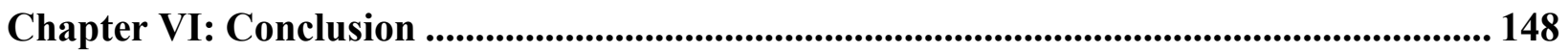

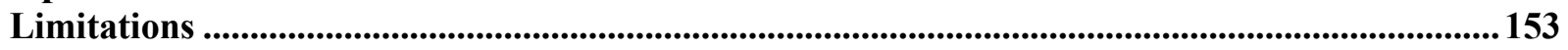

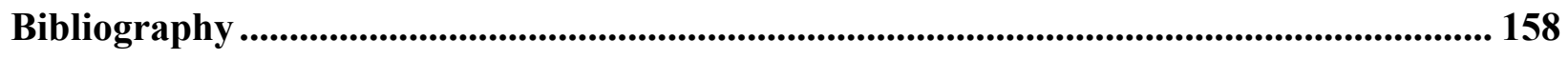

Annex A: List of Measures Examined ...................................................................... 175

EU Measures …................................................................................................................................... 175

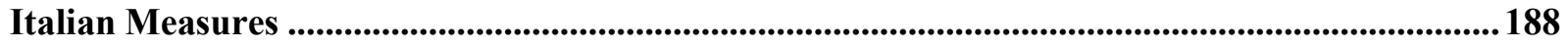

Annex B: Pillars of the EU Counterterrorism Strategy 2005 ............................................... 198

Annex C: Council Framework Decision 2002/475/JHA On Combatting Terrorism ......... 199 
Figure 4.1 Total Attacks in the EU between 1970 and 2000

Figure 4.2 Total Attacks in the EU between 2001 and 2015

Figure 4.3 EU Counterterrorism Competencies

Figure 4.4 Pillars of the EU Counterterrorism Strategy (2005) 84

Figure 4.5 Number of Counterterrorism Measures Passed by EU Institutions between

92 2001 and 2016

Figure 4.6 Total Number of Terrorist Attacks in the EU between 2001 and 2015

92

Figure 4.7 Total Number of Successful Terrorist Attacks in the EU between 2001 and 93 2015

Figure 4.8 Evaluated Counterterrorism Measures Categorized Under the EU Counterterrorism Strategy's Pillars

Figure 4.9 Themes of the EU's Counterterrorism Measures

Figure 5.1 Counterterrorism Strategy Pillars applicable to Italian counterterrorism measures

Figure 5.2 Application of the EU definition of "terrorism" in Italian counterterrorism measures

Figure 5.3 Italian counterterrorism measures harmonized with EU law

Figure 5.4 Themes of Italian Counterterrorism measures

Figure 5.5. Foreign citizens deported from Italy for reasons of security, 2002-31 Oct 2017 


\section{LIST OF ABBREVIATIONS}

al-Gama'a al-Islamyya

Central Intelligence Agency

Chemical, biological, radiological, and nuclear material

Common Foreign and Security Policy

Common Security and Defence Policy

Counter-insurgency

Countering violent extremism

Emergency Response Coordination Centre

EU Joint Situation Centre/Intelligence Analysis Centre

EU Military Committee

EU Military Staff

European Community

European Convention on Human Rights

European Court of Human Rights

European Drug Unit

European External Action Services

European Police Office

European Union

European Union Terrorism Situation and Trend Report

Euskadi Ta Askatasuna (English: Basque Homeland and Liberty)

Five Eyes [Alliance]

Foreign fighter

High Representative of the Union for Foreign Affairs and

Security/Vice-President of the Commission

Human intelligence

Imagery intelligence

International Centre for Counter-Terrorism

Irish Revolutionary Army

Istituto Culturale Islamico Milano (English: the Islamic Cultural Institution in Milan)

Member State

Muslim Brotherhood

North Atlantic Treaty Organization

Open source intelligence

Passenger Name Records
GI

CIA

CBRN

CFSP

CSDP

COIN

CVE

ERCC

SITCEN/INTCEN

EUMC

EUMS

EC

ECHR

ECtHR

EDU

EEAS

Europol

EU

TE-SAT

ETA

FVEY

FF

HR/VP

HUMINT

IMINT

ICCT

IRA

ICIM

MS

MB

NATO

OSINT

PNR 
Political and Security Committee PSC

Red Army Faction $\quad$ RAF

Servizio Informazioni Difesa (English: Defence Intelligence

Service)

SID

Servizio informazioni sicurezza democratica (English: Democratic Security Intelligence Service)

SISDE

Signals intelligence

SIGINT

Smart, Measurable, Achievable/Attainable, Realistic/Relevant,

Time-bound

SMART

Terrorism, Radicalism, Extremism, Violence International Group TREVI

Treaty of the European Union

TEU

Treaty of the Functioning of the European Union

TFEU

United Kingdom

UK

United Nations

$\mathrm{UN}$

United States of America

US

Usama Bin Laden

UBL 
In the last few years, Europe has experienced a surge of terrorist attacks perpetrated by jihadist extremists that were either external operators of Daesh (a.k.a. the Islamic State [IS], the Islamic State of Iraq and the Levant [ISIL], or the Islamic State of Iraq and Syria/al-Sham [ISIS]) or they were simply inspired by Daesh. Despite the focus on these attacks by the governments and media, Europe is no stranger to terrorism. The continent has experienced four waves of terrorism that witnessed a dominant extremist threat in each wave. As the European Union (EU) aims to deepen their integration in the realm of foreign, security, and defence policies, the Union and its institutions have developed counterterrorism measures that fall under a framework of four distinct pillars: PREVENT, PROTECT, PURSUE, and RESPOND. With Europe's long history of terrorism, it is expected that the Union would apply lessons learned from previous cases. If this is the case, the large number of measures passed by the EU should be effective in disrupting the terrorist threat across its member states. However, the threat continues to persist and the Union and its member states continue to develop reactionary measures that utilize mass amounts of resources, rather than focusing on preventative and deterrent measures. This thesis sets out to determine why the EU's counterterrorism measures are ineffective by conducting a qualitative policy analysis of the EU's binding counterterrorism measures. This thesis applies a single-case study by examining counterterrorism measures in Italy, a EU member state that has not experienced jihadist extremism in the same concentration as other Western EU member states. The following research aims to identify where Italian measures differ from the EU's measures, and whether the EU can learn from Italy's historical experiences with counterterrorism and countering organized crime. 


\section{CHAPTER I: INTRODUCTION}

"Let us remember that their goal is to terrorize. Don't let them win. Do not be afraid. Do not go back on your values. We should mourn, but we should move on to show them we're not going to give up."

- Anonymous French citizen following the November 2015 attacks in Paris, France

"1. The revolutionary is a doomed man. He has no personal interests, no business affairs, no emotions, no attachments, no property, and no name. Everything in him is wholly absorbed in the single thought and the single passion for revolution." - Sergey Nechayev in The Duties of the Revolutionary Toward Himself, the Revolutionary Catechism (1876)

\section{A. INTRODUCTION TO THE RESEARCH ISSUE AND THE RESEARCH QUESTION}

European involvement in counter-terrorism initiatives has been gradually evolving since the turn of the millennium to parallel the changing threats posed by extremists. European member states, particularly those in the West, tackled their fair share of left-wing extremists in the second half of the twentieth century. ${ }^{1}$ With the $9 / 11$ attacks on the World Trade Centre and the Pentagon, perpetrated by jihadist extremists ${ }^{2}$, the way terrorism was perceived began to shift significantly due to several factors. One, the evolution of terrorism occurred alongside the rise of globalization, therefore the threat of terrorism was not only a domestic issue that had to be dealt with by a single state, it transgressed borders and had to be addressed as such. This manifested itself in the "global jihadist movement" resulting in groups and movements affiliated with, and

\footnotetext{
${ }^{1}$ The Global Terrorist Database (GTB) provides statistics on 170000 terrorist attacks around the world between 1970 and 2016. The GTB illustrates that terrorist incidents only began to arise since 1988 and averaging at around 200 incidents a year, whereas terrorism has been prominent in Western Europe since the beginnings of the dataset provided. In 1979, Western Europe experienced approximately 1000 incidents of terrorism.

${ }^{2}$ Jihadist extremists refer to radicalized individuals using Islam as an ideological and/or religious justification for their belief in the establishment of a global caliphate, or jurisdiction governed by a Muslim civil and religious leader known as a caliph. Many "jihadist extremists" are not necessarily "violent extremists" because they may be dormant, but their support for the ideology promotes its proliferation and the individual may act in "non-violent" ways to support jihadist extremist groups, such as spreading propaganda, financing, or facilitating the movement of foreign fighters and recruits. (Source: Jerome P. Bjelopera, "American Jihadist Terrorism: Combatting a Complex Threat," Congressional Research Service, January 2013, 1-2.)
} 
inspired by, larger terrorist organizations such as Al Qaeda. ${ }^{3}$ Second, attacks were perpetrated and coordinated by members belonging to large networks that were not aligned with any state in particular. ${ }^{4}$ Therefore, the question that puzzled policymakers and academics alike was how do states deal with an adversary that cannot be contained? A third factor was the motivations that inspired the deadliest attacks - Western Europe had dealt with left-wing and right-wing extremists, but the new threat derived from religious extremism, particularly by jihadists. The attacks in Madrid and London (11 March 2004 and 7 July 2005, respectively) also served as factors that altered the way that the European Union (EU) and its member states tackled terrorism. $^{5}$

Despite the coordinated efforts to combat terrorism at the EU level, the EU's counterterrorism measures are fragmented and sporadic at best, with a large majority of the measures comprising of non-binding laws (proposals, recommendations, action plans). This means that member states are not required to implement a large portion of the EU's counterterrorism measures, thus preventing the Union from approaching the threat with a unified front. This will become particularly problematic in the near future, as Daesh's ${ }^{6}$ so-called Caliphate (which was established in June 2014) rapidly loses territory across Syria and Iraq, resulting in an exodus of foreign fighters returning to their "home" countries in Europe. The EU has situated the jihadist extremist threat to take place externally from Europe, but with the threat

\footnotetext{
${ }^{3}$ Lauren O’Brien, “The Evolution of Terrorism Since 9/11," Law Enforcement Bulletin - Federal Bureau of Investigations, 2011 ; Neal A. Pollard, "Globalization's Bastards: Illegitimate Non-State Actors," in International Law, Low Intensity Conflict \& Law Enforcement 11 no.2-3 (2002): 213-214.

${ }^{4}$ Neal A. Pollard, "Globalization's Bastards: Illegitimate Non-State Actors," in International Law, Low Intensity Conflict \& Law Enforcement 11:2-3(2002): 215.

${ }^{5}$ Doron Zimmermann, "The European Union and Post-9/11 Counterterrorism: A Reappraisal," in Studies in Conflict \& Terrorism 29 no.2 (2006): 139.

${ }^{6}$ Also known as the Islamic State of Iraq and the Levant (ISIL), the Islamic State of Iraq and Syria (ISIS), and the Islamic State (IS). Although these three versions are applied widely, this paper will refer to the terrorist organization as Daesh in order to distance the Islamic religion from the terrorist operations conducted by Daesh. Additionally, the word "Daesh" is essentially an Arabic acronym formed from the initial letters of the group's previous name in Arabic - "al-Dawla al-Islamiya fil Iraq wa alSham". Although it does not mean anything as a word in Arabic, it sounds unpleasant and the group's supporters object to its use. Daesh also sounds similar to an Arabic verb that means to tread underfoot, trample down, or crush something.
} 
coming home. Moreover, the return of many fighters will likely result in a rise in cells establishing themselves as part of a network across the EU. This will likely also lead to recruitment efforts at home and a rise in propaganda that continues to push for attacks in the EU. The fall of Daesh strongholds across Syria and Iraq in 2017 has left foreign fighters without their so-called Caliphate to serve as their headquarters, and Western states are currently debating what to anticipate from Daesh and how to move forward with the dispersal and return of foreign fighters. $^{7}$ Governments are anticipating the influx of returning foreign fighters based on historical cases of foreign fighting in Afghanistan (1980s), Bosnia (1990s), and Somalia (2000s). ${ }^{8}$ However, radicalization is not a new phenomenon for Europe, as many countries have experienced their fair share of terrorism, particularly since the late $19^{\text {th }}$ century.

Europe's unique experiences with extremism and terrorism lead this thesis to explore Europe's counterterrorism measures. As such, the question that my thesis aims to answer is why are the counterterrorism measures of the EU ineffective? The hypotheses for this question state the following:

- Hypothesis A: The EU's counterterrorism policies are ineffective because member states have not harmonized their counterterrorism policies with the EU's policies; and,

- Hypothesis B: The EU's counterterrorism policies are ineffective because the EU's counterterrorism measures fail to address the PREVENT pillar of the EU's counterterrorism Strategy.

Hypothesis A will be supported by applying a single case study of a EU member state that has not experienced jihadist terrorist attacks to the same degree as other western EU member

\footnotetext{
${ }^{7}$ Alaistar Reed and Johanna Pohl, "Tackling the surge of returning foreign fighters," NATO Review Magazine, July 2017: https://www.nato.int/docu/review/2017/Also-in-2017/daesh-tackling-surge-returning-foreign-fighters-prevention-denmarkrehabilitation-programmes/EN/index.htm.

${ }^{8}$ Jeanine de Roy van Zuijdewijn and Edwin Bakker, "Returning Western foreign fighters: The case of Afghanistan, Bosnia and Somalia," Background note for the International Centre for Counter-terrorism - The Hague, June 2014.
} 
states; the thesis will find that the case study, Italy, enforces counterterrorism measures that do not follow the EU's so-called norms for counterterrorism; thus, this will exemplify how the difference in measures is one factor to consider when examining the different results of counterterrorism. Hypothesis B will be supported by quantitatively illustrating the lack of preventative counterterrorism measures enacted by the EU and how the existing measures could follow Italy's model of deterrence theory vis-à-vis the reintegrative shaming strategy.

Two main theoretical frameworks are applied in this thesis to analyze the effectiveness of the EU's counterterrorism measures: first, by modelling its approaches after Italian counterterrorism measures, which have roots in deterrence theory; and second, by ensuring counterterrorism measures are harmonized across the Union by starting with a fully integrated European security agency. This thesis will examine how deterrence theory is applicable to Italy's counterterrorism measures and why Italy has had more success in the realm of counterterrorism compared to other [western] EU member states. With that in mind, in addition to a theoretical framework that applies deterrence theory and theories on policy harmonization, this thesis also employs a high-level qualitative comparative approach analyzing Italy's counterterrorism measures compared to the EU's existing measures. Due to time and space constraints, this thesis will only examine the primary legislative and strategic documents aimed at combatting contemporary terrorism, which have been drafted since the 9/11 attacks (see Annex A which outlines the documents examined for the purpose of this thesis). The purpose of this thesis is to build on the literature regarding the use of deterrence theory for combatting contemporary terrorism, and particularly for the purpose of policy development that will hopefully produce effective European counterterrorism measures that interrogates a new understanding of deterrence theory. 
As this thesis discusses the question of "effectiveness", it is necessary to first outline the definition used in this thesis. This thesis defines "effectiveness" as successfully obtaining and accomplishing an objective; within the realm of counterterrorism, it can be operationalized as:

- The eradication of the terrorist threat by preventing or disrupting a plotted attack and the flow of resources (where resources include humans, finances, and/or material goods necessary for the plot);

- The disruption and/or dismantling of a network and its activities (which can include external operations, facilitation, and/or production and proliferation of media); and,

- Preventing individuals from joining extremist organizations and becoming a threat to the state.

This thesis does occasionally describe a measure as "effective" and "efficient", but these terms are not interchangeable. While some measures may be effective in terms of achieving their desired result, they may not be efficient. Efficient measures apply resources (human and monetary) proportionally and focuses on the process, whereas effectiveness focuses on the end goal.

It is also necessary to draw attention to a premise of the research question, as it establishes a baseline assumption that declares that the EU's counterterrorism policies and frameworks are ineffective. This assumption is based on the following eight factors that demonstrate a lack of effectiveness in the EU's attempts to combat terrorism:

\begin{tabular}{|l|l|}
\hline $\begin{array}{l}\text { 1. Lack of political } \\
\text { integration }\end{array}$ & $\begin{array}{l}\text { The EU has been unable to achieve a level of political integration that allows } \\
\text { for a single foreign, security, and defense policy. All EU activities that pertain } \\
\text { to the Common Foreign and Security Policy (CFSP) and Common Security and }\end{array}$ \\
\hline
\end{tabular}




\begin{tabular}{|c|c|}
\hline & $\begin{array}{l}\text { Defence Policy (CSDP) are conducted in an intergovernmental manner because } \\
\text { of the sensitivities associated with transferring national security powers over to } \\
\text { the EU. Despite the open borders and freedom of movement, member states } \\
\text { prefer to have power over their own national security concerns. }\end{array}$ \\
\hline $\begin{array}{l}\text { 2. Absence of } \\
\text { cohesive } \mathbf{E U} \\
\text { intelligence agency }\end{array}$ & $\begin{array}{l}\text { As a result, there is no single, cohesive intelligence agency for the EU that } \\
\text { involves member states sharing intelligence on terrorism. Partial intelligence } \\
\text { cooperation has been achieved through the creation of institutions such as the } \\
\text { EU Joint Situation Centre, the EU Military Staff (which has intelligence } \\
\text { capabilities), and the original establishment of the TREVI Group. However, } \\
\text { member states are reluctant about sharing intelligence despite the fact that } \\
\text { intelligence-sharing with regards to terrorism often signals more cooperation. }\end{array}$ \\
\hline $\begin{array}{l}\text { 3. Absence of } \mathbf{E U} \\
\text { intelligence sharing } \\
\text { coupled with open } \\
\text { borders }\end{array}$ & $\begin{array}{l}\text { The lack of intelligence sharing in matters related to counterterrorism and } \\
\text { terrorism, in addition to the open Schengen borders, is a combination that is } \\
\text { allowing for Daesh sleeper cells to develop. }\end{array}$ \\
\hline $\begin{array}{l}\text { 4. Security/CT } \\
\text { strategies are not } \\
\text { frequently reviewed } \\
\text { for amendments }\end{array}$ & $\begin{array}{l}\text { Although the European Security Strategy of } 2003 \text { has finally undergone } \\
\text { amendments in June 2016, the EU's Counterterrorism Strategy remains } \\
\text { untouched since 2005. Without updating the EU's counterterrorism strategy, } \\
\text { the rapid developments of terrorism and terrorist networks are not taken into } \\
\text { account. Additionally, this makes it difficult for the harmonization of } \\
\text { counterterrorism policies and strategies. Member states are more inclined to } \\
\text { make their own amendment to counterterrorism measures, particularly in the }\end{array}$ \\
\hline
\end{tabular}

\footnotetext{
${ }^{9}$ Kroet, Cynthia. “Europe's open borders allow ISIL sleeper cells: US intelligence chief.” Politico. Published on 27 April 2016. http://www.politico.eu/article/europes-open-borders-allow-isil-sleeper-cells-us-intelligence-chief/
} 


\begin{tabular}{|c|c|}
\hline & wake of terrorist threats, \\
\hline $\begin{array}{l}\text { 5. Frequency of } \\
\text { prominent attacks } \\
\text { in Western Europe }\end{array}$ & $\begin{array}{l}\text { Several profound terrorist attacks have occurred since } 2015 \text { throughout the } \\
\text { EU. }{ }^{10} \text { In addition to the increasing frequency of large-scale attacks, there was } \\
\text { an overlap of perpetrators in both of these attacks (e.g. Mohamed Abrini }{ }^{11} \text { ) and } \\
\text { dozens of individuals have been unveiled for having a connection to the large } \\
\text { terrorist network that was responsible for the Paris and Brussels attacks. }{ }^{12} \text { This } \\
\text { implies that more than one EU member state has undergone failed attempts to } \\
\text { detain numerous individuals linked to a transnational terrorist network. }{ }^{13}\end{array}$ \\
\hline $\begin{array}{l}\text { 6. Late policy } \\
\text { responses }\end{array}$ & $\begin{array}{l}\text { The policy responses following large-scale terrorist incidents occur within } \\
\text { weeks after an attack, when they should have been implemented earlier on. For } \\
\text { example, Belgium has been "expecting" a large-scale attack since the murder of } \\
\text { four people outside a Jewish museum in Brussels on } 24 \text { May } 2014^{14} \text {, and the } \\
\text { country has been steadily increasing the size of their security services since } \\
\text { then. Following the two Paris attacks, there has been an expansion of } \\
\text { Belgium's security services. }\end{array}$ \\
\hline 7. Concluded & Paris and Brussels attacks occurred soon after European MS officials have \\
\hline
\end{tabular}

\footnotetext{
${ }^{10}$ Lethal attacks included the Paris attacks in November 2015, Brussels in March 2016, Nice in July 2016, Berlin in December 2016, Manchester in May 2017, London in March and June 2017, and Barcelone in August 2017.

${ }^{11}$ Mohamed Abrini is a Belgian national of Moroccan descent who is alleged to have been involved in the planning and execution of the November 2015 Paris attacks and the 2016 Brussels bombings.

${ }^{12}$ Miller, Greg and Joby Warrick. "How Belgium became the hub of terror within Europe." The Washington Times. Published on 22 March 2016. https://www.washingtonpost.com/world/national-security/how-belgium-became-the-hub-of-terrorism-ineurope/2016/03/22/9b729164-f042-11e5-a61f-e9c95c06edca story.html

${ }^{13}$ Nesser, Petter and Anne Stenersen. "The Modus Operandi of Jihadist Terrorists in Europe." Perspectives on Terrorism 8:6 (2014). http://www.terrorismanalysts.com/pt/index.php/pot/article/view/388/html

${ }^{14}$ Penkenth, Anne. "Brussels Jewish Museum shooting: suspect with Islamist links arrested." The Guardian. Published on 1 June 2014. http://www.theguardian.com/world/2014/jun/01/suspect-arrest-brussels-jewish-museum-shooting

${ }^{15}$ Blitz, James. "Hard questions for Belgium's security services.” Financial Times. Published on 23 March 2016. http://www.ft.com/cms/s/0/ba92eb42-f101-11e5-aff5-19b4e253664a.html\#axzz47CAzmCCq
} 


\begin{tabular}{|c|c|}
\hline $\begin{array}{l}\text { operations fail to } \\
\text { cease large attacks }\end{array}$ & $\begin{array}{l}\text { conducted terrorist raids. } \\
\text { - Operation JWEB was concluded a day before the Paris attacks in } \\
\text { - Belgian counterterrorism operations, in which terrorist suspect Salah } \\
\text { Abdeslam was detained, were conducted the week prior to the March } \\
2016 \text { attacks in Brussels. }{ }^{17}\end{array}$ \\
\hline $\begin{array}{l}\text { 8. Large number of } \\
\text { foreign fighters } \\
\text { originating from } \\
\text { Western Europe }\end{array}$ & $\begin{array}{l}\text { Western European states are producing the highest numbers of foreign fighters } \\
\text { that are leaving Europe for Iraq and Syria. France has produced the largest } \\
\text { number of foreign fighters, while Belgium has the highest number of foreign } \\
\text { fighters per capita. }{ }^{18}\end{array}$ \\
\hline
\end{tabular}

The research question is important in the sense that it needs to be considered within the context of national and multilateral counterterrorism strategies in order to determine where the policy and strategic gaps exist. By concluding where strategies differ, it will be useful to establish the most "effective" anti-terrorism strategies. Although it is difficult to determine what it means to have an "effective" counterterrorism strategy, partially due to the lack of agreement on counterterrorism effectiveness, further qualitative analyses can produce some criteria that can be applied in various cases to determine counterterrorism effectiveness. The preliminary methodology that operationalizes counterterrorism effectiveness will be explored in the subsequent sections of this paper.

Above all, the importance of this topic stems from the fact that international terrorism is

\footnotetext{
${ }^{16}$ Paravicini, Giulia. "Busted jihadist network plotted to snatch diplomats.” Politico. Published on 12 November 2015.

http://www.politico.eu/article/europe-police-dismantle-major-jihadist-network-krekar/

${ }^{17}$ Botelho, Greg. "Salah Abdeslam, Paris terror suspect, captured; four others arrested." CNN. Published on 18 March 2016. http:/www.cnn.com/2016/03/18/world/paris-attack-salah-abdeslam-fingerprints-capture/

${ }^{18}$ Neumann, Peter R. "Foreign fighter total in Syria/Iraq now exceeds 20,000; surpasses Afghanistan conflict in the 1980s." International Centre for The Study Of Radicalisation And Political Violence. Published on 26 January 2015. http://icsr.info/2015/01/foreign-fighter-total-syriairaq-now-exceeds-20000-surpasses-afghanistan-conflict-1980s/; --. "Foreign fighters in Iraq and Syria: Where do they come from?” Radio Free Europe/Radio Liberty. Updated on 28 April 2016. http://www.rferl.org/contentinfographics/foreign-fighters-syria-iraq-is-isis-isil-infographic/26584940.html
} 
one of the very few security threats that unites governments against a common adversary because of its universal effects. However, if governments intend on cooperating with one another, there needs to be more consistency in tackling radicalization and protecting against terrorist attacks. The EU provides an interesting and important backdrop for this problem for at least two reasons: first, since member states are part of an "ever closer union", effective cooperation is far more likely to occur, despite the slow progress in political integration (vis-à-vis the CFSP and the CSDP); secondly, Western Europe has been experiencing a drastic increase of radicalized individuals who are either generating domestic threats, or going abroad to Daesh-controlled territories to serve as foreign fighters. This new trend demonstrates that there must be a flaw in counterterrorism policies and strategies oriented toward preventative measures, therefore the prospective research will place an emphasis on prevention. These issues of research relevancy will be addressed more closely in the subsequent section of this thesis, which examines the scope of the prospective thesis and the case studies that will be examined.

\section{B. RESEARCH OUTLINE}

The following chapter will begin with introducing the theoretical frameworks used for this thesis, which consists of deterrence theory and policy harmonization, followed by how documents were selected for analysis. During the elaborating on deterrence theory, the methodology chapter will highlight some key points of classical deterrence theory, which came about during the Cold War, and how it has evolved in the post-9/11 context. The chapter will also demonstrate how deterrence theory should not be limited to the classical understanding based off of the discipline of international relations, as a criminological understanding of deterrence theory can help policymakers develop more effective counterterrorism measures. 
Afterward, the literature review will be included to build a foundation for this paper's argument and hypotheses. The literature review examines the existing literature on counterterrorism effectiveness and understanding terrorism at the individual, group, and organizational levels. This is necessary to establish how a rational actor model is applicable and feeds into the logic of deterrence in the context of contemporary counterterrorism.

Once a basis has been built from the methodology and literature review, this thesis will begin by analyzing the EU case. Within the EU case study, this thesis will conduct a policy analysis on the selected documents to outline the ineffectiveness of the EU's counterterrorism measures. Similar to the Italian case study, the European case study will begin by highlighting the EU's history with terrorism, and specifically jihadist terrorism. The policy analysis will focus on exploring the trends and the gaps identified in the EU's counterterrorism measures. Moreover, this thesis will also aim to explain how deterrence theory can also be used to improve the EU's preventative strategies for combatting terrorism.

Finally, the Italian case study will be presented. This case study contains a sub argument declaring that Italian counterterrorism is effective because deterrence theory is an applicable strategic guide to Italy's counterterrorism measures, based on the country's experience with political terrorism in the $20^{\text {th }}$ century and its persistent experience with organized crime. This chapter will look at Italy's background with its experience with political terrorism, and more recently, jihadist terrorism. The background will provide context to Italy's counterterrorism measures, which will subsequently be analyzed to determine where Italy differs from the overarching EU approaches to counterterrorism and which measures have produced effective results. 
(i) Time Period:

The scholarship on terrorism studies and counterterrorism has been exhausted in numerous directions, and additionally, it is a broad and contentious subject. For these reasons, this thesis has been oriented in a specific direction that allows for original research outcomes to develop. First, as various forms of terrorism date back centuries in Europe, it is necessary to select a specific time period to narrow down the research and to understand the subject matter within the context of the domestic and international events occurring at the time. The time period that will be examined for my research period will be 2001 through 2016 , due to the shift in modus operandi that pertain to terrorism. This shift was marked with several multilateral strategies produced by the EU in the early-to-mid-2000s, particularly the EU Security Strategy of 2003 and the EU's Counter-Terrorism Strategy of 2005 (which was developed in conjunction with the United Nations' [UN] 2005 Global Counter-Terrorism Strategy; see Annex B for a chart explaining the main pillars of the EU's counterterrorism strategy). The research will go on to analyze relevant material produced up until June 2016 because of a new "Global Strategy" prepared by the High Representative Federica Morgherini, which was presented by the EU's leaders in June $2016 .{ }^{19}$ Depending on the measures produced by this strategy and how well it will be implemented by member states, it can result in interesting patterns for future research.

Additionally, the time frame for my research allows for the investigation of Daesh-related events, which includes the 2015 terrorist attacks in Paris (7 January and 13 November) and the 2016 attack in Brussels (22 March). In recent years, there has also been a shift in radicalization trends, which now tends to include young Islamic extremists that have grown up in Western

\footnotetext{
${ }^{19}$ European External Action Services. "Global Strategy to steer EU external action in an increasingly connected, contested and complex world." Published on 30 June 2015. Accessed on 13 February 2016. 
Europe with immigrant families or who have converted to Islam themselves. The last fifteen years also serve as an interesting time period because it demonstrates the increasing role social media has had in open-source intelligence (OSINT) gathering for the purposes of counterterrorism, and how social media has played a role in radicalization.

(ii). Geographic Scope: Applying Italy as a Case Study

Although the EU will ultimately be examined from the macro-level, the prospective research will evaluate Italy as a case study in order to determine why Italy has seen a different trajectory in jihadist extremism compared to other EU countries, namely those in Western Europe. Below I will first outline the reasons for selecting Italy as an individual case study.

Italy presents an interesting case when discussing counterterrorism strategy because of their preemptive and rehabilitative counterterrorism measures (which are explored in Chapter V) and their positive track record of disrupting large-scale terrorist attacks by Islamic extremists on Italian soil, despite being targeted and threatened on numerous occasions since Daesh established their caliphate in June $2014 .{ }^{20}$ Italy is being used as a case study for several reasons pertaining to their offensive, yet preventative, approaches and capabilities: their history of dealing with political terrorism (Italy was particularly affected during the 1970s); Italy's use of its deterrence theory vis-à-vis the reintegrative shaming strategy, demonstrating how deterrence theory can be applied to counterterrorism beyond an approach that involves neutralizing the senior leadership of terrorist organizations; and because Italy has a unique method of approaching terrorism by combining their anti-mafia and anti-terrorism measures. As this thesis focuses on jihadist

\footnotetext{
${ }^{20}$ Christopher Livesay, "Rome is Not Intimidated by ISIS Threats to Conquer it for the Caliphate," Vice News, 11 July 2014, https://news.vice.com/article/rome-is-not-intimidated-by-isis-threats-to-conquer-it-for-the-caliphate ; Gianluca Rini, "Terrorismo in Italia: tutte le minacce dell'Isis" (English: "Terrorism in Italy: All of the ISIS Threats [Against Italy]"), Nano Press, 22 January 2016, http://www.nanopress.it/cronaca/2016/01/22/terrorismo-in-italia-tutte-le-minacce-dell-isis/47271/ ; --, "L'Isis ha minacciato du nuovo l'Italia, dobbiamo preoccuparici?" (English: "ISIS has threatened Italy again, should we be worried?"), Il Post, 21 August 2017, http://www.ilpost.it/2017/08/21/isis-minacce-italia-attentati/.
} 
extremism, Italy's unique relationship with its Muslim community will also be highlighted, in addition to the country's history with jihadist networks operating logistics from cells within northern Italy. ${ }^{21}$

While it can be assumed that the counterterrorism strategies of the EU's member states are similar in scope and reflect the EU's counterterrorism strategy of 2005, within this thesis I explore where the gaps exist between Italy and the EU, thus make inference that the EU member states are not acting uniformly in counterterrorism. This thesis does not necessarily compare the Italian and European counterterrorism models and measures, but the use of Italy as a case study serves two purposes to support this research's' hypotheses. First, this thesis examines whether Italy adopts and implements measures derived from the EU's Counterterrorism Strategy, and if so, to what extent are these measures implemented into national legislation; and second, this thesis will examine how Italy's counterterrorism model has diverged from the EU's standards in order to accomplish effective results, and whether these Italian measures can be leveraged by the EU and its member states to produce similar results.

Ultimately, the hopes for the outcome of this research is that the established policies and strategies can be applied throughout the rest of the EU.

\section{CONCLUSION}

\footnotetext{
${ }^{21}$ Luttwak, Edward N. "Italy has lessons to teach in counter-terrorism." Nikkei Asian Review. Published on 17 December 2015. Accessed on 17 February 2016. http://asia.nikkei.com/magazine/20151217-ASEAN-ECONOMIC-COMMUNITY-REALITYCHECK/Viewpoints/Edward-N.-Luttwak-Italy-has-lessons-to-teach-in-counterterrorism
} 
Throughout my analytical research of Italy's counterterrorism measures in comparison to the EU's, I seek to support my hypotheses that the EU's counterterrorism policies are ineffective because (a) member states have not harmonized their counterterrorism policies with the EU's policies, and (b) because the existing measures fail to address the PREVENT pillar of the EU's Counterterrorism Strategy and the measures lack strategic guidance.

Terrorism studies, and with the particular emphasis on counterterrorism, require multifaceted and interdisciplinary approach, which is reflected in this thesis. Beyond the integration of political science, international relations, and EU studies, this thesis also requires applying aspects of criminology, psychology, sociology, and policy studies. It is fundamental to understand terrorism from these various levels as the various characteristics of all of these disciplines are thoroughly embedded into the problem of the terrorism phenomena.

The following methodology section will provide the two theoretical frameworks applied to this research. First, policy harmonization will be examined to explain how it contributes to the process of deeper European integration, which this thesis ultimately argues for, as the research concludes that a harmonized counterterrorism approach is required throughout the Union in order to produce effective results in counterterrorism. Moreover, this thesis also argues for a single European intelligence agency to aid counterterrorism efforts. Additionally, internal harmonization would also be beneficial to the EU because of their struggle to create a "single European army" and a cohesive defence policy (one that goes beyond civilian and peacekeeping missions that serve to demonstrate the EU's normative power). Focusing on the internal security architectures of the EU would be more beneficial, while attempting to get the EU member states on the same page regarding intelligence sharing. 
The second theoretical framework examined is deterrence theory. Deterrence theory is often examined from an international relations perspective and applied to explain the behavior of states with nuclear arsenals, but these strategies can be thought of as practical applications of different theories of crime deterrence. When deterrence theory is applied to terrorism studies, it is often in the context of targeted killings to deter members of terrorist organizations from pursuing to carry out terrorist activities. ${ }^{22}$ While there are two major deterrent strategies that can be applied in the criminological context (denial strategy and reintegrative shaming strategy), this thesis explains why the reintegrative shaming strategy would be more effective for counterterrorism, based on the experience of Italy.

This thesis will also stress the lack of attention paid toward the sociological and psychological aspects of terrorism. The EU's counterterrorism measures neglect the psychology of the terrorist, which is exemplified by their lack of acknowledgement of different "types" of terrorism (meaning, the various ideologies that play a role in extremism) and the various objectives and agendas by different terrorism organizations. All in all, the different components of terrorism studies and the theoretical frameworks applied to the research, in conjunction with the policy analysis, aim to show that the EU's counterterrorism measures are ineffective.

${ }^{22}$ Alex Wilner. Deterring Rational Fanatics. Pennsylvania: University of Pennsylvania Press 2015. 


\section{CHAPTER II: METHODOLOGY}

"2. The revolutionary knows that in the very depths of his being, not only in words but also in deeds, he has broken all the bonds which tie him to the social order and the civilized world with all its laws, moralities, and customs, and with all its generally accepted conventions. He is their implacable enemy, and if he continues to live with them it is only in order to destroy them more speedily." - Sergey Nechayev

Terrorism studies, and with the particular emphasis on counterterrorism, require a multifaceted and interdisciplinary approach, which is reflected in the methodology of this thesis. This chapter will highlight this thesis' use of four methodological approaches: the application of a theoretical frame (through the lens of policy harmonization and deterrence theory/reintegration shaming theory); examining a single case study; conducting a policy analysis of European and Italian counterterrorism measures; and the use of quantitative data to support this thesis' hypotheses.

\section{A. THEORETICAL FRAMEWORKS}

In many bureaucratic and administrative circles, one would be hard-pressed to find a civil servant that actively attempts to apply theories derived from political thought and international relations to the policies that they draft for their respective governments and/or organizations. More often than not, a division exists between academics and policymakers because of their preferred methodologies (quantitative versus qualitative, respectively), despite the desire for cooperation between the two fields. ${ }^{23}$ Policymakers and practitioners who conduct foreign policy

\footnotetext{
${ }^{23} \mathrm{http}: / /$ foreignpolicy.com/2012/01/03/the-beltway-vs-the-ivory-tower/; https://www.theguardian.com/higher-educationnetwork/2014/nov/11/academics-grab-policy-makers-attention; https://www.washingtonpost.com/news/monkeycage/wp/2013/09/25/what-do-policymakers-want-from-academics/; https:/www.theguardian.com/higher-educationnetwork/blog/2011/jun/07/academics-learn-influence-government-policy;
} 
often ignore academics who study international relations on account that they feel as though "abstract theories" have no place in practice. ${ }^{24}$ As a result, it may seem contradictory to apply theoretical approaches as the primary methodology to a thesis that heavily focuses on how to establish more effective policy; however, it is that desire for a convergence between practice and theory that drives this thesis to merge the European Beltway with the Ivory Tower. In the following subsections, this chapter explores policy harmonization and deterrence theory, and how they fit into the overall hypotheses and argument for this thesis.

\section{Policy Harmonization}

The conceptual understanding of policy harmonization at the European level is derived from the Rome Treaty (1957) of the European Community (EC), now known as the EU. Central harmonization was emphasized as a way for the member states to streamline their national laws and policies in order to establish and maintain a common European market. ${ }^{25}$ Simply put, harmonization in this context can be understood as a tool for deeper market integration because it requires standardized regulations across all member states; but as a result of the spill over, connected policy areas are also impacted. National political authorities are the drivers of policy harmonization. National policies are developed to reflect the regulations and standards created by the supranational authority (i.e. the EU in this case). Euroskeptics criticize policy harmonization for shifting national autonomies to a supranational entity, thus pushing the EU to operate more as a state than a regional organization.

\footnotetext{
${ }^{24} \mathrm{http}: / /$ www.columbia.edu/itc/sipa/S6800/courseworks/foreign_pol_walt.pdf

${ }^{25}$ Giandomenico Majone (2014) Policy Harmonization: Limits and Alternatives, Journal of Comparative Policy Analysis: Research and Practice, 16:1, 4-21, DOI: 10.1080/13876988.2013.873191
} 
Deterrence Theory and Reintegrative Shaming Theory: Crossing International Relations with Criminology

At its most rudimentary understanding, deterrence theory involves a defending party to communicate and to exert coercive capabilities (when necessary) against an adversarial party, thus forcing the adversary to consciously decide it is against their interest to threaten the defending party. The idea of deterrence theory implies that the adversarial party is forced to conduct a cost-benefits analysis of their actions, further insinuating that they are a rational actor. There are three criteria of deterrence that have been identified by scholars of international relations: (i) proportionality, in which the defending party limits its use of military force unless deterrence via threats fail; (ii) reciprocity, in which there is an explicit understanding of the linkage between the defending party's threats and the attacking state's concessions; and (iii) coercive credibility, in which the defending party convinces the adversary that non-cooperation has consequences. ${ }^{26}$

Deterrence theory itself is not a new concept and has been applicable for as long as states and empires have been engaged in combative affairs, but the theory became prominent during the Cold War as a result of the arms race between the United States and the Soviet Union. Deterrence theory has played a role in offensive neorealism to explain the security competition among great powers in the anarchic international system. John Mearscheimer, who is considered one of the "founding fathers" of neorealism, explains that states are not satisfied with the given amount of power and seek hegemony for security. Defensive neorealism (a field established by Kenneth Waltz, who is also considered a "founding father of neorealism") applied deterrence

\footnotetext{
${ }^{26}$ Bruce W. Jentleson and Christopher A. Whytock, "Who 'Won' Libya? The Force-Diplomacy Debate and Its Implications for Theory and Policy," International Security 30, no.3 (2006), https://doi.org/10.1162/isec.2005.30.3.47
} 
theory to nuclear proliferation as well, arguing that all states should stock their own nuclear arsenal to prevent other states from attacking them.

Due to neorealism's popularity during the Cold War, the literature on deterrence theory is expansive, particularly in regard to the theory's understanding of nuclear proliferation and the anarchic international system. However, deterrence theory does not need to be used explicitly to understand state behavior; it has been used in other disciplines to explain the behaviours of individuals, particularly at the intersection of criminology and psychology. Jeremy Ginges identified two major deterrent strategies that are used against individuals convicted on terrorism charges. ${ }^{27}$ The first strategy is the Denial Strategy, which was an earlier strategy developed under deterrence theory and it involves minimizing the benefits of the convicted individuals and increasing the adversarial party's costs through legal sanctions. This strategy's main tenants incorporate the refusal to negotiate with terrorist groups, increasing police powers, and in some case, actively retaliating against terrorist groups and their sponsors. Ginges uses Israel as a clear example of applying the Denial Strategy in their counterterrorism policies, which includes target hardening, retaliation against terrorists, and no concessions or negotiations with terrorist groups. The Denial Strategy integrates a limited understanding of the conventional 'utility theory' of crime deterrence, while focusing on the fear of legal punishment as a deterrent and ignoring extra-legal sanctions as a way to prevent individuals from engaging in terrorism.

The second strategy, reintegrative shaming, is a more modern understanding of effective strategies for deterrence. The reintegrative shaming strategy recognizes the cost of non-legal sanctions to individuals and groups in engaging in terrorist activities, and the need to reintegrate convicted terrorists back into society. As a result, the reintegrative shaming strategy addresses

\footnotetext{
${ }^{27}$ Jeremy Ginges, "Deterring the Terrorist: A Psychological Evaluation of Different Strategies for Deterring Terrorists," Terrorism and Political Violence 9 no.1, 1997.
} 
factors and issues that persuade individuals to engage in terrorist activities ${ }^{28}$, namely alienation and the process of reintegration itself. Punishment is still an important component to reintegrative shaming because it is required to uphold the moral code of society, but this strategy does recognize the importance of drawing the terrorist back into society. ${ }^{29}$ Based on John Braithwaite's theory of shaming ${ }^{30}$, which explains the effects of shaming on criminals, Ginges explores how reintegrative shaming employs a model of deterrence that reduces the utility of the terrorist acts by examining Italy's experience with reintegrating ${ }^{31}$ convicted terrorists in the late 1980s. ${ }^{32}$

In his research, Ginges notes that from a psychological perspective, the application of the reintegrative shaming theory seems to be the counterterrorism strategy with the most potential for success because it recognizes the complex purposes of the terrorist and acknowledges the terrorist as a rational actor. ${ }^{33}$ Ginges also uses Italy as a case study to exemplify the success this strategy has had in Italy's counterterrorism efforts in the 1980s. While he does provide a disclaimer that his research focused on political extremists, he does suggest that the reintegrative shaming would also be applicable in the efforts against religious extremism. Additionally, Ginges highlights an important message in his research, stating that "it is only possible to determine policy once we comprehend the nature of the [terrorist] phenomena that we are

\footnotetext{
${ }^{28}$ Chapter III will further examine the factors that drive individuals to take part in and support terrorist organizations.

${ }^{29}$ Ginges, 1997, 175.

${ }^{30}$ John Braithwaite's theory of shaming explains the effects of shaming on criminals by breaking down the theory into three components. First, for shaming to affect the criminal, they must recognize the legitimacy and morality of the institutions convicting them. Second, criminals with less interdependency on the "normal" population and greater interdependency on the criminal subpopulation are less likely to be influenced by shaming. Third, there must be a recognition of the different types of shaming used by different societies, namely reintegrative shaming (which reduces the utility of terrorist acts and is used as a deterrent for further participating in terrorist activities) and stigmatization (which creates criminal subcultures). Source: John Braithwaite, Crime, Shame, and Reintegration, Melbourne: Cambridge UP, 1989.

31 It should be highlighted that the Italian case in the 1980s differs from the present situation with jihadist extremism. Italian authorities took on the challenge of "reintegrating" Italian citizens back into society, whereas the contemporary issue with jihadist extremists in Europe is that they are not integrated into European society to begin with. As such, European states are faced with the challenge of "integration" more so than with "integration".

${ }^{32}$ Ginges, 1997, 173.

${ }^{33}$ Ibid., 1997, 181.
} 
dealing with. In this matter, understanding the motivations and perceptions of the terrorist is just as important as understanding the political, legal, and historical dimensions."34

Ginges' message reflects this thesis' theme, wherein the purpose of this research is to demonstrate how the EU's preventative counterterrorism measures are partially ineffective due to the fact that the components of deterrence theory's reintegrative shaming strategy are not taken into account, namely that the psychology of terrorism is ignored in policy. ${ }^{35}$ The counterterrorism measures enacted and enforced by the EU and its member states tend to focus on reactionary measures under the PROTECT and PURSUE pillars; measures under the PREVENT pillar are slowly becoming more prominent, but they still fail to address the individuality of various terrorist organizations and they fail to reintegrate convicted terrorists back into society. In the end, these counterterrorism measures continue to further feed into the feelings of alienation and perceived societal rejection that terrorists experience, thus not achieving any objectives of prevention.

\section{B. METHODOLOGY: SINGLE CASE STUDY}

The scope of this thesis is to consider a single case study as methodology by examining Italy and how it compares to the EU's overall approach to counterterrorism. This thesis has already identified a few specific reasons as to why Italy was isolated as an exceptional case to examine for the purposes of this research, namely: Italy's application of deterrence theory and the reintegrative shaming strategy in counterterrorism, preemptive and preventative measures, their

\footnotetext{
${ }^{34}$ Ginges, 1997, 182.

35 This thesis recognizes that there may be other factors not controlled for by this research that could also contribute to ineffective preventative counterterrorism measures; however, this thesis highlights the importance of understanding terrorism at the individual and organizational level and to combat the threat by tackling the psyche of the terrorist.
} 
extensive history and experience with extremism and organized crime, and their unique relationship with their Muslim community. Several broad control variables were also identified to explain the selection of Italy as the case study; these broader variables can be applied to future case studies examining an EU member state's counterterrorism efforts in comparison to the EU. The five variables selected are:

1. Geographic location: the selected country must be (a) a member of the EU; (b) a member of NATO; and (c) must be in Western Europe. Italy fulfill these requirements. Moreover, Italy is a founding state of the EU, which implies that they are more committed to the EU's idea of an "ever closer union".

2. Selected states are not members of deeply integrated intelligence-sharing networks: Unlike the UK, which is also a member state of the EU and a member of NATO, Italy is not a member of an intelligence-sharing network such as the Five Eyes Alliance (FVEY). ${ }^{36}$ This is a disadvantage because despite the existence of so-called European intelligence networks (including intelligence sharing capabilities between Europol and the European Union Military Staff [EUMS]), these sharing capabilities are not on par with the FVEY and many intelligence gaps exist, and thus, there are gaps for cooperation between states and institutions. This is also relevant to the remaining EU member states, all of whom would benefit from an integrated European intelligence agency that does not function as an arm of Europol.

3. Presence of terrorism: The presence of terrorism is a necessary requirement to be able to control for the effectiveness of existing strategies. The TE-SAT and the University of

\footnotetext{
${ }^{36} \mathrm{FVEY}$ is an alliance that dates back to World War II, which is comprised of the US, UK, Canada, Australia, and New Zealand. They operate under the "no-spy agreement", implying that Second Party members are forbidden from conducting surveillance and collecting intelligence within the boundaries of FVEY partners and on citizens from those states. These states share intelligence that may be of relevance to one another. Following the War on Terror, FVEY experienced an increased in surveillance powers.
} 
Maryland's Global Terrorism Database demonstrate that religiously inspired terrorism does not have a significant presence in Eastern Europe as it does in Western Europe.

4. External Involvement: The final variable that connects my case studies is the military and humanitarian involvement in the global "fight against terrorism". By considering the two most prominent missions since 9/11, one against Al Qaeda and the other against Daesh, it is evident that Italy plays a humanitarian role in the Middle East. However, Italy has more of an invested interest and concern in Daesh's growth in Libya, due to their proximity to Italy and the number of migrants that have travelled from Libya into Italy. ${ }^{37}$

\section{METHODOLOGY: POLICY ANALYSIS}

Three components for this thesis's policy analysis will be outlined in this section: the dual use of the qualitative analysis software NVivo, the process for coding, and the use of the SMART model.

Most comparative studies will apply a qualitative approach by using some form of a computer-assisted qualitative data analysis (CAQDA) tool to analyze the various strategies, policies, and laws, by coding them for different key words and compiling a dataset that can demonstrate the similarities and differences. This thesis utilizes NVivo specifically, a CAQDA tool that originated from the enhancement of the first qualitative data analysis software, "Nonnumerical, Unstructured, Data: Indexing, Searching and Theorizing," or NUD*IST as it was more commonly known in $1981 .^{38}$ NUD*IST helped researchers by indexing components of textual documents and searching for words and phrases in the data. The analysis (linking of

\footnotetext{
37 --. "Isis in Libya: Gentiloni and al-Sarraj express deep concern." News on Italy at the UN. Published on 5 January 2016. http://www.onuitalia.com/eng/2016/01/05/isis/

${ }_{38}$ Jones, M., and K. Diment, "The CAQDA Paradox: A Divergence between Research Method and Analytical Tool," Paper presented at the 2nd International Workshop on Computer-Aided Qualitative Research, 4-5.
} 
themes, contexts and categories) requires a manual handling of data at various points throughout the analysis by the researcher because there are no functions for automation. NVivo's most recent product was released in 2012 and it maintains this manual component. As a result, this requires the researcher to read through documents individually, and to code the data and develop their own themes and categories.

NVivo's function for analyzing empirical documents (e.g. interview transcripts, documents, and survey responses) will be necessary due to the large number of policies and strategies available by the EU and the chosen case studies. Additionally, this will allow the research to move forward with an organized method of examining the available documents and compiling a qualitative data set that can be examined to determine how the policy affects different counterterrorism strategies and operations. It is important to note that all documents that are being analyzed are unclassified and available through open-source research.

The prospective policy and content analysis of qualitative data will depend on how this research frames the counterterrorism policies of the EU and its member states. The following categories were identified while coding the data in NVivo, and they are based on criteria of effectiveness. The criteria were also developed based on the existing literature on the subject and the researcher's own synthesis and analysis.

1. Presence of a clear objective: Does the policy/strategy/legal instrument/institution outline an objective for its counterterrorism measures? For the purposes of my research, I will examine the clarity and quality of policy objectives based on the SMART model ${ }^{39}$, which is arguably the most standard and well-known model for goal-setting. This is consistent with Martins and Ferreira-Pereira's (2012) findings that effectiveness is

\footnotetext{
39 SMART objectives imply that an objective is specific, measurable, attainable/achievable, realistic/relevant, and time-bound. Source: Kevin F. Cross and Richard L. Lynch, "The 'SMART' Way to Define and Sustain Success," in Global Business and Organizational Excellence 8:1 (1988).
} 
correlated with the presence of clear counterterrorism objectives. According to them, in the case of the EU, there are no clear objectives stated in their existing documents, indicating ineffectiveness.

a. Code whether there is an objective: "Yes", "No", and "Other" with provided explanation where necessary.

b. Code for how many of the five criteria of the SMART model are applied (numerical scale 1-5).

2. Application of the 2002 EU definition of "terrorism": Does the document in question use the definition provided in the Council Framework Decision of June 2002 (See article 1 of Annex C)? Or does it utilize a definition that is inconsistent? The consistent use of the same definition at the EU level and the member state level demonstrates harmonization of policies and indicates effectiveness.

a. Code either "Yes" or "No" for application of the EU's definition.

b. Determine discrepancies if coded "No".

3. "The Politics of Fear": How many official counterterrorism policies and strategies were present in the member state in question and the EU prior to a major terrorist attack in the West? How many counterterrorism policies and strategies were developed within (a) a month, and (b) a year following a major attack? This will require an analysis of the documents to determine what changes have been made in policy and whether the changes were only rhetorical (indicating ineffectiveness) or operational (indicating effectiveness).

a. Code with a numerical value indicating number of policies and documents prior to an attack, a month after an attack, and a year after an attack. 
4. Relevance to the EU Counterterrorism Strategy: Based on the four pillars of the EU's Counterterrorism Strategy of 2005 (PREVENT, PROTECT, PURSUE, and RESPOND), under which pillar can the measure be categorized? Measures were coded to fall under at least one of the four pillars; some measures fell under two or three pillars (depending on how robust and far reaching the measure was). Categorization was based on searching for key words that specifically pertained to the different pillars, as the strategy outlines what types of measures would fall under each pillar.

5. Specific to EU Measures $\rightarrow$ Theme: EU Measures were coded to fall under one of the identified categories:

a. "Third party cooperation" (with subcategories falling under "customs", "financial", and "general");

b. "Border security";

c. "Data sharing";

d. "Financial";

e. "General" (with subcategories falling under "policing" and "exchange of information");

f. "Justice";

g. "Law enforcement";

h. "Penalties"; and,

i. "Prevention".

Coding measures under one of the aforementioned categories allowed for the research to identify where the EU was focusing its policy development for counterterrorism, and whether they were only acting in areas they held legislative capabilities. 
6. Case study specific (Italy) $\rightarrow$ Is deterrence theory applicable to the selected measure: Code "Yes" or "No", provide explanation if a measure could not clearly fall under "Yes" or "No".

7. Case study specific (Italy) $\rightarrow$ Was the measure a byproduct of harmonization: Code "Yes" or "No", provide explanation if a measure could not clearly fall under "Yes" or "No".

The documents of the separate measures, which included 28 Italian measures and 139 EU measures entered into force between 2001 and 2016, were coded in NVivo and organized within a spreadsheet in Microsoft Excel in order to filter results and produce graphs to visualize the data.

The policy analysis evaluated 139 EU measures containing the word "terrorism" in their titles, that were implemented by the EU between 2001 and 2016. Due to the sheer number of the types of EU legislation and those that impact counterterrorism measures indirectly, this analysis focused only on EU legal acts that are considered hard law, or binding law, as they would have a direct effect on the legislation of the member states (regulations, directives, and decisions). This thesis acknowledges that there is a large number of measures not accounted for that fall under "soft" law, such as action plans, recommendations, and sharing of best practices, but it still captures the general idea that the EU has been very active in counterterrorism.

The policy analysis conducted for the Italy case study examined 28 Italian counterterrorism measures that contained the word 'terrorismo' in the title itself that could be populated in Italy's online legislative database, "normattiva.it". As a result, this only provides a snapshot of Italian counterterrorism measures because numerous pieces of legislation (that were either broad or directly related to another policy area) contained some provisions regarding counterterrorism 
activities. There are two reasons for only analyzing legislation with the word 'terrorism' in the title. First, given the limited time and resources, this allowed the researcher to focus specifically on a selective set of Italian-language measures, otherwise, there would be a couple hundred pieces of legislation requiring analysis. This would then also require invoking more qualitative metrics to examine trends in the legislation. Second, by selecting legislation that was solely dedicated to counterterrorism, it ensured that all of the examined measures are purely dedicated to the objective of countering terrorist groups and activities. To ensure that important policies were not omitted or missed, legislation containing the words "radicalismo", "radicale", and "estremista" were also queried in Italy's legislative database; no results were populated containing those aforementioned words in the title of Italian legislation.

This research applied the SMART model to determine the effectiveness of the objectives of counterterrorism measures, with the intent of developing a framework for future application of counterterrorism measures. While the SMART model was applied, a concise framework was not developed; however, the attempted use of the SMART model led to a contribution to the literature because no previous studies evaluated the objectives of counterterrorism measures by taking a systematic approach such as the SMART model.

\section{APPLICATION OF QUANTITATIVE DATA}

Quantitative research, as seen above, will also be used on a smaller scale by analyzing the statistics on arrests, attacks, and foreign fighters. To conduct my research, I will be deriving most of my information from official documents by the government of Italy, and from the official documents of the EU. Additionally, this thesis will rely on data provided by the University of Maryland's Global Terrorism Database, which maintains records on 170000 cases of terrorist 
attacks around the world since 1970. As thorough as the database aims to be, there are limitations that are explained on their website. ${ }^{40}$ As mentioned before, these will include official strategies, policies, and laws that pertain to anti-terrorism measures, national security, and international security. This research used the data visualization software, Tableau, to populate the data extracted from the Global Terrorism Database and to generate graphics for such a large dataset.

Furthermore, my research will also need to conceptualize the terminology that will be used extensively in the research - particularly the term "terrorism", which has been contested across the literature. The conceptualization of "radicalization", "extremism", and "counterterrorism" will also have to be framed. Despite my research focusing on the policies and strategies, I will also have to briefly explore the theories on radicalization and terrorism and how counterterrorism has addressed these issues, which may provide insight on strategy and policy for preventing terrorism.

\section{CHAPTER III: LITERATURE REVIEW}

"3. The revolutionary despises all doctrines and refuses to accept the mundane sciences, leaving them for future generations. He knows only one science: the science of destruction. For this reason, but only for this reason, he will study mechanics, physics, chemistry, and perhaps medicine. But all day and all night he studies the vital science of human beings, their characteristics and circumstances, and all the phenomena of the present social order. The object is perpetually the same: the surest and quickest way of destroying the whole filthy order." - Sergey Nechayev

\footnotetext{
${ }^{40}$ The collection of entries within the Global Terrorism Database was done in real time for cases between 1970 and 1997 , was retrospective between 1998 and 2007, and is again in real time after 2007. This distinction is significant because some media sources have since become unavailable, undoubtedly impeding efforts to collect a complete census of terrorist attacks between 1998 and 2007. Methodological improvements have been made since 2012 resulting in differences in levels of attacks and casualties before and after January 1, 1998, before and after April 1, 2008, and before and after January 1, 2012. Furthermore, cases from 1993 were lost prior to receiving the data. Efforts thus far have been unsuccessful in fully recovering the 1993 data. Instead of providing a partial listing of cases for 1993, the website refers users to a table with total number of attacks in 1993 for each country, which can be found in the GTD's codebook. Source: "Using GTD." Global Terrorism Database. 
Prior to delving into this paper's research on the efficacy of the EU Member States' counter-terrorism strategies and on the convergence of internal and external security measures, a brief review examining the existing literature on a few interconnected branches of terrorism studies will be conducted. As the overall topic of this thesis explores the efficacy of counterterrorism strategies and policies, this will be one of the primary topics highlighted in this literature review. However, in addition, it is also necessary to look at two foundational topics that build on the aforementioned: how/why terrorist groups start and how/why terrorist groups end. By determining what factors influence the beginnings and endings of a terrorist group, it allows for researchers and policymakers to make more informed decisions regarding the design and implementation of various policies and strategies. It is necessary to note that these questions on the emergence and cessation of terrorist groups could be expanded into their own respectful dissertations due to the weight these questions carry, therefore this literature review aims to provide the foundational conclusions that have been developed in the field of terrorism studies.

Following the analysis on the literature regarding the emergence and cessation of terrorist groups, this literature review will answer the overarching question that provides a baseline for this entire dissertation: are counter-terrorism strategies and policies effective? This literature review finds that the consensus amongst academics can be divided into two camps; counterterrorism measures are either (a) conditionally effective; or (b) their effectiveness is uncertain due to inconsistent evaluations of counter-terrorism measures. No examined researcher has concluded that counter-terrorism measures as a sum are ineffective, seemingly because they view the counter-terrorism theatre with low expectations, believing that any approach is better than no approach. Even though these conclusions could be drawn from the available literature, it should 
be highlighted that the literature on counter-terrorism effectiveness is extremely limited and consists of many literature reviews that repeat previous findings. The majority of the examined authors fall into the second camp of conclusions (it is uncertain whether counter-terrorism measures are effective), thus failing to contribute to the limited number of decisive terrorism research findings and literature. It should also be noted that although this dissertation's focus is on religious fundamentalism in the form of Islamic extremists/jihadists, the research conducted for this literature review is also conducive to other forms of terrorism (left/right wing terrorism, ethno-nationalists, anarchists, etc.).

Overall, this literature review provides an examination on how research pertaining to the creation/cessation of terrorist groups has contributed to policy developments for counterterrorism purposes. A sizeable portion of literature was examined that is not solely related to counterterrorism policies and policy analyses, rather they broach on more sociological aspects. This is extremely beneficial for establishing effective counterterrorism policies, because as the acclaimed researcher Louise Richardson ${ }^{41}$ points out, the best way to combat and contain terrorism is to understand its appeal and understand the individuals/groups that act as a government's adversary - a basic tenant that Sun Tzu would certainly endorse. ${ }^{42}$

\section{A. THE EMERGENCE OF TERRORIST GROUPS}

Examining the emergence of terrorist groups necessitates two similar questions: why are terrorist groups created and how are terrorist groups created? By framing the first question as "why" terrorist groups are created, it allows for researchers to pinpoint the fundamental principles resulting in the formation of terrorist groups (their motivation and agenda), thus

\footnotetext{
${ }^{41}$ Louise Richardson, What do terrorists want? Cambridge: Harvard Press 2006.

${ }^{42}$ Sun Tzu The Art of War.
} 
providing a baseline in which to focus their policies and strategies. This is particularly important because strategies, and the policies that are derived from them, require a macro vision as a starting point to move toward the creation of specific objectives. The second question's emphasis on the "how" aspect of terrorist group emergence steers the focus to the organizational and bureaucratic characteristics of the development of terrorist groups, in addition to the recruitment strategies of terrorist groups. There are three categories that can be derived from the available literature on the topic of the emergence of terrorist groups, and how to combat new groups from surfacing: motivations, objectives, and organizational/bureaucratic characteristics.

\section{Motivations}

Though "motivations" and "objectives" can be seen as connected classifications, for the purpose of this dissertation's analysis, they are identified as two separate categories because "motivations" can be understood as catalytic experiences and/or thoughts that lead an individual to establish a terrorist group, join one themselves, or to simply support the rhetoric and actions of a terrorist group. Whereas "objectives" imply the strategic goals of the terrorist group upon its creation. In his research on motivations for supporting terrorism, Dirk T.G. Rúbbelke explains that "motivations do not include the aim of terrorism", thus supporting the division between the two categories. ${ }^{43}$ Rúbbelke concurs that motivations focus on the individual agent's sphere rather than the organization structure of a terrorist group, therefore also supporting the division between the "motivations" and "organizational/bureaucratic characteristics" categories. ${ }^{44}$

Rúbbelke's research on terrorist motivations are centered on monetary incentives. Through his research on the individuals' motivations for supporting terrorism, the outcomes

\footnotetext{
${ }^{43}$ Dirk T. G. Rúbbelke, "Differing motivations for terrorism,” Defence and Peace Economics, 16:1, 2006: 19-27, DOI: 10.1080/1024269052000323524: 19

${ }^{4}$ Ibid.
} 
allowed for the development of three main policy options to combat terrorism based on the premise that terrorists/terrorist sympathizers are rational actors. First, terrorism organizations provide monetary incentives to individuals as motives for them to join their organizations and/or to carry out attacks; therefore, policies that aim to disrupt the flow of income to terrorist organizations (or as Rúbbelke states in a more general matter, any social group susceptible to terrorism) might reduce the level of terrorism. However, these policies could be ineffective in the long-term because they may increase the terrorist's willingness to commit suicide attacks because the individual weighs the benefits of committing a suicide attack and obtaining benefits in the "after-life" (as promised by martyrdom) versus participating in the organization and obtaining financial benefits. Therefore, when financing is cut off, the individual is more likely to see maximal benefits in committing a suicide attack. ${ }^{45}$ Rúbbelke believes that his remaining two policy options would yield more effective counterterrorism measures: a rewards-based system and an "exit" option. The rewards-based system would have the governments provide options for additional income to "reward" peaceful actions from terrorist groups, thus creating a different channel of motivation based on monetary incentives. The "exit" option is founded on the idea that terrorist organizations place social pressure on individuals to motivate them into carrying out terrorist attacks, therefore governments should provide offers for terrorism sympathizers to exit their social group.

Rúbbelke's "exit" option can connect well with Arjun Chowdhury and Scott Fitzsimmon's research, in which they find that often, terrorist recruits are either loyal or competent; ideally, a recruit would have both characteristics. ${ }^{46}$ If we take Chowdhury and Fitzsimmon's findings into consideration with Rúbbelke's "exit" option, it is evident that there is

\footnotetext{
${ }^{45}$ Ibid., 23-24.

${ }^{46}$ Arjun Chowdhury and Scott Fitzsimmon, 2013, 449.
} 
some consistency in the findings that could suggest that governments can orient this "exit" strategy to primarily target the competent recruits. Recruits that are only characterized as competent tend to join and/or support terrorist organizations based on their self-conducted costbenefit analysis (e.g. benefits may include a reliable source of income, safety and security for themselves and their families, or they believe that defending the cause is worth the risk of joining the organization). An "exit" option would provide new incentives to motivate individuals to leave the terrorist group without fear of repercussion (such as serving time in prison).

At first glance, the literature seems conflicted when discussing whether monetary incentives truly serve as a means of motivation causing an individual to join/support a terrorist organization. Researchers such as Rúbbelke, Chowdhury, and Fitzsimmon do consider how income may attract some people to a terrorist organization, but this is looked at as one factor amongst several others. Questions have arisen regarding the connection between poverty and terrorism, but there seems to be a consensus throughout a widespread of the literature suggesting that there is no direct causal connection between the two. ${ }^{47}$ Armando Bocconi finds that it is not poverty and financial incentives that motivate individuals to join/support/create terrorist organizations, but rather the lack of prospect for development within their country and the likelihood that the future situation will deteriorate even more. ${ }^{48}$ The lack of future prospects creates an environment that feeds feelings of anger, humiliation, a desire for revenge (against capitalist, Western democracies), and a desire to attain glory and create a worthy future - all of which Richardson attributes to as motives for terrorism. ${ }^{49}$ In his research on jihadist terrorism in

\footnotetext{
${ }^{47}$ Armando Bocconi 2004; Alan B. Krueger and Jitka Maleckova 2003

http://www.sas.rochester.edu/psc/clarke/214/Krueger03.pdf; Russell and Miller 1983; Luciano Capone 2015

http://www.sanatzione.eu/wp-content/archivio media/uploads/2015/12/URN-Sardinnya-Lopinione-Su-terrorismo-epovert $\%$ C3\%A0.pdf; Jean Baudrillard 2002

https://monoskop.org/images/e/e2/Baudrillard Jean Lo spirito del terrorismo 2002.pdf;

${ }^{48}$ Armando Bocconi, "Ipotesi sulle cause e gli obiettivi del terrorismo cosiddetto islamico: le possibili soluzioni," 2004.

${ }^{49}$ Richardson, 2006, 15.
} 
Italy and Europe, Lorenzo Vidino also concluded that although financial incentives should be taken into account, there is little evidence supporting the notion that an individual's socioeconomic position drives them toward radicalization. ${ }^{50}$

While underdevelopment serves as a purpose for individuals to join terrorist organizations and preserve and pursue their subjectively justifiable self-interests, terrorism researchers have identified four categories that describe the amalgamated motivations leading to the creation of terrorist organizations: national separatism, revolution, reactionary (single-cause issues), and religion. ${ }^{51}$ These categories are not limited to academia; governmental and intergovernmental agencies also use them to an extent when analyzing how to combat their adversaries. Europol's annual TE-SAT divides the motives off terrorists between similar categories: religiously inspired terrorism, ethno-nationalist and separatist terrorism, left-wing and anarchist terrorism, right-wing terrorism, and single-issue terrorism. ${ }^{52}$ The political segments of terrorism (left-wing/anarchist and right-wing) could both be seen as "revolutionary" motivations of terrorism, albeit with their own ideas of what a revolution would resemble. David Rapoport, a highly well-regarded terrorism researcher who was one of the first in the field, applies similar categories of motivation, but he defines different time periods and the correspondence to terrorism since the $19^{\text {th }}$ century. His categories describe the four waves of modern terrorism and are defined by their primary motivations: anarchy, self-determinate ("anti-colonial terrorism"), [left-wing] radicalism ("new left terrorism"), and religious. ${ }^{53}$ With these key motives in mind and how terrorist organizations are divided based on these motivations, it is possible to further examine these groups and their objectives.

\footnotetext{
${ }^{50}$ Lorenzo Vidin,.."Il jihadismo autoctono in Italia: nascita, sviluppo e dinamiche di radicalizzazione" ["Domestic Jihadism in Italy: the Birth, Development and Dynamics of Radicalization,’] ISPI, Milano, 2014.

http://www.ispionline.it/it/EBook/Il jihadismo autoctono in Italia.pdf

${ }^{51}$ Gregory D. Miller, "Confront terrorism: group motivation and successful state policies," 2007.

${ }^{52}$ EU TE-SAT https://www.europol.europa.eu/activities-services/main-reports/eu-terrorism-situation-and-trend-report

${ }^{53}$ David C. Rapoport, “The Four Waves of Modern Terrorism,” 2004.
} 


\section{Objectives}

In his examination of successful state policies targeting terrorist groups, Gregory Miller finds that what is often missing from policies is the discussions as to what characteristics distinguish terrorist groups and the influence these characteristics have on counterterrorism effectiveness. ${ }^{54}$ Where motivations vary between individuals, objectives vary between groups; Miller's conclusion that counterterrorism policies and strategies fail to acknowledge distinguishing characteristics amongst terrorist groups is strongly applicable in the case of objectives. Each terrorist organization has established objectives that drive their agendas forward, and are outlined in their manifesto. Some broad and over-reaching objectives may overlap across groups, but each group and its head organization tend to have specific objectives that they wish to achieve. Objectives are communicated to the governments they attempt to terrorize (e.g. one of Al Qaeda's objectives was to remove western influences in the Middle East and their demand was that the United States [US] and Israel cease relations) ${ }^{55}$, yet these governments tend to discount the list of (often) political objectives and they are reduced to irrational actors who have no goals in mind beyond terrorizing the West.

There is consensus in the literature supporting the notion that terrorists are rational actors, which Shapiro recognizes is a difficult idea to come to terms with because it involves paving a rational pathway to an individual's decision to injure and/or kill in the name of their cause. ${ }^{56}$

\footnotetext{
${ }^{54}$ Gregory D. Miller, "Confronting Terrorism: Group Motivation and Successful State Policies,” 2007.

${ }^{55}$ U.S. Department of Defense, 21 st Century Complete Guide to Terrorism and the Government Response to September 11th: including Al Qaeda (al-Qaida) Training Manual. New York, N.Y.: Progressive Management 2002 ; Daniel L. Byman, "Comparing Al Qaeda and ISIS: Different goals, different targets," Brookings, 2015, https://www.brookings.edu/testimonies/comparing-al-qaeda-and-isis-different-goals-different-targets/ ; Mary Habeck, "What does Al Qaeda want?” Foreign Policy, 2012, http://foreignpolicy.com/2012/03/06/what-does-al-qaeda-want/

${ }^{56}$ Shapiro, 2015; Eric van Um, "Discussing Concepts of Terrorist Rationality: Implications for Counterterrorism Policy," Defence and Peace Economics 22 no.2 (2011) ; Emily Pronin, Kathleen Kennedy \& Sarah Butsch, "Bombing Versus Negotiating: How Preferences for Combating Terrorism Are Affected by Perceived Terrorist Rationality," Basic and Applied
} 
Richardson regards terrorists as rational actors that seek three immediate objectives: exact revenge, acquire glory, and force their adversary into a reaction (a desired reaction would be a change in policy, e.g. removing Western forces from the Middle East). ${ }^{57}$ Whereas Miller focuses on the specific objectives in comparison to Richardson's broad objectives, both have an important role in creating effective counterterrorism tactics. Broad objectives allow for state governments to establish overarching strategies that are oriented to tackle a terrorist organization's desire for revenge, glory, and reaction; but specific objectives allow a government to focus on creating policies that target specific adversaries. In their research paper on the objectives of terrorism (applying Al Qaeda as their case study), Gregory L. Keeney and Detlof von Winterfeldt divide Al Qaeda's objectives into three categories to determine what drives them and what governments should focus on:

1. Means objectives: guidance for short term actions (e.g. train insurgents, attack US personnel in Iraq, put aside Muslim sectarian differences);

2. Fundamental objectives: guidance for specific major decisions over medium- to longterm (e.g. win hearts and minds of Muslim masses, inflict economic cost on US); and

3. Strategic objectives: guidance for all decisions (e.g. establish Islamic authority, expel Western powers from the Middle East). ${ }^{58}$

These objectives are not mutually exclusive and it is necessary to note that each one feeds into its successor. Keeney and von Winterfeldt found that states do tend to focus on Al Qaeda's objectives of killing numerous Westerners and destroying the US economy, but they note that objectives are much more complex, and sometimes terrorist leaders must make tradeoffs between

Social Psychology 28 no.4 (2010) ; Simon Perry \& Badi Hasisi, "Rational Choice Rewards and the Jihadist Suicide Bomber," Terrorism and Political Violence 27 no.1 (2015).

${ }^{57}$ Richardson, 2006, pp. xxii.

${ }^{58}$ Gregory L. Keeney and Detlof von Winterfeldt, "Identifying and Structuring the Objectives of Terrorism," National Center for Risk and Economic Analysis of Terrorism Events, 2009. 
their objectives and courses of action, which can throw off the governments tackling terrorist organizations. Similarly to Miller, Keeney and Winterfeldt conclude that it is necessary for analysts (and policy makers) to understand the motivations and objectives of terrorist organizations because it allows for better, and more effective, counterterrorism recommendations.

\section{Organizational and Bureaucratic Characteristics}

In Jacob Shapiro's book, “The Terrorist's Dilemma”, he focuses on the organizational characteristics of terrorist organizations and declares that one problem in counterterrorism efforts is that governments do not treat terrorist organizations as just another rational-acting bureaucratic organization. ${ }^{59}$ Rather, government officials and policy makers have embellished the nature of terrorist organizations, reduced them to irrational actors, and they fail to acknowledge that individuals act on behalf of the collective.

Max Abrahms, Nicolas Beauchamp, and Joseph Mroszczy have identified that scholars have recently begun to turn to an organizational explanation that emphasizes how terrorist groups are "internally heterogeneous social units rather than unitary actors". ${ }^{60}$ To combat a group, it is necessary to understand its structural components, which can be understood by examining the typology of organizations and the basic elements of their characteristics. Although their research is dated at this point, Shaul Mishal and Maoz Rosenthal highlight four organizational characteristics that they apply to their comparative study on terrorist organizations: communicational structure within the organization; level of specialization and

\footnotetext{
59 "The terrorist's dilemma" by Jacob N. Shapiro 2015

${ }^{60}$ Max Abrahms, Nicholas Beauchamp \& Joseph Mroszczy, "What Terrorist Leaders Want: A Content Analysis of Terrorist Propaganda Videos," 2016, 2.
} 
division of labour; chain of command and control; and implementation of planned actions. ${ }^{61}$ These characteristics are timelessly transposable and are applied to various degrees by other researchers studying terrorist organizations. Thus, many researchers in recent years have examined two organizational models adopted by terrorist groups: hierarchal and network structures. $^{62}$

Hierarchal structures have a well-defined vertical chain of command, control, and responsibility $^{63}$, which respond well to counterterrorism methods that involve capturing/killing the leaders of these organizations. ${ }^{64}$ Lee Hamilton finds that hierarchal organization models are not used as frequently by contemporary groups in the Twenty-First century, and were primarily adopted by radical leftist organizations and ethno-nationalist groups. ${ }^{65}$ Hierarchal structures rely on individuals who are charismatic and are foundational to a group's direction. In comparison, network structures provide more flexibility for an organization as it enables individuals to have loose affiliations with the organization and there is an emphasis placed on taking initiative. Network structures allow for the organization's leaders to dictate an overall strategic vision that its members and followers can carry out in whatever manner is most accessible to them. ${ }^{66}$ Although network structures provide an advantage for terrorist organizations by allowing them to have a further outreach (particularly with the use of technology and social media), network structures are also at a disadvantage as they relied on independent cells, which may not always

\footnotetext{
${ }^{61}$ Shaul Mishal and Maoz Rosenthal, "Al Qaeda as a Dune Organization: Toward a typology of Islamic terrorist organizations," 2004, 14. https://www.files.ethz.ch/isn/46602/mc20.pdf

${ }^{62}$ Shapiro, 2015 ; Abrahms et al. 2016 ; Shaul Mishal and Maoz Rosenthal, 2004 ; Renate Mayntz, "Hierarchy or Network? on the Organizational Forms of Terrorism," Berliner Journal Fur Soziologie 14 no.2, 2004 ; Lindsay Heger, Danielle Jung, and Wendy H. Wong, "Organizing for Resistance: How Group Structure Impacts the Character of Violence," Terrorism and Political Violence 24 no.5, 2012 ; Walter Enders and Paan Jindapon, "Network Externalities and the Structure of Terror Networks," The Journal of Conflict Resolution 54 no.2, 2010.

${ }^{63}$. Lee Hamilton, "Chapter 3: Terrorist Organization Models", A Military Guide to Terrorism in the Twenty-First Century, 2007, pp.6. http://www.au.af.mil/au/awc/awcgate/army/guidterr/ch03.pdf

${ }^{64}$ Shapiro, 2015; Abrahms et al., 2016; Mishal and Rosenthal, 2004.

${ }^{65}$ Hamilton, 2007, 6.

${ }^{66}$ Ibid., 7.
} 
meet the organization's objectives. Network structures may also seem clear-cut in definition, but Shapiro found in his earlier research that networking is a matter of degree, and an organization cannot adopt both hierarchal and network characteristics. ${ }^{67}$

Al Qaeda demonstrated a shift from this model, wherein they adopted a combination of hierarchal and network organization models following the 9/11 attacks. Mishal and Rosenthal describe this third model as a "dune" organization - although characteristics from the models can be identified, the dune organization is unique because its defining feature is the "randomness" of the organizations' locations and operations. Dune organizations adapt to its surroundings and the climate of geopolitics and international relations at the time. They also challenge two issues found with hierarchal and network approaches: first, the organizations do not require territorial affiliation, allowing for the organizations' headquarters to relocate as required, and secondly, dune organizations do not require permanent institutional headquarters. ${ }^{68}$ Mishal and Rosenthal are not the only ones to examine this evolution of organizational structures for terrorist groups; several researchers have classified these hybrid models under various names with slightly different characteristics. John Aquilla and David Ronfeldt discuss the "all-chain" network, which incorporates the fluidity of information transfer between individuals that is found in traditional network structures, and while there is no leader in this model, there is still a well-defined internal structure. $^{69}$

\section{B. "HOW TERRORIST GROUPS END"}

\footnotetext{
${ }^{67}$ Jacob N. Shapiro, “Organizing Terror: Hierarchy and Networks in Covert Organizations,” 2005, 3-4. http://www.teachingterror.net/resources/Shapiro\%20organizing\%20Terror.pdf

${ }^{68}$ Mishal and Rosenthal, 2004, 8.

${ }^{69}$ John Aquilla and David Ronfeldt. "Networks and Netwars The Future of Terror, Crime, and Militancy .” 2001. 7-8. RAND. http://www.rand.org/pubs/monograph reports/MR1382.html
} 
This subsection's question is posed in the overtly titled and frequently cited paper by RAND Corporation. The researchers, Seth G. Jones and Martin C. Libicki, analyzed 648 groups that existed between 1958 and 2006 to determine how they ended. The purpose of their research paper was to provide United States counterterrorism officials with a guideline of approaches that have been proven to be successful with unravelling terrorist organizations, and to assess implications for countering Al Qaeda. The final product proved to be a critical document to future counterterrorism studies, as it is cited in nearly every paper and book that I have analyzed for this literature review. Jones and Libicki find that since 1968, most terrorist groups have ceased to exist because they either joined the political process (43 per cent of groups), or local police and intelligence agencies arrested or neutralized key members of the organization (40 per cent of cases). In very few cases (10 per cent), terrorist groups ended because they achieved their objectives. Jones and Libicki concluded that military force has rarely achieved success in vindicating terrorist organizations (7 per cent of cases), demonstrating that the internal security structures of a state (institutions that would have mandates to oversee domestic threats and crimes against the state, including but not limited to law enforcement agencies at various levels, ministries of interior, domestic intelligence agencies, and the jurisprudential system) have been proven to be more effective for counterterrorism than external security structures (institutions that have mandates to act in the interest of the state outside of the state's borders, including the various apparatus of the military, foreign intelligence agencies specializing in military intelligence, imagery intelligence, and signals intelligence). However, military force has been proven to be the most successful tactic for combating insurgent groups, which are "the most capable and lethal"'. 
Jones and Libicki's study found that the political process is particularly successful when the terrorist organizations have narrow policy objectives in mind, allowing for negotiations to take place between the organization and the government in question in a non-violent manner. For terrorist organizations that refuse to make a transition to nonviolence and cooperate with the government, law enforcement is the most effective strategy. The study also yielded results illustrating that religious terrorist groups took longer to eradicate; while 62 per cent of all terrorist groups ended between 1968 and 2006, only 32 per cent of religious terrorist groups ended in the same time frame, and they rarely achieved their objectives. Additionally, groups were more likely to survive if they had more than 10000 members and if they engaged in insurgency.

Their findings present important conclusions for determining the effectiveness of EU counterterrorism and identifying where resources need to be allocated to accomplish the desired outcomes. Based on Jones and Libicki's results, the EU would need to invest more into policing and intelligence to combat jihadist terrorism effectively. However, their study is flawed because they do not address preventative measures of combating terrorist organizations. How effective are policies that deter recruitment to groups, thus suppressing membership numbers particularly as members are neutralized? While I understand that their study predates the explosion of the ubiquitous use of social media, the EU and its member states are placing an emphasis on preventative measures that include "de-radicalization centres"70 and circulating alternative narratives, therefore it would be useful to take such initiatives into account.

\footnotetext{
${ }^{70}$ In September 2016, France introduced 12 new centres for de-radicalization, officially titled Centers for Prevention, Integration and Citizenship. These centres are aimed at young people who are vulnerable to radicalization and susceptible to joining terrorist organizations or taking part in acts of terrorism. (https://www.washingtonpost.com/world/europe/france-to-open-first-of-12deradicalization-centers-for-at-risk-youths/2016/09/14/d596d7fe-7a78-11e6-8064clddc8a724bb story.html?tid=a inl\&utm term=.e2de4e3374bd)
} 
Despite the effectiveness of policing for counter-terrorism efforts, and the limited success of military force, Jones and Libicki do find that military force has been critical to eradicating terrorist organizations that manifest themselves as insurgent groups. Notable scholar Bard O’Neill, a counter-insurgency (COIN) specialist, defines insurgencies as "a struggle between a non-ruling group and the ruling authorities in which the non-ruling group consciously uses political resources (e.g., organizational expertise, propaganda, and demonstrations) and violence to destroy, reformulate, or sustain the basis of one or more aspects of politics". ${ }^{71}$ When applied to Europe's largest jihadist threat at this time, Daesh, the definition accurately describes the group as an insurgency. This diminishes the emphasis placed on policing and intelligence in effective counter-terrorism policies, because it is evident that the EU requires military force to combat Daesh. However, complications arise because, as this literature review states earlier, counter-terrorism measures must be curated to target specific groups and their various objectives; moreover, not all groups are considered insurgencies either. Therefore, the use of military force is not necessarily an effective strategy to apply uniformly in counter-terrorism, unlike policing or political settlements.

\section{EVALUATION OF THE EFFECTIVENESS OF COUNTERTERRORISM POLICIES AND STRATEGIES}

Since the "explosion of studies" conducted following the September $11 \operatorname{attacks}^{72}$, the literature on terrorism and counter-terrorism studies has become oversaturated with nonconclusive studies that tend to claim, at varying degrees, that there is an abundance of uncertainty when it comes to determining the effectiveness of counter-terrorism strategies and

\footnotetext{
${ }^{71}$ Bard e. O’Neill, Insurgency and Terrorism: Inside Modern Revolutionary Warfare (washington, DC: Brassey’s inc, 1990$), 13$.

${ }^{72}$ Kennedy, Lum, and Sherley 2006
} 
policies because of the lack of consensus ${ }^{73}$; or that these measures are effective, but they are tied to conditional factors ${ }^{74}$. Based on a thorough examination of the available literature related to this topic, it is evident that research pertaining to counterterrorism effectiveness can be divided into two categories: evaluation of counterterrorism measures and literature reviews on the evaluation of counterterrorism measures. Researchers conducting evaluations of existing counterterrorism measures tend to focus their attention on a small selection of policies, particularly those that are subjected to controversy, such as military interventions and the use of force, targeted killings via drone strikes, expansion of surveillance methods, increased airport security $^{75}$. The handful of literature reviews that exist to date echo similar findings each time the literature on counterterrorism effectiveness is limited and does not provide a consensual evaluative method for determining the effectiveness of counterterrorism strategies.

It is almost standard for all the literature on terrorism to begin with a debate centered on the ambiguous definition of terrorism. Even though this approach seems overdone, it is compulsory to deliberate the operationalization and conceptualization of "terrorism" as an action, and "terrorist" as a descriptive term associated with an individual and group. In Beatrice de Graaf's book Evaluating Counterterrorism Performance, she states that in order to evaluate the efficacy of counterterrorism measures, it is necessary to provide a definition that will subsequently allow for indicators to be selected for evaluating the legal instruments and policies associated with $\mathrm{CT}^{76}$ De Graaf declares the importance of defining "terrorism", but does not set a standard definition for the purposes of her research; instead, she outlines the most commonly

\footnotetext{
${ }^{73}$ Mannes 2008; Muro 2016; Van Um and Pisoiu 2011; Van Um and Pisoiu 2015; Van Dongen 2011

${ }^{74}$ Cronin 2013; Long 2010; Price 2012

${ }^{75}$ Van Um and Pisoiu 2015, 231

${ }^{76}$ Beatrice De Graaf, Evaluating Counterterrorism Performance, New York: Routledge, 2013. 5.
} 
used definition of terrorism ${ }^{77}$, followed by definitions provided by prominent terrorism researchers. ${ }^{78}$ In order to mitigate the confusion associated with the ambiguity of the term, Oldrich Bures applies the EU's common definition of "terrorism" in his book, $E U$ Counterterrorism Policy: A Paper Tiger ${ }^{79}$. This definition was elaborated in the binding Council Framework Decision in June 2002, and it consists of three parts that examine the context of an action, the aim of an action, and the specific acts being committed (see Annex $\mathrm{C}$ for the Council Framework Decision, in which the definition is outlined in Article 1).

The articles examined for this literature review analyze the strategies, legal and policy instruments, and institutional designs that contribute to the existing counterterrorism measures. Although the existing subject matter either focuses on the internal or external dimensions of counterterrorism (i.e. the civil or military means for combatting terrorism), this research did not come across any literature that attempts to answer how these two dimensions can converge at the member state level to contribute to the EU's supranational counterterrorism efforts. Bruno

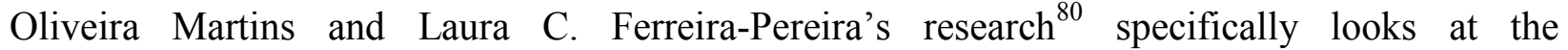
intergovernmental approaches for fighting terrorism, particularly by assessing how the EU's CSDP can be conceived as a tool to fight terrorism. The authors acknowledge how terrorism has traditionally been viewed as an internal battle and that it has been addressed by the Justice and Home Affairs sector of the EU. With that said, the authors identify that the integral problem is that the CSDP is not being utilized in counterterrorism measures even though all the EU's

\footnotetext{
${ }^{77}$ De Graaf (2013) states that the widely used definition of terrorism is derived from the American Federal Bureau of Investigation's definition that surfaced in the 1980s. They define terrorism as, "the unlawful use of force and violence against persons or property to intimidate or coerce a government, the civilian population, or any segment thereof, in furtherance of political or social objectives".

${ }^{78}$ One definition that De Graaf $(2013,5-6)$ uses is one by Bruce Hoffman, who stresses that terrorism is both a "tactic and strategy" and that terrorism is aimed at the deliberate creation and exploitation of fear through violence or the threat of violence in the pursuit of political change.

${ }^{79}$ Bures, Oldrich. EU Counterterrorism Policy: A Paper Tiger? Surrey, UK: Ashgate Publishing Ltd., 2011.

${ }^{80}$ Martins, Bruno Oliveira and Laura C. Ferreira-Pereira. "Stepping inside? CSDP missions and EU counter-terrorism." European Security 21:4 (2012): 537-556.
} 
existing frameworks and strategies on counterterrorism refer to the CSDP as a critical component to the fight against terrorism. For this reason, they find that counterterrorism policies in the EU have been "ineffective" 81 , and thus their study attempts to fill the gap in the literature by exploring this external dimension through policy and content analysis.

In contrast to Martins' and Ferreira-Pereira's external examination, Stephen Sloan ${ }^{82}$ and Tore Bjørgo ${ }^{83}$ maintain their focus on the internal dimensions of counterterrorism. Bjørgo challenges the current internal model of counterterrorism that is almost exclusively based on crime prevention, and he identifies nine preventative mechanisms ${ }^{84}$, all while arguing that military measures are not the right direction for terrorism prevention. Overall, his conclusions are based on the idea that states should be focusing on "softer" approaches for combatting terrorism as opposed to continuing with "harder" approaches, such as increasing military means and an external presence. Compared to Bjørgo's holistic analysis on counterterrorism, Sloan examines the internal dimension while focusing on the role of intelligence because he finds that intelligence is the "heart of countering terrorism". ${ }^{85}$ Sloan argues that it is "vital" that intelligence capabilities are refined and extended beyond the local level. He uses the US as a case study and finds that first responders for counterterrorism operations should be at the local level, but ultimately there needs to be integration on all levels in order to develop proactive counterterrorism measures. To come to his conclusions, Sloan analyzes the different levels of the intelligence institutions in the US (municipal, state, federal) and examines the policies and

\footnotetext{
${ }^{81}$ I say "ineffective" because Martins and Ferreira-Pereira do not define their criteria for effectiveness when it comes to CT. However, they do identify that the EU does not specify clear counterterrorism objectives in their policies and this contributes to the lack of counterterrorism evaluations.

${ }^{82}$ Sloan, Stephen. "Meeting the Terrorist Threat: The Localization of Counterterrorism Intelligence." Police Practice and Research 3:4 (2002): 337-345.

${ }^{83}$ Bjørgo, Tore. "Counter-terrorism as Crime Prevention: A Holistic Approach." Behavioural Sciences of Terrorism and Political Aggression 8:1 (2016): 25-44.

${ }^{84}$ Bjørgo's preventative mechanisms are: building normative barriers against terrorism, reducing radicalization and recruitment, deterrence, disruption, incapacitation, protecting vulnerable targets, reducing benefits to terrorists, reducing harm, and facilitating disengagement from terrorism

${ }^{85}$ Sloan, "Meeting the Terrorist Threat," 2002, 337.
} 
memorandums that demonstrate any signs of integration and collaboration. Although Sloan's article is slightly more dated than some of the other material reviewed, in addition to the use of the US as his sole case study, the findings of his research are applicable to the European case because of the current debate to strengthen European intelligence capabilities to combat terrorism. $^{86}$

Overall, the sample of literature that has been referred to represents the broader picture of the available literature on the EU's counterterrorism policies (at the EU level and the member state level). Researchers have focused their attention either on internal dimensions or on external dimensions, and there seems to be a lack of research directed at attempting to converge the efforts of the different security services to combat domestic and international terrorism. With this in mind, I am hoping to contribute to the literature by assessing in what ways can counterterrorism policy, the legal instruments, and the institutional frameworks develop in order to allow for the internal and external security services to collaborate and converge their strategies.

\footnotetext{
${ }^{86}$ These debates have been ongoing for several years now, and have recently resurfaced in the wake of the terrorist attacks in Belgium on 22 March 2016. The European Parliament brought up the issue again on 11 April 2016 and several Members of the European Parliament (MEPs) have pointed toward the need for a European intelligence community that extends beyond the nonauthoritative capabilities of Europol, or of the voluntary role of the European Situation Centre (SITCEN).
} 


\section{CHAPTER IV: THE EU AND COUNTERTERRORISM}

"4. The revolutionary despises public opinion. He despises and hates the existing social morality in all its manifestations. For him, morality is everything which contributes to the triumph of the revolution. Immoral and criminal is everything that stands in its way." - Sergey Nechayev

\section{A. ISSUE}

The evolution of our media consumption and the media's role in securitizing political events has lead the general population to believe that the threat of terrorism is greater in the $21^{\text {st }}$ century than the prior generations. However, Europeans are familiar with terrorism and its various "waves". EU member states themselves have tackled anarchists, separatists, the far-left and far-right, and jihadists, all of whom have conducted acts of violence to achieve their respective political motivations. With Europe's extensive history of political violence and terrorism, one would conclude that effective measures have been adopted based on historical experience and based on more recent factors that have resulted from the EU's deeper integration (e.g. Open borders, visa-free travel, the ease and inexpensiveness of changing mobile phone numbers and switching out device). Although the EU has taken these factors into account, the issue of terrorism in Europe is not diminishing, and the EU's counterterrorism measures remain ineffective (for the reasons outlining this assumption, please see chapter 1).

The purpose of this chapter is to revisit this thesis' research question, why are the EU's counterterrorism measures ineffective? Using this question as the foundation of this research, this chapter will examine three aspects of the EU's battle against terrorism: legislative instruments (including policies, strategies, and EU legislation in the form of regulations, directives, and decisions); institutional actors; and intelligence sharing. These fragments will be 
analyzed and discussed separately to determine the effectiveness of counterterrorism in the EU. In doing so, this chapter attempts to continue this dissertation's argument that the EU's counterterrorism measures are ineffective because there is a severe lack of harmonization of policies or institutions, making it difficult to establish a unified front to combat terrorism in Europe, and the existing measures fail to address the PREVENT pillar of the EU Counterterrorism Strategy (2005).

The measures assessed in this chapter include those that have been enacted by the EU between 2001 and 2016; the measures assessed to determine the Union's effectiveness were selected by applying the methodology outlined in Chapter II. Because of the vast number of legal instruments designed and developed by the EU, only binding legal instruments will be analyzed, which include regulations, directives, and decisions. Legislative decisions fall under two categories: framework decisions and implementing decisions. Framework decisions were created by the Amsterdam Treaty (1997) and they applied to the former Third Pillar of the EU (pertaining to the area of Judicial and Police Cooperation). Framework decisions were applied similarly to directives ${ }^{87}$; however, the principle of direct effect ${ }^{88}$ could not be employed, therefore the European Court of Justice could not impose consequences on member states for not transposing the legislation into their national laws. However, with the introduction of the Lisbon Treaty (2009), Framework Decisions were abolished. The EU can now enforce hard law

\footnotetext{
${ }^{87}$ Directives are binding on the objective to be achieved in the directive and it aims to harmonize the legislation of the member states. It is up to each member state to determine how the directive is to be implemented in national legislation or other national regulations (member states will often produce an action plan that outlines the path for implementing a directive into national law). Decisions are binding only for the person or persons to whom the decision applies. Regulations are binding and apply simultaneously and in the same way in all member states.

88 The principle of direct effect was first established by the Court of Justice of the European Union (CJEU) in Van Gend en Loos v. Nederlandse Administratie der Belastingen, and it was expanded into vertical and horizontal direct effect in Defrenne $v$. SABENA (No. 2). Vertical direct effect concerns the relationship between EU law and national law - specifically, the state's obligation to ensure its observance and its compatibility with EU law. Horizontal direct effect concerns the relationship between individuals (including companies). If a certain provision of EU law is horizontally directly effective, then citizens are able to rely on it in actions against each other.
} 
(including directives, implementing decisions, and framework decisions) through the EU's ordinary legislative procedures with regards to criminal justice matters.

In addition to the legislative policies that are analyzed in this chapter, EU institutions and agencies that play a role in counterterrorism will also be examined. Examining these institutions is necessary to understand the overlapping and fragmented role the EU has taken in counterterrorism, and where these gaps can be filled by harmonizing policies and establishing a single intelligence agency, or at the very least, an intelligence sharing alliance that can be compared to the intelligence sharing pact, the Five Eyes, which consists of the US, UK, Canada, Australia, and New Zealand.

Prior to delving into the policy analysis, it is necessary to situate the EU's experiences with political violence, and specifically jihadist extremism, by providing historical background information. The following section aims to ensure that the reader understands how jihadism became prominent in Europe, and which persistent issues in the EU are feeding into the jihadist phenomenon.

\section{B. BACKGROUND ON TERRORISM AND JIHADIST EXTREMISM IN} WESTERN EUROPE/THE EU

Europe's efforts against terrorism and political violence is hardly a new phenomenon scholars have deliberated the potential identification of various terrorist groups that date back to the $1^{\text {st }}$ century. The notion of modern terrorism predicates itself during the Reign of Terror in France (1793-1794), a period of approximately eleven months where the executive government of Revolutionary France used extreme and violent intimidation tactics to ensure compliance with the state. Unlike our contemporary understanding of terrorism existing as violent antigovernment and anti-state movements, these early records of terrorism during the Reign of 
Terror established the idea of the systemic use of terror as policy by monarchs and their governments. ${ }^{89}$ Thus, terrorism was conflated with "state terrorism" until the emergence of nongovernmental groups participating in acts of terror against the state in the late $19^{\text {th }}$ century (see the descriptions on anarchist terrorism below).

Europe has struggled with several "waves" of terrorism for well over a century now. As referred in Chapter II of this dissertation, David Rapoport developed the Wave Theory within terrorism studies to describe the dominant features of each generation's principal terrorist threat. Rapoport identifies four waves that correspond with the various objectives and motivations that have served as catalysts for mobilizing the innumerable terrorist organizations ${ }^{90}$. Despite Rapoport's occasional remarks on the impact of these waves in non-European countries, his research ultimately ends up producing Euro-centric results that define the terrorist threats experienced throughout Western Europe since the late $19^{\text {th }}$ century. The Wave Theory provides a coherent breakdown of Europe's experiences with terrorism, that is now widely used within terrorism studies, by pinpointing these four waves: Anarchist, Anti-colonialist, New Left, and Religious. Terrorism scholars have since debated their own versions of a "fifth" wave, such as Jeffrey Kaplan's claims that Fifth Wave groups have no catalytic events and they are developed from previously existing movements ${ }^{91}$; or Peter Neumann's Fifth Wave depicted as the "New Jihadists", growing out of the fourth wave's "religious" movements and mobilizing a younger generation. ${ }^{92}$ While scholars deliberate what a fifth wave of terrorism will produce, Rapoport's four waves continue to serve as a backdrop to dictate Europe's history of terrorism.

\footnotetext{
${ }^{89}$ Verena Erlenbusch, "Terrorism and revolutionary violence: the emergence of terrorism in the French Revolution," Critical Studies on Terrorism 8 no.2, 2015, 206.

${ }^{90}$ David Rapoport, "The Four Waves of Modern Terrorism," in Attacking Terrorism: Elements of a Grand Strategy, eds. Audrey Kurth Cronin, James M. Ludes. 2004. PUBLISHER. 46-73.

${ }^{91}$ Jeffrey Kaplan, Terrorist Groups and the New Tribalisms: Terrorism's Fifth Wave, New York: Routledge 2012.

${ }^{92}$ Peter R. Neumann, Radicalized: New Jihadists and the Threat to the West, London: I.B. Tauris 2016.
} 
First Wave: Anarchist Terrorism

Before terrorism was religious and transnational, it was highly political and predominately domestic. A century after state terrorism rippled throughout France and Europe, non-governmental groups began to mold our modern understanding of terrorism as political violence, wherein assassination of political figures was the primary strategy of choice. Although it is fueled by domestic political situations, anarchist terrorism is viewed as the first strand of international terrorism because of its spread to other countries. Its primary objective is aiming to create a free, stateless society.

Rapoport and his contemporaries highlight that anarchist terrorism has its roots in Russia, resulting in the assassination of Czar Alexander II by the anarchist terrorist group Narodnaya Volya (English: People's Will), but earlier writings supporting physical violence to incite mass rebellion can be linked to Italian socialist thinker and revolutionary Carlo Pisacane (1818-1857). Pisacane's work, Il Testamento Politico (English: The Political Testament, 1857), was the foundation for anarchism's defining motto and political action, where he writes that "ideas come from deeds and not vice versa; and the people will not be free because they will be educated, but they will soon be educated when they are free". ${ }^{93}$ His argument, which is also developed in his book La Rivoluzione (English: The Revolution, 1857), was that violence is a necessary element to draw attention to a cause, but it was also necessary to inform, educate, and mobilize the masses to lead a revolution against the [capitalist] state. ${ }^{94}$ In more simpler terms, this meant that one single attack can create more propaganda than passing out pamphlets. In 1881, the delegates at the International Anarchist Congress adopted "Propaganda by the Deed" (terrorism) as the

\footnotetext{
${ }^{93}$ Carlo Pisacane. Il Testamento Politico. Italy 1857. Accessed online 5 June 2017:

http://www.reteccp.org/biblioteca/disponibili/demos/demoesocial/garibaldi/pisacane/testamentopisacane.pdf

${ }^{94}$ Carlo Pisacane. La Rivoluzione. Italy 1857. Accessed online 5 June 2017:

http://www.bibliotecamarxista.org/pisacane\%20 carlo/Carlo Pisacane - La Rivoluzione.pdf
} 
primary strategy to achieve their goal for a stateless society. This foundational and fundamental idea has been used as a critical proponent to propel individuals and organizations to plan and carry out acts of terrorism.

While there were some anarchists in Pisacane's time that believed revolution could be achieved through peaceful means (notably Belgium's Pierre-Joseph Proudhon [1809-1865]), it was Pisacane's emphasis on the use of violence that categorized anarchy as a "type" of terrorism. Toward the end of the century in the 1880s, it was the Russian anarchists that could build upon the earlier ideas of anarchy and revolution. The French Revolution may have introduced the term “terror" into our vocabulary, but it was the Menshevik writer and revolutionary, Vera Zasulich, who famously declared "I'm a terrorist, not a killer" after shooting a Russian police commander, Colonel Fyodor Trepov, who was known for his suppression of the Polish. The incident made Zasulich famous amongst Russian populists and Radicals.

Sergey Nechayev (1847-1882), a Russian social revolutionary associated with the Nihilist movement, could be viewed as the author of one of the first manifestos on terrorism, Catechism of a Revolutionary ${ }^{95}$. The points that Nechayev makes within his manifesto reveal his fundamental belief that destruction and terror are necessary components for a social revolution to dismantle the state and government, thus establishing Nechayev's main slogan: "the ends justify the means". For Nechayev and other anarchists, terrorism was a strategy, not an end goal. Compared to contemporary "manifestos" and writings from terrorist leaders (such as Osama Bin Laden's Military Studies in the Jihad Against the Tyrants, Georgas Grivas' Guerrilla War, Carlos Marighella's Mini-Manual of the Urban Guerrilla, and even the manifestos of far-right

\footnotetext{
${ }^{95}$ Catechism of a Revolutionary is divided into three parts: Duties of the Revolutionary toward Himself; Duties of the Revolutionary toward his Comrades; and Duties of the Revolutionary toward Society. Each chapter of this dissertation opens with a criterion from Duties of the Revolutionary toward Himself.

Sergey Nechayev. Catechism of a Revolutionary. 1871. Accessed on 4 June 2017.

https://www.marxists.org/subject/anarchism/nechayev/catechism.htm
} 
lone actors Dylan Roof and Anders Behring Breivik), the one similarity that can be extracted from the collective is that they all refer to the experiences of their friends and enemies because they seek to make their brand of terrorism more efficient than their predecessors. ${ }^{96}$ Anarchist terrorism found its roots in Russia, but within a decade, the extremist ideology spread to Western Europe .

With the proliferation of anarchist terrorism outside of Russia, the 1890s turned into the "Golden Age of Assassinations". The anarchists from this first wave directed their assassinations at hard targets, which would establish a trend for future political terrorist movements. In the span of a decade, anarchists were responsible for many high-profile assassinations, including killing the French President Marie François Sadi Carnot (1894), Spanish Prime Minister Antonio Cánovas del Castillo (1897), the Empress Elizabeth of the Austro-Hungarian empire (1898), and King Umberto I of Italy (1900). The anarchists are important to discuss in the context of counterterrorism and the motives of terrorist organizations because they developed some of the original doctrines and strategies that are still elaborated upon by terrorist groups today.

Second and Third Waves: Anti-Colonialist and New Left Terrorism

Before modern day, mujahideen and jihadist extremists identified themselves as "freedom fighters", the label being used to describe anti-colonial terrorists of the Second Wave of international terrorism. The catalytic event that prompted this new wave was the Treaty of Versailles, which not only brought World War I to its end, but also resulted in the breakup of many European empires and the establishment of the League of Nations. The non-European portions of the empires were deemed unfitting for independence and they became "mandates" under the League of Nations, thus spurring a wave defined by national self-determination.

\footnotetext{
${ }^{96}$ Rapoport, The Four Waves of Modern Terrorism, 49.
} 
Terrorist activity during the anti-colonial wave was crucial for the establishment and independence of many states during this period, including but not limited to Ireland (through the various degrees of success under the Irish Revolutionary Army [IRA]), Israel, Cyprus, and Algeria.

This second wave of terrorism brought upon changes to the strategic use of terror during the early $20^{\text {th }}$ century. Unlike Zasulich and other anarchists in the decades before, anticolonialists sought to change the rhetoric surrounding their use of physical violence to incite change. They no longer wished to be labeled, or self-identified, as "terrorists" due to the negative connotation surrounding the word; anti-colonialists began to refer to themselves as "freedom fighters", a term that managed to catch on toward the end of the wave, when the UN adopted the terms within their debates.

Besides rhetoric, anti-colonialists also reformed terrorism strategies. The anti-colonialists moved away from assassinating high-profile figures to spread their message, and instead they began to focus on eliminating police forces and implementing guerrilla-like tactics against troops who would replace police forces. The anti-colonialists believed that the armed forces sent to replace police forces would be less organized and unable to instill order within society. The League of Nations attempted to contain the spread of this new international terrorism by drafting up conventions (one of them to establish an international court for terrorism) but neither of these conventions came through; both Italy and Hungary continuously blocked attempts for anti-terror cooperation. By the time the UN was formed as the successor to the League of Nations in 1947, it had inherited the League of Nation's "mandates" that were seen as hubs for terrorism. By the 1960s, a wave of decolonization brought down empires and introduced dozens of newly independent states. 
As this second wave of terrorism rescinded, a third wave emerged as a reaction to increased internationalism, and it became more prominent with the start of the Vietnam War in 1955. This third wave of "New Left" terrorists were the contemporary anarchists - it was a new generation of youth disenchanted with the existing system and the West's international hegemonic role. They viewed themselves as vanguards for the developing world, leading to the establishment of some of the most infamous European terrorist groups: Germany's Red Army Faction (RAF), Italy's Brigate Rosse (English: “The Red Brigades”), and France's Action Directe (English: "Direct Action"). Like their anarchist forefathers, the third wave was characterized by radicalism and nationalism, prompting ethno-nationalist groups such as the Basques, Kurds, and the Irish to also continue their movements from the second wave.

New Left terrorists also brought back some of the terror strategies that fell out of popularity during the second wave; namely, assassination of theatrical targets. During this period, the IRA killed the former British Ambassador to Ireland (1976), Lord Mountbatten (1979), and they made attempts to kill former Prime Ministers Margaret Thatcher (1984) and John Major (1991). The Euskadi Ta Askatasuna (English: Basque Homeland and Liberty [ETA]), a leftist Basque ethno-nationalist terrorist organization, was behind the assassination of the former Spanish Prime Minister Luis Carrero Blanco (1973). The third wave's logic for assassinations was different than the first wave's. During the first wave, anarchists assassinated targets who held public office, but the third wave conducted assassinations as "punishments". Beyond the reintroduction of assassinations, the third wave was defined by hostage crisis; in a span of three decades, over 700 hijackings had taken place. Kidnappings were especially prominent in Italy, where the BR kidnapped and murdered the former Italian Prime Minister Aldo Moro in 1975. 
Europe's experiences with various forms of international terrorism in the $20^{\text {th }}$ century led to eventual state cooperation for counterterrorism efforts, namely the introduction of the TREVI (Terrorism, Radicalism, Extremism, Violence International) Group. This group was composed of the twelve European Community (EC) members at the time and was based on intergovernmental cooperation, meaning it excluded participation from the main EC institutions (the European Commission, the Council of the EU, and the European Parliament). Despite the initial concern with international terrorism, the group slowly started expanding their focus to include other cross-border crimes within the EC. The TREVI Group is an important actor in European security because it provided the foundation for a formalized and cooperative policing agency. ${ }^{97}$ However, problems with extradition created issues for European cooperation as several states refused to extradite suspected and convicted terrorists back to their home states for trial.

Fourth Wave: Religious Wave and the Spread of Jihadist Extremists in Europe

The first three waves created strategies and experiences for this new wave of religious fundamentalists to build themselves upon. The religious wave has primarily been centered around radical Islamic fundamentalism, which is the idea that the movement's followers seek to eliminate their subjective understanding of "corruptive" non-Islamic influence. ${ }^{98}$ For this dissertation, radical Islamic fundamentalism is referred to as jihadist extremism, to prevent conflating Islam with extremist behaviour, as there are "Islamic fundamentalists" who believe in the ideology but do not interpret the teachings literally and they do not believe in the use of physical violence and terror to achieve this goal. ${ }^{99}$ This subsection will illustrate how modern-

\footnotetext{
${ }^{97}$ Tony Bunyan, "Trevi, Europol and the European State," State-watching the New Europe, 1993, 1

${ }^{98}$ Rapoport, "The Four Waves of Modern Terrorism," 2004, 61.

${ }^{99}$ Europol, 2016 Terrorism Situation and Trend Report, 52-53.
} 
day jihadist extremism in Europe developed largely because of Iranian and Saudi power struggles for diasporic influence among European Muslims.

Prior to the age of jihadist extremists, radical Islamic fundamentalist movement originated in 1924 in Turkey, where Mustafa Kemal Attatürk's secular republican forced launched a campaign against Westernization in Turkey. This anti-Western attitude would soon become a distinctive quality within the fundamentalist and following extremist movements. However, the religious wave did not truly manifest itself until the 1980s. Rapoport identifies three international events in 1979 that facilitated the emergence of the jihadist extremists that would define this wave: the new century per the Sunni ${ }^{100}$ Calendar, the Iranian Revolution, and the Soviet invasion of Afghanistan. For Sunni Muslims, 1979 was an important year to start with as a new century began. The masses flooded to Mecca in Saudi Arabia for the annual pilgrimage, which resulted in 10000 deaths that year. In the Shiite world, the Iranian Revolution occurred as a disintegration of the Shah's secular state, eventually inspiring Iranian and Shiite terror movements outside of Iran (particularly in Iraq, Saudi Arabia, Kuwait, and Lebanon). The Shiite terrorists, inspired by the self-Martyrdom tactics of the medieval Assassins, introduced suicide bombing in their attacks within Lebanon. The fourth wave would be defined by the cheap and distinctive strategy of using suicide bombers to spread its message. Finally, the Soviet invasion in Afghanistan led to Sunni volunteers coming to support Afghanistan and contributing to the resistance. Following the US's efforts to drive out the Soviets out by 1989, the former Soviet lands with large Muslim populations became important new fields for Islamic rebels. This included Chechnya, Uzbekistan, Kyrgyzstan, Tajikistan, Azerbaijan, but it would also include the Islamic forces that ignited within Bosnia and Herzegovina. ${ }^{101}$

\footnotetext{
${ }^{100}$ Sunnis make up one of two major Islamic denominations, the second being the Shiites.

${ }^{101}$ Pargeter, The New Frontiers of Jihad, 2009, 22-26.
} 
Outside of the Middle East, the Sunni-Shiite divide ${ }^{102}$ manifested itself within the Muslim diaspora across Western Europe, as Saudi Arabia and Iran competed to spread their external influence, which sparked a rise of political Islam in the 1980s. Prominent ultra-orthodox Imams and Sheikhs in Europe took advantage of the Islamic consciousness that swept across the diaspora because of the Iranian Revolution and the calls for volunteers to participate in the Afghan jihad throughout the 1980s. These community leaders had the opportunity to spread their message and propaganda because of the influx of funding coming from Saudi Arabia and Iran for building and developing cultural centres and mosques. With the largest population of Muslim immigrants, France went from having 136 registered mosques in 1978 to 766 in 1985. Likewise, the UK also experienced growth in registered mosques in the same timeframe (from 51 to 329). In addition to funding various centres and mosques, the rival powers also invested their money into political and charity organizations that would play a role in propagating specific interpretations of Islam and promoting dawah work (preaching Islam often through community work) and the ummah (Islamic community). One of the primary beneficiaries of Saudi funding was Egypt's Muslim Brotherhood (MB) ${ }^{103}$ and their branches in Europe, whose leaders had more freedom and mobility to preach than was expected. This allowed for Islamic organizations to thrive in the 1980s, because Saudi-financed groups like the MB sought to promote the ummah and a new era of Islamic consciousness. ${ }^{104}$

The emergence of political Islam in the 1980s and the emphasis on the Islamic consciousness within the diaspora in Europe, due to competing Sunni-Shiite (read: Saudi and

\footnotetext{
102 The schism between Sunni and Shiite Muslims goes back almost 1400 years, and the differences lie in the rightful leaders of Islam after the death of the Prophet Muhammed. However, the schism has evolved from a religious divide into a political divide that has Iran and Saudi Arabia wrestling for regional power and influence.

${ }^{103}$ First articulation of political Islam. The Muslim Brotherhood are a controversial group of self-described pacifists that are split from Saudi reformists. They have refrained from the use of violence (maintaining distance from jihadist extremists) and instead they opt for a bottom-up and education approach that preaches simple conservative Islamic ideas, allowing for it to be spread easily outside of Egypt.

${ }^{104}$ Pargeter, The New Frontiers of Jihad, 2009, 26.
} 
Iranian) interests, were foundational for three interconnected events that would revive the Islamic consciousness in the late 1980s and early 1990s. This newfound Islamic consciousness would lead to the spread of Europe's jihadists. The three events that took place were: (i) The Rushdie Affair in 1988; (ii) the end of the Soviet-Afghan War in 1989; and (iii) the Bosnian war in the early 1990s.

The Islamic consciousness began to dip again toward the end of the decade, until the "Rushdie Affair" reintroduced the fragility of the concept of the ummah. The affair stemmed from the publication of Salman Rushdie's novel, The Satanic Verses (1988), which was inspired by the life of the Prophet Muhammed. The book's publication led the European Muslim diaspora to accuse Rushdie of blasphemy; and in 1989, the former Supreme Leader of Iran, Ayatollah Khomeini, took advantage of the heightened Islamic consciousness and tried to spread Iranian and Shiite influence by issuing a fatwa ${ }^{105}$ ordering Muslims to kill Rushdie. Khomeini viewed this crisis as an opportunity to challenge the Saudi hegemony in the Middle East and its influence on European Muslims. The Saudi's response to Khomeini's fatwa was announcing that Rushdie should not be killed automatically, rather, he should stand trial at the Islamic court. Across Europe, book burnings were organized, which shocked Europeans because it went against their liberal beliefs and values.

The Rushdie Affair's effects on European Muslims created divisions caused by the clashing of liberal European values and conservative Islamic values. Muslim communities in Europe began to feel as if their values and viewpoints were not compatible in Europe, and they felt attacked within their home countries. ${ }^{106}$ The burning of The Satanic Verses was not solely about religious matters anymore; it offered a way for "young and disaffected" Muslim

\footnotetext{
${ }^{105}$ In Islamic faith, a fatwa is a non-binding but authoritative legal opinion.

${ }^{106}$ Pargeter, The New Frontiers of Jihad, 2009, 27.
} 
immigrants to express their general dissatisfaction with life in Europe and their frustrations about being a minority community in their host countries. ${ }^{107}$ Interestingly enough, one trend that began with the Rushdie Affair that can be seen with present day European jihadists is that these book burnings and protests primarily involved young Muslims who were unable to recite the Quran, flouted traditional Muslim taboos on sex, drinking, and drug use - but they felt resentful about the treatment of Muslims in Europe, and they were disenchanted with the left-wing politics within Europe. Ultimately, Islam became a "rallying cry" for disenchanted youth. ${ }^{108}$ This trend, which will be explored more further into this dissertation, has become prominent in recent years as researchers and analysts explore the "crime-terror nexus", which involves disenchanted youth with criminal records that turn to Islam as a way to justify their already radical behavior.

The two events following the Rushdie Affair, the end of the Soviet-Afghan War and the Bosnian War, are closely linked to a single phenomenon: mujahideen fighters returning from Afghanistan seeking a new jihad to fight for, and looking to the Bosnian War as their new calling. The Soviet-Afghan War in the 1980s established the first holy struggle, the Afghan Jihad, drawing in Islamists to fight in the Afghan resistance. ${ }^{109}$ Islamists were able to move easily between Afghanistan and Europe because the Afghan resistance had the support from the US's Central Intelligence Agency (CIA) and the Saudis, and the resistance had various offices across Europe, including an information office in Paris, France. The Afghan Jihad managed to recruit fighters and volunteers because of the Sheikhs and Islamic scholars that came to Europe throughout the 1980s to alert the Muslim communities about what was going on in Afghanistan and Palestine, invoking a sense of a sadness across that led to European Muslims seeking to

\footnotetext{
${ }^{107}$ Ibid., 26.

${ }^{108}$ Ibid.

${ }^{109}$ Evan Kohlmann, Al-Qaida's Jihad in Europe: The Afghan-Bosnian Network, New York, NY: Berg 2004.
} 
assist in the resistance. The end of the war and the displacement of mujahedeen fighters resulted in the development of major jihadist recruitment networks across Europe. ${ }^{110}$

With the veterans searching for a new battlefield for jihad, several opportunities presented themselves in the early 1990s. Conflicts in Chechnya, Tajikistan, and Kashmir drew fighters to some degree, but only the conflict in Chechnya struck a chord with Arabs. Fighters who were displaced in Europe and granted asylum were war-hardened radicals - some of them settled down, while others identified the Bosnian War as their new battlefield. ${ }^{111}$ The so-called Bosnian Jihad became the Rushdie Affair of the 1990s; once again, Iran and Saudi Arabia raced to spread their influence. Both sides participated in assisting Bosniaks (Bosnian Muslims) during the war, but the Bosniaks resented the Saudis and Iranians because they felt like pawns. The Iranians refused to work in areas without Saudis, and the Saudis tried to make secular Bosniaks abide by their ultra-orthodox rules. The Saudis and Islamists who came to Bosnia were shocked by the secularism in the country, and by the fact that the war was mostly about internal political struggles rather than a religious crusade. The Bosnian Jihad never had the same appeal as the Afghan Jihad, and eventually, fighters were discouraged from Bosnia and told to participate in the resistance in other countries (such as Eritrea and Somalia). Additionally, the appeal of the Bosnian Jihad dwindled because the Egyptian Afghan veterans had a larger contribution as they arrived "first" to the jihad, thus making it pointless for Saudi Arabia and Iran to stake any claims on influence in the region ${ }^{112}$.

Based on the events in 1979 and those following after, the emergence of jihadist and Islamic extremists in Europe can be drawn back to the Sunni-Shiite schism, which has actually become a power struggle between Saudi Arabia and Iran that extended outside of the Middle

\footnotetext{
${ }^{110}$ Pargeter, The New Frontiers of Jihad, 2009, 33.

111 Ibid.

112 Ibid., 40.
} 
East. Three interconnected root causes for jihadist extremism in Europe can be identified as a result of these historic events:

1) The Islamic diaspora felt isolated in Europe: they never felt as if their values coincided with European values, leaving them to feel attacked within their host countries. ${ }^{113}$ However, this isolation extends beyond values. Muslim communities across Europe have been segregated as a result of poorly intentional urban planning that has led to social exclusion. ${ }^{114}$ Diasporas are often ghettoized, a phenomenon which extends beyond Arab and Asian Muslims, and applies to other nonEuropean/non-Caucasian groups.

2) European tolerance/ignorance: European values that uphold the freedom of expression have allowed for the freedom to practice any religion of one's choice. These values intend on emphasizing tolerance for multiculturalism, but this tolerance has actually turned into ignorance. European segregation has permitted selfsegregation among diasporas in Europe, resulting in groups preferring not to interact with their host countries and their host countries essentially ignoring their existence. This allowed for Saudi Arabia and Iran to try and influence diasporas and permitted their investments into building mosques and cultural centres where radical ideas would eventually flourish.

3) Saudi/Iranian funding for Islamic communities in Europe: The second root cause extends into the third source of jihadist extremism in Europe. The Saudi/Iranian funding provided to mosques and community centres in Europe gave power to the

\footnotetext{
${ }^{113}$ Pargeter, The New Frontiers of Jihad, 2009, 31.

${ }^{114}$ Harvey Morris, "Europe's Cities: Gentrification or Ghettoization?" The New York Times, 21 August 2012 ; Yossra Hamouda, "When Subcultures Turn Into Ghettos: The Conceptual Ghetto and Oppression," Sociology and Anthropology 5 no.8, $2017,577-$ 583 ; Bassam Tibi, "Muslim Migrants in Europe: Between Euro-Islam and Ghettoization," in Muslim Europe or Euro-Islam, edited by Nezar AlSayyad and Manel Castel, New York: Lexington Books 2002: 31-52 ; Paul Lubeck, "The Challenge of Islamic Networks and Citizenship Claims: Europe's Painful Adjustment to Globalization,” in Muslim Europe or Euro-Islam 2002, 69-90.
} 
investors. They decided what was preached, and to an extent, this resulted in Saudi preaching of Wahhabism. Community leaders preached that this was preferable; Kalim Siddiqui, a British-Pakistani Islamic activist who defended Khomeini’s fatwa against Rushdie and founded the Muslim Parliament of Great Britain in 1989, declared that in order to survive as Muslims in Europe and Britain, communities should be developing their own institutions without any dependence on the British state, and these institutions should "plug into the global grid of the power of Islam". ${ }^{115}$ This exemplifies how some Islamist movements exploited European segregation, self-segregation, and external funding in order to continue isolating Muslim communities.

Jihadist extremism did not develop overnight in Europe, nor did it happen because of one sole event. These three general root causes demonstrate how the various factors and events have connected with one another in order to extract a small, yet destructive, fraction of the Muslim diaspora population. Arguably, extremism comes down to internal political and religious divisions that have exploited feelings of exclusion, isolation, and anger - feelings that are commonly heightened for young adults and adolescents because of natural biochemistry. Yet, when one analyzes Europe's counterterrorism measures, these root causes and emotional factors are hardly identified by governments. Addressing these issues would permit the development of more preventative counterterrorism measures, as opposed to reactionary measures that aim to neutralize terrorists and terrorist organizations.

The four waves of terrorism experienced in Europe are interesting to examine in the illustrations below, which highlight the cities impacted by terrorism between 1970 and the end of 2000, and the period examined within this paper, 2001-2015 (the data is extracted from the

\footnotetext{
${ }^{115}$ Kalim Siddiqui, speech on "Generating Power without Politics," 14 July 1990.
} 
Global Terrorism Database, which at the time of writing contained data for nearly 18000 terrorism incidents that took place between 1970 and the end of 2015 worldwide):

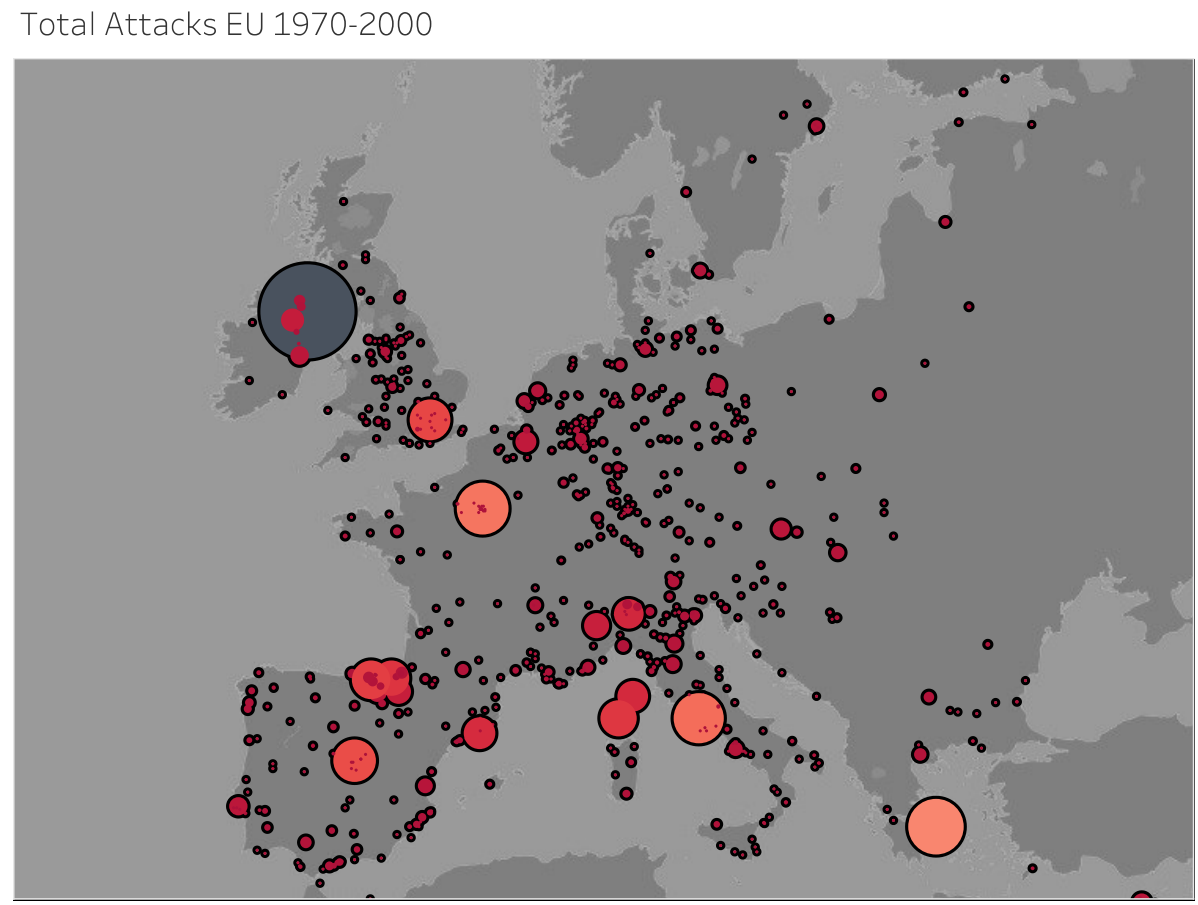

Map based on Longitude (generated) and Latitude (generated). Color shows sum of Number of Records. Size shows sum of Number of Records. Details are shown for Country Txt and City. The data is filtered on lyear, which ranges from 1970-01-01 to 2000-12-31. The view is filtered on Country Txt, which keeps 28 of 206 members.

Figure 4.1 Total Attacks in the EU Between 1970 and 2000. Map self-produced in Tableau using data provided by the University of Maryland's Global Terrorism Database. 


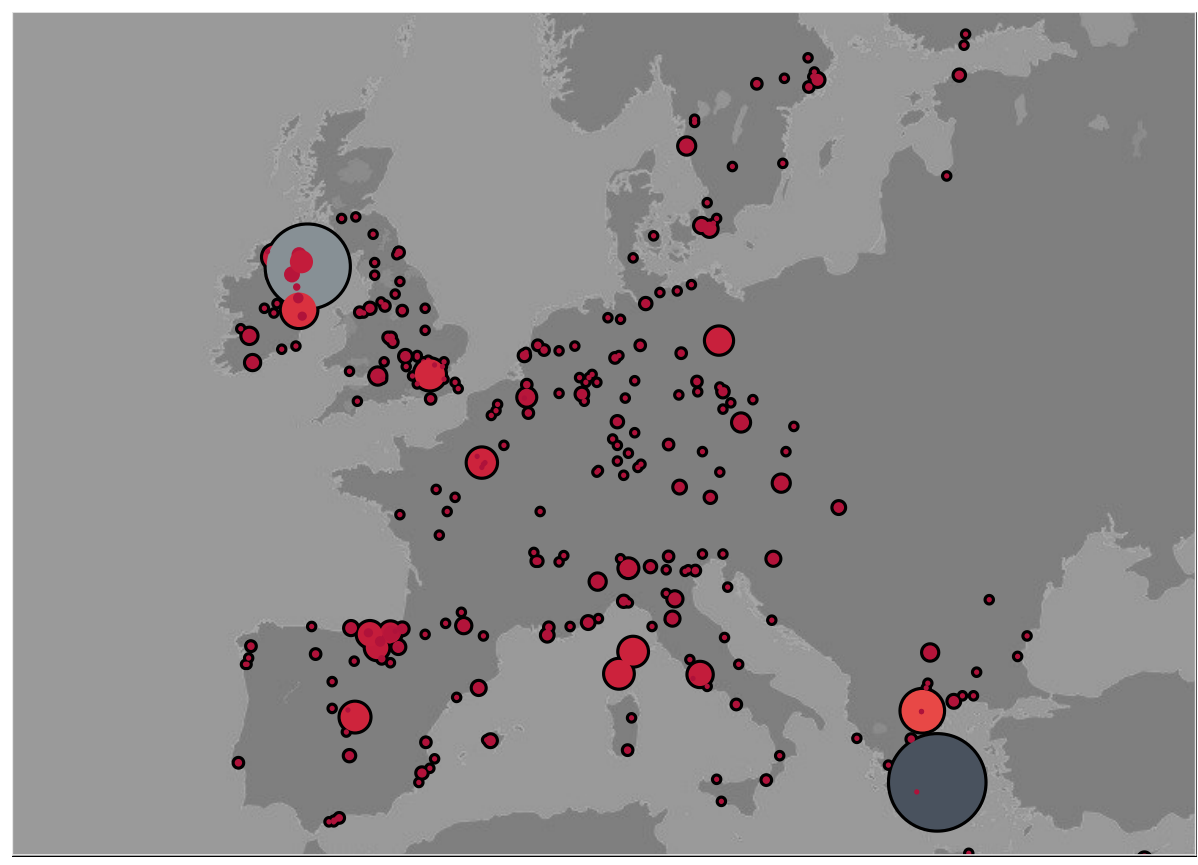

Map based on Longitude (generated) and Latitude (generated). Color shows sum of Number of Records. Size shows sum of Number of Records. Details are shown for Country Txt and City. The data is filtered on lyear, which ranges from 2001-01-01 to 2016-12-31. The view is filtered on Country Txt, which keeps 28 of 206 members.

Figure 4.2 Total Attacks in the EU Between 2001 and 2015. Map self-produced in Tableau using data provided by the University

\section{of Maryland's Global Terrorism Database.}

Both figures illustrate how widespread terrorism is throughout the EU, and they also exemplify which regions are consistently targeted, suggesting their experiences with terrorism are not solely with jihadist extremism in the post-9/11 world. Moreover, despite the number of incidents, only a small majority make it to the 24 -Hour News Cycle, and those tend to be largescale attacks that result in fatalities and injured individuals. Many attacks that occur are a result of far-left terrorism or ethno-nationalist terrorists, and they often result in only minor infrastructure damages and do not tend to have a significant impact on political processes (unless the attacks are frequently perpetuated by well-established groups and movements).

The following sections move toward this dissertation's institutional and policy analysis of counterterrorism measures in the EU. The assessments and analyses below are intended to support this dissertation's hypotheses. 
It is difficult to isolate the discourse on policy harmonization when institutional harmonization should be a by-product of forming cohesive counterterrorism measures across the EU. Institutional harmonization has received a special name because of the unique features it has acquired - Europeanization. In this policy domain, institutional harmonization would result in the convergence of formal and informal institutions toward a single model that would internalize European values and policy paradigms. ${ }^{116}$ Harmonization, whether it is of policy or institutions, is often discussed in the context of economic institutions for the purposes of trade liberalization; it is difficult to deny that the process of integration in the EU has far surpassed its role of a trading union. While most of the EU's complete competencies remain in the economic realm, the EU has taken strides in other policy fields (that all encompass economics in one way or another), including, but not limited to:

- Foreign, security, and defence policy (with its evolving CFSP and the CSDP, and the European External Action Services [EEAS], which serves as the EU's diplomatic service);

○ Humanitarian aid (through its Emergency Response Coordination Centre [ERCC] Disaster Risk Reduction, and European Voluntary Humanitarian Corps);

Law enforcement (Europol); and

- Military affairs (this includes the November 2017 announcement that the EU is moving closer to a joint military force after 23 member states signed on to jointly invest in equipment, research, and development).

\footnotetext{
${ }^{116}$ Anna Kolesnichenko. 2011. "Chapter 9: Institutional Harmonization in the Context of EU Cooperation with its Neighbour,” in EU Eastern Neighbourhood, ed. M. Dabrowski and M. Maliszewska. Berlin: Springer-Verlag Berlin Heidelberg, 2011.146. https://link.springer.com/content/pdf/10.1007/978-3-642-21093-8 9.pdf
} 
The EU has been striving for further political integration, but sensitivities surrounding national foreign, security, and defence policies have made it difficult to fully integrate in these areas. Various institutions have some intelligence sharing capabilities, but these capabilities are limited in power and they are voluntary in nature. Regarding the EU's counterterrorism efforts, it is sporadic and fragmented at best, and intelligence sharing is not mandatory nor is it extensively practiced (based on the information provided in unclassified literature). The chart below illustrates the various counterterrorism competencies held by numerous EU institutions:

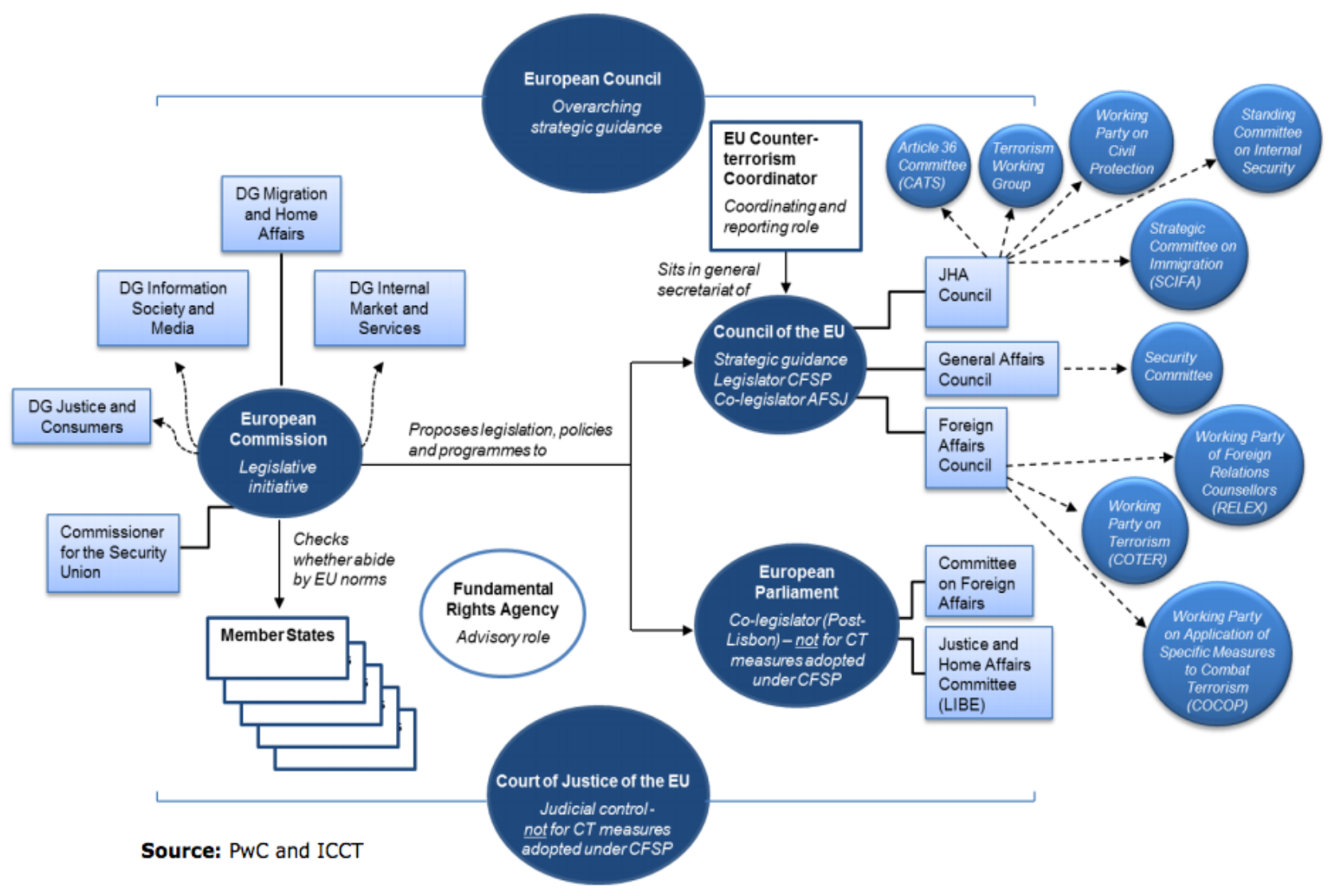

Figure 4.3 EU Counterterrorism Competencies. Source: International Centre of Counter-Terrorism's report "The European Union's Policies on Counter-Terrorism: Relevance, Coherence, and Effectiveness." 
Due to logistical constraints of this thesis, a breakdown of each of the above institutions will not be provided, but some of the primary institutions resembling some form of intelligence sharing capabilities will be explored below. The rest of this subsection aims to identify the gaps in EU intelligence sharing and to highlight why it is important for the EU to develop a single intelligence agency, particularly one that would (at minimum) focus on extensive counterterrorism intelligence sharing.

Internal security: Partial Intelligence Sharing within the EU?

Within the EU, there are already several institutionalized intelligence frameworks (categorized as either a formal or informal group) that have spurred some cooperation within the organization and its member states. Although none of them have an absolute legal mandate outlined in the 2009 Treaty of Lisbon, they are a stepping-stone to further intelligence cooperation, exemplifying that a common intelligence approach can be institutionalized within the EU. The existing institutions began with a platform based on sharing information about external threats (most commonly terrorism) through a forum, and eventually began to include the sharing of open source intelligence (OSINT). ${ }^{117}$ Formal components in the EU's intelligence sharing historically include the TREVI Group and its foundation for Europol; the EUMS and its correspondence with the Political and Security Committee; and the EU Joint Situation Centre/Intelligence Analysis Centre (SITCEN/INTCEN). In addition to these formal services, the EU member states have their own national intelligence services, likely with bilateral agreements

\footnotetext{
${ }^{117}$ OSINT refers to data collected from publicly available sources to be used in an intelligence context. In the intelligence community, the term "open" refers to overt, publicly available sources (as opposed to covert or clandestine sources). It is not related to open-source software or public intelligence.
} 
with both the EU and non-EU countries. ${ }^{118}$ Alongside these formal intelligence-gathering services, there are also several informal groups that meet on an ad-hoc basis to voluntarily share intelligence: the Berne Group, the Budapest Group, and the EUROSINT Forum. All these formal and informal institutions provide a strong foundation in which further cooperation and development can be built upon, to ensure further political integration.

\section{Background on Intelligence Cooperation in the EU}

The basis for intelligence cooperation in Europe began in 1976 with the establishment of the TREVI Group to combat terrorism threats. During the 1970s and 1980s, there were many demands for a common police institution in the EC, but it was not until 1991 when the German Chancellor Helmut Kohl called for the development of a European agency that would act similarly to the United States' FBI. Following the creation of the EU through 1992's Maastricht Treaty, a formalized police and security approach was institutionalized in the third pillar of the EU as Justice and Home Affairs. This third pillar provided the basis for police cooperation between member states to "combat terrorism, drug trafficking and other international crime", making an explicit reference to the establishment of the new EU police agency, Europol. At first, Europol was created as the European Drug Unit (EDU) in 1993, and by 1995 the Maastricht Treaty was amended to expand the EDU's powers. It was not until 1998 that Europol was fully established with complete legal mandate. Europol's main function is handling criminal intelligence through its law enforcement. Although they have no jurisdiction to arrest anyone, Europol conducts much of the criminal intelligence analysis within the EU borders. Europol's approach to tackling criminal networks is quite centralized, as member states have given them a

\footnotetext{
${ }^{118}$ James I. Walsh. "Intelligence-Sharing in the European Union: Institutions are not Enough,” in JCMS 44(3) 2006: 625-643. Jamesigoewalsh.com/jems.pdf
} 
central role through legal provisions in coordinating police cooperation in the fight against organized crime. ${ }^{119}$

The EUMS is part of the EU's common security and defense approach, which is considered an "integral part" to Europe's common foreign and security policy. ${ }^{120}$ The EUMS has a distinct Intelligence Directorate, whose mission is to analyze intelligence in order to provide early warnings and situation assessments. They work in conjunction with intelligence services of member states, as the respective country's officers in the EUMS receive national intelligence. This material is then processed in such a way that the contributing nation cannot be identified, and then distributed to the EU Military Committee (EUMC), the Political and Security Committee, and the EU Intelligence Analysis Centre (INTCEN). This demonstrates another partial intelligence sharing approach, because the member states anonymously cooperate to some extent to provide information on external threats. However, this cooperation only serves the High Representative of the Union for Foreign Affairs and Security/Vice-President of the Commission (HR/VP), as the EUMS and its directorates were formed to serve the HR/VP.

The Political and Security Committee (PSC), to whom EUMS intelligence analysts direct information, is one of the only references to intelligence sharing mechanisms mentioned in the TEU. Article 38 states that this committee is responsible for monitoring the international system and it must exercise political control with crisis management operations. Interestingly enough, there is no direct mention to actual intelligence sharing anywhere in the TEU/TFEU documents. Moreover, the PSC is not necessarily an intelligence co-operating mechanism necessarily - it is only able to function under the command of the HR/VP and their staff as long as intelligence is provided by the EUMS. Unfortunately, the TEU makes no clear indication that member states

\footnotetext{
${ }^{119}$ EUROPOL's History, EUROPOL's website. Accessed on 4 November 2014. https://www.europol.europa.eu/content/page/history-149

${ }^{120}$ Treaty of the European Union 2008, Article 42(1).
} 
are required or recommended to supply these EU organs with intelligence data. Consequently, this means that the PSC cannot properly and effectively monitor the international system or attempt to control any security threats unless member states comply and decide to contribute some intelligence analysis to the EUMS. This continues to demonstrate how the EU keeps making small efforts in intelligence cooperation, but it is never enough and not nearly as cohesive or effective as it should be. ${ }^{121}$

Another formal institution established to promote European intelligence is the EU Joint Situation Centre/Intelligence Analysis Centre (SITCEN/INTCEN), which acts as the crisis response centre in Europe (similar to the US's Situation Room). The original name was SITCEN and it was created out of the CSDP in 1999 through a unilateral decision by the HR/VP at the time, Javier Solana. This meant that unlike Europol, SITCEN had no legal mandate within the EU. It did not even consist of all EU member states when it was first created - it was only made up of France, Germany, Italy, the Netherlands, Spain, Sweden and the UK. SITCEN's purpose was for its contributors to share sensitive intelligence information on foreign threats through OSINT. The mandate for SITCEN was increased to include external and internal threats to the EU, following the 2006 terrorist attacks in London and Madrid. The Lisbon Treaty resulted in a name change for SITCEN and a change in delegation. It was renamed to the EU Intelligence Analysis Centre (INTCEN) in January 2011 and it became a part of the newly formed EEAS. Being part of the EEAS allowed for INTCEN to receive better funding and legal status within the EU to justify its services. The primary role of INTCEN remains as the single-entry point for classified information coming from the member states' civilian intelligence and security

\footnotetext{
${ }^{121}$ The Council of the European Union, "Council Decision of 22 January 2001 Setting up the Political and Security Committee (2007/78/CFSP)," Official Journal of the European Communities, 27:1 (2001). Accessed on 7 November 2014. http://eurlex.europa.eu/legal-content/EN/TXT/PDF/?uri=CELEX:32001D0078\&from=EN
} 
services. $^{122}$ INTCEN has allowed for increased OSINT and image collection and analysis (imagery intelligence - IMINT) cooperation within Europe since 2011, but to truly have an effective intelligence approach, Europe will need to enhance its cooperation when it comes to signals intelligence (SIGINT) and human intelligence (HUMINT). ${ }^{123}$

Europeanization of Intelligence in the Future

Europol is the most harmonized polity that the EU has at the moment when it comes to intelligence sharing, because it has actually been included within the Treaty of the European Union (TEU). Article 88 of the TEU outlines Europol's legal mandate; however, this article is still only listed as part of police cooperation, rather than in Chapter II outlining the EU's CFSP and CSDP. ${ }^{124}$ While INTCEN coincides with the EEAS and has had its legal status increased, it still does not have any formal mandate when it comes to intelligence gathering. It obtains its information from member states willing to cooperate (e.g. France, Italy and Germany will sometimes use their satellites to contribute to IMINT for INTCEN), and the only way INTCEN can acquire information on its own is through OSINT. Their chief mandate is to provide intelligence analysis and strategic assessments to EU decision-makers, especially when it comes to counter-terrorism. ${ }^{125}$ This contributes to the ineffective pattern that appears in all of these European intelligence mechanisms: they primarily address strategic issues and there has been

\footnotetext{
${ }^{122}$ Mai'a K. Davis Cross, "A European Transgovernmental Intelligence Network and the Role of IntCen," Perspectives on European Politics and Society 14 (2013): 392-395. Accessed on 3 November 2014. DOI: 10.1080/15705854.2013.817805

${ }^{123}$ John M. Nomikos, "European Union Intelligence Agency: A Necessary Institution for a Common Intelligence Policy?" In Contemporary Issues and Debates in EU Policy: The European Union and International Relations, ed. Vassiliki N. Koutrakou. (Manchester: Manchester University Press, 2004), 46.

${ }^{124}$ Treaty of the European Union 2008, Article 88.

${ }^{125}$ Nomikos, "European Union Intelligence Agency," 393.
} 
little improvement at the operational and tactical levels. ${ }^{126}$ Acknowledging and developing the lack of coordination amongst these intelligence agencies will enable the EU to actually institute a common and centralized approach to intelligence that has a formal mandate. With that established and contributing to the progress of the CFSP and CSDP, the EU will be able to witness significant development in the area of political integration.

Although the EU may be falling short of a common intelligence policy, let alone an institution, it is shown that intelligence cooperation can be possible because of the various institutions that have already been established. These existing institutions serve as a baseline from which the EU could further develop a common approach and address existing issues in European intelligence cooperation. However, the EU has created anarchic intelligence-sharing institutions up until now. There are technical mechanisms to facilitate voluntary information sharing, but nothing has been established to encroach on a state's autonomy to decide whether or not to share intelligence. ${ }^{127}$ Without a cohesive, common policy and approach to intelligence in Europe, none of the member states are willing to co-operate on a voluntary basis. It may seem as though intelligence sharing would be in the interest of the member states, but there's the principle of control in intelligence: the service who first obtains the intelligence has the right to control how it is used, who else it can be shared with, and what action can be taken on it. ${ }^{128}$ This principle is the essence of intelligence because it highlights the importance and power of information because intelligence services do not want to risk compromising their sources.

\footnotetext{
${ }^{126}$ Martin Norheim-Martinsen and Jacob Aasland Ravndal, "Towards Intelligence-Driven Peace Operations? The Evolution of UN and EU Intelligence Structures," International Peacekeeping 18:4 (2011), 464. Accessed on 2 November 2014. DOI:10.1080/13533312.2011.588391

${ }^{127}$ James Igoe Walsh, "Security Policy and Intelligence Cooperation in the European Union," paper prepared for the biennial meeting of the European Union, April 2009, 2. Accessed on 27 October 2014. http://www.euce.org/eusa2009/papers/walsh_12C.pdf

${ }^{128}$ John Sawers, former MI6 Chief, "Sir John Sawers's speech - full text,” The Guardian, 28 October 2010, https://www.theguardian.com/uk/2010/oct/28/sir-john-sawers-speech-full-text.
} 
Competing intelligence agencies within the same country have trouble sharing intelligence with one another, let alone agencies from different countries. ${ }^{129}$

The absence of a common intelligence policy reinforces mistrust between states because there is no guarantee to prevent defection or withholding information from one another. Ad hoc forums and bilateral agreements that have been the basis of EU intelligence cooperation since the 1970s must be replaced with an institution that will work to gather and analyze relevant information, not only through OSINT, but also utilizing IMINT, HUMINT and SIGINT.

Furthermore, states must come to terms that intelligence sharing is changing with the current state of international security, where many security issues transcend geopolitical boundaries. This has been especially prevalent with the threat of terrorism in the EU, where evidence was shown that Daesh external operators in one European city have often freely travelled between other European cities without being stopped by local law enforcement or border agencies. By joining the EU, member states are already part of an extremely federated organization (without being an actual federation) that has cooperation embedded as a value. They must be willing to give up some national sovereignty in order to benefit from a common, European approach, which combines resources and will promote efficiency to ensure security across Europe. Partial intelligence cooperation is evident in Europe as institutions are already in place; what is needed is a formal mandate, and a common intelligence policy and agency, that will propel Europe forward and allow them to reach further political integration that will benefit the security of all of the member states.

\footnotetext{
${ }^{129}$ Robin Simcox, “Europe, Stop Trying to Make ‘Intelligence Sharing' Happen,” Foreign Policy, 14 April 2016, http://foreignpolicy.com/2016/04/14/europe-stop-trying-to-mak-brussels-paris-bombings/.
} 
One of the primary purposes of this thesis was to conduct a qualitative policy analysis examining the effectiveness of the EU's counterterrorism measures, hypothesizing that there is a severe lack in preventative measures despite the EU's apparent commitment via the PREVENT pillar of the EU's Counterterrorism Strategy (2005).

The EU Counterterrorism Strategy (2005) was also analyzed because of its strategic oversight and direction of measures enacted and implemented following its introduction. The remainder of this subsection will first provide a critical evaluation of the EU's Counterterrorism Strategy, then it will outline the macro findings of the analysis conducted on the 139 measures.

\section{EU Counterterrorism Strategy (2005)}

The EU's Counterterrorism Strategy was introduced in 2005 with a strategic commitment to "combat terrorism globally while respecting human rights, and make Europe safer, allowing its citizens to live in an area of freedom, security and justice." ${ }^{130}$ The document presents a highlevel list of priorities for the EU which are organized into four overarching pillars: PREVENT, PROTECT, PURSUE, and RESPOND. The pillars themselves are an adequate representation of the process of counterterrorism, but the policy analysis following the Strategy's overview reflects the disproportionate number of measures that fall under the PROTECT and PURSUE pillars (despite that the PREVENT pillar is described as a "central element of the EU's common counterterrorism policy"131). The following evaluation will first provide an overview of the

\footnotetext{
${ }^{130}$ European Union. 2005. Council of the European Union. European Union Counterterrorism Strategy, Council Document 14781/1/05, The Strategy was revised in November 2008. Council Document 15175/08. Page 3. http://register.consilium.europa.eu/doc/srv?l=EN\&f=ST\%2015893\%202010\%20REV\%201

${ }^{131}$ Ibid.
} 
Strategy prior to identifying the problems of existing provisions and the missing gaps for effective results.

The four pillars of the Strategy follow an operational order for combatting terrorism, depending on the stages of the adversary's activities. The document outlines each of the pillars' objectives, which can be seen in Figure 4.4:

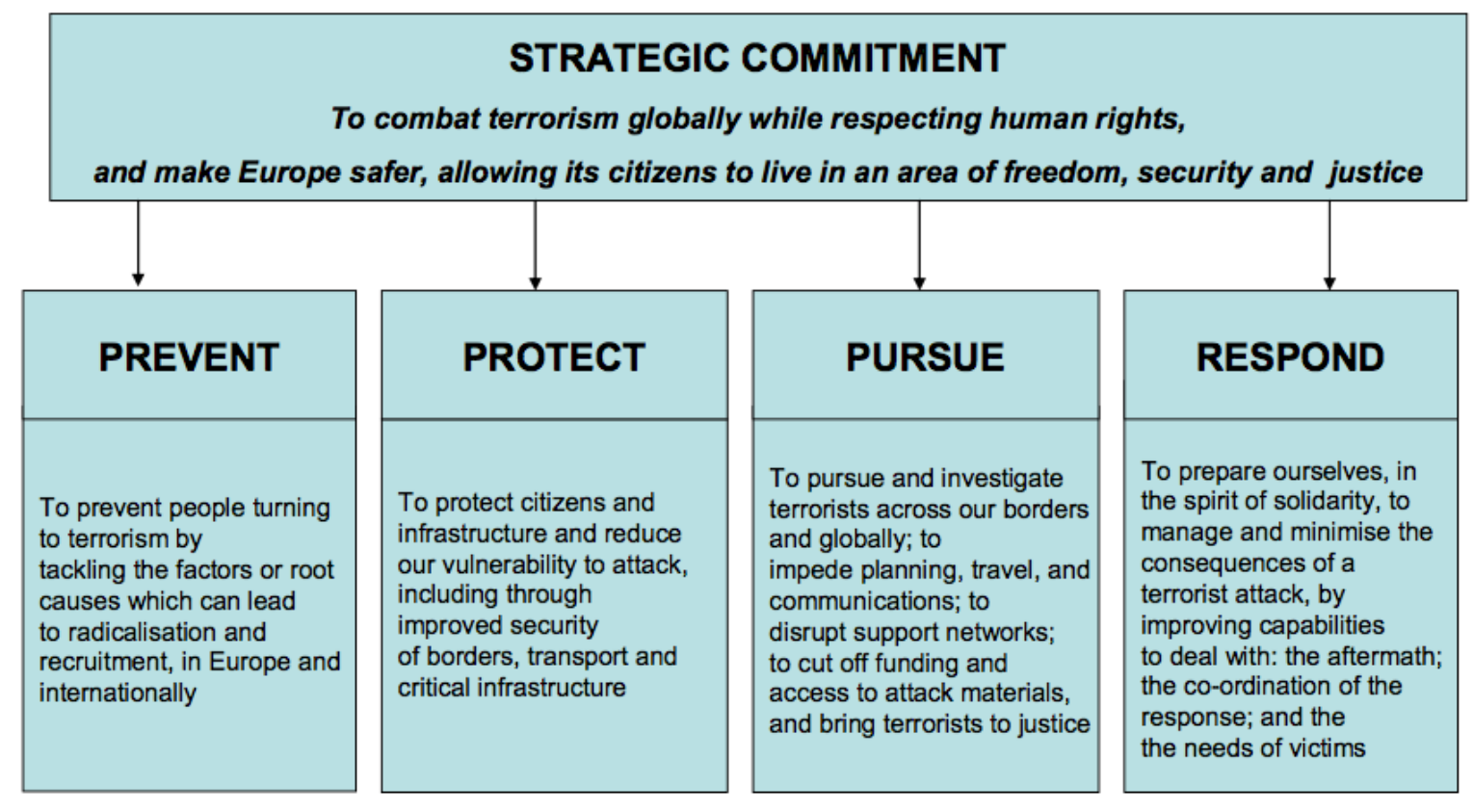

Figure 4.4 Pillars of the EU Counterterrorism Strategy (2005). Source: the EU Counterterrorism Strategy 2005 official

The Strategy itself, which was entered into force in 2005 but has not been revised since 2008, was followed by a periodically amended EU Action Plan on Combatting Terrorism. The Strategy's priorities were reflected in this Action Plan, as it is based off the four pillars, and it highlights what member states have done thus far and what (general) aims the EU wishes to achieve. The strategic commitment is broad and universal enough that it does not require a thorough update, but the discourse within the strategy does not encompass an understanding of terrorism beyond the general idea that they are "bad guys" whose operations need to be disrupted 
and members/affiliates of organizations must be caught. The larger issue of approaching terrorism from a broad viewpoint is that it lumps all of the extremist ideologies together, without addressing different motives for radicalization and participation in terrorist groups and activities. This is a problem that is not limited to the EU because it represents the way policies are written and pushed by politicians who are constituent representatives and not necessarily experts in terrorism studies, let alone counterterrorism officials. As a result, terrorism is viewed in a very narrow-minded way that fails to acknowledge many contributing factors that can be addressed in order to prevent terrorist sympathizers, recruitment, and attacks.

The insularity of the Strategy's discourse on terrorism is revealed in several ways. First, there is an inexplicit targeting of jihadist extremism without directly referencing the ideology. The Strategy declares that it focuses on countering radicalization and recruitment for "groups such as Al Qaeda and the groups it inspires, given that this type of terrorism currently represents the main threat to the Union as a whole". ${ }^{132}$ The severity of the threat posed by "groups such as Al Qaeda" cannot be denied, but centering an entire counterterrorism strategy on one ideology (that accounts for a fraction of the persistent violent threats posed by extremists in the EU) ignores the security gaps that then exist because resources are diverted from other "types" of terrorism. Europol's 2017 TE-SAT finds that a large majority of failed, foiled, or completed attacks in 2016 were attributed to left-wing and ethno-nationalist/separatist terrorist groups ${ }^{133}$; these finds are relatively consistent with previous TE-SATs as well. The highest number of casualties and fatalities are attributed to jihadist extremists in the 2016 and 2017 report because of the surge in attacks inspired or orchestrated by Daesh throughout 2015 and 2016 . However, this was not the case for nearly a decade while the Strategy was in place; this is not necessarily a

\footnotetext{
${ }^{132}$ European Union Counterterrorism Strategy, 2005, 8.

${ }^{133} 2017$ Terrorism Situation and Trend Report. Europol. https://www.europol.europa.eu/activities-services/main-reports/euterrorism-situation-and-trend-report
} 
representation of the effectiveness of the Strategy. The surge in jihadist extremism and its acute threat can be attributed to other possible factors, such as the extensive use of social media amongst jihadist networks in the last few years, the rise of Daesh's Caliphate and their instructions for supporters and affiliates to conduct attacks in their home countries using any means necessary. If the Strategy wishes to focus on jihadist extremism (and more specifically Salafi/Sunni jihadism), then it should address the ideology and the various motives of the groups and individuals.

This leads to the second way that the Strategy's discourse is problematic and insular: it fails to acknowledge the accurate objective of terrorism. The Strategy opens by declaring that terrorism is a threat to European security and the values of democratic societies by the indiscriminate targeting of innocent people, which is a vague and self-victimizing description of the terrorists' objectives. Innocent people have suffered in the aftermath of terroristic plots, but counterterrorism policies continuously fail to directly address that terrorism is a form of communication and the goal is to disrupt the political process of a country because terrorist organizations are vehemently opposed to specific domestic or foreign policies. ${ }^{134}$ Terrorist organizations are often extremely clear in their motivations and objectives, and as it was stated in the literature review of this thesis, terrorists are rational actors. They do not view themselves as the "bad guys" - after all, there is a reason that the saying is "one man's terrorist is another man's freedom fighter". Defining who is the "terrorist" is extremely subjective descriptor that depends upon who is the definer. ${ }^{135}$ Moreover, by providing us with their detailed objectives and motivations, many which hardly change throughout the years (changes that terrorist

\footnotetext{
${ }^{134}$ Freedman, Lawrence Z. 1983. "Why Does Terrorism Terrorize?" Terrorism, 6(3), 389-401. ; Louise Richardson. 2007. What Terrorists Want: Understanding the Enemy, Containing the Threat. Random House Publishing

${ }^{135}$ Boaz Ganor (2002) Defining Terrorism: Is One Man's Terrorist another Man's Freedom Fighter?, Police Practice and Research, 3:4, 287-304, DOI: 10.1080/1561426022000032060
} 
organizations do make are often to their hierarchal structures and modus operandi), thereby providing affected governments, such as the EU and its member states, a clear idea of what has to be done to tackle terrorist organizations as a whole.

Not surprisingly, the Strategy is written from a highly politicized perspective (as all policy is) that automatically positions and conceptualizes terrorists as "bad guys all the time". The actions carried out by some groups and individuals are no doubt horrific, but by dehumanizing the individuals and refusing to acknowledge the reasons people turn to terrorism, governments are doing themselves a disservice and just promoting ineffective policy that wastes resources. This is not to say that governments should concede to the demands of terrorists in order to produce effective counterterrorism measures. Rather, strategies such as the EU's Counterterrorism Strategy, must reflect an understanding of terrorism from a foundational level that includes acknowledging that variety of ideologies and motives driving groups, and most importantly, acknowledge the domestic/European policies that elicit anger from terrorist organizations, even if that anger derives from a subjective or narrow outlook on the issue. This is an uncomfortable task for European governments to accomplish because it requires recognizing that terrorists are rational actors, and moreover, acknowledging their humanity. Doing so will allow for the development of effective rehabilitative measures for those who are already radicalized and have a chance and/or desire for societal reintegration, while also enabling the development of preventative measures that tackles the root of the problem.

The Strategy highlights several times, particularly under the PROTECT pillar, that the external borders must be protected and that the threat is derived from outside Europe. On the one hand, this is true to a certain extent (particularly with the rise and fall of Daesh's Caliphate, terrorist training camps taking place in conflict zones not controlled by local governments, and 
organized criminal groups outside of Europe that collaborate with terrorist organizations), but the Strategy completely externalizes the problem by failing to address the domestic terrorist threat, particularly as a result of homegrown terrorists. In the introduction of the Strategy, it states that the assisting "priority" third countries (namely those in North Africa, the Middle East, and South-East Asia) is vital, and that working to resolve conflicts will be "essential" to the Strategy. The PURSUE pillar also reiterates this commitment to global dimension of the Strategy. Given the EU's limited competencies in the field of foreign, security, and defence policy, particularly back in 2005 when the Strategy was first invoked, this is an overreaching goal for the Union. Although the EU has partaken in a variety of military and civilian missions and operations through the CSDP, the Union has been limited by resources and powers that essentially restricted them to peacekeeping and peacebuilding capacity. These are important roles to play, given that one of the primary critiques of the United States' war against Al Qaeda was that their military never remained in a region long enough to provide peacebuilding and regional development assistance to ensure that terrorist organizations cannot exploit poor security conditions. ${ }^{136}$ Given that the EU is looking to expand its external competencies with the development of a joint military, this would be a role that the EU could build on to ensure long-term stability in regions outside of Europe.

In several provisions within the PURSUE pillar, the Strategy highlights encouraging intelligence and information sharing through various fora, and stresses the need for collective action and rapid sharing in the RESPOND pillar. In addition, it also outlines the commitment for police and judicial cooperation through instruments such as the Passenger Name Records (PNR), European Arrest Warrant, the Visa Information System, the Schengen Information System, and

\footnotetext{
${ }^{136}$ Julia McQuaid et al. "Independent Assessment of US Government Efforts against Al-Qaeda.” CNA Analysis \& Solutions. Published in October 2017. https://www.cna.org/can files/pdf/DRM-2017-U-015710-2Rev.pdf
} 
the Joint Situation Centre. While the initiatives and intent are valiant, it contributes to the lack of institutional harmonization and continues to develop instruments and institutions devoted to intelligence sharing that are not necessarily centralized nor mandatory. The Strategy also proves to be outdated because a more current version should take into account the massive role data sharing now has and the important role that the Internet plays for terrorist propaganda, networking, and operations. In the Strategy's Action Plan, there is no demonstrated intent of forming a centralized approach to intelligence sharing and gathering; there are commitments to continue to share information on explosives, the PNR, Financial Messaging Data, and the automated exchange of DNA fingerprint and vehicle registration data. The Action Plan also highlights changes made to Europol's legal framework and how it will affect its counterterrorism activities. Nevertheless, coordination still proves to be a difficult task, even with the commitment and pursuance of the various initiatives. ${ }^{137}$

The number of various measures, instruments, and institutions that play a role in counterterrorism and that attempt to form methods of intelligence and information sharing just supports the argument that the EU may be nothing more than a "Paper Tiger", in which the sheer number of legal instruments has made it difficult for the EU to act as a single unit when combatting terrorism. Commitments that the Strategy makes, and that the Union can actively commit to, include the multiple risk assessments and risk analyses promised by the Strategy, in addition to the number of measures geared to combat terrorism financing, and this is simply a result of the EU's competencies. While the Union's objectives are broad, the four pillars can be applauded for dividing up counterterrorism measures in a more logical way than the United States' strategy of "disrupt, dismantle, and defeat", which actually argues for three different and

\footnotetext{
${ }^{137}$ Oldrich Bures. 2006. "EU Counterterrorism Policy: A Paper Tiger?” Terrorism and Political Violence 18(1): 63.
} 
competing outcomes. ${ }^{138}$ The EU's strategic commitment in its Strategy to "combat" terrorism, which at least does not provide paradoxical objectives, could be clarified to determine whether the Union's ultimate goals are to disrupt terrorist networks, dismantle terrorist organizations and their affiliates, or completely defeat the threat of terrorism. However, "defeating terrorism" was acknowledged as ineffective by the Israeli counterterrorism officials, who are considered to have the most "effective" counterterrorism strategies. ${ }^{139}$

There are a number of ways that the EU can update and improve its Counterterrorism Strategy, namely by altering its understanding of terrorism, by clearly defining the Union's objectives, and by instilling harmonized responses and tactics for countering terrorism that do not require more institutions and legal instruments. The following subsection provides the evaluation that was derived from the analysis of 139 counterterrorism measures developed by the EU, 102 of which were introduced after the Strategy. Additionally, it should be noted that 88 of those measures were amendments to original legislation, meaning that only 51 measures are unique. The measures analyzed do not reflect all of the counterterrorism measures enacted or proposed by the EU, but it is meant to serve as a macro analysis of some of the terrorism-specific measures to illustrate the imbalance of the Strategy, the lack of harmonization, and the shortage of preventative and reintegrative measures.

\footnotetext{
${ }^{138}$ Julia McQuaid, et al., Independent Assessment of U.S. Government Efforts against AlQaeda, The CNA Corporation, October 2017. https://www.cna.org/cna_files/pdf/DRM-2017-U-015710-2Rev.pdf

139 Arjun Chowdhury and Scott Fitzsimmons. 2013. "Effective but inefficient: understanding the costs of counterterrorism." Critical Studies on Terrorism 6(3): 447-456 ; T.W. van Dongen. 2011. "Break it Down: An Alternative Approach to Measuring Effectiveness in Counterterrorism.” Journal of Applied Security Research 6(3): 357-371.
} 
General Trends Derived from the Policy Analysis of the EU's Counterterrorism Measures Introduced Between 2001 and 2016

Counterterrorism should not simply be examined from the number of measures produced, particularly if they are ineffective, or even inefficient. ${ }^{140}$ The qualitative policy analysis conducted for this thesis identified five themes that surfaced, which are relevant to determining why the EU's counterterrorism measures are ineffective. First, most measures are introduced after large scale attacks, rather than promoting measures based on prevention and deterrence on a consistent basis. Second, even though the EU Counterterrorism Strategy was only introduced in 2005, the large majority of measures can be categorized under the PURSUE pillar, thus further demonstrating the EU's reactionary implementation of counterterrorism measures. Third, although this study focused on formal effectiveness, it was determined that the EU lacks clear objectives in counterterrorism measures. Fourth, despite a broad range of themes that surface in counterterrorism policy making, only two primary themes surfaced in this analysis. Finally, EU counterterrorism measures fail to produce measures that can be applied across all member states that take into account the different types of attacks and targets pursued by terrorists. These five trends will be examined in detail below.

Politics of Fear

The first trend that was immediately identified was the timing of counterterrorism measures, specifically concluding that many measures were introduced and adopted following a

\footnotetext{
${ }^{140}$ Counterrorism is likely to be effective because (1) in relation to the states they attempt to coerce, terrorists tend to be materially weak actors in terms of their size and resources. The very fact that terrorist groups tend to target civilians in their attacks is a signal of their material weakness; and (2) terrorist groups face stark trade-offs between adopting organisational characteristics that should enhance either their capacity to carry out attacks or their ability to survive over the long term in the face of state efforts to eliminate them. However inefficiency can propel measures toward ineffectiveness. Counterterrorism is likely to be inefficient because states frequently overreact to terrorist attacks by pursuing inefficient, lengthy and costly counterterrorist campaigns. Source: Ibid., 448-450.
} 
large-scale attack in Europe. The figures 4.5, 4.6 and 4.7 illustrate when measures at the EU level were introduced, compared to the attacks that took place in that year:

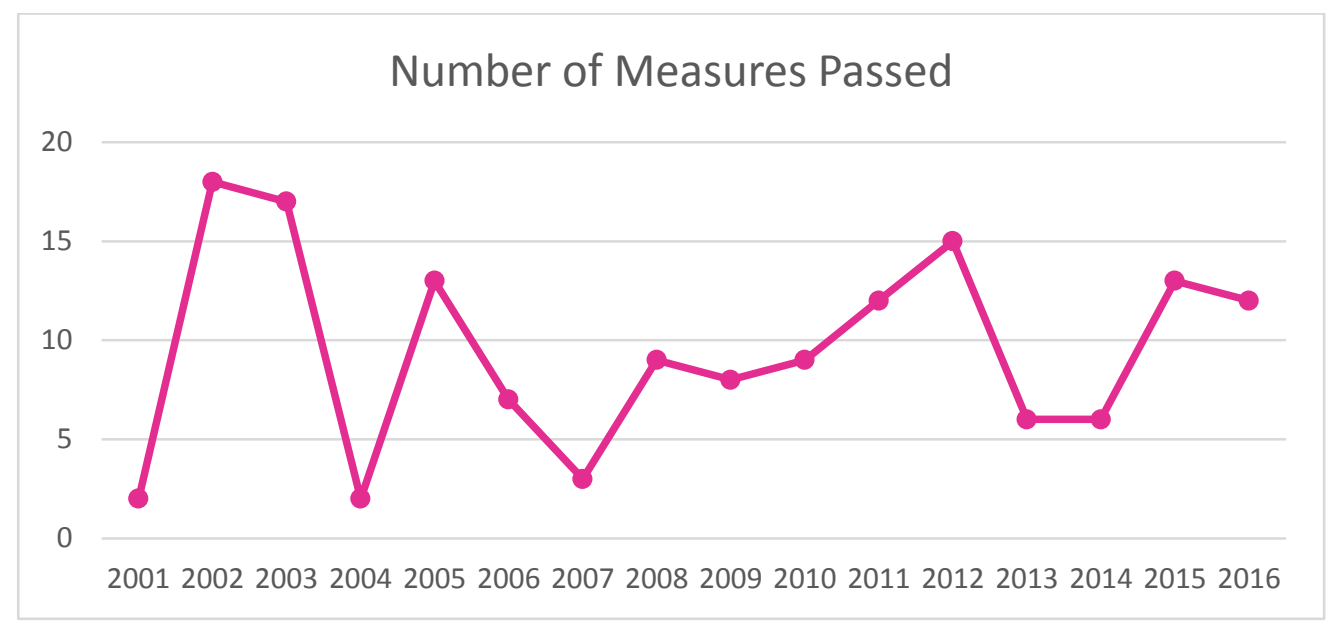

Figure 4.5 Number of Counterterrorism Measures Passed by EU Institutions Between 2001 and 2016. Chart self-produced in Microsoft Excel based on the coded documents.

Total Attacks EU 2001-2015

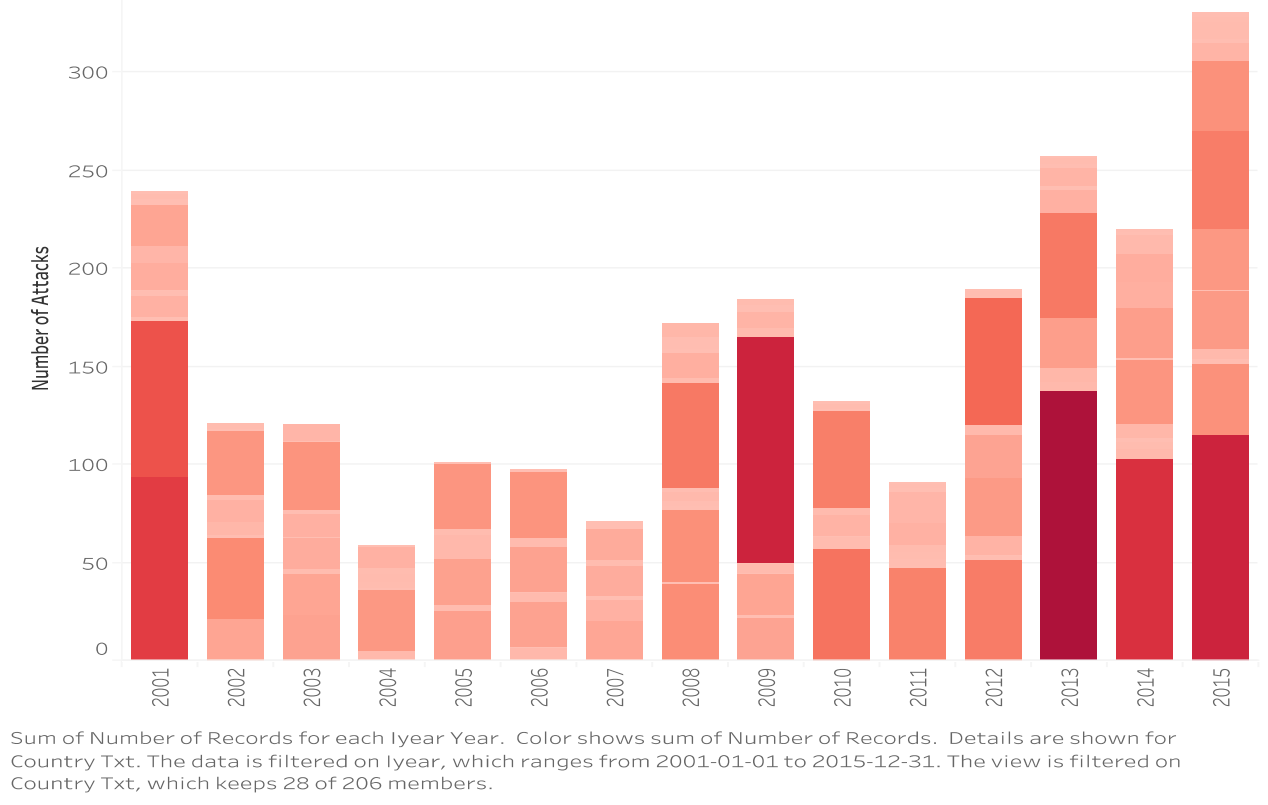

Figure 4.6 Total number of terrorist attacks in the EU between 2001 and 2015. This includes all forms of terrorism and is not limited to jihadist extremism. Data from the Global Terrorism Database self-produced in Tableau. The colours in this graph and in 4.7 reflect the number of events in each EU member state. 
250

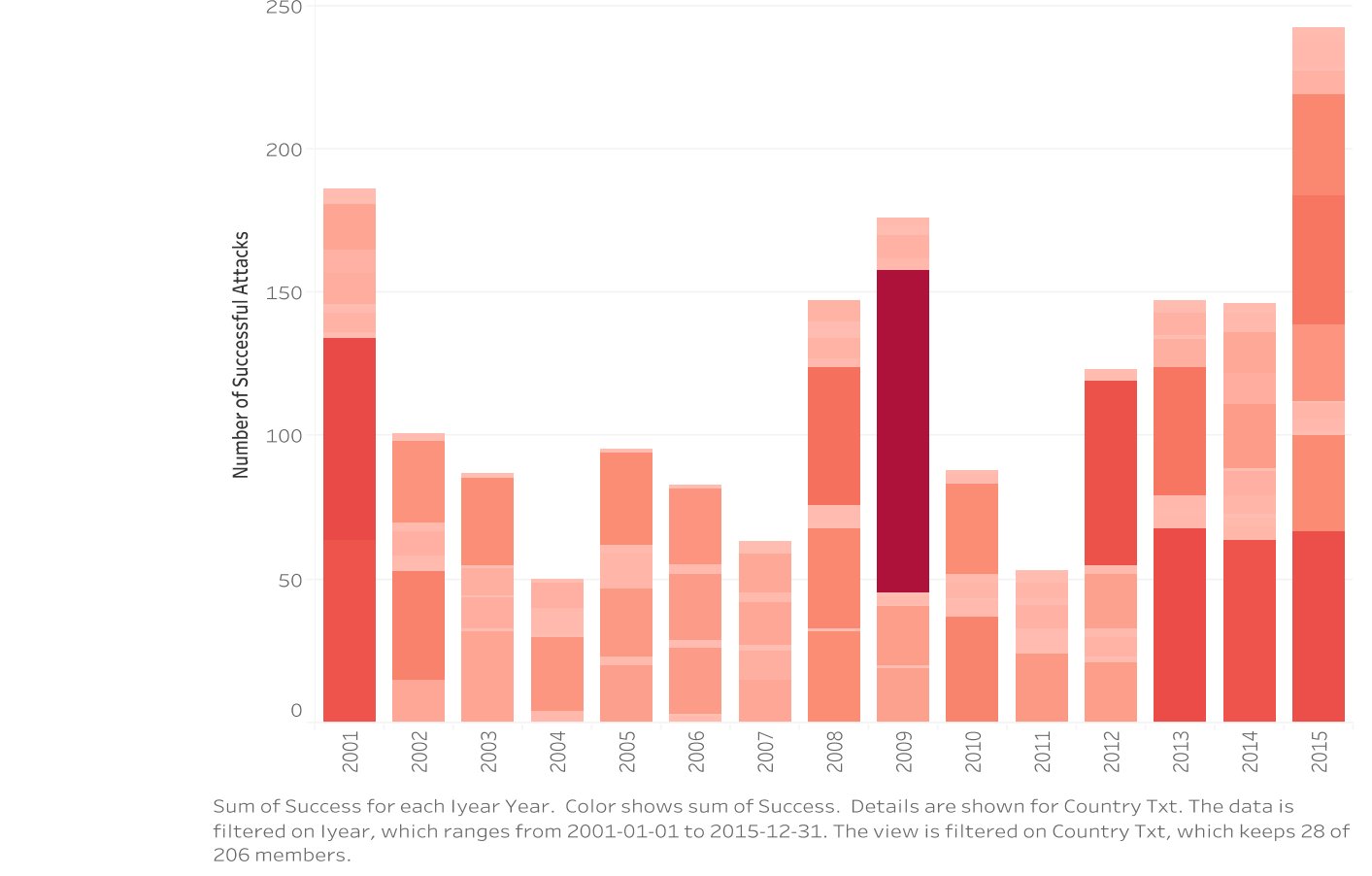

Figure 4.7 Total number of successful terrorist attacks in the EU between 2001 and 2015. This includes all forms of terrorism and is not limited to jihadist extremism. Data from the Global Terrorism Database self-produced in Tableau.

Figure 4.5 reflects approximately four surges of policy development for the EU: 20022003, 2005, 2012, and 2015. Figures 4.6 and 4.7 illustrate the total number of attacks (including failed and foiled plots) and the total number of successful attacks. Both figures take into account all motivations for terrorism, and the data comprising these graphs shows that not all attacks resulted in casualties or injured individuals, as many attacks were attacks on businesses, government buildings, and infrastructure.

The surges in policy development accurately reflect the major attacks that took place around those periods. The first surge of counterterrorism measures introduced and adopted occurred in 2002-2003, following the 9/11 attacks in the United States, but Figure 4.7 also illustrates that there were nearly 200 successful attacks that took place in the EU in 2001 as well 
(however, 64 of those attacks were attributed to attacks in the United Kingdom by paramilitary loyalist groups from Northern Ireland, and 70 attacks took place in Spain, many attributed to ethno-nationalist separatists). The second surge in 2005 began to occur following the 7/7 London bombings in 2005. The United Kingdom held Presidency for the second half of 2005, likely a reason why many measures were adopted soon after the London attacks. This also included the introduction of the EU Counterterrorism Strategy in December. The third surge in 2012 resulted in numerous amendments to various legislative acts on specific restrictive measures against persons, groups, and/or entities in order to combat terrorism. ${ }^{141}$ The speculation here is that following the death of Al Qaeda leader Usama Bin Laden a.k.a. Osama Bin Laden (UBL) in May 2011, there was likely a surge to amend existing sanctions and restrictions on Al-Qaeda members in connection to UBL and Al-Qaeda. The fourth surge in policy development took place in 2015 (and continued into 2016), following the declaration of Daesh's Caliphate and the surge in attacks inspired by Daesh across Europe, notably the January and November 2005 attacks in Paris.

By implementing numerous measures following large-scale attacks, the EU feeds into the securitization $^{142}$ of the terrorist threat, and particularly the threat derived from jihadist extremism. Attacks occur frequently throughout Europe, many initiated by ethno-nationalist separatist groups classified as terrorist organizations. Large-scale attacks may force governments and organizations to review their legislation and strategies, which proved to be beneficial following 9/11 because many countries had not made major amendments or introduced new

\footnotetext{
${ }^{141}$ Measures including, and related to: Decision 2011/872/CFSP updating the list of persons, groups and entities subject to Articles 2, 3 and 4 of Common Position 2001/931/CFSP on the application of specific measures to combat terrorism; and Implementing Regulation (EU) No 1375/2011 implementing Article 2(3) of Regulation (EC) No 2580/2001 on specific restrictive measures directed against certain persons and entities with a view to combating terrorism

142 "Securitization" is the process of state actors transforming subjects into matters of "security". It is an extreme version of politicization that enables extraordinary means to be used in the name of security. Issues that become securitized do not necessarily represent issues that are essential to the objective survival of a state, but rather represent issues where someone was successful in constructing an issue into an existential problem. Source: Barry Buzan, Ole Wæver, and Jaap de Wilde, Security: $A$ New Framework for Analysis, Boulder: Lynne Rienner Publishers, 1998, 25.
} 
measures since the 1980s. However, the EU's counterterrorism measures come across as purely reactionary rather than preventative. Measures cannot be concluded to be effective because of the surge in attacks in the last few years, and throughout the 2000s. The EU adopts and implements policies that are only useful for the aftermath of terrorist attacks, such as measures targeting known terrorist affiliates and strengthening the security of borders and critical infrastructure. By only reacting to terrorist attacks and only taking action a fraction of the time to implement preventative measures, the EU does not produce effective or efficient results for combatting terrorism.

\section{Skewed Pillars of the Counterterrorism Strategy}

The policy analysis examined the number of measures that would fit under each of the Strategy's pillars, which are PREVENT, PROTECT, PURSUE, and RESPOND. Due to the qualitative nature of this analysis, categorizing measures under the four pillars likely resulted in subjective decisions; however, the Strategy outlines the various measures which would fall under each pillar, therefore this analysis tried to follow those provisions as closely as possible. Figure 4.8 depicts the number of analyzed measures that fall under each pillar: 


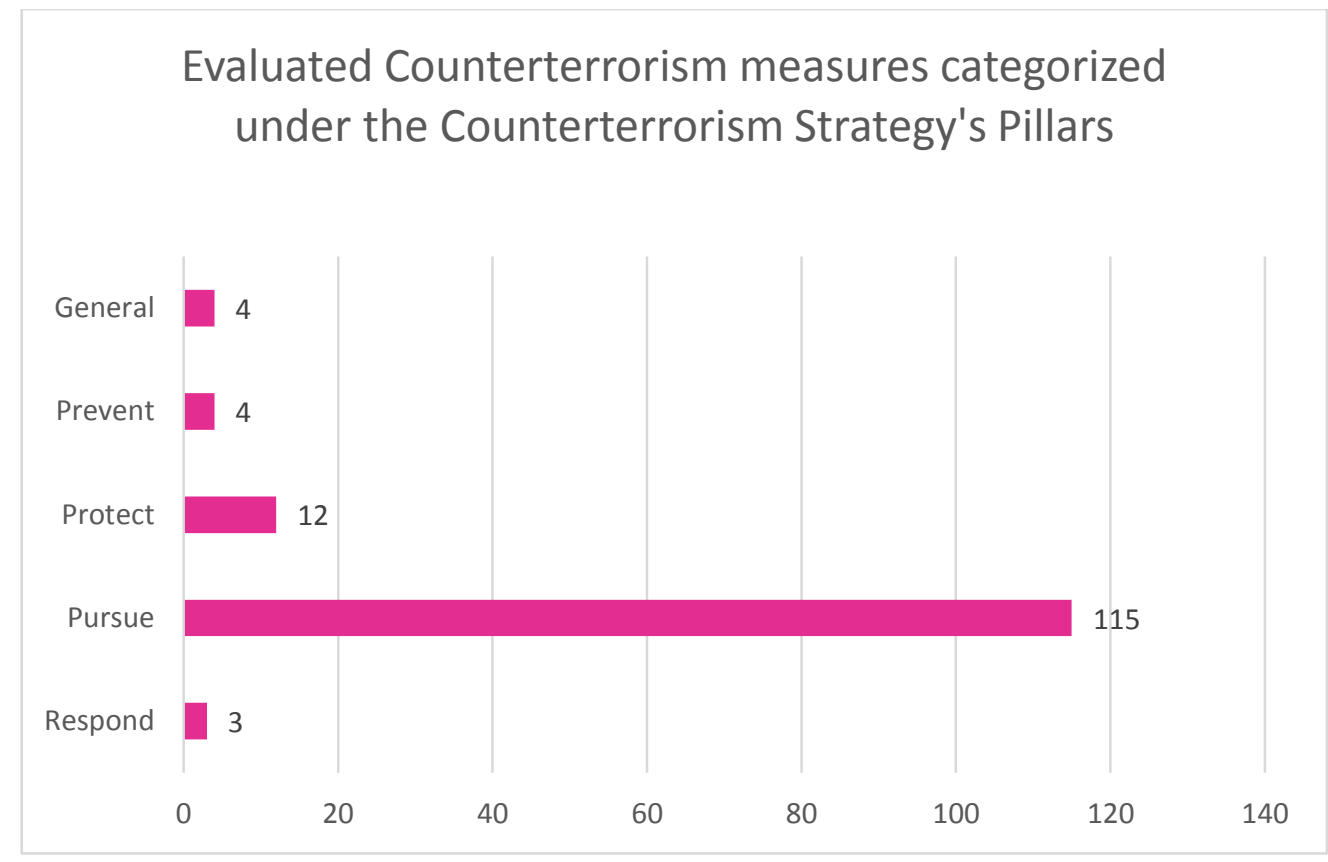

Figure 4.8 Evaluated counterterrorism measures categorized under the EU Counterterrorism Strategy's Pillars. Chart selfproduced in Microsoft Excel based on the coded documents.

The vast majority of measures $(82.7 \%)$ fall under the PURSUE pillar, which includes amendments made to Decision 2011/872/CFSP updating the list of persons, groups and entities subject to Articles 2, 3 and 4 of Common Position 2001/931/CFSP on the application of specific measures to combat terrorism and Implementing Regulation (EU) No 1375/2011 implementing Article 2(3) of Regulation (EC) No 2580/2001 on specific restrictive measures directed against certain persons and entities with a view to combating terrorism. The sheer number of measures adopted under the PURSUE pillar exemplifies the first trend examined in this analysis, namely that the EU's measures are reactionary. While they may be effective in sanctioning the activities of terrorists and their networks by cutting off their financing, this does little to prevent from further radicalization and recruitment of individuals. PURSUE measures may produce effective instruments for targeting terrorists that work in conjunction with national measures for pursuing terrorists at home and abroad, but these are temporary solutions. Without the addition of measures that address the root causes of terrorism, particularly those that are related to socio- 
economic reasons, the EU is not producing effective measures for combatting terrorism in the long-term. It is far more expensive to allocate resources toward increasing internal and external security architectures (for the purpose of targeting and attempting to defeat terrorist organizations) compared to allocating resources toward grassroots organizations and communities to ensure that individuals susceptible to radicalization are integrated into a society and community that does not advocate for extremist ideologies.

Out of the four preventative measures analyzed that were adopted by the EU between 2001 and 2016, three of them were initiated in 2015 (out of 13 overall measures introduced in 2015), indicating a small shift in perception about how counterterrorism should develop. The one preventative measure introduced before 2015 was the Council Decision of 12 February 2007 establishing for the period 2007 to 2013, as part of General Programme on Security and Safeguarding Liberties, the Specific Programme Prevention, Preparedness and Consequence Management of Terrorism and other Security related risks. The general aim of this Decision was to prevent terrorists from accessing materials (particularly chemical, biological, radiological, and nuclear [CBRN] material) that would enable them to conduct attacks. This measure may be categorized as a PREVENT measure, but it does nothing to address how to prevent individuals from supporting and joining terrorist organizations.

The three 2015 measures introduced include one Directive aiming to prevent the use of financial systems for the purposes of terrorist financing (thereby reducing it to the same type of preventative strategy as the aforementioned Decision on CBRN material), and a Council Decision establishing a convention on the preventing of terrorism, in addition to a protocol for this Decision. However, this Decision and its Protocol are not EU initiative; in the Protocol's introduction, it is stated that its aim is to facilitate the "implementation of UN Security Council 
Resolution 2178(2014) on foreign terrorist fighters and, in particular, at establishing criminal offences for certain acts identified in operative paragraph 6 of that Resolution". ${ }^{143}$ The Protocol itself also acknowledges the importance of understanding foreign fighter related offences and how they compare to criminal offences of a preparatory nature with the possibility of leading to terrorist acts, because this basic understanding is crucial to developing effective criminal justice instruments for combatting terrorism. For the most part, the UN resolution referred to in the Protocol provides standard provisions calling upon greater cooperation amongst states for countering the terrorist threat posed by groups such as Al Qaeda, Daesh, and their affiliates, along with provisions on continuing sanctions, improving border security, and improvements to counterterrorism monitoring instruments. One section is devoted to countering violent extremism (CVE), and while most of the provisions do not necessarily call upon revolutionary actions to prevent terrorism, there are two articles that should be highlighted:

16. Encourages Member States to engage relevant local communities and nongovernmental actors in developing strategies to counter the violent extremist narrative that can incite terrorist acts, address the conditions conducive to the spread of violent extremism, which can be conducive to terrorism, including by empowering youth, families, women, religious, cultural and education leaders, and all other concerned groups of civil society and adopt tailored approaches to countering recruitment to this kind of violent extremism and promoting social inclusion and cohesion; and,

19. Emphasizes in this regard the importance of Member States' efforts to develop nonviolent alternative avenues for conflict prevention and resolution by affected individuals

\footnotetext{
${ }^{143}$ Council Decision (EU) 2015/1914 of 18 September 2015 on the signing, on behalf of the European Union, of the Additional Protocol to the Council of Europe Convention on the Prevention of Terrorism (CETS No 196)
} 
and local communities to decrease the risk of radicalization to terrorism, and of efforts to promote peaceful alternatives to violent narratives espoused by foreign terrorist fighters, and underscores the role education can play in countering terrorist narratives. ${ }^{144}$

These two provisions provide potential for the EU to move forward with creating more holistic approaches to counterterrorism that take the affected individuals into account as rational actors, and by implementing community-oriented policies along with deterrent policies that replicate the Italian efforts in the late 1980s to reintegrate extremists into society (this will be expanded on in the following chapter on the Italian case study). This Resolution (along with the Decision and Protocol) likely led to the non-binding November 2015 resolution by the European Parliament on preventing radicalism, ${ }^{145}$ and while it aims to serve as a holistic approach to counterterrorism, the Resolution does not provide any avenues for states to follow, resulting in an unbalanced strategy that enables some states to not adequately implement preventative approaches. Therefore, not only are the Union's counterterrorism measures a reactionary response to most large-scale events, but they also fail to develop adequate measures under the PREVENT pillar to ensure that the problem of extremism is actually mitigated to ensure long-term counterterrorism success. Rather, the EU's measures only provide short-term successes by preventing terrorism financing and sanctioning groups and individuals affiliated with terrorist organizations.

\section{Lack of Clearly Defined Objectives}

\footnotetext{
${ }^{144}$ United Nations Security Council Resolution 2178/2014 on Foreign Terrorist Fighters. http://www.un.org/en/sc/ctc/docs/2015/SCR\%202178 2014 EN.pdf

${ }^{145}$ European Union. 2015. Parliament Resolution of 25 November 2015 on the Prevention of Radicalization and Recruitment of European Citizens by Terrorist Organizations. http://www.europarl.europa.eu/sides/getDoc.do?pubRef=$\% 2 \mathrm{f} \% 2 \mathrm{fEP} \% 2 \mathrm{f} \% 2 \mathrm{fTEXT} \% 2 \mathrm{bTA} \% 2 \mathrm{bP} 8-\mathrm{TA}-2015-0410 \% 2 \mathrm{~b} 0 \% 2 \mathrm{bDOC} \% 2 \mathrm{bXML} \% 2 \mathrm{bV0} \% 2 \mathrm{f} \% 2 \mathrm{fIT}$
} 
The findings regarding the objectives of counterterrorism measures were consistent with Martins and Ferreira-Pereira's conclusions that effectiveness is correlated with the presence of clear counterterrorism objectives. ${ }^{146}$ According to them, in the case of the EU, they have no clear objectives stated in the existing documents, thus indicating ineffectiveness. Following the analysis of the 139 counterterrorism measures, the same can be concluded with this thesis' assessment.

However, the preliminary analysis did still produce findings that continuously suggest that the EU fails to form highly effective objectives, thus implicating the final outcomes of counterterrorism measures as there is no adequate goal to achieve beyond implementation of specific instruments and/or encouraging cooperation. None of the measures reflect all five components of the SMART model; components that were most likely to be fulfilled were "Specific" and "Relevant". The "Relevant" component was primarily easy to fulfill following large-scale attacks that required direct action under the PROTECT and/or PURSUE pillars. The "Specific" component applied to measures that introduced unique new counterterrorism instruments, which was consistently applicable to all measures introduced under the PROTECT pillar, because those tended to result in specific instruments (namely the Schengen Information System and the PNR). All measures resulted in sanctions fulfilled the "Achievable" component of the model, in addition to the measures under the PROTECT pillar. However, the vagueness of policies, in addition to the fact that many EU measures allow member states to implement the measures in any way they choose, makes it difficult to actually assess how achievable a measure really is across the different member states. None of the measures examined fulfilled components for "Measurable" or "Time-bound"; EU legal acts nearly always require a review of the

\footnotetext{
${ }^{146}$ Martins, Bruno Oliveira and Laura C. Ferreira-Pereira. "Stepping inside? CSDP missions and EU counter-terrorism." European Security 21:4 (2012): 537-556.
} 
legislation after a certain time frame and a deadline for member states implementation of EU legislation, but this does not provide member states an incentive to actually achieve successful output results based on these measures. As a result of the EU's failure to produce meaningful and concrete objectives for their counterterrorism measures, it can be concluded that the measures are ineffective.

\section{Themes of the EU's Counterterrorism Measures}

The ICCT's study on the EU's counterterrorism effectiveness produced eight different themes that reflected the adopted measures: weapons, cooperation, data exchange, financial, border, justice, prevention, and general. The study is more expansive than this thesis' analysis because it took into account measures that did not necessarily have "terrorism" in the title, thus the measure fell under the "counterterrorism umbrella", and it examined legal acts beyond Decisions, Directions, and Regulations. As a result, not all themes reflected in the ICCT study were replicated in this study. This thesis' policy analysis identified nine various themes: cooperation, borders, data sharing, general, law enforcement, penalties, prevention, financial, and justice. The graph below provides a quantified illustration of the data: 


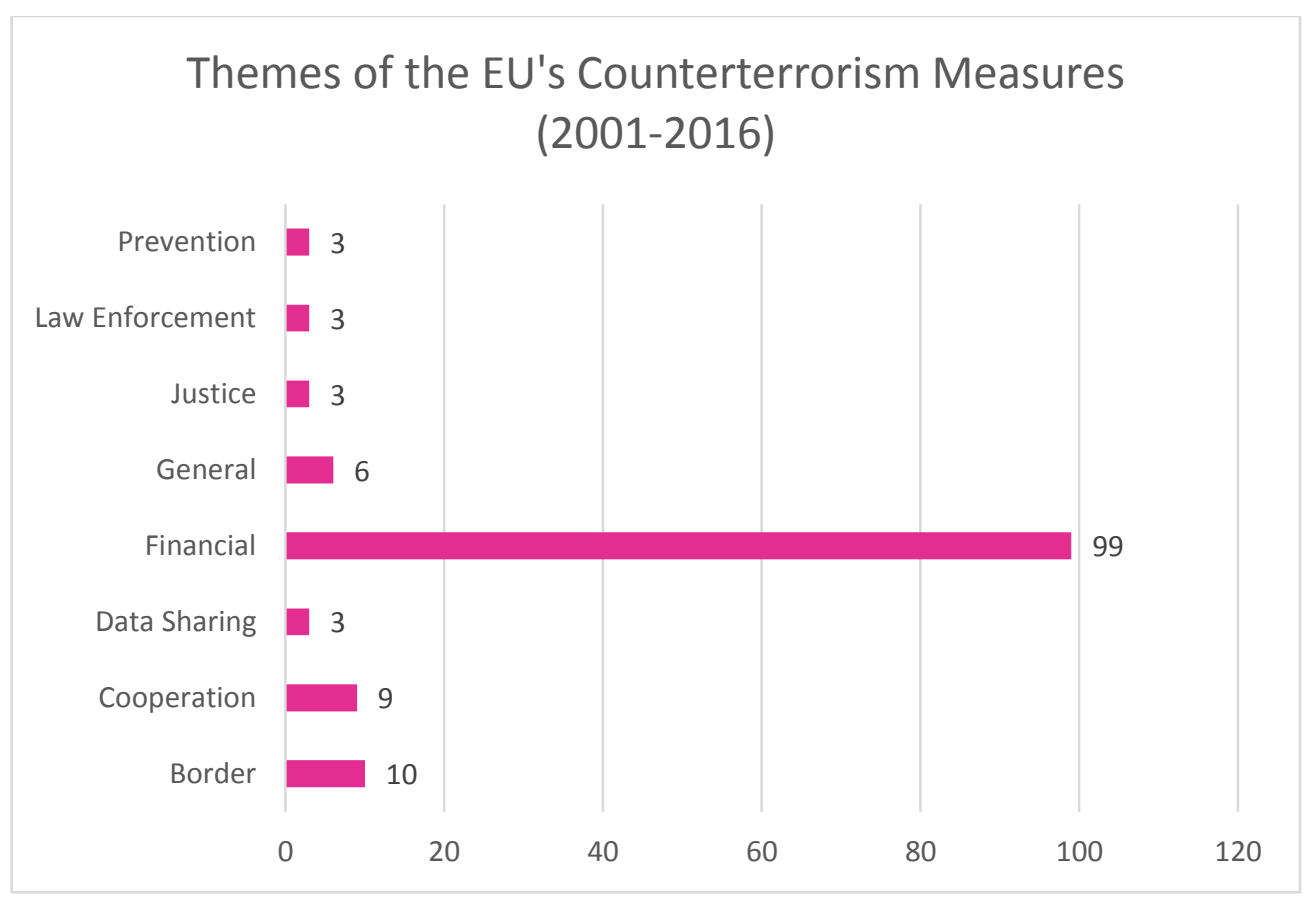

Figure 4.9 Themes of the EU's Counterterrorism Measures. Chart self-produced in Microsoft Excel based on the coded

documents

Figure 4.9 clearly demonstrates that the EU produces legislative measures in its competent policy areas, namely measures categorized under "financial", followed by "border [security]" and "cooperation". All of the measures categorized under "financial" were related to sanctions on individuals and groups affiliated with recognized terrorist organizations. Nearly $90 \%$ of these measures were amendments made under Council Regulation (EC) No 2580/2001 and Common Position 2001/931/CFSP. ${ }^{147}$ This continues to illustrate that there is a serious neglect in measures that aim to tackle the prevention of terrorism, and that the EU has not made any serious effort to implement measures that address the societal levels and socio-economic factors of radicalization and extremism.

\footnotetext{
${ }^{147}$ Council Regulation (EC) No 2580/2001 on specific restrictive measures directed against certain persons and entities with a view to combating terrorism; and Common Position 2001/931/CFSP on the application of specific measures to combat terrorism.
} 


\section{E. CONCLUSIONS}

This chapter served to provide an important background on terrorism in Europe, and how jihadist extremism manifested itself on the continent. These historical explanations are crucial to developing effective policies as it provides contextual information on the adversary; and as it was exemplified in this chapter's background section, each wave of terrorism had its main actors adopt tactics from its predecessors. This is particularly underscored by identifying how jihadist literature is influenced by the literature of late- $19^{\text {th }}$ century Russian anarchists. In The Art of War, Sun Tzu underlines the pinnacle tenant of combat by stating,

"If you know the enemy and know yourself, you need not fear the result of a hundred battles. If you know yourself but not the enemy, for every victory gained you will also suffer a defeat. If you know neither the enemy nor yourself, you will succumb in every battle. "148

Through the analysis of the EU's Counterterrorism Strategy (2005) and the binding measures adopted between 2001 and 2016, this chapter asserted this dissertation's argument that the EU's counterterrorism measures are ineffective because there is a severe lack of harmonization of policies or institutions, making it difficult to establish a unified front to combat terrorism in Europe, and that the existing measures fail to address the PREVENT pillar of the EU Counterterrorism Strategy (2005). The following section explores the Italian case study and their unique experiences with jihadist extremism combined with their historical experiences with combatting political violence in the 1970s and 1980s, and its long history with organized crime. The case study will also highlight unique measures to the Italian case and exemplify how the

\footnotetext{
${ }^{148}$ Sun Tzu, translated by Thomas Cleary, The Art of War, 1988, 53.
} 
Italian government used a strategy modeled after deterrence theory to reintegrate and prevent terrorism following the violent years in the 1970s and 1980s. 


\section{CHAPTER V: ITALY'S COUNTERTERRORISM MEASURES}

"5. The revolutionary is a dedicated man, merciless toward the State and toward the educated classes; and he can expect no mercy from them. Between him and them there exists, declared or concealed, a relentless and irreconcilable war to the death. He must accustom himself to torture." - Sergey Nechayev

\section{A. ISSUE}

The individual EU member state that this dissertation will examine as a case study is Italy. Italy provides an interesting case for comparison because of the country's battle with anarchist and left-wing terrorism in the 1970s and 1980s, resulting in some of Europe's most violent and fatal terrorist attacks at the time. Italy's case is also unique because of the prominence of organized crime in the south, and the influence anti-mafia measures have had on counterterrorism measures. Moreover, in terms of the contemporary jihadist threat across Western Europe, Italy remains unscathed despite frequent threats. The purpose of this chapter is to examine Italy's counterterrorism measures to identify where Italy differs from the EU's counterterrorism priorities, and to determine whether Italy has developed their own effective measures based on their earlier experiences with terrorism and ongoing anti-mafia operations.

\section{B. BACKGROUND ON TERRORISM AND JIHADIST EXTREMISM IN ITALY}

Between Italy's history of combatting fascist and anarchist terrorism, combined with the rise of jihadist extremism since the late 1980s and early 1990s, the Italian state is no stranger to threat posed by various violent extremist groups. Likewise, the added largescale presence of 
organized criminal groups in Italy has resulted in different trajectories and development for counterterrorism measures that do not necessarily correspond with EU trends and standards. While Italy's history with political violence and terrorism can be elaborated on in great lengths, this chapter will break down Italy's history and background on terrorism and jihadist extremism in three parts: (1) the four periods of political terrorism between 1969 and 1989 where the state had undergone a stark transition from ineffective to effective counterterrorism measures; (2) the Italian state's struggle with legitimizing its fragmented Muslim community; and (3) the characteristics and spread of jihadist extremism in Italy.

The Years of Lead: Political terrorism in Italy from 1969-1989

Anarchism has been prevalent in Italy since the late $19^{\text {th }}$ century, but the infamous Years of Lead (Italian: 'Anni di Piombo'), roughly dating from 1969 to 1989, was the renowned period for the majority of violence occurring in the 1970s. The Years of Lead were characterized by political violence perpetrated first by far-right groups before the far-left groups gained momentum and were attributed to with some of the most violent attacks during the Years of Lead. Donatella della Porta divided the Years of Lead into four periods based on significant characteristics and the evolution of Italy's counterterrorism effectiveness at this time. Della Porta's research on Italy's counterterrorism effectiveness is an interesting contribution to the literature because it predates the explosion and focus of terrorism studies, which in recent years has been dominated by a concentration on jihadist terrorism. Additionally, it is one of the few articles examining counterterrorism effectiveness that concludes with recommendations applicable to the contemporary jihadist cases. 
The first period occurred between 1969-1974, which was defined by the Italian secret service's protection of right-wing terrorist groups. Despite the attention placed on the violence perpetuated by far-left wing groups in the 1970s, the most brutal forms of political violence occurred as a result of ineffective counterterrorism measures targeting active far-right groups at the time. Italy's secret service at the time, the Servizio Informazioni Difesa (SID 1966-1974, [English: Defence Intelligence Service]), was responsible for the ineffective measures failing to identify individuals and groups responsible for the violence. ${ }^{149}$ At a time where extreme anticommunist sentiments were abounding, SID protected these extreme right-wing groups for political gain in order to induce public demand for 'law and order'. The Italian political class did not describe the violence as terrorism until 1974; they spent nearly five years using the events for short term political gains, which inevitably also contributed to the high turnover of government in Italy at this time. ${ }^{150}$ The SID itself dissolved in 1974 following the controversial protection of right-wing groups; they were replaced in 1977 by the Servizio informazioni sicurezza democratica (SISDE, English: Democratic Security Intelligence Service).

Following the immediate and evident decline of right-wing groups after 1974, the second period of the Years of Lead occurred between 1974-1976, and it was defined by the creation of anti-terrorism police units and the first defeats for left-wing terrorism. As the Red Brigades and other infamous left-wing groups rose to prominence during this period ${ }^{151}$, the Italian state counteracted including left-wing terrorism in anti-mafia measures, which resulted in new legislation on organized crime and public order that were referred to as norme di facciata

\footnotetext{
${ }^{149}$ On the Italian secret services, see G.DeLutiis, Storia dei servizi segreti (Rome:Editori Riuniti, 1984); on secret services and Italian terrorism, see L. Violante, 'Politica della sicurezza, relazioni internationali e terrorismo', in G. Pasquino (ed.), $L a$ provadelle armi (Bologna: Il Mulino, 1984).

${ }^{150}$ Donatella della Porta, "Institutional Responses to Terrorism: The Italian Case." Terrorism and Political Violence. 4:4: 153154.

${ }^{151}$ Notable groups: The Front Line, October 22 Group, the PAC, the Continuous Struggle, and the PO-AO.
} 
(English: 'façade norms') ${ }^{152}$. These so-called norms were developed, and named as such, to reassure the public about the growth of violent crime in Italy. However, the new additions of legislation did not have a direct effect on fighting terrorism, rather, two structures established in 1974 led to positive results in counterterrorism ${ }^{153}$ : the Ispettorato generale per la lotta contro il terrorismo (English: The Inspector General for the Fight Against Terrorism) and the Nucleo speciale di polizia giudiziare in Turin, Italy (English: The Special Group of Judiciary Police).

The third period of the Years of Lead shortly followed, spanning from 1977 to 1982, and it was defined by the "Emergency" policies and legislation and their outcomes. Numerous measures were introduced to tackle left-wing terrorism, but ultimately, these measures did little to efficiently combat terrorism and instead they negatively impacted civil rights. Legislation introduced during this period included more articles that specifically targeted acts of terrorism and prison reforms due to the number of prison escapes occurring. Italy officially introduced their Anti-Terrorism Law of 1980, which allowed for "preventative arrests". This meant that Italian police had the ability to preemptively detain individuals in custody upon the suspicion that they may commit a crime. While it is typical for the increase of security legislation to affect some aspects of citizens' rights, citizens expect that these measures will have effective results; this was not the case during the third period. Many of the "emergency" measures introduced were criticized because they were developed to assure the public that the state was acting against the violence, rather than actually defeating terrorism. Moreover, legislation passed during this

\footnotetext{
${ }^{152}$ New legislation included: the Provedimenti urgenti sulla giustizia penale (English: 'Urgent measures on criminal law', Decree of 11 April 1974 n.99), established to increase the maximum number of years an individual can spend in preventative detention; the Nuove norme contro la criminalità (English: 'New Regulations Against Criminality', Law of 7 June 1974, n. 220), which increased the sentencing for armed robbery, extortion, and kidnapping, which was founded after the April 1974 kidnapping and ransoming of Judge Mario Sossi by the Red Brigades; and various of smaller pieces of legislation that limited the ability to obtain bail, allowing law enforcement to conduct search and arrests without obtaining a warrant, allowing suspects to be held by law enforcement for 48 hours without charges, and preferential treatment for crimes committed by the police.

${ }^{153}$ The new structures led to the dissolution of one of the prominent left-wing groups in Italy at the time, the Armed Proletarian Nuclei, and it led to the arrest of several prominent individuals within the Red Brigade's leadership, which included Renato Curcio and Alberto Franceschini.
} 
period failed to understand terrorism as a political phenomenon and terrorist groups were treated akin to organized criminals.

Finally, the fourth period occurred between 1982-1989, and it was defined by the new anti-terror policies and the defeat of underground groups. The period was referred to as the "postemergency period' as the Italian state began to reform its own governments to create more cohesion and agreement amongst counterterrorism measures, and the government began to rethink its counterterrorism strategies and reversed the controversial policies of the third period. Legislation created in this period aimed to target the organizational dynamics and internal crises experienced by the various groups. This meant that law enforcement provided convicted and imprisoned members of terrorist groups with the chance to shorten their sentences and/or have their charges dropped if they collaborated. Issues within terrorist organizations led to members revealing their hierarchies and who belonged to their networks, thus spurring mass arrests during this period.

This presented a critical point for counterterrorism measures in Italy, where the state began to treat terrorist groups as separate political entities where their dynamics must be understood in order to effectively combat them. It was evident from the first three periods of the Years of Lead that an efficient and effective counterterrorism strategy could not be implemented "without a profound knowledge of the way terrorist organizations work."154 Della Porta (1992) recommended a supplementary lesson based on Italy's experiences: reconciliation is a necessary step in counterterrorism because the fight against terrorism does not end with the defeat of a group. Following the fourth period, the state had to undergo prison reforms and implement measures that assisted former militants, who eventually resented the organizations they had

\footnotetext{
${ }^{154}$ Donatella della Porta, "Institutional Responses to Terrorism: The Italian Case." Terrorism and Political Violence. 4:4: 168.
} 
aligned with, with reintegration into society. ${ }^{155}$ Italy's experience with applying the reintegrative shaming theory into their counterterrorism strategy during the Years of Lead will be discussed further in this chapter's Part D: Findings and Discussion.

Even though the terrorist organizations of the Years of Lead subscribed to a different ideology compared to jihadist extremists, Italy's experiences with political violence has provided the state with a foundation of counterterrorism measures to build upon.

Italy’s Complicated Relationship with its Muslim Community

Although the presence of Islam in Italy can be traced back to the $13^{\text {th }}$ century when Arabs landed in Sicily in June 875, Islamic communities were virtually non-existent in Italy until the 1960s when the first Muslim immigrants began to arrive to Italy. These groups mostly consisted of students and Arab elites searching for better opportunities; it was not until the 1980s when migration patterns changed and unskilled workers from Muslim countries flooded Italy in response to cheap labour demands ${ }^{156}$. As a result, Italy experienced the mass immigration of the Islamic diaspora rather late compared to other European states in the $20^{\text {th }}$ century. Former European empires engulfed Muslim immigrants from their former colonies and these diasporas are representative of that effect. While Italy did receive immigrants from its former colonies (Eritrea, Somalia, and Libya), only a small percentage of these groups make up the Muslim population in Italy. Muslim immigrants in Italy are mostly from Morocco and Albania (which also account for the second and third largest foreign diasporas in Italy), followed by Tunisia,

\footnotetext{
${ }^{155}$ Donatella della Porta, "Institutional Responses to Terrorism: The Italian Case." Terrorism and Political Violence. 4:4: 167.

${ }^{156}$ Pacini, Andrea. 2001. "Muslims in Italy.” [Italian: "I Musulmani in Italia”] University of Padova, Political Science Faculty, organized by GRIM, Research Group on Islam and Modernization
} 
Senegal, Egypt, Bangladesh, Pakistan, Algeria, Bosnia and Herzegovina, and Nigeria. ${ }^{157}$ In 2015 , Moroccans and Albanians made up one fifth of Italy's total immigrant population.

The diverse Islamic diaspora in Italy has led to fragmented communities across the country and various approaches to Islamic practices within Italy. ${ }^{158}$ With the various nationalities existing within Italy's Islamic community, Roberto Giritti and Magdi Allam questioned "what does it mean to be Muslim in Italy today?". ${ }^{159}$ They identified six branches of religious interpretation: secular Islam, 'ecumenical' Islam, 'apolitical' Islam, orthodox Islam, fundamental Islam, and revolutionary Islam (see the following footnote for descriptions) ${ }^{160}$. Despite the various interpretations and nationalities, five common characteristics can be applied to describe the Islamic community in Italy: the arrival of Islamic immigrants is fairly recent, resulting in many first generation immigrants and slowly moving toward second generation Islamic Italians; there is a wide diversity of the countries of origin; there was a rapid pace of entry and settlement; the community is made up of a higher number of irregular immigrants, and there is a higher level of geographic dispersion. ${ }^{161}$

Italy's Muslim community is estimated to be the fourth largest in Europe, accounting for approximately $3.7 \%$ of the population (est. 2022000$)^{162}$ (in comparison, Roman Catholics account for $94 \%$ of the population). Despite the fact that Muslims in Italy only represent an

\footnotetext{
${ }^{157}$ Lorenzo Vidino 2008 “Islam, Islamism, and Jihadism in Italy.” https://www.hudson.org/research/9813-islam-islamism-andjihadism-in-italy; Karim Mezran 2013 "Muslims in Italy: The Need for an 'Intesa' with the Italian State”. P.60

158 "Ties That Bind: Dynamics of Group Radicalization in Italy's Jihadists Headed for Syria and Iraq" by Francesco Marone 2015,8 .

${ }^{159}$ Gritti, R. and M. Allam. Islam, Italia: Chi sono e cosa pensano i musulmani che vivono tra noi. Milan: Guerini e Associati, 2001.

160 "Secular Islam" describes the majority of the community living in Italy, most who consider integrating into EU society to be very important to them; "Ecumenical Islam" describes those that search for common values with other religions; "Apolitical Islam" describes those that hold a primacy of faith, and excludes the political culture that was widespread among Moroccans and Pakistanis in Italy nearly two decades ago; "Orthodox Islam" is represented by the Lega Islamica Mondiale (English: World Islamic League, sponsored by Saudi Arabia); "Fundamentalist Islam" describes those that believe in Islamising the entire society, and who embrace religious and political components of Islam; and "Revolutionary Islam" describes the Islam of jihad.

${ }^{161}$ Allievi, S. “Islam Italiano e Societa Nazionale”. In Islam in Europa/Islam in Italia. Tra Diritto e Societa', edited by A. Ferrari: 43-77. Bologna: il Mulino, 2008.

${ }^{162}$ Conrad Hackett. "5 Facts about the Muslim Population in Europe.” Pew Research Center. Published on 19 July 2016. http://www.pewresearch.org/fact-tank/2016/07/19/5-facts-about-the-muslim-population-in-europe/
} 
insignificant fraction of the population, Italians do not perceive Muslims favourably. Since 9/11, there has been an increase in Islamophobia across Italy ${ }^{163}$; according to a Pew Research Center study in 2014, Italians were deemed the most critical of Muslims across the EU, resulting in $63 \%$ of Italians with unfavourable views of Muslims in Italy. ${ }^{164}$

In addition to the negative attitudes toward the Muslim population, Italy's complicated relationship with its Muslim community is also represented by the state's failure to recognize Islam through an intesa (plural: "intese"), a bilateral agreement that governs relations between the state and religious minority groups within Italy $^{165}$. While article 8 of the Italian Constitution states that "all religious denominations are equally free before the law"166, Italy operates under a concordat system, meaning that the government requires religious communities to receive an intesa from the state in order to receive legal recognition. ${ }^{167}$ Legal recognition goes beyond permitting religious practices, as it also provides religious minorities with state funding and a forum for dialogue between a religious leader and the Italian state. Due to the lack of recognition, and Italy's difficult process for obtaining citizenship, Muslim immigrants who have more or less integrated into Italian society are referred to as "sociological [Muslim] Italians"168. This maintains a divide between "Italians" and the "others", which often comprise of immigrant minority groups, thus allowing unfavourable views toward the Muslim community to persist.

The Islamic community is not the only religious denomination that has failed to receive recognition (groups without an intesa include various Orthodox groups, Sikhs, among many

\footnotetext{
${ }^{163}$ Karim Mezran, "Muslims in Italy: The Need for an 'Intesa' with the Italian State," 2013, 59.

164 “Chapter 4. Views of Roma, Muslims, Jews,” Pew Research Centre, May 122014. http://www.pewglobal.org/2014/05/12/chapter-4-views-of-roma-muslims-jews/

${ }^{165}$ Karim Mezran, 2013, 64; Casuscelli, G. "La rappresentanza e l'intesa," [English: "Representation and the Agreement"] in Islam in Europa/Islam in Italia. Tra Diritto e Societa '[English: "Islam in Europe/Islam in Italy: Between Law and Society"] edited by A. Ferrari: 285-325. Bologna: il Mulino, 2008.

${ }^{166}$ Costituzione della Repubblicca Italiana https://www.senato.it/documenti/repository/istituzione/costituzione.pdf

${ }^{167}$ Servizio per i rapporti con le confessioni religiose e per la relazioni istituzionali: Le intesse con le confessioni religose http://presidenza.governo.it/USRI/confessioni/intese indice.html

${ }^{168}$ Lorenzo Vidino, "The Evolution of Jihadism in Italy: Rise in Homegrown Radicals," in CTC Sentinel 6:11, 2013.
} 
others; the Italian Buddhist Union and the Italian Hindu Union only received an intesa for their respective groups in 2007), but the failure to provide the Italian Islamic community with an intesa is more than just an issue of Islamophobia, it is also due to the large diversity of the community in Italy. The fragmentation of groups and the various efforts of self-integration, combined with a religion that does not have a clear hierarchal order, has resulted in a community that lacks a leader to deal with the Italian government. While rivalries persist among the different Islamic communities and their various leaders, the Italian state also refuses to deal individually with different Muslim groups. Consultations have occurred since 9/11 to move toward legitimizing Islam in Italy, but the government prefers to deal with the groups informally without granting a single group legitimacy. ${ }^{169}$

The ultimate risk that persists with failing to legitimize and formally cooperate with Italy's Islamic community is two-fold; on the one hand, you have a demographic within Italy that attempts to integrate within society but maintains resentments against the country that will not provide them any legitimacy. On the other hand, if Italy is not willing to legitimize one of its larger religious minorities, and refuses to provide them adequate funding, oversight, and cooperation, external actors will take the Italian government's place. As a result, Saudi Arabia, Egypt's Muslim Brotherhood, and Iran could contribute to ultra-conservative groups and allow them to grow and prosper. This creates the right conditions for radicalization.

Jihadist Extremists in Italy

\footnotetext{
${ }^{169}$ Karim Mezran, "Muslims in Italy: The Need for an 'Intesa' with the Italian State," 2012, 64-66 ; Anna Momigliano, "In Italy, Islam doesn't officially exist. Here's what Muslims must accept to change that,” The Washington Post, 8 February 2017, https://www.washingtonpost.com/news/worldviews/wp/2017/02/08/in-italy-islam-doesnt-officially-exist-heres-what-muslimsmust-accept-to-change-that/?utm term $=.5 \mathrm{c} 83668 \mathrm{a} 850 \mathrm{f}$.
} 
Since Daesh's rise in 2014, the jihadist extremist group has threatened Italy (particularly Rome and the Vatican) on numerous occasions, promising to incite a new era of religious crusades against the Roman Catholic Church. At the time of writing, Daesh has not committed attacks on Italian soil, but they have threatened to attack Italy as recently as August 2017, and a trio of suspected Daesh supporters were arrested late-March 2017 for reportedly planning to blow up the popular Rialto Bridge in Venice. ${ }^{170}$ In addition to the frequent threats primarily targeting Rome and the Vatican, several individuals that are connected to, or support, Daesh have been arrested and/or expelled from Italy.

As one of the first EU countries to develop jihadist cells on its territories, Italy has faced jihadist threats since these cells slowly started forming in the early 1990s (as a result of returning mujahideen fighters from the First Afghanistan War and to export foreign fighters to the Balkans for the "Bosnian jihad"), however, Italy has not been extensively investigated as a case study for domestic jihadism. ${ }^{171}$ According to Europol's 2017 TE-SAT, only 28 arrests in Italy were attributed to jihadist-inspired terrorist threats in 2016. In comparison, France arrested 429 individuals (France was an outlier and had more than four times the arrests compared to other EU states), Spain arrested 69 individuals, and Belgium arrested 62 individuals. ${ }^{172}$ Following the first generation of jihadists in Italy, which consisted of the influx of foreign fighters arriving and departing from Afghanistan and Bosnia, Italy has begun to experience a shift toward homegrown radicalism similar to that of other Western European countries. However, compared to other

\footnotetext{
170 “Terrorismo, la minaccia dell'Isis: 'Prossimo obiettivo è l'Italia'. Viminale espelle 3 stranieri.” [English: "Terrorism, the ISIS threat: 'the next target is Italy'. Viminal expels three foreigners."] La Repubblica 19 August 2017. http://www.repubblica.it/cronaca/2017/08/19/news/paura_terrorismo_espulsi_dall_italia_due_marocchini_e un_siriano$173367567 /$

171 “Ties That Bind: Dynamics of Group Radicalization in Italy's Jihadists Headed for Syria and Iraq” by Francesco Marone 2015,5 .

1722017 EU Terrorism Report page 50: https://www.europol.europa.eu/newsroom/news/2017-eu-terrorism-report-142-failedfoiled-and-completed-attacks-1002-arrests-and-142-victims-died
} 
affected states, homegrown radicalization remains a "small phenomenon" in Italy, and Italian authorities have had success with containing the threat of homegrown radicals. ${ }^{173}$

Shortly following the 9/11 attacks, the U.S. Department of Treasury declared an Italian mosque that was established inside a garage in Milan as "the main Al Qaeda station house in Europe". This mosque, known as the "Viale Jenner Mosque", developed alongside the Istituto Culturale Islamico Milano (ICIM, English: the Islamic Cultural Institution in Milan) when the ICIM was established in 1988. The ICIM itself was created by the Egyptian extremist group alGama'a al-Islamyya (GI) ${ }^{174}$ and its ringleader in Milan, Anwar Shabaan, a radical Imam who led the effort regarding logistics for the Bosnian jihad in the early 1990s from the Viale Jenner Mosque. The Viale Jenner Mosque, which is simply based out of a converted garage, attracted large numbers of worshippers but it quickly became infamous for the radicalized extremists that affiliated themselves with the mosque and the radical Imams that preached there on a regular basis. For many first-generation jihadists (those that fought in the Afghan jihad and many who affiliated themselves with Al Qaeda), unregulated mosques and radical Imams were the primary route for radicalization in the West. While the Viale Jenner Mosque was infamous for its output of jihadist extremists, in general, Italian mosques are not the dominant source of radicalization within Italy. ${ }^{175}$ The extensive use of social media has become an important component of domestic radicalization within Italy, as it has helped develop the network and the cells within the country. ${ }^{176}$ In addition, it has made it easier to disseminate propaganda and attract likeminded recruits.

\footnotetext{
${ }^{173}$ Lorenzo Vidino, "The Evolution of Jihadism in Italy: Rise in Homegrown Radicals," 2013.

${ }^{174}$ Al-Gama'a al- Islamyya is a Sunni Islamist group originating from Egypt dedicated to the goal of overthrowing the Egyptian government and replacing it with an Islamic state. The group was accused of carrying out dozens of violent campaigns in the 1990s against police officers, soldiers, civilians, and tourists. Source: Terrorism Research and Analysis Consortium https://www.trackingterrorism.org/group/al-gamaat-al-islamiyya-gi accessed August 2017

${ }^{175}$ Vidino, Il jihadismo autoctono in Italia, 2015, 81-82. www.ispionline.it/it/Ebook/Il jihadismo autoctono in Italia.pdf

${ }^{176}$ Vidino, Il jihadismo autoctono in Italia, 2015, 84.
} 
The common profile of Europe's jihadist extremists, particularly those in recent years, is well known at this point. They are young males, second or third generation immigrants, many of who live in ghettoized communities, and they have a history of criminal behavior. Of course, there are exceptions and these generalized characteristics do not, and should not, typecast all individuals who may share those traits. Additionally, European jihadists have also included a substantial number of female foreign fighters (17\% according to data based on eleven EU member states accounting for $80 \%$ of foreign fighters as of late-2015) and it is believed that converts to Islam comprise anywhere from 6-23\% of foreign fighters (based on data from three member states accounting for $51 \%$ of foreign fighters as of late-2015). ${ }^{177}$

Italy's late transformation from a country of emigration to immigration has led to a smaller population of second and third generation immigrants that live among the rest of the Italian population because the urban landscape has not pushed out the immigrants to segregated communities. However, this second generation of Italian-born Muslims are becoming of age and it will only become evident in the coming years whether there will be a threat posed to the same extent as countries like Belgium, France, Germany, the UK, or Sweden. ${ }^{178}$ As a result of late second-generation, the typology of Italian jihadists has been different compared to other EU states. For one, Italy has seen a larger number of Balkan jihadists than other EU states, which is primarily due to the country's larger Albanian/Kosovar population and its role in the Bosnian jihad in the 1990s. Despite this single characterizing factor, jihadism in Italy is extremely fragmented and diverse, and it includes a combination of both immigrants whose families are Muslim, and converts to the religion, along with both foreigners who are new to the country and

\footnotetext{
177 "The Foreign Fighters Phenomenon in the Euopean Union: Profiles, Threats \& Policies." International Centre for CounterTerrorism - The Hague. April 2016.

${ }^{178}$ Lorenzo Vidino, "Report: Home-Grown Jihadism in Italy," Istituto per gli Studi di Politica Internazionale, 29 April 2014. www.ispionline.it/it/pubblicazione/home-grown-jihadism-italy-10309
} 
Italians who are citizens by heritage or naturalized. Unlike other European countries, issues of discrimination and lack of socio-economic integration do not seem to be the primary reasons for radicalization in Italy, but these elements should not be overlooked, and Italy should carefully examine the cases of its neighbours to prevent these factors from contributing to future extremists. $^{179}$

The policy analysis conducted for this thesis examines a subset of Italian legislation regarding the trends of its counterterrorism measures, particularly how they compare to the EU standards and the Italian-specific trends in counterterrorism. The conclusion will highlight the effective aspects of Italian counterterrorism efforts, its problematic areas, and what Italy can learn from other EU states to prevent the future generations from radicalizing in large numbers.

\section{GENERAL OVERVIEW OF QUALITATIVE ANALYSIS OF ITALY'S} COUNTERTERRORISM MEASURES (2001-2016)

Legislation pertaining to various counterterrorism measures appears to be ubiquitous, particularly since the extreme securitization of terrorism following the $9 / 11$ attacks in the United States. Italy was not exempt from this phenomenon and followed the footsteps of its allies by producing and amending its counterterrorism measures, which included revisiting legislation that was drafted during and immediately succeeding the Years of Lead. The findings of this chapter have resulted from a qualitative analysis of Italian counterterrorism measures produced between 2001 and 2016. The methodology of this analysis can be found in Chapter II; due to various research constraints, the analysis only examined measures that contained the word "terrorism" in the title of the legislation, in order to ensure that the legislation was specifically about

\footnotetext{
${ }^{179}$ Lorenzo Vidino, Il jihadismo autoctono in Italia [English: "Homegrown Jihadism in Italy"], (Milan: ISPI Publications 2015), 99-102 ; Lorenzo Vidino et al., Fear Thy Neighbour (Milan: ISPI Publications 2015), 77-82.
} 
counterterrorism. This resulted in the analysis of 28 pieces of legislation passed by the Italian government (not including the Criminal Code of Italy, which was introduced prior to 2001 but has undergone numerous provisional amendments), with the first being introduced months before 9/11 on 14 March $2001^{180}$, while the final measure analyzed was introduced on 28 July $2016 .^{181}$

The remainder of this chapter will focus on the conclusions drawn from the Italian policy analysis, beginning with an overview of the general trends identified in Italian counterterrorism measures during the selected timeframe. Afterward, the findings regarding three main themes that surfaced from the policy analysis will be discussed as they are specific to the Italian case, but they are also lessons that could be applied to the EU case. These themes include (1) Italy's broad counterterrorism legislation and lack of harmonization with the EU's counterterrorism measures; (2) a specific Italian counterterrorism tactic, which involves either deporting foreign individuals convicted or suspected of engaging in terrorist activities, or offering them the option of remaining in Italy in favour of their collaboration with law enforcement; and (3) applying and combining anti-mafia measures with counter-terrorism measures, and enforcing a criminological understanding of deterrence theory within their counterterrorism efforts.

\footnotetext{
${ }^{180}$ DECRETO DEL PRESIDENTE DELLA REPUBBLICA 14 marzo 2001, n. 318 Regolamento recante disciplina per l'assegnazione delle borse di studio in favore delle vittime del terrorismo e della criminalita', nonche' degli orfani e dei figli delle vittime del terrorismo. [English: "DECISION OF THE PRESIDENT OF THE REPUBLIC of 14 March 2001, no. 318 Regulation laying down discipline for granting scholarships in favor of victims of terrorism and crime, as well as of orphans and children of victims of terrorism. ']

${ }^{181}$ LEGGE 28 luglio 2016, n. 153 Norme per il contrasto al terrorismo, nonche' ratifica ed esecuzione: a) della Convenzione del Consiglio d'Europa per la prevenzione del terrorismo, fatta a Varsavia il 16 maggio 2005; b) della Convenzione internazionale per la soppressione di atti di terrorismo nucleare, fatta a New York il 14 settembre 2005; c) del Protocollo di Emendamento alla Convenzione europea per la repressione del terrorismo, fatto a Strasburgo il 15 maggio 2003; d) della Convenzione del Consiglio d'Europa sul riciclaggio, la ricerca, il sequestro e la confisca dei proventi di reato e sul finanziamento del terrorismo, fatta a Varsavia il 16 maggio 2005; e) del Protocollo addizionale alla Convenzione del Consiglio d'Europa per la prevenzione del terrorismo, fatto a Riga il 22 ottobre 2015. [English: "LAW 28 July 2016, no. 153 Standards for countering terrorism, as well as ratification and execution: a) of the Council of Europe Convention for the Prevention of Terrorism, done in Warsaw on 16 May 2005; (b) of the International Convention for the Suppression of Nuclear Terrorism, done at New York on 14 September 2005; (c) of the Protocol to the European Convention for the Suppression of Terrorism, done at Strasbourg on 15 May 2003; (d) of the Council of Europe Convention on Laundering, Search, Seizure and Confiscation of proceeds of crime and the financing of terrorism, done at Warsaw on 16 May 2005; (e) of the Additional Protocol to the Council of Europe Convention for the Prevention of Terrorism, done at Riga on 22 October 2015.’]
} 
General trends and an overview of the policy analysis

Specific themes were identified in this analysis, which will be discussed in the subsequent section, but several broad trends also surfaced as a result of the analysis' findings. Given that one of the purposes of this thesis is to examine how Italian counterterrorism measures compare to the EU, several core questions were evaluated, which are illustrated in the following figures:

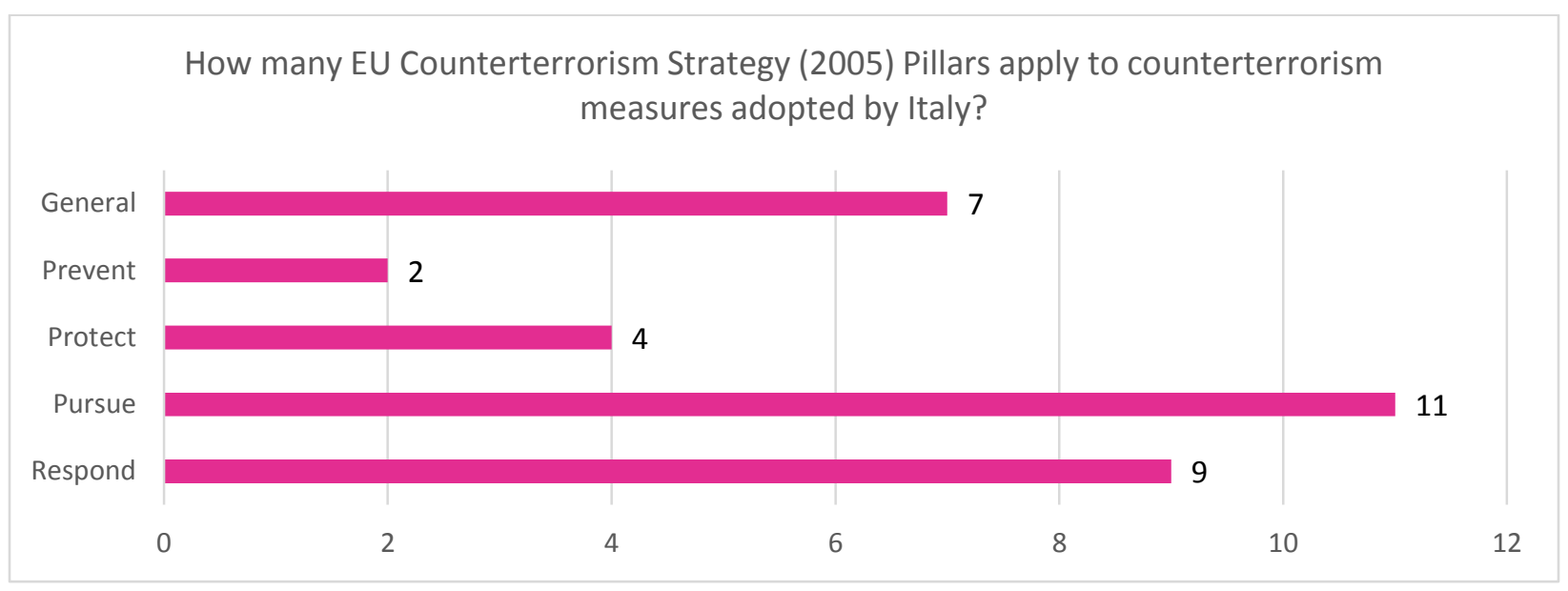

Figure 5.1 Counterterrorism Strategy Pillars applicable to Italian counterterrorism measures. Data extracted from qualitative policy analysis derived from legislation (2001-2016) found on normattiva.it. While 28 pieces of legislation were examined, the above data amounts to 33 because five measures fell into two categories. Chart self-produced following this research's policy analysis of the 28 Italian measures, which are listed in Annex A. 
IS THE EU'S DEFINITION OF TERRORISM APPLIED?

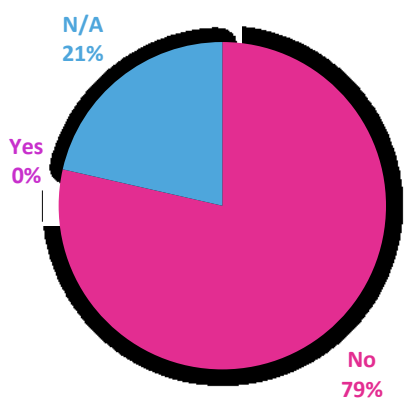

Figure 5.2 Application of the EU definition of "terrorism" in Italian counterterrorism measures. N/A results applied to legislation that was enacted prior to 2002, when the EU's definition was written into the Framework Decision 2002/475/JHA.

Chart self-produced following this research's policy analysis of the 28 Italian measures, which are listed in Annex A.

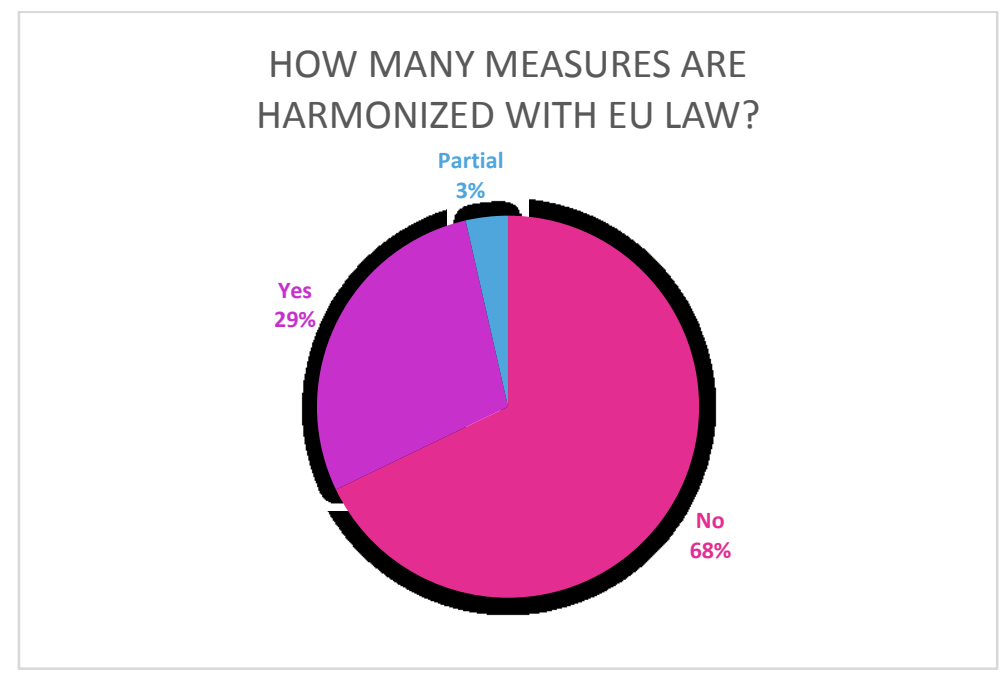

Figure 5.3 Italian counterterrorism measures harmonized with EU law. Chart self-produced following this research's policy analysis of the 28 Italian measures, which are listed in Annex $A$

This thesis argues that counterterrorism measures are ineffective primarily due to the lack of policies that fall under the PREVENT pillar of the EU's Counterterrorism Strategy (CTS). This thesis also hypothesized that there is a lack of preventative measures inscribed in enforceable legislation. Figure 5.1 illustrates that this hypothesis is correct in the Italian case, as much as it is for the EU case (which will be shown in the following chapter). Only two measures 
that were passed by the Italian Parliament fell under the PREVENT pillar (this includes all Italian-specific legislation and legislation passed in order to comply with the EU standards), which includes Decreto-Legge 29 dicembre 2007, n.249 (English: "Decree-Law 29 December 2007, n.249”) ${ }^{182}$ and Legge 28 luglio 2016, n.153 (English: "Law 28 June 2016, n.153”). ${ }^{183}$ The latter policy, N.123/2016 focuses on the prevention and suppression of nuclear terrorism specifically, with no provisional measures that addresses the key points of the EU's PREVENT pillar (this pillar addresses the behavior and motivations of individuals and seeks to develop measures to prevent individuals from radicalizing and partaking in terrorist groups and activities). The former policy, N.249/2007, is particular to Italy because it is the legislation governing the deportation of individuals suspected or convicted on charges for participation or support of terrorist activities. N.249/2007 falls under the PREVENT pillar (along with PURSUE) because it serves as a reason for non-Italian nationals to not engage, participate, or support terrorist activities. This policy will be further examined in Section E of this chapter. Although the analysis for this thesis only reviews policies enacted between 2001 and 2016, it should be noted that Italy's Lower House of Parliament passed a bill in the summer of 2017 introducing

\footnotetext{
${ }^{182}$ DECRETO-LEGGE 29 dicembre 2007, n. 249 "Misure urgenti in materia di espulsioni e di allontanamenti per terrorismo e per motivi imperativi di pubblica sicurezza." (GU n.1 del 02-01-2008) (English: "DECREE-LAW 29 December 2007, no. 249 'Urgent measures on extradition and expulsion for terrorism and for imperative reasons of public security."') http://www.camera.it/parlam/leggi/decreti/07249d.htm

${ }^{183}$ LEGGE 28 luglio 2016, n. 153 "Norme per il contrasto al terrorismo, nonche' ratifica ed esecuzione: a) della Convenzione del Consiglio d'Europa per la prevenzione del terrorismo, fatta a Varsavia il 16 maggio 2005; b) della Convenzione internazionale per la soppressione di atti di terrorismo nucleare, fatta a New York il 14 settembre 2005; c) del Protocollo di Emendamento alla Convenzione europea per la repressione del terrorismo, fatto a Strasburgo il 15 maggio 2003; d) della Convenzione del Consiglio d'Europa sul riciclaggio, la ricerca, il sequestro e la confisca dei proventi di reato e sul finanziamento del terrorismo, fatta a Varsavia il 16 maggio 2005; e) del Protocollo addizionale alla Convenzione del Consiglio d'Europa per la prevenzione del terrorismo, fatto a Riga il 22 ottobre 2015." (16G00165) (GU n.185 del 09-08-2016 - Suppl. Ordinario n. 31 ) (English: "LAW 28 July 2016, no. 153 'Standards for countering terrorism, as well as ratification and execution: a) of the Council of Europe Convention for the Prevention of Terrorism, done in Warsaw on 16 May 2005; (b) of the International Convention for the Suppression of Nuclear Terrorism, done at New York on 14 September 2005; (c) of the Protocol to the European Convention for the Suppression of Terrorism, done at Strasbourg on 15 May 2003; (d) of the Council of Europe Convention on Laundering, Search, Seizure and Confiscation of proceeds of crime and the financing of terrorism, done at Warsaw on 16 May 2005; (e) of the Additional Protocol to the Council of Europe Convention for the Prevention of Terrorism, done at Riga on 22 October 2015.'”)
} 
"measures for the prevention of jihadist radicalization and extremism" ${ }^{184}$, which is based on a non-binding November 2015 resolution by the European Parliament on preventing radicalism. ${ }^{185}$

Figures 5.2 and 5.3 also address how closely Italian counterterrorism policy follows EU policy. First, it is evident that the EU's definition of 'terrorism' is not referred to once in any of the legislation, nor does any of the legislation redirect a reader to the policy that contains the definition (the EU's definition of terrorism, which was addressed at the beginning of this thesis, can be found in Annex $\mathrm{C}$ of this thesis and it is derived from Article 1 of the Council Framework Decision 2002/475/JHA ${ }^{186}$ ). Legislation that is harmonized with the EU and is related to preventing terrorism financing contains definitions for various terms regarding money laundering, but nothing specifying terrorism itself. Despite the lack of reference or direction to the definition of terrorism in Italian legislation, the Italian criminal code has adopted the EU's definition of terrorism in Article $270^{187}$ (the article itself was first established following the Years of Lead) because of the principle of subsidiarity invoked in the Framework Decision 2002/475/JHA. This includes all three parts of the EU's definition on terrorist offences, where terrorist offences aim to (i) intimidate a population, (ii) unduly compel a government or

\footnotetext{
${ }^{184}$ Misure per la prevenzione della radicalizzazione e dell'estremismo violento di matrice jihadista A.C. 3558-A (English:

"Measures for the Prevention of Jihadist Radicalism and Violent Extremism"). http://documenti.camera.it/Leg17/Dossier/Pdf/AC0573A.Pdf

${ }^{185}$ European Parliament Resolution of 25 November 2015 on the Prevention of Radicalization and Recruitment of European Citizens by Terrorist Organizations. http://www.europarl.europa.eu/sides/getDoc.do?pubRef=$\% 2 \mathrm{f} \% 2$ fEP $\% 2 \mathrm{f} \% 2$ fTEXT\%2bTA $\% 2$ bP 8 -TA-2015-0410\%2b0\%2bDOC $\% 2 \mathrm{bXML} \% 2 \mathrm{bV} 0 \% 2 \mathrm{f} \% 2 \mathrm{fIT}$

${ }^{186}$ Decisione quadro del Consiglio, del 13 giugno 2002, sulla lotta contro il terrorismo Gazzetta ufficiale n. L 164 del 22/06/2002 pag. 0003 - 0007 (English: "Council Framework Decision of 13 June 2002 on combating terrorism”) http://eurlex.europa.eu/legal-content/IT/TXT/?uri=CELEX:32002F0475

${ }^{187}$ Article 270 of Italy's Criminal Code states, "sono considerate con finalità di terrorismo le condotte che, per la loro natura o contesto, possono arrecare grave danno ad un Paese o ad un'organizzazione internazionale e sono compiute allo scopo di intimidire la popolazione o costringere $i$ poteri pubblici o un'organizzazione internazionale a compiere o astenersi dal compiere un qualsiasi atto o destabilizzare o distruggere le strutture politiche fondamentali, costituzionali, economiche e sociali di un Paese o di un'organizzazione internazionale, nonché le altre condotte definite terroristiche o commesse con finalità di terrorismo da convenzioni o altre norme di diritto internazionale vincolanti per l'Italia" (English: "[activities] are considered for purposes of terrorism conduct that, by their nature or context, can cause serious damage to a country or to an international organization and is carried out in order to intimidate the population, or to force the public authorities or an international organization to take or refrain from taking any act or to destabilize or destroy the fundamental, constitutional, economic and social structures of a country or an international organization, as well as any other terrorist or terrorist conduct committed or intended for terrorism purposes by conventions or other rules of international law binding on Italy.")
} 
international organization from performing or abstaining from an act, and (iii) seriously destabilizes and/or destroys the fundamental processes of a country or international organization. Additionally, the Italian Constitution includes a provision that closely describes the state's views on terrorist and criminal organizations, based on Italy's historical experiences. Article 18 of the constitution declares that secret societies that directly or indirectly pursue political objectives via self-organized military organizations are forbidden. ${ }^{188}$

While there is a uniform application of the definition for "acts of terrorism", there is still a failure at the European level, and thus the member state level, to acknowledge how terrorism and terrorist can be defined. The definition for offences strictly acknowledge the general aims of terrorist activities (thus looking at the output results), and additionally highlighting what activities are deemed to be terrorist offences exactly (including kidnapping, hostage taking, seizure of transport, attacks upon the physical integrity of a person, damages that may result in death, extensive damage to critical infrastructure and anything that results in great economic loss). However, the EU's definition of terrorist offences, which by extension is the Italian definition, follows the pattern of other countries and organizations by failing to define what a 'terrorist' is specifically at the individual level. Politically, this is challenging because there is no accepted definition, and there are nuances that are difficult to address (such as the line between "good" radical ideas and "bad" radical ideas, in addition to the debate between the term "freedom fighter" versus "terrorist" and the subjectivity surrounding both debates). National governments and international organizations are doing themselves a disservice by failing to tread these difficult waters and acknowledge the complexity of the terrorist phenomenon. Italy had

\footnotetext{
${ }^{188}$ Article 18 of Italy's Constitution states, "Sono proibite le associazioni segrete e quelle che perseguono, anche indirettamente, scopi politici mediante organizzazioni di carattere militare" (English: "secret societies and those who pursue, even indirectly, political purposes by military organizations are forbidden") in Costituzione della Repubblica Italiana, in Gazzetta Ufficiale, $\mathrm{n}^{\circ}$ 298, Roma, Istituto Poligrafico dello Stato, dicembre 1947, pp. 3801-3816. URL consultato il 10 dicembre 2016.
} 
previously attempted to arrive to a consensus on its own definition of "terrorism", but the working group responsible for this task refused to propose a definition and decided to recognize the progress made by the United Nations Security Council Resolution 1566 that states terrorist attacks are never justified on political, ideological, racial, ethnic, or other reasons. ${ }^{189}$

Additionally, figure 5.3 illustrates that nearly a third of Italian legislation is either completely $(29 \%)$ or partially $(3 \%)$ harmonized with the EU (this equates to nine pieces of legislation examined in this analysis). Out of these nine legislations, seven were financially related laws aiming to prevent the financing of terrorist organizations, preventing money laundering, and amendments on earlier laws on terrorism financing. In addition to the EU's binding directives, regulations, and decisions, the various bodies of the EU have produced numerous recommendations on various counterterrorism measures for member states to implement if they choose. This is because the EU continues to have limited competencies in the fields of foreign, security, and defence policies. By examining Italy's existing counterterrorism measures, it is evident that only one of the two policy areas that the EU is most proficient at within counterterrorism (economic and border policies) are implemented at the Italian level, and that is because the principle of subsidiarity applies to those laws. Despite the number of border security policies adopted by the EU that were directly related to counterterrorism, the examined Italian legislation did not reference any of those policies. It should be noted that Italy is not being deviant by only incorporating a subset of European counterterrorism policy to their own national policy; as a founding member state since the creation of the EU's original institutions, Italy has

\footnotetext{
${ }^{189}$ Yonah Alexander. Counterterrorism Strategies: Success and Failures of Six Nations.
} 
always been supportive of European integration and multilateral institutions, and these principles serve as fundamental pillars to Italy's defence strategy. ${ }^{190}$

Throughout the qualitative analysis, this research also aimed to identify the themes of the analyzed counterterrorism policies. The chart below summarizes these findings:

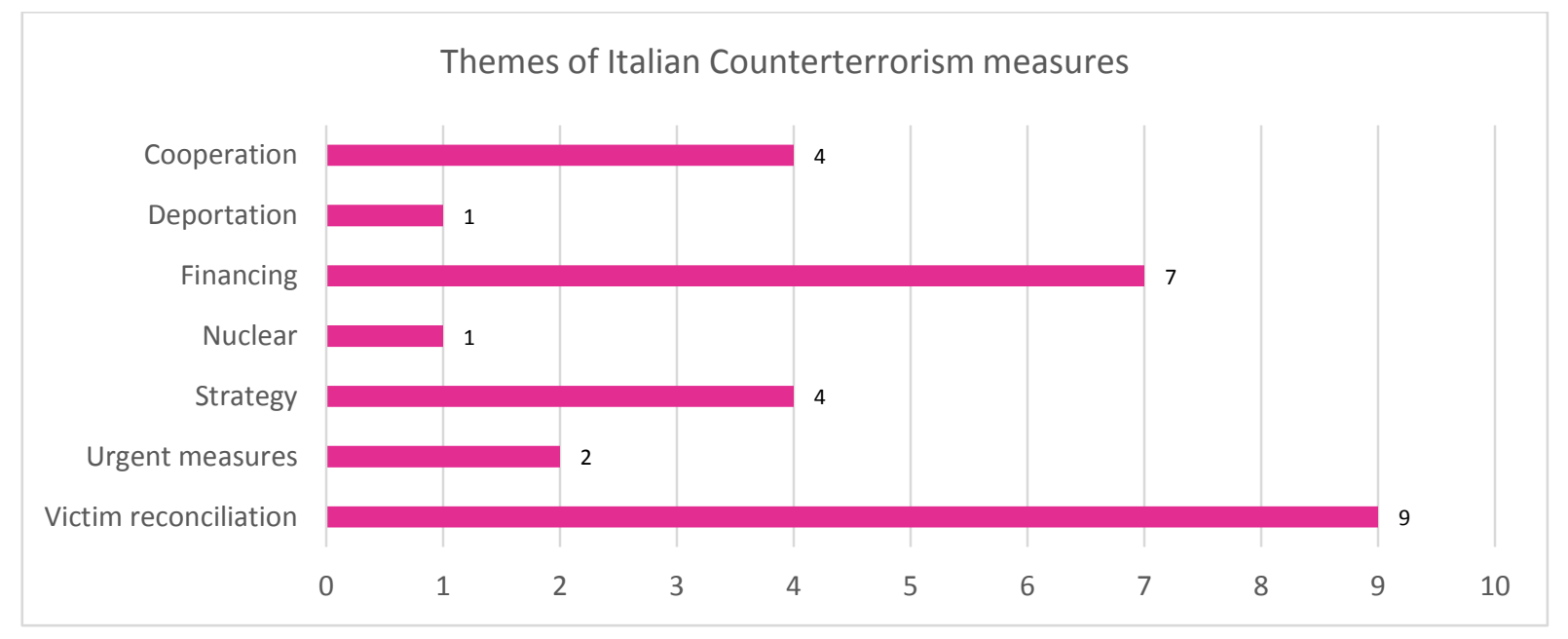

Figure 5.4 Chart self-produced following this research's policy analysis of the 28 Italian measures, which are listed in Annex A.

Out of the 28 laws examined, nine were amendments made with additional provisions. It is interesting to highlight that over half (57\%) of Italy's counterterrorism measures enforced between 2001 and 2016 have aimed to tackle terrorism financing or to assist in victim reconciliation, thus account for nearly all of the policies that fall under the PURSUE or RESPOND pillars of the EU's Counterterrorism Strategy. The seven measures aiming to cease financing of terrorist groups are based on EU directives that implement economic sanctions against specific terrorist groups and individuals partaking in terrorist groups and activities. Only one legislative act was enacted that mandates the deportation of foreign individuals for "security" reasons ${ }^{191}$; this will be further discussed in the subsequent section.

\footnotetext{
190 Ministero degli Affari Esteri e della Cooperazione Internazionale, 'Rapporto 2020. Le scelte di politica estera', April 2008; Capo di Stato Maggiore della Difesa, Il Concetto Strategico del Capo di Stato Maggiore della Difesa (Rome: MAECI, 2005).

${ }^{191}$ DECRETO-LEGGE 29 dicembre 2007, n. 24 Misure urgenti in materia di espulsioni e di allontanamenti per terrorismo e per motivi imperativi di pubblica sicurezza. (GU n.1 del 02-01-2008) (English: "DECREE-LAW 29 December 2007, no. 249
} 
The general trends discussed in this portion of this chapter have generated results that geared toward this thesis' argument regarding the extent of policy harmonization in the EU. While Italy has been doing its due diligence by transposing the EU's financial directives into national law, none of the laws enacted between 2001-2016 were based on EU proposals or recommendations. Besides acts prohibiting financing of terrorism and sanctions of specific individuals and groups, a sizeable portion of the EU's adopted counterterrorism measures are related to border security, one of the few areas in security policy where the EU can produce binding legal acts.

However, based on the analysis conducted in the previous chapter on counterterrorism measures in the EU's legal acts, it was determined that all of the acts regarding border security fall under various decisions made by the Council of the European Union. These decisions are binding legal acts that do not apply to the entire Union, rather, they apply to selective member states, governments, companies and/or individuals. Decisions do not require transposition into national law. Therefore, border security decisions have only applied in case-by-case situations, preventing a uniform approach to border security across the Union. This has exceptional ramifications for a country such as Italy, where the majority of its borders are porous and surrounded by the Mediterranean Sea. Additionally, Italy's proximity to Northern Africa, particularly Libya, has resulted in a substantial number of migrants and asylum seekers landing in Italy. ${ }^{192}$ Despite arguments that large numbers of migrants increases the chances of terrorist activities, Italy's lack of jihadist attacks has disproven this theory. The migration crisis in Europe in the last few years has made it evident that although the EU is attempting to create a single

\footnotetext{
'Urgent measures on extradition and expulsion for terrorism and for imperative reasons of public security.'” http://www.camera.it/parlam/leggi/decreti/07249d.htm

${ }^{192}$ Over 123000 people applied as asylum seekers in Italy throughout 2016 (Asylum Information Database: http://www.asylumineurope.org/reports/country/italy/statistics).
} 
border policy, particularly for external borders, this is still managed specifically by the nation states themselves.

The following section will explore some of Italy's more specific counterterrorism legislation and its preventative strategies, before concluding how deterrence theory has been applied to produce effective results.

\section{FINDINGS AND DISCUSSION}

General trends were identified in the policy analysis for the Italian case study that provided an overall image of what counterterrorism measures have looked like in Italy since 2001. Most of the measures adopted have been routine acts prohibiting financing terrorist organizations and acts, sanctioning specific individuals and groups, and ensuring justice for victims. Between these routine measures that are common across the Union, there are several policies that should be underlined because they are specific to Italy and likely contribute to the positive outcome of their counterterrorism measures.

\section{Options for Those Convicted of Terrorism Offences - Deportation or Collaboration}

Italy's experiences with far-left and far-right terrorism during the Years of Lead and countering organized crime have served as the basis for Italy's approach to counterterrorism, which some have described as an "aggressive" approach. ${ }^{193}$ Many of the counterterrorism measures that have been adopted or amended since 2001 were based on laws that previously

\footnotetext{
${ }^{193}$ Francesco Marone. March 2017. "The Use of Deportation in Counter-Terrorism: Insights from the Italian Case.” International Centre for Counter-Terrorism - The Hague. https://icct.nl/publication/the-use-of-deportation-in-counter-terrorism-insights-fromthe-italian-case/; Lorenzo Vidino. 2008. "Islam, Islamism, and Jihadism in Italy." Hudson Institute. https://www.hudson.org/research/9813-islam-islamism-and-jihadism-in-italy; C. Austin, R. (2007). The New Constitutionalism, Terrorism, and Torture. Current Legal Problems. 60. 79-120. 
targeted the Italian mafias, and the laws themselves gave Italian law enforcement broad powers to combat organized crime in the country. ${ }^{194}$ One of the primary measures that has produced effective results in Italy's counterterrorism efforts is the power to deport foreign citizens for reasons of national security. This subsection will explain the deportation measure exercised by Italy, the evolution of the law itself, followed by how collaboration with suspects plays a role in counterterrorism efforts. A brief evaluation of the benefits and risks of this measure will also be discussed.

Deportations in Italy are performed as "administrative deportations", a form of administrative measures, which are becoming more prevalent in counterterrorism efforts. The term "administrative measures" itself is vague and not well defined, despite that more states are adopting such measures for the purposes of countering terrorism on their own territory. A recent definition crafted states that administrative measures are domestic restrictive measures decided upon and ordered by the executive body to prevent terrorism, often without a judicial process. ${ }^{195}$ This definition encompasses the fundamental aspects of administrative measures, namely that the executive dictates and enforces the measures without the judicial body, thus ensuring quicker executions of the decisions.

The provisions for immigration, including provisions for deporting foreign citizens, are mandated in the Testo unico sull'immigrazione (English: "Unified text on immigration), Legislative Decree No.286/1998. This legislative decree was not examined in this thesis' policy analysis, but its subsequent amendments were included. ${ }^{196}$ The Legislative Decree N.286/1998

\footnotetext{
${ }^{194}$ F. Marone. 2017. "The Use of Deportation in Counter-Terrorism: Insights from the Italian Case."

${ }^{195}$ Bérénice Boutin. December 2016. "Administrative Measures against Foreign Fighters: In Search of Limits and Safeguards." International Centre for Counter-Terrorism - The Hague. https://icct.nl/wp-content/uploads/2016/12/ICCT-BoutinAdministrative-Measures-December2016-1.pdf

${ }^{196}$ Amendments made in DECRETO-LEGGE 27 luglio 2005, n. 144 Misure urgenti per il contrasto del terrorismo internazionale. (English: “DECREE-LAW 27 July 2005, no. 144 Urgent measures to counter international terrorism.”) (GU n.173
} 
provided powers to the Minister of Interior to order the deportation of foreign nationals for reasons of "public order or State security", and foreign nationals can include minors (on the decision of the juvenile court) and close family members of Italian nationals (such is the case of Tunisian-national Hosni Hachemi Ben Hassen ${ }^{197}$, who was sent back to Tunis in July 2016 even though his wife is an Italian citizen). All deportations must be based upon reasonable fact and law.

In the 2005 amendments to the legislative decree, which were made as part of the urgent measures passed soon after the London attacks in July 2005, additional powers were granted to the Minister of Interior, allowing them to deport foreign citizens based on reasonable grounds leading to the conclusion that the individual's activities and/or behaviours can, in any way, facilitate terrorist activities and organizations at the national or international level. ${ }^{198}$ The provisions on deportations were once again amended and expanded in April 2015, shortly following the January 2015 attacks in Paris. The new provisions now included pericolosità sociale (English: "social dangerousness") as reasonable grounds for deporting foreign citizens. ${ }^{199}$ This provision for deportation fits with the discipline of preventative measures used for mafia

del 27-07-2005 ) http://www.camera.it/parlam/leggi/decreti/05144d.htm ; LEGGE 31 luglio 2005, n. 155 Conversione in legge, con modificazioni, del decreto-legge 27 luglio 2005, n. 144, recante misure urgenti per il contrasto del terrorismo internazionale. (English: "LAW 31 July 2005, no. 155 Conversion into law, with modifications, of Decree-Law no. 144, urging urgent measures to counter international terrorism. ") (GU n.177 del 01-08-2005 ) http://gazzette.comune.jesi.an.it/2005/177/3.htm ; and LEGGE 17 aprile 2015, n. 43 Conversione in legge, con modificazioni, del decreto-legge 18 febbraio 2015, n. 7, recante misure urgenti per il contrasto del terrorismo, anche di matrice internazionale, nonche' proroga delle missioni internazionali delle Forze armate e di polizia, iniziative di cooperazione allo sviluppo e sostegno ai processi di ricostruzione e partecipazione alle iniziative delle Organizzazioni internazionali per il consolidamento dei processi di pace e di stabilizzazione. (English: "LAW 17 April 2015 , n. 43 Conversion into law, with modifications, of the decree-law of February 18, 2015, n. 7 on urgent measures to counter terrorism, including an international matrix, as well as the extension of the international missions and police missions, development cooperation initiatives and support for reconstruction processes and participation in the initiatives of international organizations for consolidation of peace and stabilization processes.”) (15G00060) (GU n.91 del 20-04-2015)

197 "Terrorismo:annullate condanne jihadisti." Quotidiano. Published on 15 July 2016. http://www.quotidiano.net/cronaca/terrorismo-annullate-condanne-jihadisti-1.2349194

${ }_{198}$ Article 3 in "LEGGE 31 luglio 2005, n. 155 Conversione in legge, con modificazioni, del decreto-legge 27 luglio 2005 , n. 144 , recante misure urgenti per il contrasto del terrorismo internazionale."

${ }^{199}$ LEGGE 17 aprile 2015, n. 43 Conversione in legge, con modificazioni, del decreto-legge 18 febbraio 2015, n. 7, recante misure urgenti per il contrasto del terrorismo, anche di matrice internazionale, nonche' proroga delle missioni internazionali delle Forze armate e di polizia, iniziative di cooperazione allo sviluppo e sostegno ai processi di ricostruzione e partecipazione alle iniziative delle Organizzazioni internazionali per il consolidamento dei processi di pace e di stabilizzazione. 
suspects, demonstrating the continuous merging of anti-mafia and anti-terrorism policies in Italy.

These aforementioned policies regulate the deportation of non-EU foreign citizens in Italy; separate norms, which are found in Legislative Decree No.30/2007, regulate the rules of deportation of EU citizens who are not Italian. These regulations are more favourable for the targeted individual and the individual is subjected to a judicial process. ${ }^{200}$

Once again, one of the defining features characterizing Italy's relatively low jihadist threat is attributed to the smaller population size of second and third generation immigrants in Italy, particularly compared to other EU member states such as France, Belgium, and the UK. As a result, the ratio between law enforcement resources (which includes various intelligence agencies and police forces at different levels) and individuals suspected of terrorism is skewed in favour of law enforcement in Italy, unlike in other EU countries where resources are tight and the numbers of suspected individuals are too high to monitor each of them carefully. Italy's ratio has warranted that the country's law enforcement can focus on foreign citizens who have not obtained Italian citizenship, thereby ensuring that a threat is prevented and the suspect is expelled from the country before a threat or attack can manifest.

Italy has made extensive use of administrative deportations, as can be seen in Figure 5.5 below, particularly since the Daesh's self-proclamation of their Caliphate in June 2014. The surge in administrative deportations could additionally be credited to Angelino Alfano, who served as Minister of Interior from 2013 until the end of 2016, and had made Italy's counterterrorism and expulsion program his signature issue. ${ }^{201}$ The lack of attacks on Italian soil

\footnotetext{
${ }^{200}$ DECRETO LEGISLATIVO 6 febbraio 2007, n. 30 Attuazione della direttiva 2004/38/CE relativa al diritto dei cittadini dell'Unione e dei loro familiari di circolare e di soggiornare liberamente nel territorio degli Stati membri. (English: "Legislative Decree 6 February 2007, n.30 Implementation of Directive 2004/38 / EC on the right of citizens of the Union and their family members to move and reside freely within the territory of the Member States.") http://www.esteri.it/mae/normative/normativa consolare/visti/d lgs 30 2007.pdf

${ }^{201}$ Giulia Paravicini. "From mafia to terror, the Italian way.” Politico Europe. Published on 3 November 2016. https://www.politico.eu/article/operation-expulsion-italys-controversial-counterterrorism-strategy-tunisian-imam-civil-liberties/
} 
seem to support that this measure has been an important factor in preventing attacks in Italy, despite that some of the original jihadist networks developed in Italy and there is a persistent threat made by Daesh and its supporters against Rome and the Vatican. Additionally, it has been concluded that administrative deportations have resulted in effective counterterrorism results for Italy. $^{202}$

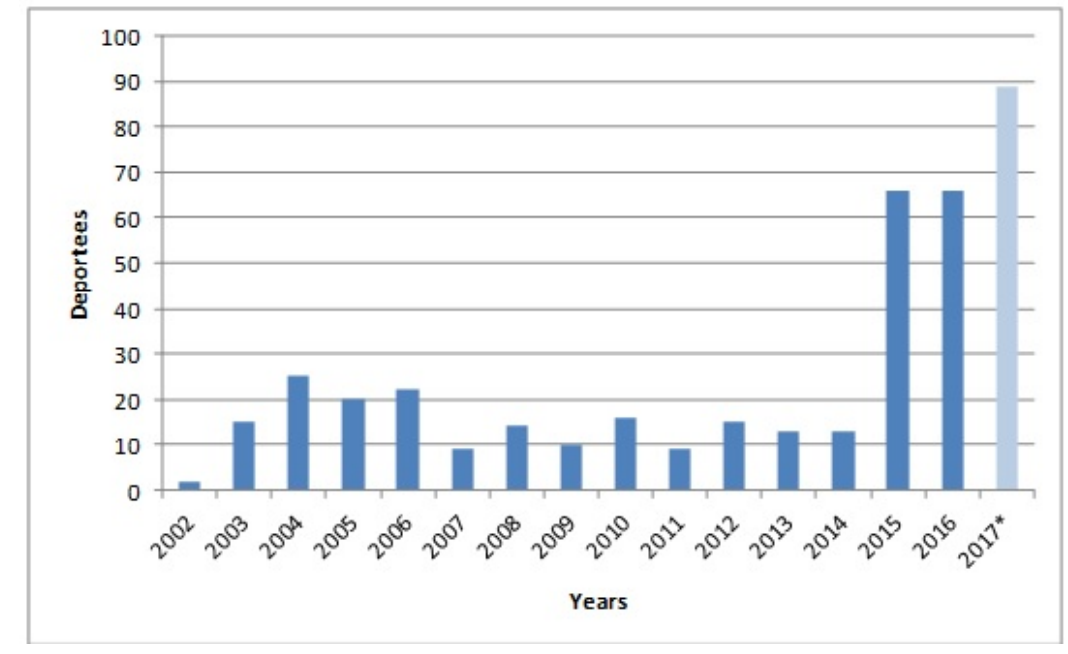

Figure 5.5: Foreign citizens deported from Italy for reasons of security, 2002 - 31 October 2017

(Source: Italian Ministry of Interior)

One of the primary benefits of administrative deportations can be seen as a two-fold preventative measure. On the one hand, fast tracked deportations serve as a means to prevent criminal networks from proliferating and gaining momentum within Italy. ${ }^{203}$ The deportation of suspected individuals is akin to detecting cancerous cells early in the body - the sooner you eliminate the cells, the more likely you are to prevent the cancer from spreading and becoming a deadly detriment. This also makes monitoring and surveillance of suspects easier for the Italian

\footnotetext{
${ }^{202}$ Francesco Marone. August 2016. "Italy's Jihadists in the Syrian Civil War.” Internaional Centre for Counter-Terrorism - The Hague. Page 7. https://icct.nl/wp-content/uploads/2016/08/ICCT-Marone-Italys-Jihadists-in-the-Syrian-Civil-War-August2016$1 . \mathrm{pdf}$

$\frac{1.3}{203}$ Marone. 2016. "Italy’s Jihadists in the Syrian Civil War."; Edward N. Luttwak. "Doing counterterrorism right." Nikkei Asian Review. Published on 30 November 2015. https://asia.nikkei.com/Viewpoints-archive/Viewpoints/Doing-counterterrorism$\underline{\text { right?page }=1}$
} 
authorities, and the process of administrative deportations allows the expulsion of suspects in cases where there would otherwise be insufficient evidence for a criminal prosecution. From a counterterrorism perspective, this has proven to be effective for Italy. Other EU member states have had suspects exploit freedom of speech, allowing them to radicalize expansive networks, until there was sufficient evidence to warrant their arrest. ${ }^{204}$

On the other hand, these administrative deportations act as a deterrent for foreign citizens residing in Italy who may be susceptible to radicalization based on their personal networks and/or ideological views. Broad surveillance powers combined with the swift likelihood of deportation that can be warranted on the grounds of suspicion that an individual even supports terrorist activities (without necessarily being involved in a plot or network) can serve as reasons to prevent foreign citizens from engaging in suspicious behaviour. The threat of deportation can be especially convincing for individuals who were born and grew up in Italy but have not yet become naturalized citizens, and who may be returning to a country where they face even more strict penalties for engaging in terrorist activities (e.g. torture). ${ }^{205}$

This leads into the risks of administrative deportations. While there has not been resistance to Italian deportation laws within the country, Italy has received criticism from the European Court of Human Rights (ECtHR) regarding these extensively used administrative deportations because of civil liberty concerns. In one prominent case, Saadi v. Italy (2008), the ECtHR found that Italy's attempted expulsion of Tunisian-citizen Naasim Saadi was unprecedented and violated Article 3 of the European Convention on Human Rights (ECHR),

\footnotetext{
${ }^{204}$ Anjem Choudary is the infamous case applied to exemplify this scenario. He was the former spokesperson and leader for Islam4UK, a group that is best known for its conference, "the Magnificent 19", where 9/11 was praised, and for their vocal opposition of modernizing Islam. Choudary was well known for preaching on the streets of London, but because his speeches never openly instructed acts of terrorism, it took years for the British authorities to convict him. Source: Nick Chatrath, "Fighting the unbeliever: Anjem Choudary, Musharraf Hussain and pre-modern sources on sūra 9.29, abrogation and jihad," Islam and Christian-Muslim Relations 21 no.2, 2010: 112.

${ }^{205}$ Marone, Francesco. 2017. "The Use of Deportation in Counter-Terrorism: Insights from the Italian Case." International Centre for Counter-Terrorism - The Hague ; Luca Masera, "Il terrorismo e le politiche migratorie: sulle espulsioni dello straniero sospettato di terrorismo", 2016, 77.
} 
because Saadi would face a "real risk of torture, inhuman or degrading punishment or treatment" in his home country, therefore his deportation was blocked by the ECtHR ${ }^{206}$ Although this is a legitimate concern regarding Italy's expulsion program, most deportees are of Balkan origin (primarily from Kosovo and Albania), therefore there is nearly no risk of inhumane punishment. $^{207}$

Alternatively, Administrative deportations are also criticized for being more repressive than preventative. ${ }^{208}$ While some researchers argue that the measures hover in an ambiguous zone between "repressive" and "preventative", all of the literature seems to agree that deportations may be effective in the short-to-medium term, but it is unlikely that results will be produced in the long term. The primary concern is that the repressive nature of the measure will create a new generation of individuals who seek revenge against the Italian government for actions carried out on their parents or older siblings. This is already slowly becoming evident with those undergoing the ramifications of administrative deportations. In a more recent case, which was mentioned earlier in this section, Tunisian-national Hosni Hachemi Ben Hassen, a Muslim cleric, was expelled from southern Italy back to Tunis in July 2016 after undergoing active and aggressive surveillance for more than decade. In an interview with Politico, he declared that he is "angry with Italy" and that "[Italy] is dictatorial toward religious Muslims". Hassen has younger sons, who witnessed their father's arrest and deportation - these are the demographics that should be a cause of future concern.

\footnotetext{
${ }^{206}$ Corte Edu, Grande Camera, 28.2.2008, Saadi c. Italia, 37201/06. http://www.unionedirittiumani.it/wpcontent/uploads/2014/11/sent-cedu-saadi.pdf

${ }^{207}$ Marone. 2016. "Italy's Jihadists in the Syrian Civil War."

${ }^{208}$ Marone. 2016. "Italy's Jihadists in the Syrian Civil War." ; Luca Masera. September 2016. "Il terrorismo e le politiche migratorie: sulle espulsioni dello straniero sospettato di terrorismo." Questione Giustizia: Terrorismo internazionale. Politiche della sicurezza. Diritti fondamentali. http://www.questionegiustizia.it/speciale/pdf/QG-Speciale_2016-1.pdf\#page=77;

Paravicini. 2016. "From mafia to terror, the Italian way."
} 
Italy's extensive use of its administrative deportation powers is envied by other states that wish they could also expel suspicious individuals that could be fueling extremist networks within their territory. The expulsion measures have been producing effective results in Italy, particularly since its amendment in 2005, but it is difficult to gauge how long these outputs will be effective. The measures are both preventative and repressive in nature, and Italy has leveraged its experiences with organized crime networks to disrupt jihadist networks. Italy's effective results with deportations are also possible due to the limited population of second- and third-generation Muslim immigrants, along with the country's strict citizenship laws, thus creating the right conditions to have a group of foreign citizens they can monitor.

Merging Anti-Mafia Measures with Anti-Terrorism: Preventative and Deterrent Measures

It has been repeated that Italy's unique experiences with organized crime and political violence has molded their counterterrorism measures and efforts. Although the Years of Lead formulated Italy's approach to reintegrative shaming as a counterterrorism strategy, it is the state's long history with combatting organized crime that continues to play a role in the methods taken to combat domestic terrorism. Moreover, the mafias have also conducted lethal acts that can be considered terrorism, particularly during their climax in the early 1990s where they conducted bombings across Italian cities to demonstrate their national power and sway political influence. ${ }^{209}$ The state's criminalization of mafias since Italy's unification in 1861 has enabled the country to improve the effectiveness of its measures targeting violent, networked groups. ${ }^{210}$

Italy's anti-mafia measures were proven to be extremely effective since the early 1990 s and well into the 2000s. After the climax of the mafia groups and their 'terrorist' attacks in 1992

\footnotetext{
${ }^{209}$ Letizia Paoli. September 2007. "Mafia and Organized Crime in Italy: The Unacknowledged Success of Law Enforcement." West European Politics 30(4): 858.

${ }^{210}$ Paoli. 2007. "Mafia and Organized Crime in Italy." 856.
} 
and 1993, law enforcement measures were enhanced and the groups took severe hits to their networks and operations. The aggressive measures targeted the chiefs of the mafia pseudo-mafia families, which resulted in numerous further arrests across the criminal networks. ${ }^{211}$ Italian law enforcement's extensive experience with targeting networks has allowed for them to effectively pursue and dismantle jihadist networks, which comprise a fraction of the number of Mafiosi.

It seems it would be a natural extension for Italy to amalgamate their counterterrorism measures with their anti-mafia measures, particularly considering the success of law enforcement agencies and the influence anti-mafias legislation has had on counterterrorism legislation. In early 2015, a new set of urgent measures for countering terrorism were introduced after the January 2015 attacks in Paris, in the form of Legislative Decree No.7/2015, which included amendments that reformatted several anti-mafia policies and polities to include counterterrorism. Beyond provisions that directly address the merging of antiterrorism and anti-mafia measures, Italy's deeply engrained approaches and behaviours have seeped into their counterterrorism measures. There is little tolerance in Italian legislature for individuals who are even suspected of partaking in, or supporting, terrorist activities. This was particularly highlighted earlier in Italy's deportation policies, where even suspicions of terrorist activity can be applied to expedite a foreign citizen's deportation. Additionally, strengthened police surveillance powers and provisions regarding personal data have enabled law enforcement to conduct "preventative wiretapping". ${ }^{212}$ This has made Italy the only European country to explicitly legalize remote

\footnotetext{
${ }^{211}$ Ministero dell'Interno. 2005. Rapporto sullo stato della sicurezza in Italia 2005 (English: "Report on the State of Security in Italy 2005"). Rome: Ministero dell'Interno.

${ }^{212}$ LEGGE 17 aprile 2015, n. 43 Conversione in legge, con modificazioni, del decreto-legge 18 febbraio 2015, $n$. 7, recante misure urgenti per il contrasto del terrorismo, anche di matrice internazionale, nonche' proroga delle missioni internazionali delle Forze armate e di polizia, iniziative di cooperazione allo sviluppo e sostegno ai processi di ricostruzione e partecipazione alle iniziative delle Organizzazioni internazionali per il consolidamento dei processi di pace e di stabilizzazione (English: "LAW 17 April 2015, n. 43 Conversion into law, with modifications, of the decree-law of February 18, 2015, n. 7 on urgent measures to counter terrorism, including an international matrix, as well as the extension of the international missions and police missions, development co-operation initiatives and support for reconstruction processes and participation in the initiatives of international organizations for consolidation of peace and stabilization processes.”). (15G00060) (GU n.91 del 20-04-2015 )
} 
computer searches and conduct covert data collection, raising concerns about infringements on constitutional rights and civil liberties. ${ }^{213}$ In addition, Italy is the only European country that can use intercepted communications traffic as evidence in courts in order to obtain warrants and/or pursue convictions against suspected terrorists/Mafiosi. ${ }^{214}$ These concerns would not be the first time Italy's legislation was questioned regarding its balance of civil liberties and preventative measures for anti-mafia and anti-terrorism purposes, but objections have alleviated since the 2013, when leaks by Edward Snowden revealed sensitive surveillance programs that heightened peoples' awareness of privacy laws.

Italy's history and convergence of anti-mafia and antiterrorism measures provides them with a beneficial advantage in this wave of jihadist terrorism. To date, it is widely known that a large portion of European jihadist extremists, particularly those who have affiliated themselves with Daesh, have a history with criminal activities and many have previously been in prison on charges not related to terrorism. This phenomenon has been dubbed the crime-terror nexus, which addresses two independent, but correlated, factors contributing to the spread of jihadist extremism on the continent. The crime-terror nexus is not a new analytical model; it has been used for over a decade now to explain the relationship between organized crime and terrorism, but it has become more popular in terrorism literature in recent years following Daesh's ascension in $2014 .^{215}$ The crime-terror nexus may result in convergence between the two variables, but it is necessary to highlight that there is no evidence or appropriate research suggesting that there is collaboration in Italy between the mafia groups and jihadist groups, nor is

\footnotetext{
${ }^{213}$ Stefano Quintarelli. March 2015. "Update: Una Svista Rilevante Nel Provvedimento Antiterrorismo."

${ }^{214}$ Stephanie Kirchgaessner and Lorenzo Tondo. "Why has Italy been spared from ass terrorist attacks in recent years?" The Guardian. Published on 23 June 2017. https://www.theguardian.com/world/2017/jun/23/why-has-italy-been-spared-mass-terrorattacks-in-recent-years

${ }^{215}$ Tamara Makarenko. 2014. "Categorizing the crime-terror nexus in Europe," in Global Crime 15(3-4): 259-274.
} 
the country protected by the mafia from jihadist extremism, despite the proliferation of media stories speculating otherwise. $^{216}$

While Italy does have an external military role in counterterrorism (notably as members in the Global Coalition combatting Daesh in Syria and Iraq), their internal strategies are better equipped to tackle the threat internally. Notwithstanding the importance that the so-called Caliphate serves for Daesh affiliates, the European context requires addressing its jihadist phenomenon internally and relying on criminological and sociological perspectives to mitigate the proliferation of problem. This "criminal" component is necessary to acknowledge because Europe's new generation of jihadists may not necessarily care about the political objectives motivating senior Daesh leadership, rather they are already "radical" individuals that apply a violent interpretation of Islam as an excuse to justify their criminality and to seek forgiveness for their previous misdemeanors. ${ }^{217}$ Additionally, a small fraction of individuals are also drawn to extremist groups not because of political motivations, but because of the prospects of comradery, excitement, adventure, and glory. ${ }^{218}$ The "criminal" component should ultimately drive counterterrorism policy for other European countries, because the question becomes whether Europe is dealing with radical Islamists or Islamized radicals.

Italy has prioritized preventative measures for decades due to their battles with organized crime, and new adopted legislation and amendments reflect Italy's attempts to remain current with how technology is being used by criminal networks, whether that is for organizing plots, recruiting new members, or simply spreading propaganda.

\footnotetext{
${ }^{216}$ Leonardo Bianchi. "Spiacenti, la mafia non 'protegge' l'Italia dallo Stato Islamico," (English: "Sorry, the mafia is not 'protecting' Italy from the Islamic State") in Vice News Italia. Published on 20 November 2015.

https://news.vice.com/it/article/mafia-protegga-italia-da-stato-islamico

${ }^{217}$ In an interview with CTC Sentinel, Alain Grignard is a senior member of the counterterror unit in the Brussels Federal Police, described this new trend as "Islamicized radicals", who he typecasted as young Muslims from "inner-city" areas of western European countries who dabbled in petty crime and were part of street gangs (source: Paul Cruikshank, "A View from the CT Foxhole: An Interview with Alain Grignard, Brussels Federal Police," in CTC Sentinel 8 no.14 [August 2015]: 7-8).

${ }^{218}$ Randy Borum and Robert Fein, "The Psychology of Foreign Fighters," in Studies in Conflict \& Terrorism, 40 no.3 (2017): 252.
} 
Holistic Deterrent Approaches: Collaboration, Reintegration, and Prison Reforms

Although Italy prioritizes the prevention of terrorism in seemingly aggressive manners, the state has adopted unique approaches that distinguish them in Western counterterrorism efforts. These approaches can be described as alternative, or even "holistic", as they suggest policy implementation of tactics that are not conventional because they often involve a "grey zone" for terrorists. These holistic approaches are manifested in collaboration, negotiations, reintegration into society, and prison reforms to prevent the radicalization of convicts. ${ }^{219}$

It was mentioned earlier that during the fourth period of the Years of Lead, Italy provided suspected and convicted terrorists with the option of collaboration in return for shortened sentences and limited charges. This method has continued to be implemented against jihadist extremists, and it was included in Legislative Decree No.144/2005 for Urgent Measures to Counter International Terrorism, particularly regarding deportations. Italy uses incentives such as national residency permits for individuals who are suspected of being a threat to national security in exchange for information on their networks. The use of these incentives combined with the threat of deportation demonstrates Italy's exercise of deterrence theory and how it can be used to deter and prevent attacks in the country. Deterrents are meant to identify the interests and vulnerabilities of adversarial actors, and to exploit them in a way that ceases support, activities, and operations that are a threat to the state. ${ }^{220}$

\footnotetext{
${ }^{219}$ Ryan Shaffer, "Jihad and Counter-Jihad in Europe: Islamic Radicals, Right-Wing Extremists, and Counter-Terrorism Responses," Terrorism and Political Violence 28 no.2, 2016, 389 ; Peter R. Neumann, "Prisons and Terrorism: Radicalisation and De-Radicalisation in 15 Different Countries," A policy report published by the International Centre for the Study of Radicalisation and Political Violence (ICSR) in partnership with the National Consortium for the Study of Terrorism and Responses to Terrorism (START), 2010.

${ }^{220}$ Alex Wilner, Deterring Rational Fanatics, Philadelphia: University of Pennsylvania Press 2015, 187.
} 
Despite the rate of effectiveness of Italy's approach to deterrence and prevention through collaboration and deportation, collaboration itself is not a popular approach for protecting national security and countering terrorism. Collaboration, along with negotiations, are seen negatively amongst security researchers, policy makers, and counterterrorism practitioners. ${ }^{221}$ There is a perception that engaging with terrorists and terrorist organizations gives them more power than they deserve, thus enabling them to continue their activities rather than deterring them from carrying out their operations. Ransom payments often come to mind when negotiations are discussed because they are controversial and opinions differ among governments and the public. Terrorist organizations who kidnap foreigners will demand ransoms and use this as means to finance their activities, resulting in a debate whether a government should ensure the safety of their citizens and pay the ransom, or should governments deny their demands. By denying terrorist groups from their demands, the hope is that they deter the groups from kidnapping foreign citizens because it will not be a viable method for financing. ${ }^{222}$

Many EU states, including Italy, frequently pay ransoms to release hostages while actively denying these negotiations, thus inadvertently financing terrorist groups. ${ }^{223}$ Kidnapping for ransom has become one of the most crucial means of terrorist financing, and in particular, $\mathrm{Al}$ Qaeda has made a business out of European ransom payments and senior leadership has credited ransom payments for funding operations. ${ }^{224}$ It is a difficult decision for politicians to make, and even more difficult to determine whether it is more effective to pay or not pay the ransom.

\footnotetext{
221 Martin Hughes, "Terror and negotiation," Terrorism and Political Violence 2 no.1, 1990, 72-825, DOI: 10.1080/09546559008427051 ; Richard Clutterbuck, "Negotiating with terrorists," Terrorism and Political Violence 4 no.4, 1992, 263-287, DOI: 10.1080/09546559208427186 ; Carl Miller, "Is it Possible and Preferable to Negotiate with Terrorists?", Defence Studies 11 no.1, 2011, 145-185, DOI: 10.1080/14702436.2011.553109.

${ }^{222}$ Max Abrahms and Matthew S. Gottfried, "Does Terrorism Pay? An Empirical Analysis," Terrorism and Political Violence, 28 no.1, 2016.

${ }^{223}$ Rukmini Callimachi. "Paying ransoms, Europe bankrolls Al Qaeda terror.” The New York Times. Published 29 July 2014. https://www.nytimes.com/2014/07/30/world/africa/ransoming-citizens-europe-becomes-al-qaedas-patron.html? $\mathrm{r}=0$

224 -- "Al Qaeda letter on the importance of kidnapping revenue." The New York Times. Published on 29 July 2014.
} 
Paying ransoms is by no means an approach imposed by the Union, but most EU members do follow this route, while countries such as the US, Canada, and the UK refuse to pay ransoms; this has been a hardline American policy since former President Richard Nixon declared in 1973 that the US will not negotiate with terrorists. The premise at that time (and to this day for some governments) is that it is more effective to refuse paying ransoms, because if states yield to the terrorists demands, it will encourage further kidnappings. However, this has never proven to be effective or correlated; a RAND study in the 1970s found little correlation between the US's negotiating policy and the occurrence or absence of further kidnappings. Additionally, the study found that even when ransoms were not paid, terrorists derived benefits from kidnappings, including publicity, alarm, and throwing governments into crisis. ${ }^{225}$ Evidently it seems that if a terrorist group pursues kidnapping for ransom, they benefit whether or not the payments are made. Therefore, it is not necessarily more effective to pay ransoms, but it can contribute to preventing the execution of citizens.

A more effective means of engaging with terrorists is through collaboration, resulting in disrupted networks and plots while also preventing attacks and other activities. Italy has had successful output results once they instigated this measure in the fourth period of the Years of Lead. Collaboration involved providing incentives to deter the individual from continuing to partake in terrorist activities (notably providing means for reintegration) while also applying an understanding of the bureaucratic and organizational nature of terrorist organizations in order to infiltrate the networks and arrest enough members to have a significant negative impact on future plots. Italy continued with this method and has included it in its immigration legislation on the expulsion of foreign citizens; even if a foreign citizen is charged on the grounds of national

\footnotetext{
${ }^{225}$ Brian Michael Jenkins. "Why the US swaps prisoners but doesn’t pay ransoms.” RAND Blog. Published on 2 September 2014. https://www.rand.org/blog/2014/09/why-the-us-swaps-prisoners-but-doesnt-pay-ransom.html
} 
security and is sentenced to deportation, Italy provides the convicted foreigner with the option of collaborating with authorities in exchange for residency.

It was stated earlier that issues of discrimination and socio-economic disparities do not account for the primary reasons of radicalization among Italian extremists. This means that even if Italy ensures that it has granted the Muslim community an intensa, and they continue to design urban areas in ways that prevent ghettoizing immigrant communities, the results of reintegration will fundamentally depend on the attitudes of the Italian society. In a MTV Italia interview with the Moroccan-Italian extremist Anas el Abboubi (who became well-known for his role of forming Sharia4Belgium, a radical Salafist organization calling for Belgium's conversion into an Islamist state), he declared that he did love Italy, and he was proud of his dual identity, but he specifically attacked the concept of integration adopted by most Italians and described them as intolerant (the earlier referenced survey conducted by Pew on Italy's negative perception of Muslims can confirm this intolerance). ${ }^{226}$ Anecdotes such as el Abboubi's reflect the importance of engaging with individuals who are suspected or charged for jihadist extremism. Terrorism is a means of communication, and more often than not, groups and individuals who engage in terrorist activities (either actively or through passive/financial support) are vocal about their demands and their experiences that pushed them to their ideology. Italy's own historical experiences with reintegration programs have demonstrated their effectiveness in preventing resurges of political extremism (right- and left-wing extremist groups continue to exist in Italy, but they do not pose the same threat as they once did), therefore Italy should consider reimplementing reintegration programs based on reintegrative shaming theory.

Italy's reintegration programs in the late-1980s were preceded with the Legge 18 febbraio 1987, no.34 Misure a favore di chi si dissocia dal terrorism (English: "Law of 18 February 1987,

\footnotetext{
${ }^{226}$ Vidino. Il jihadismo autoctono in Italia, 62.
} 
no.34 Measures favouring those who have disassociated from terrorism"), establishing provisions substantially reducing sentences for some convictions on terrorism if the convicted individual cooperates with authorities and actively demonstrated their disaffiliation with their terrorist organization. ${ }^{227}$ Earlier legislation specifically differentiated between "disassociation" and "collaboration"; legally, disassociation involved fully confessing to all offences committed during a trial and declaring how the defendant intends on mitigating and/or preventing related offences in the future. These testimonies were the clearest representation of reintegrative shaming. ${ }^{228}$ In addition to these testimonials, even though many prisoners were eventually released, they were not discharged immediately. While they continued to serve the remainder of their sentence, they were also provided the opportunity to work outside of the prison in order to put their pasts behind them and move to a less restricted prison regime that also allowed them to begin to lay the foundations for life after release. The program's success was also demonstrated based on the fact that terrorists who were still at large surrendered themselves so that they could enter these disengagement and disassociation programs. ${ }^{229}$ This program resulted in the release of 269 convicted terrorists between February and May $1987 .{ }^{230}$

Italy is implementing reintegrative shaming theory in methods outside of a reintegration program: despite the lack of preventative and de-radicalization measures adopted in legislation between 2001 and 2016, Italy has moved forward with a couple of prison reforms to help prevent individuals currently incarcerated from adopting a jihadist ideology while also de-radicalizing

\footnotetext{
${ }^{227}$ Legge 18 febbraio 1987, no.34 Misure a favore di chi si dissocia dal terrorism (English: "Law of 18 February 1987, no.34 Measures favouring those who have disassociated from terrorism"). http://www.inventati.org/cope/wp/wpcontent/uploads/2015/12/56_legge_18_febbraio_1987_n_34.pdf

${ }^{228}$ Gazzetta ufficiale n 149 del 2 giugno 1982 (English: "Official Gazette no. 149 of 2 June 1982") referenced in "La dissociazione politica dal terrorismo" (English: "Political disassociation from terrorism") in Insorgenza. Published on 1 January 2009. https://insorgenze.net/2009/01/01/la-dissociazione-politica-dal-terrorismo/

${ }^{229}$ Andrew Silke. "Disengagement or Deradicalization: A Look at Prison Programs for Jailed Terrorists." Combating Terrorism Centre at West Point Publications. Published on 1 January 2011. https://ctc.usma.edu/posts/disengagement-or-deradicalization-alook-at-prison-programs-for-jailed-terrorists

${ }^{230}$ Jeremy Ginges. 1997. "Deterring the Terrorist: A Psychological Evaluation of Different Strategies for Deterring Terrorism." Page 172
} 
current extremists. The first reform is the counter-radicalization program funded by the Ministry of Justice Penitentiary Police, which provides de-radicalizing training to over 100 agents working for Italian prisoners where terrorists are held. The training focuses on recognizing signs of radicalization among prisoners and identifying high-risk inmates and separating them from other individuals who are vulnerable to radicalization. ${ }^{231} \mathrm{~A}$ more recent reform, which has been applauded by other European countries, was instilled in January 2017 after the Ministry of Interior announced that it will fund courses on the Italian constitution and the importance of the freedom of religion and speech for imams throughout the country. ${ }^{232}$ In addition, imams will be invited into Italian prisons to prevent Muslim inmates from straying and interpreting Islam in radical ways. $^{233}$

This adoption of prison reforms reflects appropriate progress for Italian efforts to prevent individual from radicalizing and partaking in terrorist activities. It also reflects a change in rhetoric regarding the radicalization within Italian prisons, because less than ten years ago Italian prison authorities stated that there is a ban against imams from outside the prison. ${ }^{234}$ At this time, there was also a vocal intent to ensure that the Italian prisons are not used to recruit or indoctrinate extremists, but it seems as though formal programs were developed only recently. As these programs are relatively new and are slowly being implemented, it is difficult to evaluate their performance and effectiveness, but a future study would benefit from the existence of these preventative programs.

\footnotetext{
${ }^{231}$ La radicalizzazione del terrorismo islamico: Elementi per uno studio del fenomeno di proselitismo in carcere. Qaderni ISSP (9). Istituto Superiore di Studi Penitenziari. June 2012.

${ }^{232}$ Ilaria Venturi. "La Costituzione spiegata agli imam, il primo corso a Ravenna," (English: "The Constitution will be taught to imams, the first course in Ravenna"). La Repubblica - Bologna. Published on 10 January 2017.

${ }^{233}$ Frances D’Emilio. "Italy invites imams into prisons to deter extremism.” Toronto Star. Published on 12 July 2017.

${ }^{234}$ Carl Björkman. "Salafi-Jihadi terrorism in Italy," in Understanding Violent Radicalization: Terrorist and Jihadist Movements in Europe, ed. Magnus Ranstorp, Routledge: 2010. 242.
} 


\section{E. CONCLUSIONS}

Italy has demonstrated their experience in understanding organizational behaviour and the desire of individuals to reintegrate in society through their methodological approaches in counterterrorism. Their historical experiences have enabled them to develop seemingly effective counterterrorism strategies, albeit many have fallen under either the PROTECT, PURSUE, or RESPOND pillars of the EU's Counterterrorism Strategy. Despite this, Italy has applied preventative approaches and logic in these measures as a result of their history with political terrorism. This thesis examined measures legislated between 2001 and 2016, therefore it did not take into account the developments the Italian government has made with developing and implementing counterterrorism measures that fall under the PREVENT pillar throughout 2017.

This thesis argues that the EU's counterterrorism measures are ineffective because the EU fails to apply preventative measures that are modeled after deterrence theory and the reintegrative shaming strategy. Italy's historic application of deterrence theory and the reintegrative shaming strategy allowed for the country to effectively combat the left-wing extremist groups during the Years of Lead, resulting in significant disintegration of the existence of these groups that severely impacted their networks and operations. These methods were more or less continued in Italy's approaches against jihadist extremism, notably in their collaboration with terrorists if they faced deportation. Italy has also applied preventative measures that are beyond the scope of countering violent extremism and preventing radicalization as they are based off of measures to combat organized crime in the country. These measures are more aggressive, such as legal deportation and surveillance of individuals suspected of terrorism, as they are meant for the Italian authorities to take action in situations that would otherwise require 
a formal judicial process. The premise of these measures is for the authorities to take pre-emptive action to protect national security.

Concerns about Italy's balance between preventative counterterrorism and civil liberties could constitute a separate research project, but it is important to note that Italy's approach to expanded powers has differed compared to other Western countries. Following large scale attacks, politicians pushed for expanded and drastic emergency powers for combatting terrorism, resulting in fast-tracked legislation that either is not deliberated in due process or it does not go through the formal legislative process. New terrorism legislation in Italy has gone through the standard parliamentary routes for amending laws, ensuring that new laws do not infringe on the rights of citizens. $^{235}$

Many of Italy's counterterrorism measures are not based on regulated EU standards, approaches, or strategy. Those that do follow EU legislation were transposed as required by mandatory provisions and primarily dictated the policies surrounding the prohibition of financing terrorism and the sanctioning of specific groups and individuals. Italy's unique counterterrorism measures have been developed as a result of their violent years in the second half of the $20^{\text {th }}$ century, due to violence instigated by both political terrorist organizations and organized criminal groups. The country's approach to jihadist extremist has yielded effective results if one considers the sole objective of counterterrorism to be just to prevent attacks. Beyond that, Italy also has not produced nearly as many foreign fighters as other EU countries, nor has it arrested as many suspects as countries like the UK, Germany, or France. While this could partially be attributed to Italy's counterterrorism measures, it should also be acknowledged that Italy's conditions have been different compared to other EU members. The Muslim diaspora is just

\footnotetext{
${ }^{235}$ Elisabeth Rosenthal. "Italy proposes new powers to counter terrorists." The New York Times. Published on 13 July 20014. http://www.nytimes.com/2005/07/13/world/europe/italy-proposes-new-powers-to-counter-terrorists.html? r=0
} 
beginning to produce second and third generations who are coming of age, the community itself is far more fragmented and diverse, Islam is not even officially recognized in Italy (making it difficult to receive state funding for religious and cultural centres, and therefore receiving funding from external actors), and the urban landscape of Italian cities has not allowed for the development of ghettoized communities. Italy's pre-emptive and preventative measures have likely played a role in mitigating the proliferation of jihadist cells and networks in the country, but it is not as a taxing on the country because there are available resources given the smaller population deemed a possible threat.

Analysis of the various European border policies is a viable separate research project, but the conclusion derived for this thesis is that there is a lack of policy harmonization on nearly all fronts pertaining to counterterrorism, other than measures preventing financing terrorist groups and activities. Failure to harmonize is producing different outputs for counterterrorism across the Union, possibly to Italy's benefit as they have been able to continue with their specific, integrated approaches derived from their history of political violence and organized crime. A single approach to counterterrorism is required in a Union that shares borders, allowing the free movement of individuals belonging to cells and networks within the EU. Additionally, the lack of a single intelligence agency allowing and ensuring that member states share counterterrorism intelligence is also hindering the Union's effectiveness in combatting terrorism across its member states. Beyond these measures focusing on the PROTECT and PURSUE pillars of the EU's Counterterrorism Strategy, it is also necessary that member states begin harmonizing preventative policies to a certain degree. Italy can contribute its experiences with preventative measures (that are not necessarily illustrated in the above analyses) to help the EU develop 
directives that would provide member states with achievable objectives that would fall under the PREVENT pillar

With Italy's younger Muslim population slowly coming of age, it is important for Italy to learn from the mistakes of other EU states. Socio-economic disparities and discrimination may not have been a primary factor of radicalization in in the last couple of decades, but Italy should be aware of how other countries went wrong. There is a large portion of the Italian population that does not view Muslims favourably, and this is something that needs to be addressed by the government. A bottom-up approach should be implemented that targets Italian citizens and addresses hostile behaviour in an effort to reverse it, because it is these negative attitudes that build a foundation for resentment.

The final chapter will build off from the conclusions of the European and Italian policy analysis by exploring the gaps in the EU's policy that could be mitigated by (a) applying the strengths of Italy's counterterrorism policy (resulting from Italy's application of deterrence theory), (b) building off from deterrent measures to develop effective preventative measures, and (c) by enforcing harmonized measures. 


\section{CHAPTER VI: CONCLUSION}

"6. Tyrannical toward himself, he must be tyrannical toward others. All the gentle and enervating sentiments of kinship, love, friendship, gratitude, and even honor, must be suppressed in him and give place to the cold and single-minded passion for revolution. For him, there exists only one pleasure, on consolation, one reward, one satisfaction - the success of the revolution.

Night and day he must have but one thought, one aim - merciless destruction. Striving coldbloodedly and indefatigably toward this end, he must be prepared to destroy himself and to destroy with his own hands everything that stands in the path of the revolution." - Sergey Nechayev

In a November 2017 BBC interview with the British ex-wife of an American Daesh leader, she made a statement saying that, "jihadists need to be heard, because if we don't know their arguments, and how poor those arguments are, we're not going to be able to discuss and refute them."236 This statement reiterates one of the main points being made throughout this thesis, namely that counterterrorism policies do not reflect a legitimate understanding of terrorism from any perspective, be it from a psychological, operational, or organizational level. Moreover, the measures fail to differentiate between ideologies, their subsets, and the various organizations that fight in the name of a certain ideology.

Following an examination of the literature and a policy analysis conducted on European and Italian counterterrorism measures, this thesis concludes by arguing that the EU's counterterrorism measures are ineffective because:

1. Member states have not harmonized their counterterrorism policies with the EU's policies. This is primarily evident in the EU's failure to establish a fully integrated internal security agency at the European level; and,

\footnotetext{
${ }^{236}$ Rickin Majithia and Colleen Hagerty. "How I Divorced the Islamic State." BBC News - World. Published on 27 November 2017. http://www.bbc.com/news/av/world-42116279/how-i-divorced-islamic- 
2. The EU's counterterrorism measures (a) fail to address the PREVENT pillar of the EU's counterterrorism Strategy and (b) the measures lack strategic guidance, in particular, this can be illustrated through deterrence theory.

The former was determined through the Italian case study, where it was found that Italy adopts counterterrorism measures that do not follow the EU's so-called norms for counterterrorism; thus, this will exemplify how the difference in measures is one factor to consider when examining the different results of counterterrorism. Additionally, an analysis of European intelligence sharing mechanism also demonstrated the fragmented nature of security institutions in the EU and how this is a hindrance for developing effective counterterrorism measures. The latter argument was demonstrated through a qualitative policy analysis illustrating four trends in the EU's counterterrorism framework: the EU's measures are reactionary and feed into the concept of the "Politics of Fear", in which the jihadist threat is highly securitized and therefore numerous measures are introduced after large-scale attacks; the EU fails to produce clear objectives based on the SMART model for goal setting, allowing them to continue developing broad and vague measures that do not combat terrorism effectively; a large majority of measures fall under the PURSUE pillar of the EU's Counterterrorism Strategy, along with a significant number falling under the PROTECT pillar, demonstrating that the EU primarily takes action to combat terrorism after attacks have taken place and after individuals have already affiliated themselves with terrorist organizations; and the themes identified in the EU's counterterrorism measures epitomizes that the EU will only take concrete action in policy fields it maintains competencies in (namely financial matters, such as economic sanctions, and border security).

This thesis set out with the aim of developing a framework for determining effectiveness of counterterrorism measures. Following the examination of measures, a concise framework was 
not developed; however, the attempted use of the SMART model led to a contribution to the literature because no previous studies evaluated the objectives of counterterrorism measures by taking a systematic approach such as the SMART model. Additionally, this thesis provides a case study using Italy, whose counterterrorism efforts have been scantily examined, particularly with regards to its approaches to combat jihadist extremism. Throughout this thesis' research, more literature was being published on the Italian model but none of the literature examined how Italy was performing in the theatre compared to the overall EU model.

The measures analyzed for this thesis were not used to provide a comparison of the Italian and European counterterrorism models and measures, but applying Italy as a case study was intended to drive two purposes. First, this thesis examined whether Italy adopts and implements measures derived from the EU's Counterterrorism Strategy, and if so, to what extent are these measures implemented into national legislation; and second, this thesis examined how Italy's counterterrorism model has diverged from the EU's standards in order to accomplish effective results, and whether these Italian measures can be leveraged by the EU and its member states to produce similar results. By assessing both the EU and Italian models, this thesis also offered suggestions to both actors on how they can learn from one another in order to develop more effective counterterrorism measures moving forward. The ultimate assumption is that the end goal of counterterrorism is to eradicate the threat posed to the affected state(s) - whether by disrupting terrorist organizations, dismantling their networks, or completing defeating them and eliminating their existence. The EU itself identifies that the Union's strategic commitment to counterterrorism is to "combat terrorism globally while respecting human rights". The EU's efforts in counterterrorism has demonstrated behaviour that contradicts this commitment because its measures suggest that the EU only takes action after large-scale attacks have already 
happened (based on the reactionary development of policies); additionally, if the EU wishes to "respect human rights" it should update this commitment to ensure it is more specific, particularly in the context of surveillance and privacy, which have been important issues to the public, predominantly since 2013. The EU's strategic commitment also specifies "globally", thus situating the counterterrorism theatre externally, which proves to be difficult for a Union that has difficulty establishing a single, coherent foreign, security, and defence policy and cannot yet act unilaterally in that realm. The EU should first focus on its internal security by creating a unified, single intelligence agency that enables cohesive sharing of intelligence.

The primary lesson that the EU and its member states can apply from the Italian case is the use of deterrence theory, and in particular the reintegrative shaming strategy, for developing measures that assist individuals in disengaging and disassociating with extremist ideologies and organizations. The Italians applied this strategy in the late 1980s, following nearly two decades of violence perpetuated by far-right and then far-left terrorist organizations. It resulted in establishing provisions substantially reducing sentences for some convictions on terrorism if the convicted individual cooperates with authorities and actively demonstrated their disaffiliation with their terrorist organization. ${ }^{237}$ Those who were convicted had to demonstrate their disassociation by fully confessing to all offences committed during a trial and declaring how the defendant intends on mitigating and/or preventing related offences in the future. In addition to these testimonials, even though many prisoners were eventually released, they were not discharged immediately. While they continued to serve the remainder of their sentence, they were also provided the opportunity to work outside of the prison in order to put their pasts behind them and move to a less restricted prison regime that also allowed them to begin to lay

\footnotetext{
${ }^{237}$ Legge 18 febbraio 1987, no.34 Misure a favore di chi si dissocia dal terrorism (English: "Law of 18 February 1987, no.34 Measures favouring those who have disassociated from terrorism"). http://www.inventati.org/cope/wp/wpcontent/uploads/2015/12/56 legge 18 febbraio 1987 n 34.pdf
} 
the foundations for life after release. The program's success was also demonstrated based on the fact that terrorists who were still at large surrendered themselves so that they could enter these disengagement and disassociation programs.

After years of failed measures based on emergency laws, Italy demonstrated an understanding of terrorism from a psychological level and from an organizational level. The state recognized that the organizations were waning and tackled it by addressing weak nodes in the network, allowing for further arrests. Italy's experience dealing with organized crime and networks proved to be fundamental to the country's approach to counterterrorism during the Years of Lead, and once again in recent years as the country aims to combat jihadist extremism. Italy has also taken preventative measures to ensure that attacks do not get carried out by permitting the deportation of individuals suspected to be a threat to national security, in addition to enabling law enforcement to carry out surveillance on suspects. While there is room to debate on these measures and how they balance protecting national security while protecting civil liberties, it does demonstrate that Italy is willing to act in preventative ways to combat terrorism before large-scale attacks have occurred.

To date, Italy's success could be attributed to both its counterterrorism measures, but also the unique circumstances of its history and demographics. As mentioned, Italy's historical experience allowed for the country to develop its counterterrorism measures and merge it alongside anti-mafia efforts. The state displays a lack of tolerance for security threats and is prepared to act to prevent and deter attacks. Italy's demographics and its relationship with its Muslim community have also set the country apart in terms of countering jihadist extremism. The majority of its Muslim population live in the northern regions, namely in Lombardy, and they are in urban areas. Additionally, the communities are fragmented and there are no "ghettos" 
in the same way that is witnessed in Paris or Brussels. This means that socio-economic reasons are not necessarily the issue for radicalization in Italy, as it is in other European countries. However, it is well known that Italy experiences economic trouble, particularly in the south, and this has the potential to escalade and impact its Muslim citizens. Italy can learn from other countries in this case, and work to examine their urban development to ensure that communities are not self-segregating themselves and to prevent ghettoization of certain ethnic groups.

The EU and its member states should strongly consider harmonizing their approaches and developing approaches that are not reactionary as a result of large-scale attacks. The EU's measures hardly reflect an effort to prevent terrorism and radicalization, nor do they reflect an understanding of how terrorists recruit, operate, and behave. The bulk of this thesis is oriented toward arguing for further policy harmonization within the EU if the Union wants to produce more effective, and possibly consistent, results across its member states.

\section{LIMITATIONS}

This thesis acknowledges that there are several gaps that present themselves in the research conducted, but also in the literature as a whole. Six gaps were identified in this research:

1. A single-case study within the EU was examined (Italy), whereas this study would have benefited from examining multiple case studies. This does pose difficulties as well because for each case study, the counterterrorism measures would have to be examined in relation to the member state's experiences with extremism and terrorism, combined with their relationship with Muslim diasporas. Another hindrance to this is the language barrier; not all member states publish all of their national legislations in 
English, therefore the study would have to ensure it has enough researchers to evaluate legislation in various languages.

2. The measures examined reflected only a subset of counterterrorism legislation for both the EU and Italy. The requirement was that the word "terrorism" or "terrorismo" was present in the title of the legislation, thus eliminating a large subset of measures that fell under the counterterrorism umbrella. Even by including these umbrella measures, the problem would be evaluating where these measures are effective for the purposes of counterterrorism specifically.

3. Due to the limited examination of only 139 of the EU's counterterrorism measures that are deemed to be binding (hard law), plenty of recommendations, proposals, action plans, and strategies were omitted. It would have been interesting to note how many of these non-binding measures are adopted and implemented by member states.

4. Although this thesis makes an argument that the lack of measures falling under the PREVENT pillar results in ineffective counterterrorism efforts, research that closely examines measures falling under only one of the pillars would also be beneficial in order to provide a better analysis of the gaps in legislation.

5. The researcher for this thesis recognizes and acknowledges the subjectivity that plays a role in the qualitative policy analyses. Although the methodology was outlined to provide the audience with information on the analyses, along with an approach to limit selection biased, the policies were categorized carefully to reflect the intentions of the EU. Research based on quantitative data would allow for better replication for future studies, but quantitative data would not accurately reflect the impact for 
counterterrorism measures that aim to disengage and disassociate individuals who are radicalized or susceptible to radicalization.

6. The aforementioned point leads into the final point - this thesis pushes for further development of policies under the PREVENT pillar, but under a formal effectiveness assessment, determining the effectiveness of such policies would be difficult. If measures are developed that take into account the sociological and psychological components of terrorism, then an assessment to evaluate material effectiveness would be required.

7. There are limits associated with policy harmonization at the EU level as well, and these limitations are based on the EU's policy competencies, particularly as they pertain to security policy and law enforcement. The EU has not achieved full political integration, yet its counterterrorism measures, and particularly its Counterterrorism Strategy, are overreaching and attempt to accomplish objectives that the EU does not have complete control over. Either the EU needs to reel back their aims and objectives to focus on areas where they can produce tangible results (primarily cutting the flow of money to terrorist organizations and measures protecting external borders), or the EU begins to move forward with deeper political integration, allowing them to accomplish further harmonization of policies and institutions. The EU's lack of internal borders allows for individuals engaging in terrorist activities to freely move between EU member states, evading law enforcement and intelligence agencies. Deeper political integration vis-à-vis a single intelligence agency would allow states to prevent this evasion. 
Beyond the limitations identified solely for the purpose of this research, there are limitations in the field of terrorism studies that hinder its progress. The literature review has already identified that the lack of studies focusing on effectiveness has been acknowledged by several researchers, but the gaps are never filled with an adequate framework that can be replicated. Determining effectiveness also requires "knowing the enemy" in order to combat terrorism; this thesis already underlined that the EU fails to demonstrate an understanding of how terrorists think, behave, and operate, but this implication stretches across the field of research. The issue is that the field of terrorism studies does not often engage in field work or conduct ethnographic research. Interviews that are conducted with former or even current members of terrorist organizations are often derived from media sources and their foreign correspondents. The role of ethics committees in academia likely plays a role in how closely a researcher can engage with terrorists legally and safely. In addition, the researcher could also experience ramifications with official government authorities for knowingly engaging with terrorists (particularly over a long period of time). Official authorities may also prevent or limit access to prisons holding individuals convicted on terrorism offences. Another limitation of the field is that terrorism studies should be approached from an interdisciplinary perspective, yet this is hardly ever the case. This thesis resulted in cross the disciplines of European studies, political science, and criminology, along with some psychology an sociology in order produce conclusions on the EU's counterterrorism efforts. In most terrorism research, the disciplines are often limited and approached solely from one of the aforementioned fields. Future studies should engage researchers, who specialize in various fields, to work together in order to bring their different mindsets and expertise to the table to contribute to better research; this is also applicable for counterterrorism officials. This leads into the subsequent limitation that this paper would like to acknowledge: the lack of access 
to classified materials regarding counterterrorism efforts and their effectiveness makes it extremely difficult to produce results that accurately depict the landscape of counterterrorism. It would bode well for the field to engage academics and practioners in order to develop better policy.

A final limitation, which is connected to one of the premises of this paper, is that there is an unwillingness (particularly from politicians) to acknowledge the rationality of terrorism, and to address the terrorist's justifications for their actions. It is uncomfortable to conclude that maybe terrorists are not "crazy" and that they do have their own logical underpinnings to validate their behaviour. The securitization and politicization of terrorism is doing a disservice to countries and their counterterrorism efforts. The beginning of each chapter of this thesis opened with a part from "The Duties of the Revolutionary Toward Himself" within the Revolutionary Catechism, written by Russian anarchist Sergey Nechayev. His manifesto was published in 1876, but a close reading of his work provides an insight to the extremist movements that followed, because each component of the Catechism is also relevant to jihadist extremists. The final part of the "The Duties of the Revolutionary Toward Himself" demonstrates the reckoning derived the logic of extremists:

"7. The nature of the true revolutionary excludes all sentimentality, romanticism, infatuation, and exaltation. All private hatred and revenge must also be excluded. Revolutionary passion, practiced at every moment of the day until it becomes a habit, is to be employed with cold calculation. At all times, and in all places, the revolutionary must obey not his personal impulses, but only those which serve the cause of the revolution." - Sergey Nechayev 
1. Abrahams, Max, Nicholas Beauchamp, and Joseph Mroszczy. 2017. "What Terrorist Leaders Want: A Content Analysis of Terrorist Propaganda Videos," in Studies in Conflict and Terrorism 40:11 (899-916). https://doi.org/10.1080/1057610X.2016.1248666

2. Abrahms, Max and Matthew S. Gottfried. 2016. "Does Terrorism Pay? An Empirical Analysis," in Terrorism and Political Violence, 28:1 (72-89): DOI: 10.1080/09546553.2013.879057.

3. Alexander, Yonah. Counterterrorism Strategies: Successes and Failures of Six Nations. Nebraska: Potomac Books 2006.

4. Allievi, S. "Islam Italiano e Società Nazionale," (English: "Italian Islam and Nationalist Societies") in Islam in Europa/Islam in Italia: Tra Diritto e Società (English: "Islam in Europe/Islam in Italy: Between Law and Society") ed. A. Ferrari. Bologna: il Mulino, 2008.

5. Aquilla, John and David Ronfeldt. 2007. "Networks and Netwars The Future of Terror, Crime, and Militancy." RAND Corporation Publications. http://www.rand.org/pubs/monograph_reports/MR1382.html

6. Austin, R.C. 2007. "The New Constitutionalism, Terrorism, and Torture," in Current Legal Problems 60:1 (79-120). https://www.researchgate.net/publication/275928606_The_New_Constitutionalism_Terro rism_and_Torture

7. Avey, Paul and Michael Desch. "What Do Policy Makers Want from Academics?" The Washington Post. Published on 25 September 2009. https:/www.washingtonpost.com/news/monkey-cage/wp/2013/09/25/what-dopolicymakers-want-from-academics/;

8. Avey, Paul C. et al. "The Beltway vs. The Ivory Tower." Foreign Policy. Published on 3 January 2012. http://foreignpolicy.com/2012/01/03/the-beltway-vs-the-ivory-tower/;

9. Baudrillard, Jean. "L’espirit du terrorisme” (English: "Spirit of Terrorism"). Le Monde. Published on 3 November 2001. https://monoskop.org/images/e/e2/Baudrillard_Jean_Lo_spirito_del_terrorismo_2002.pdf

10. Bianchi, Leonardo. "Spiacenti, la mafia non 'protegge' 1'Italia dallo Stato Islamico," (English: "Sorry, the mafia is not "protecting' Italy from the Islamic State") in Vice News Italia. Published on 20 November 2015. https://news.vice.com/it/article/mafia-proteggaitalia-da-stato-islamico 
11. Bjelopera, Jerome P. "American Jihadist Terrorism: Combatting a Complex Threat." Congressional Research Services: Prepared for Members and Committees of Congress. Published 23 January 2013. https://fas.org/sgp/crs/terror/R41416.pdf

12. Bjørgo, Tore. 2016. "Counter-terrorism as Crime Prevention: A Holistic Approach," in Behavioural Sciences of Terrorism and Political Aggression 8:1.

13. Björkman, Carl. "Salafi-Jihadi terrorism in Italy," in Understanding Violent Radicalization: Terrorist and Jihadist Movements in Europe, ed. Magnus Ranstorp, United Kingdom: Routledge 2010.

14. Blitz, James. "Hard questions for Belgium's security services.” Financial Times. Published on 23 March 2016. http://www.ft.com/cms/s/0/ba92eb42-f101-11e5-aff519b4e253664a.html\#axzz47CAzmCCq

15. Bocconi, Armando. "Ipotesi sulle cause e gli obiettivi del terrorismo cosiddetto islamico: le possibili soluzioni" (English: "Hypotheses on the causes and objectives of the so-called Islamic terrorism: the possible solutions"). ASPO Italia. Published in November 2004. http://www.aspoitalia.it/documenti/boccone/terrorismo.html

16. Borum, Randy and Robert Fein. 2017. "The Psychology of Foreign Fighters," in Studies in Conflict \& Terrorism, 40:3 (248-266): DOI: 10.1080/1057610X.2016.1188535

17. Botelho, Greg. "Salah Abdeslam, Paris terror suspect, captured; four others arrested." CNN News. Published on 18 March 2016. http://www.cnn.com/2016/03/18/world/parisattack-salah-abdeslam-fingerprints-capture/

18. Boutin, Bérénice. 2016. "Administrative Measures against Foreign Fighters: In Search of Limits and Safeguards." International Centre for Counter-Terrorism - The Hague. https://icct.nl/wp-content/uploads/2016/12/ICCT-Boutin-Administrative-MeasuresDecember2016-1.pdf

19. Braithwaite, John. Crime, Shame, and Reintegration. Melbourne: Cambridge UP 1989.

20. Bunyan, Tony. "Trevi, Europol and the European State." State-watching the New Europe, 1993. http://www.statewatch.org/news/handbook-trevi.pdf

21. Bures, Oldrich. 2006. "EU Counterterrorism Policy: A Paper Tiger?” in Terrorism and Political Violence 18:1 (57-78): https://doi.org/10.1080/09546550500174905

22. Bures, Oldrich. EU Counterterrorism Policy: A Paper Tiger? Surrey, UK: Ashgate Publishing Ltd. 2011.

23. Byman, Daniel L. "Comparing Al Qaeda and ISIS: Different goals, different targets." Brookings Institution. Published on 29 April 2015. https://www.brookings.edu/testimonies/comparing-al-qaeda-and-isis-different-goals- 


\section{different-targets/}

24. Callimachi, Rukmini. "Paying ransoms, Europe bankrolls Al Qaeda terror." The New York Times. Published 29 July 2014.

https://www.nytimes.com/2014/07/30/world/africa/ransoming-citizens-europe-becomesal-qaedas-patron.html?_r=0

25. Capone, Luciano. "Papa e Piketty sbagliano: il terrorismo non è figlio della povertà" (English: "The Pope and Piketty are wrong: Terrorism is not the result of poverty"). $\mathrm{Sa}$ Natzione. Published on 27 November 2015. http://www.sanatzione.eu/wpcontent/archivio_media/uploads/2015/12/URN-Sardinnya-Lopinione-Su-terrorismo-epovert $\% \mathrm{C} 3 \% \mathrm{~A} 0 . \mathrm{pdf}$;

26. Carlo Pisacane. La Rivoluzione (English: "The Revolution"). Italy, 1857. Accessed online 5 June 2017: http://www.bibliotecamarxista.org/pisacane\%20carlo/Carlo_Pisacane_La_Rivoluzione.pdf

27. Casuscelli, G. "La rappresentanza e l'intesa" (English: "Representation and the Agreement") in Islam in Europa/Islam in Italia: Tra Diritto e Società (English: "Islam in Europe/Islam in Italy: Between Law and Society") ed. A. Ferrari. Bologna: il Mulino, 2008.

28. Chatrath, Nick. 2010. "Fighting the unbeliever: Anjem Choudary, Musharraf Hussain and pre-modern sources on sūra 9.29, abrogation and jihad," in Islam and Christian-Muslim Relations 21:2 (111-126): DOI: 10.1080/09596411003687852

29. Chowdhury, Arjun and Scott Fitzsimmon. 2013. "Effective but Inefficient: Understanding the Costs of Counterterrorism," in Critical Studies on Terrorism 6:3 (447456). https://doi.org/10.1080/17539153.2013.836307

30. Corte Edu, Grande Camera, 28.2.2008, Saadi c. Italia, 37201/06. (English: "Saadi v Italy"). http://www.unionedirittiumani.it/wp-content/uploads/2014/11/sent-cedu-saadi.pdf

31. Cronin, Audrey Kurth. "Why Drones Fail: When Tactics Drive Strategy." Foreign Affairs. Published in July/August 2013 issue. https://www.foreignaffairs.com/articles/somalia/2013-06-11/why-drones-fail

32. Cruikshank, Paul. 2015. "A View from the CT Foxhole: An Interview with Alain Grignard, Brussels Federal Police," in CTC Sentinel 8:14 (7-10): https://ctc.usma.edu/wpcontent/uploads/2015/08/CTCSentinel-Vol8Issue814.pdf

33. D'Emilio, Frances. "Italy invites imams into prisons to deter extremism." Toronto Star. Published on 12 July 2017. https://www.thestar.com/news/world/2017/07/12/italyinvites-imams-into-prisons-to-deter-extremism.html 
34. De Graaf, Beatrice. Evaluating Counterterrorism Performance. New York, New York: Routledge 2013.

35. De Londras, Fiona. 2016. "The Impact, Legitimacy, and Effectiveness of EU CounterTerrorism." SECILE Consortium Publication. https://fdelondras.files.wordpress.com/2016/01/secile-d5-3.pdf

36. DeLutiis, G. Storia dei servizi segreti (English: "History of the Secret Service.”). Rome: Editori Riuniti, 1984.

37. Della Porta, Donatella. "Institutional Responses to Terrorism: The Italian Case," in Terrorism and Political Violence. 4:4.

38. Enders, Walter and Paan Jindapon. 2010. "Network Externalities and the Structure of Terror Networks," in The Journal of Conflict Resolution 54:2 (262-280).

39. Erlenbusch, Verena. 2015. "Terrorism and revolutionary violence: the emergence of terrorism in the French Revolution," in Critical Studies on Terrorism 8:2 (193-210): DOI: $10.1080 / 17539153.2015 .1049842$

40. European External Action Services. "Global Strategy to steer EU external action in an increasingly connected, contested and complex world." Published on 30 June 2015. Accessed on 13 February 2016. http://www.eeas.europa.eu/top_stories/2015/150627_eu_global_strategy_en.htm

41. European Union. 2001. Common Position 2001/931/CFSP on the application of specific measures to combat terrorism.

42. European Union. 2001. Council Regulation (EC) No 2580/2001 on specific restrictive measures directed against certain persons and entities with a view to combating terrorism.

43. European Union. 2001. "Council Decision of 22 January 2001 Setting up the Political and Security Committee (2007/78/CFSP)," in Official Journal of the European Communities, 27:1. http://eur-lex.europa.eu/legalcontent/EN/TXT/PDF/?uri=CELEX:32001D0078\&from=EN

44. European Union. 2002. Council Framework Decision of 13 June 2002 on combating terrorism. http://eur-lex.europa.eu/legal-content/IT/TXT/?uri=CELEX:32002F0475

45. European Union. 2005. Council of the European Union. European Union Counterterrorism Strategy. Council Document 14781/1/05. The Strategy was revised in November 2008. Council Document 15175/08. http://register.consilium.europa.eu/doc/srv?l=EN\&f=ST\%2015893\%202010\%20REV\%2 01 
46. European Union. 2011. Decision 2011/872/CFSP updating the list of persons, groups and entities subject to Articles 2, 3 and 4 of Common Position 2001/931/CFSP on the application of specific measures to combat terrorism.

47. European Union. 2011. Implementing Regulation (EU) No 1375/2011 implementing Article 2(3) of Regulation (EC) No 2580/2001 on specific restrictive measures directed against certain persons and entities with a view to combating terrorism.

48. European Union. 2015. Council Decision (EU) 2015/1914 of 18 September 2015 on the signing, on behalf of the European Union, of the Additional Protocol to the Council of Europe Convention on the Prevention of Terrorism (CETS No 196).

49. European Union. 2015. European Parliament Resolution of 25 November 2015 on the Prevention of Radicalization and Recruitment of European Citizens by Terrorist Organizations. http://www.europarl.europa.eu/sides/getDoc.do?pubRef=$\% 2 \mathrm{f} \% 2 \mathrm{fEP} \% 2 \mathrm{f} \% 2 \mathrm{fTEXT} \% 2 \mathrm{bTA} \% 2 \mathrm{bP} 8-\mathrm{TA}-2015$ 0410\%2b0\%2bDOC $\% 2 \mathrm{bXML} \% 2 \mathrm{bV} 0 \% 2 \mathrm{f} \% 2 \mathrm{fIT} \&$ language $=\mathrm{IT}$

50. Europol. 2017 Terrorism Situation and Trend Report. https://www.europol.europa.eu/activities-services/main-reports/eu-terrorism-situationand-trend-report

51. Europol. 2016 Terrorism Situation and Trend Report. https://www.europol.europa.eu/activities-services/main-reports/european-unionterrorism-situation-and-trend-report-te-sat-2016

52. Ganor, Boaz. 2002. "Defining Terrorism: Is One Man's Terrorist another Man's Freedom Fighter?" in Police Practice and Research 3:4. DOI: 10.1080/1561426022000032060

53. Ginges, Jeremy. 1997. "Deterring the Terrorist: A Psychological Evaluation of Different Strategies for Deterring Terrorism" in Terrorism and Political Violence 9:1 (170-185). https://doi.org/10.1080/09546559708427394

54. Gritti, R. and M. Allam. Islam, Italia: Chi sono e cosa pensano i musulmani che vivono tra noi. (English: "Islam, Italy: Who are they and what do Italians think of the Muslims that live among us?") Milan: Guerini e Associati, 2001.

55. Haas, Ernst B. The Uniting of Europe: Political, Social, and Economic Forces, 19501957 (3rd ed.). Notre Dame, Indiana: University of Notre Dame Press 1958 (2004 ed.).

56. Habeck, Mary. "What does Al Qaeda want?” Foreign Policy. Published on 6 March 2012. http://foreignpolicy.com/2012/03/06/what-does-al-qaeda-want/

57. Hackett, Conrad. "5 Facts about the Muslim Population in Europe." Pew Research Center. Published on 19 July 2016. http://www.pewresearch.org/fact-tank/2016/07/19/5- 
facts-about-the-muslim-population-in-europe/

58. Hamilton, Lee. 2007. "Chapter 3: Terrorist Organization Models" in A Military Guide to Terrorism in the Twenty-First Century.

http://www.au.af.mil/au/awc/awcgate/army/guidterr/ch03.pdf

59. Hamouda, Yossra. 2017. "When Subcultures Turn Into Ghettos: The Conceptual Ghetto and Oppression," in Sociology and Anthropology 5:8 (577-583): http://www.hrpub.org/download/20170730/SA1-19609782.pdf

60. Heger, Lindsay, Danielle Jung, and Wendy H. Wong. 2012. "Organizing for Resistance: How Group Structure Impacts the Character of Violence," in Terrorism and Political Violence 24:5 (743-768).

61. Jenkins, Brian Michael. "Why the US swaps prisoners but doesn't pay ransoms." RAND Blog. Published on 2 September 2014. https://www.rand.org/blog/2014/09/why-the-usswaps-prisoners-but-doesnt-pay-ransom.html

62. Jentleson, Bruce W. and Christopher A. Whytock. 2006. "Who 'Won' Libya? The ForceDiplomacy Debate and Its Implications for Theory and Policy," in International Security 30:3 (47-86): https://doi.org/10.1162/isec.2005.30.3.47

63. Jones, Seth G. and Martin C. Libicki. 2008. "How Terrorist Groups End: Lessons for Countering al Qa'ida." Rand Corporation Publications. http://www.rand.org/pubs/monographs/MG741-1.html

64. Jones, M., and K. Diment. "The CAQDA Paradox: A Divergence between Research Method and Analytical Tool." Paper presented at the 2nd International Workshop on Computer-Aided Qualitative Research, 82-86. Utrecht, The Netherlands: Merlien Institute. Published in June 2010.

65. Kaplan, Jeffrey. Terrorist Groups and the New Tribalisms: Terrorism's Fifth Wave. New York: Routledge 2012.

66. Keeney, Gregory L. and Detlof von Winterfeldt. "Identifying and Structuring the Objectives of Terrorism." National Center for Risk and Economic Analysis of Terrorism Events. Published in August 2009.

https://research.create.usc.edu/cgi/viewcontent.cgi?referer=https://duckduckgo.com/\&htt psredir $=1 \&$ article $=1142 \&$ context $=$ nonpublished_reports

67. Kirchgaessner, Stephanie and Lorenzo Tondo. "Why has Italy been spared from ass terrorist attacks in recent years?" The Guardian. Published on 23 June 2017. https://www.theguardian.com/world/2017/jun/23/why-has-italy-been-spared-mass-terrorattacks-in-recent-years 
68. Kohlmann, Evan. Al-Qaida's Jihad in Europe: The Afghan-Bosnian Network. New York, NY: Berg

69. Lubeck, Paul. "The Challenge of Islamic Networks and Citizenship Claims: Europe's Painful Adjustment to Globalization," in Muslim Europe or Euro-Islam, edited by Nezar AlSayyad and Manuel Castell. New York: Lexington Books 2002.

70. McQuaid, Julia, Jonathan Schroden, Pamela G. Faber, P. Kathleen Hammerberg, Alexander Powell, Zack Gold, David Knoll, and William Rosenau. Independent Assessment of U.S. Government Efforts against AlQaeda. The CNA Corporation. Published in October 2017. https://www.cna.org/cna_files/pdf/DRM-2017-U-0157102Rev.pdf

71. Morris, Harvey. “Europe's Cities: Gentrification or Ghettoization?” The New York Times. Published on 21 August 2012.

72. Momigliano, Anna. "In Italy, Islam doesn't officially exist. Here's what Muslims must accept to change that." The Washington Post. Published on 8 February 2017. https://www.washingtonpost.com/news/worldviews/wp/2017/02/08/in-italy-islam-doesntofficially-exist-heres-what-muslims-must-accept-to-changethat $/$ utm term $=.5 \mathrm{c} 83668 \mathrm{a} 850 \mathrm{f}$

73. Muro, Diego. "Counter-terrorist Strategies in Western Europe: A Comparative Analysis of Germany, Italy, Spain and the UK." Working paper for the European University Institute in Florence, Italy. Max Weber Programme. June 2016.

74. Nechayev, Sergey. Catechism of a Revolutionary. Russia, 1871. Accessed on 4 June 2017. https://www.marxists.org/subject/anarchism/nechayev/catechism.htm

75. Nesser, Petter and Anne Stenersen. "The Modus Operandi of Jihadist Terrorists in Europe," in Perspectives on Terrorism 8:6 (2014). http://www.terrorismanalysts.com/pt/index.php/pot/article/view/388/html

76. Neumann, Peter R. "Prisons and Terrorism: Radicalisation and De-Radicalisation in 15 Different Countries." A policy report published by the International Centre for the Study of Radicalisation and Political Violence (ICSR) in partnership with the National Consortium for the Study of Terrorism and Responses to Terrorism (START). Published in 2010. http://icsr.info/wp-

content/uploads/2012/10/1277699166PrisonsandTerrorismRadicalisationandDeradicalisat ionin15Countries.pdf

77. Neumann, Peter R. "Foreign fighter total in Syria/Iraq now exceeds 20,000; surpasses Afghanistan conflict in the 1980s." International Centre for The Study of Radicalisation And Political Violence. Published on 26 January 2015. http://icsr.info/2015/01/foreignfighter-total-syriairaq-now-exceeds-20000-surpasses-afghanistan-conflict-1980s/ 
78. Neumann, Peter R. Radicalized: New Jihadists and the Threat to the West. London: I.B. Tauris 2016.

79. Nomikos, John M. "European Union Intelligence Agency: A Necessary Institution for a Common Intelligence Policy?" in Contemporary Issues and Debates in EU Policy: The European Union and International Relations, ed. Vassiliki N. Koutrakou. Manchester, UK: Manchester University Press 2004.

80. Norheim-Martinsen, Martin and Jacob Aasland Ravndal. 2011. "Towards IntelligenceDriven Peace Operations? The Evolution of UN and EU Intelligence Structures," in International Peacekeeping 18:4. DOI:10.1080/13533312.2011.588391

81. O’Brien, Chris. "Why Academics Should Learn How to Influence Government Policy." The Guardian. Published on 7 June 2011. https://www.theguardian.com/highereducation-network/blog/2011/jun/07/academics-learn-influence-government-policy

82. O'Brien, Lauren. "The Evolution of Terrorism Since 9/11," in Law Enforcement Bulletin - Federal Bureau of Investigations. Published on 1 September 2011.

https://leb.fbi.gov/articles/featured-articles/the-evolution-of-terrorism-since-911

83. O'Neill, Bard E. Insurgency and Terrorism: Inside Modern Revolutionary Warfare. Washington, DC: Brassey’s Inc. 1990.

84. Pacini, Andrea. 2001. I Musulmani in Italia. (English: "Muslims in Italy"). University of Padova, Political Science Faculty, organized by GRIM, Research Group on Islam and Modernization. http://www.cestim.it/argomenti/02islam/02islam-relazione-pacini.pdf

85. Paoli, Letizia. 2007. "Mafia and Organized Crime in Italy: The Unacknowledged Success of Law Enforcement," in West European Politics 30:4 (854-880): https://doi.org/10.1080/01402380701500330

86. Paravicini, Giulia. "Busted jihadist network plotted to snatch diplomats." Politico. Published on 12 November 2015. http://www.politico.eu/article/europe-police-dismantlemajor-jihadist-network-krekar/

87. Paravicini, Giulia. "From mafia to terror, the Italian way." Politico Europe. Published on 3 November 2016. https://www.politico.eu/article/operation-expulsion-italyscontroversial-counterterrorism-strategy-tunisian-imam-civil-liberties/

88. Pargeter, Alison. The New Frontiers of Jihad: Radical Islam in Europe. Philadelphia, Pennsylvania: University of Pennsylvania Press 2009.

89. Penkenth, Anne. "Brussels Jewish Museum shooting: suspect with Islamist links arrested." The Guardian. Published on 1 June 2014. http://www.theguardian.com/world/2014/jun/01/suspect-arrest-brussels-jewish-museum- 
shooting

90. Perry, Simon and Badi Hasisi. 2015. "Rational Choice Rewards and the Jihadist Suicide Bomber," in Terrorism and Political Violence, 27:1 (53-80): DOI:

10.1080/09546553.2014.962991

91. Pisacane, Carlo. Il Testamento Politico (English: “The Political Manifesto”). Italy, 1857. Accessed online 5 June 2017:

http://www.reteccp.org/biblioteca/disponibili/demos/demoesocial/garibaldi/pisacane/testa mentopisacane.pdf

92. Pisciotta, Barbara. 2010. "L'Europa post comunista dal crollo del Muro di Berlino all'integrazione europea," (English: "Post-communist Europe from the collapse of the Berlin Wall to European integration") in Rivista di Studi Politici Internazionali 77:1 (7791).

93. Pollard, Neal A. 2002. "Globalization's Bastards: Illegitimate Non-State Actors," in International Law, Low Intensity Conflict \& Law Enforcement 11:2-3 (210-238): DOI: 10.1080/0966284042000279009

94. Price, Bryan. 2012. "Targeting Top Terrorists: How Leadership Decapitation Contributes to Counterterrorism," in International Security 36:4 (9-46): https://link.springer.com/chapter/10.1007/978-94-6265-072-5_12

95. Pronin, Emily, Kathleen Kennedy and Sarah Butsch. 2010. "Bombing Versus Negotiating: How Preferences for Combating Terrorism Are Affected by Perceived Terrorist Rationality," in Basic and Applied Social Psychology 28:4 (385-392): DOI: $10.1207 /$ s15324834basp2804 12

96. Quintarelli, Stefano. 2015. "Update: Una Svista Rilevante Nel Provvedimento Antiterrorismo" (English: "A Relevant Sight in Counter-Terrorism Measure"). Stefano Quintarelli: Svolta Digitale.

http://stefanoquintarelli.tumblr.com/post/114529278225/update-una-svista-rilevante-nelprovvedimento

97. Rapoport, David C. "The Four Waves of Modern Terrorism," in Attacking Terrorism: Elements of a Grand Strategy, ed. Audrey Kurth Cronin and James M. Ludes. Washington, DC: Georgetown University Press 2004. 46-73.

http://international.ucla.edu/media/files/Rapoport-Four-Waves-of-Modern-Terrorism.pdf

98. Richardson, Louise. What Do Terrorists Want? Cambridge, Massachusetts: Harvard University Press 2006.

99. Rini, Gianluca. "Terrorismo in Italia: tutte le minacce dell'Isis" (English: "Terrorism in Italy: All of the ISIS Threats [Against Italy]"). Nano Press. Published on 22 January 2016. http://www.nanopress.it/cronaca/2016/01/22/terrorismo-in-italia-tutte-le-minaccedell-isis/47271/ 
100. Rosenthal, Elisabeth. "Italy proposes new powers to counter terrorists." The New York Times. Published on 13 July 20014.

http://www.nytimes.com/2005/07/13/world/europe/italy-proposes-new-powers-tocounter-terrorists.html?_r=0

101. Rúbbelke, Dirk T.G. 2005. "Differing Motivations for Terrorism," in Defence and Peace Economics 16:1 (19-27): DOI: 10.1080/1024269052000323524

102. Russell, Charles and Bowman Miller. 1983. "Profile of a Terrorist," in Perspectives on Terrorism 1:1 (45-60): https://doi.org/10.1080/10576107708435394

103. Sawers, John, former MI6 Chief. "Sir John Sawers's speech - full text." The Guardian. Published on 28 October 2010. https://www.theguardian.com/uk/2010/oct/28/sir-john-sawers-speech-full-text

104. Shaffer, Ryan. 2016. "Jihad and Counter-Jihad in Europe: Islamic Radicals, Right-Wing Extremists, and Counter-Terrorism Responses," in Terrorism and Political Violence 28:2 (383-394): DOI: 10.1080/09546553.2016.1140538

105. Shapiro, Jacob N. 2005. "Organizing Terror: Hierarchy and Networks in Covert Organizations.” Preliminary Draft. Standford University. http://www.teachingterror.net/resources/Shapiro\%20organizing\%20Terror.pdf

106. Shapiro, Jacob N. The Terrorist's Dilemma: Managing Violent Covert Organizations. Princeton, New Jersey: Princeton University Press 2015.

107. Simcox, Robin. "Europe, Stop Trying to Make 'Intelligence Sharing' Happen." Foreign Policy. Published on 14 April 2016. http://foreignpolicy.com/2016/04/14/europestop-trying-to-mak-brussels-paris-bombings/

108. Kalim Siddiqui, speech on "Generating Power without Politics," 14 July 1990. http://kalimsiddiqui.com/writings/

109. Silke, Andrew. "Disengagement or Deradicalization: A Look at Prison Programs for Jailed Terrorists." Combating Terrorism Centre at West Point Publications. Published on 1 January 2011. https://ctc.usma.edu/posts/disengagement-or-deradicalization-a-lookat-prison-programs-for-jailed-terrorists

110. Sloan, Stephen. 2002. "Meeting the Terrorist Threat: The Localization of Counterterrorism Intelligence," in Police Practice and Research 3:4 (337-345): https://doi.org/10.1080/1561426022000032097.

111. T.W. van Dongen. 2011. "Break it Down: An Alternative Approach to Measuring Effectiveness in Counterterrorism," in Journal of Applied Security Research 6:3 (357- 
371): https://doi.org/10.1080/19361610.2011.580264

112. The Government of Italy. 1974. DECRETO 11 aprile 1974, n. 99 Provedimenti urgenti sulla giustizia penale (English: "Decree of 11 April 1974 n.99 Urgent measures on criminal law").

113. The Government of Italy. 1974. LEGGE 7 giugno 1974, n. 220 Nuove norme contro la criminalità (English: "Law of 7 June 1974, n. 220 New Regulations Against Criminality").

114. The Government of Italy. 2009. Costituzione della Repubblicca Italiana (English: "The Constitution of the Republic of Italy"). https://www.senato.it/documenti/repository/istituzione/costituzione.pdf

115. The Government of Italy. 2015. Risoluzione del Parlamento europeo del 25 novembre 2015 sulla prevenzione della radicalizzazione e del reclutamento di cittadini europei da parte di organizzazioni terroristiche. (English: "European Parliament Resolution of 25 November 2015 on the Prevention of Radicalization and Recruitment of European Citizens by Terrorist Organizations"). http:/www.europarl.europa.eu/sides/getDoc.do?pubRef=$\% 2 \mathrm{f} \% 2 \mathrm{fEP} \% 2 \mathrm{f} \% 2 \mathrm{fTEXT} \% 2 \mathrm{bTA} \% 2 \mathrm{bP} 8-\mathrm{TA}-2015$ 0410\%2b0\%2bDOC $\% 2 \mathrm{bXML} \% 2 \mathrm{bV} 0 \% 2 \mathrm{f} \% 2 \mathrm{fIT} \&$ language $=\mathrm{IT}$

116. The Government of Italy. Servizio per i rapporti con le confessioni religiose e per la relazioni istituzionali: Le intesse con le confessioni religose (English: "Service for relations with religious confessions and for institutional relations: The interweaves with religious confessions"). Accessed November 2017.

http://presidenza.governo.it/USRI/confessioni/intese_indice.html

117. The Government of the Republic of Italy: Chief of Defence Staff. Il Concetto Strategico del Capo di Stato Maggiore della Difesa (English: "The Strategic Concept of the Chief of Defense Staff'). Rome: MAECI, 2005.

118. The Government of the Republic of Italy: Ministry of Interior. 2005. Rapporto sullo stato della sicurezza in Italia 2005 (English: "Report on the State of Security in Italy 2005").

http://presidenza.governo.it/GovernoInforma/Dossier/rapporto_sicurezza_2005/rapporto_ annuale_sicurezza.pdf

119. The Government of the Republic of Italy: The Ministry of Foreign Affairs and International Cooperation. 2008. Rapporto 2020. Le scelte di politica estera (English: "Report 2020: Foreign Policy Choices"). http://www.esteri.it/mae/doc/rapporto2020_sceltepoliticaestera_090408.pdf

120. The Government of the Republic of Italy. 1982. Gazzetta ufficiale $n^{\circ} 149$ del 2 giugno 1982 (English: “Official Gazette no. 149 of 2 June 1982”) referenced in "La 
dissociazione politica dal terrorismo" (English: "Political disassociation from terrorism") in Insorgenza. Published on 1 January 2009. https://insorgenze.net/2009/01/01/ladissociazione-politica-dal-terrorismo/

121. The Government of the Republic of Italy. 1987. LEGGE 18 febbraio 1987, no.34 Misure a favore di chi si dissocia dal terrorism (English: "Law of 18 February 1987, no.34 Measures favouring those who have disassociated from terrorism"). http://www.inventati.org/cope/wp/wpcontent/uploads/2015/12/56_legge_18_febbraio_1987_n_34.pdf

122. The Government of the Republic of Italy. 1987. LEGGE 18 febbraio 1987, no.34 Misure a favore di chi si dissocia dal terrorism (English: "Law of 18 February 1987, no.34 Measures favouring those who have disassociated from terrorism"). http://www.inventati.org/cope/wp/wpcontent/uploads/2015/12/56_legge_18_febbraio_1987_n_34.pdf

123. The Government of the Republic of Italy. 2001. DECRETO DEL PRESIDENTE DELLA REPUBBLICA 14 marzo 2001, $n .318$ Regolamento recante disciplina per l'assegnazione delle borse di studio in favore delle vittime del terrorismo e della criminalita', nonche' degli orfani e dei figli delle vittime del terrorismo [English: "DECISION OF THE PRESIDENT OF THE REPUBLIC of 14 March 2001, no. 318 Regulation laying down discipline for granting scholarships in favor of victims of terrorism and crime, as well as of orphans and children of victims of terrorism"].

124. The Government of the Republic of Italy. 2005. Amendments made in DECRETO-LEGGE 27 luglio 2005, n. 144 Misure urgenti per il contrasto del terrorismo internazionale (English: "DECREE-LAW 27 July 2005, no. 144 Urgent measures to counter international terrorism”). http://www.camera.it/parlam/leggi/decreti/05144d.htm

125. The Government of the Republic of Italy. 2005. LEGGE 31 luglio 2005, n. 155 Conversione in legge, con modificazioni, del decreto-legge 27 luglio 2005, n. 144, recante misure urgenti per il contrasto del terrorismo internazionale (English: "LAW 31 July 2005, n. 155 Conversion into law, with amendments, of the decree-law 27 July 2005, n. 144, containing urgent measures for the fight against international terrorism").

126. The Government of the Republic of Italy. 2005. LEGGE 31 luglio 2005, n. 155 Conversione in legge, con modificazioni, del decreto-legge 27 luglio 2005, n. 144, recante misure urgenti per il contrasto del terrorismo internazionale. (English: "LAW 31 July 2005, no. 155 Conversion into law, with modifications, of Decree-Law no. 144, urging urgent measures to counter international terrorism.”) http://gazzette.comune.jesi.an.it/2005/177/3.htm

127. The Government of the Republic of Italy. 2007. DECRETO LEGISLATIVO 6 febbraio 2007, n. 30 Attuazione della direttiva 2004/38/CE relativa al diritto dei cittadini dell'Unione e dei loro familiari di circolare e di soggiornare liberamente nel territorio degli Stati membri (English: "Legislative Decree 6 February 2007, n.30 Implementation 
of Directive 2004/38 / EC on the right of citizens of the Union and their family members to move and reside freely within the territory of the Member States").

http://www.esteri.it/mae/normative/normativa_consolare/visti/d_lgs_30_2007.pdf

128. The Government of the Republic of Italy. 2007. DECRETO-LEGGE 29 dicembre 2007, n. 24 Misure urgenti in materia di espulsioni e di allontanamenti per terrorismo e per motivi imperativi di pubblica sicurezza. (English: "DECREE-LAW 29 December 2007, no. 249 Urgent measures on extradition and expulsion for terrorism and for imperative reasons of public security").

http://www.camera.it/parlam/leggi/decreti/07249d.htm

129. The Government of the Republic of Italy. 2015. LEGGE 17 aprile 2015, n. 43 Conversione in legge, con modificazioni, del decreto-legge 18 febbraio 2015, $n$. 7 , recante misure urgenti per il contrasto del terrorismo, anche di matrice internazionale, nonche' proroga delle missioni internazionali delle Forze armate e di polizia, iniziative di cooperazione allo sviluppo e sostegno ai processi di ricostruzione e partecipazione alle iniziative delle Organizzazioni internazionali per il consolidamento dei processi di pace e di stabilizzazione (English: "LAW 17 April 2015, n. 43 Conversion into law, with modifications, of the decree-law of February 18, 2015, n. 7 on urgent measures to counter terrorism, including an international matrix, as well as the extension of the international missions and police missions, development co-operation initiatives and support for reconstruction processes and participation in the initiatives of international organizations for consolidation of peace and stabilization processes").

130. The Government of the Republic of Italy. 2016. LEGGE 28 luglio 2016, n. 153 Norme per il contrasto al terrorismo, nonche' ratifica ed esecuzione: a) della Convenzione del Consiglio d'Europa per la prevenzione del terrorismo, fatta a Varsavia il 16 maggio 2005; b) della Convenzione internazionale per la soppressione di atti di terrorismo nucleare, fatta a New York il 14 settembre 2005; c) del Protocollo di Emendamento alla Convenzione europea per la repressione del terrorismo, fatto a Strasburgo il 15 maggio 2003; d) della Convenzione del Consiglio d'Europa sul riciclaggio, la ricerca, il sequestro e la confisca dei proventi di reato e sul finanziamento del terrorismo, fatta a Varsavia il 16 maggio 2005; e) del Protocollo addizionale alla Convenzione del Consiglio d'Europa per la prevenzione del terrorismo, fatto a Riga il 22 ottobre 2015 (English: "LAW 28 July 2016, no. 153 'Standards for countering terrorism, as well as ratification and execution: a) of the Council of Europe Convention for the Prevention of Terrorism, done in Warsaw on 16 May 2005; (b) of the International Convention for the Suppression of Nuclear Terrorism, done at New York on 14 September 2005; (c) of the Protocol to the European Convention for the Suppression of Terrorism, done at Strasbourg on 15 May 2003; (d) of the Council of Europe Convention on Laundering, Search, Seizure and Confiscation of proceeds of crime and the financing of terrorism, done at Warsaw on 16 May 2005; (e) of the Additional Protocol to the Council of Europe Convention for the Prevention of Terrorism, done at Riga on 22 October 2015”). 
131. The Government of the Republic of Italy. 2017. Misure per la prevenzione della radicalizzazione e dell'estremismo violento di matrice jihadista A.C. 3558-A. (English: "Measures for the Prevention of Jihadist Radicalism and Violent Extremism"). http://documenti.camera.it/Leg17/Dossier/Pdf/AC0573A.Pdf

132. Tibi, Bassam. "Muslim Migrants in Europe: Between Euro-Islam and Ghettoization." In Muslim Europe or Euro-Islam, edited by Nezar AlSayyad and Manel Castel. New York: Lexington Books 2002.

133. Tzu, Sun (Translated by Thomas Cleary). The Art of War. Boston, Massachusetts: Shambalah Press 1988 (2015 ed.).

134. United Nations. 2014. United Nations Security Council Resolution 2178/2014 on Foreign Terrorist Fighters. http://www.un.org/en/sc/ctc/docs/2015/SCR\%202178_2014_EN.pdf

135. U.S. Department of Defense. 21st Century Complete Guide to Terrorism and the Government Response to September 11th: including Al Qaeda (al-Qaida) Training Manual. New York, N.Y.: Progressive Management 2002.

136. Van Dongen MA, T.W. 2011. "Break it Down: An Alternative Approach to Measuring Effectiveness in Counterterrorism," in Journal of Applied Security Research 6:3 (357-371): DOI: 10.1080/19361610.2011.580264

137. Van Ginkel, B., and E. Entenmann. 2016. "The Foreign Fighters Phenomenon in the Euopean Union: Profiles, Threats \& Policies." International Centre for CounterTerrorism - The Hague 7:2. https://icct.nl/publication/report-the-foreign-fightersphenomenon-in-the-eu-profiles-threats-policies/

138. Van Um, Eric. 2011. "Discussing Concepts of Terrorist Rationality: Implications for Counterterrorism Policy," Defence and Peace Economics 22 no.2, 161-179.

139. Van Um, Eric and Daniela Pisoiu. 2011. "Effective Counterterrorism: What Have We Learned So Far?” Economics of Security Working Paper Series from DIW Berlin, German Institute for Economic Research. https://econpapers.repec.org/paper/diwdiweos/diweos55.htm

140. Van Um, Eric and Daniela Pisoiu. 2015. "Dealing with uncertainty: the illusion of knowledge in the study of counterterrorism effectiveness," in Critical Studies on Terrorism 8:2 (229-245): DOI: 10.1080/17539153.2014.981400

141. Van Zuijdewijn, Jeanine de Roy and Edwin Bakker. "Returning Western foreign fighters: The case of Afghanistan, Bosnia and Somalia," International Centre for Counter-terrorism - The Hague. Background note published in June 2014. https://www.icct.nl/download/file/ICCT-De-Roy-van-Zuijdewijn-Bakker-Returning- 
Western-Foreign-Fighters-June-2014.pdf

142. Venturi, Ilaria. "La Costituzione spiegata agli imam, il primo corso a Ravenna" (English: "The Constitution will be taught to imams, the first course in Ravenna"). La Repubblica - Bologna. Published on 10 January 2017. http://bologna.repubblica.it/cronaca/2017/01/10/news/ravenna_1_ateneo_promuove_un_c orso_per_imam_sulla_costituzione-155750496/

143. Vidino, Lorenzo. "Report: Home-Grown Jihadism in Italy." Istituto per gli Studi di Politica Internazionale. Published on 29 April 2014. www.ispionline.it/it/pubblicazione/home-grown-jihadism-italy-10309

144. Vidino, Lorenzo. 2008. "Islam, Islamism, and Jihadism in Italy." Hudson Institute. https://www.hudson.org/research/9813-islam-islamism-and-jihadism-in-italy

145. Vidino, Lorenzo. 2013. "The Evolution of Jihadism in Italy: Rise in Homegrown Radicals," in CTC Sentinel 6:11 (17-20). https://ctc.usma.edu/wpcontent/uploads/2013/11/CTCSentinel-Vol6Iss11-12.pdf

146. Vidino, Lorenzo. Il jihadismo autoctono in Italia (English: "Homegrown Jihadism in Italy"). Milan: ISPI Publications 2015. www.ispionline.it/it/Ebook/Il_jihadismo_autoctono_in_Italia.pdf

147. Vidino, Lorenzo, Francesco Marone and Eva Entenmann. Fear Thy Neighbour: Radicalization and Jihadist Attacks in the West. Milan: ISPI Publications 2015. https:/extremism.gwu.edu/sites/extremism.gwu.edu/files/FearThyNeighbor\%20Radicaliz ationandJihadistAttacksintheWest.pdf

148. Violante, L. "Politica della sicurezza, relazioni internationali e terrorismo," in La Provadelle Armi, ed. G. Pasquino. Bologna: Il Mulino, 1984.

149. Walsh, James I. 2006. "Intelligence-Sharing in the European Union: Institutions are not Enough," in JCMS 44:3. Jamesigoewalsh.com/jcms.pdf

150. Walsh, James Igoe. 2009. "Security Policy and Intelligence Cooperation in the European Union." Paper prepared for the biennial meeting of the European Union in April 2009. http://www.euce.org/eusa2009/papers/walsh_12C.pdf

151. Walt, Stephen M., “International Relations: One World, Many Theories.” Foreign Policy. Published in Spring 1998.

http://www.columbia.edu/itc/sipa/S6800/courseworks/foreign_pol_walt.pdf

152. Wensik, Wim et al. 2017. “The European Union's Policies on Counter-Terrorism: Relevance, Coherence, and Effectiveness." International Centre for Counter-TerrorismThe Hague.

http://www.europarl.europa.eu/RegData/etudes/STUD/2017/583124/IPOL_STU(2017)58 


\section{4_EN.pdf}

153. Wilner, Alex. Deterring Rational Fanatics. Philadelphia: University of Pennsylvania Press 2015.

154. Zimmermann, Doron. 2006. "The European Union and Post-9/11 Counterterrorism: A Reappraisal," in Studies in Conflict \& Terrorism 29:2 (123-145): DOI: $10.1080 / 10576100500522215$

155. --. "Al Qaeda letter on the importance of kidnapping revenue." The New York Times. Published on 29 July 2014.

https://www.nytimes.com/interactive/2014/07/30/world/africa/31kidnapdocviewer2.html?_r=0

156. --. “Chapter 4. Views of Roma, Muslims, Jews.” Pew Research Centre. Published on 12 May 2014. http://www.pewglobal.org/2014/05/12/chapter-4-views-of-romamuslims-jews/

$157 . \quad--$ Eurpol's History. Europol. https://www.europol.europa.eu/content/page/history-149

158. --. "Foreign fighters in Iraq and Syria: Where do they come from?" Radio Free Europe/Radio Liberty. Accessed on 28 April 2016.

http://www.rferl.org/contentinfographics/foreign-fighters-syria-iraq-is-isis-isilinfographic/26584940.html

159. --. "Isis in Libya: Gentiloni and al-Sarraj express deep concern." News on Italy at the UN. Published on 5 January 2016. http://www.onuitalia.com/eng/2016/01/05/isis/

160. --. La radicalizzazione del terrorismo islamico: Elementi per uno studio del fenomeno di proselitismo in carcere (English: "The radicalization of Islamic terrorism: Elements for a study of the phenomenon of proselytism in prison"). Qaderni ISSP: Istituto Superiore di Studi Penitenziari. June 2012.

https://www.giustizia.it/resources/cms/documents/radicalizzazione_del_terrorismo_isla mico.pdf

161. --. "L'Isis ha minacciato du nuovo l'Italia, dobbiamo preoccuparici?" (English: "ISIS has threatened Italy again, should we be worried?"). Il Post. Published on 21 August 2017. http://www.ilpost.it/2017/08/21/isis-minacce-italia-attentati/

162. --. "Terrorismo: annullate condanne jihadisti" (English: "Terrorism: cancelled jihadist convictions"). Quotidiano. Published on 15 July 2016. http://www.quotidiano.net/cronaca/terrorismo-annullate-condanne-jihadisti-1.2349194

163. --. "Terrorismo, la minaccia dell'Isis: 'Prossimo obiettivo è l'Italia'. Viminale espelle 3 stranieri." (English: "Terrorism, the ISIS threat: 'the next target is Italy'. 
Viminal expels three foreigners.") La Repubblica. Published on 19 August 2017. http://www.repubblica.it/cronaca/2017/08/19/news/paura_terrorismo_espulsi_dall_italia_ due_marocchini_e_un_siriano-173367567/

164. --. "Using GTD." Global Terrorism Database. http://www.start.umd.edu/gtd/using-gtd/ 
- Council Regulation (EC) No 2580/2001 of 27 December 2001 on specific restrictive measures directed against certain persons and entities with a view to combating terrorism

- 2001/927/EC: Council Decision of 27 December 2001 establishing the list provided for in Article 2(3) of Council Regulation (EC) No 2580/2001 on specific restrictive measures directed against certain persons and entities with a view to combating terrorism

- 2002/334/EC: Council Decision of 2 May 2002 implementing Article 2(3) of Regulation (EC) No 2580/2001 on specific restrictive measures directed against certain persons and entities with a view to combating terrorism and repealing Decision 2001/927/EC

- Council Framework Decision 2002/475/JHA of 13 June 2002 on combating terrorism

- Council Framework Decision of 13 June 2002 on combating terrorism

- 2002/460/EC: Council Decision of 17 June 2002 implementing Article 2(3) of Regulation (EC) No 2580/2001 on specific restrictive measures directed against certain persons and entities with a view to combating terrorism and repealing Decision 2002/334/EC

- Commission Regulation (EC) No 1883/2002 of 22 October 2002 amending Council Regulation (EC) No 1081/2000 prohibiting the sale, supply and export to Burma/Myanmar of equipment which might be used for internal repression or terrorism, and freezing the funds of certain persons related to important governmental functions in that country

- 2002/848/EC: Council Decision of 28 October 2002 implementing Article 2(3) of Regulation (EC) No 2580/2001 on specific restrictive measures directed against certain persons and entities with a view to combating terrorism and repealing Decision 2002/460/EC

- 2002/996/JHA: Council Decision of 28 November 2002 establishing a mechanism for evaluating the legal systems and their implementation at national level in the fight against terrorism

- 2002/974/EC: Council Decision of 12 December 2002 implementing Article 2(3) of Regulation (EC) No 2580/2001 on specific restrictive measures directed against certain persons and entities with a view to combating terrorism and repealing Decision 2002/848/EC

- Council Decision 2003/48/JHA of 19 December 2002 on the implementation of specific measures for police and judicial cooperation to combat terrorism in accordance with Article 4 of Common Position 2001/931/CFSP

- Commission Regulation (EC) No 745/2003 of 28 April 2003 amending Council Regulation (EC) No 2580/2001 on specific measures directed against certain persons and entities with a view to combating terrorism 
- Commission Regulation (EC) No 744/2003 of 28 April 2003 amending, for the second time, Council Regulation (EC) No 1081/2000 prohibiting the sale, supply and export to Burma/Myanmar of equipment which might be used for internal repression or terrorism, and freezing the funds of certain persons related to important governmental functions in that country

- Commission Regulation (EC) No 1070/2003 of 20 June 2003 amending, for the third time, Council Regulation (EC) No 1081/2000 prohibiting the sale, supply and export to Burma/Myanmar of equipment which might be used for internal repression or terrorism, and freezing the funds of certain persons related to important governmental functions in that country

- 2003/480/EC: Council Decision of 27 June 2003 implementing Article 2(3) of Regulation (EC) No 2580/2001 on specific restrictive measures directed against certain persons and entities with a view to combating terrorism and repealing Decision 2002/974/EC

- Council Regulation (EC) No 1211/2003 of 7 July 2003 amending Regulation (EC) No 1081/2000 prohibiting the sale, supply and export to Burma/Myanmar of equipment which might be used for internal repression or terrorism, and freezing the funds of certain persons related to important governmental functions in that country

- 2003/646/EC: Council Decision of 12 September 2003 implementing Article 2(3) of Regulation (EC) No 2580/2001 on specific restrictive measures directed against certain persons and entities with a view to combating terrorism and repealing Decision 2003/480/EC

- Commission Regulation (EC) No 2084/2003 of 27 November 2003 amending Council Regulation (EC) No 1081/2000 prohibiting the sale, supply and export to Burma/Myanmar of equipment which might be used for internal repression or terrorism, and freezing the funds of certain persons related to important governmental functions in that country

- 2003/902/EC: Council Decision of 22 December 2003 implementing Article 2(3) of Regulation (EC) No 2580/2001 on specific restrictive measures directed against certain persons and entities with a view to combating terrorism and repealing Decision 2003/646/EC

- Commission Regulation (EC) No 2297/2003 of 23 December 2003 amending Council Regulation (EC) No 1081/2000 prohibiting the sale, supply and export to Burma/Myanmar of equipment which might be used for internal repression or terrorism, and freezing the funds of certain persons related to important governmental functions in that country

- 2004/306/EC: Council Decision of 2 April 2004 implementing Article 2(3) of Regulation (EC) No 2580/2001 on specific restrictive measures directed against certain persons and entities with a view to combating terrorism and repealing Decision 2003/902/EC 
- Council Regulation (EC) No 871/2004 of 29 April 2004 concerning the introduction of some new functions for the Schengen Information System, including in the fight against terrorism

- Council Decision 2005/211/JHA of 24 February 2005 concerning the introduction of some new functions for the Schengen Information System, including in the fight against terrorism

- Council Decision 2005/221/CFSP of 14 March 2005 implementing Article 2(3) of Regulation (EC) No 2580/2001 on specific restrictive measures directed against certain persons and entities with a view to combating terrorism and repealing Decision 2004/306/EC

- Council Decision 2005/428/CFSP of 6 June 2005 implementing Article 2(3) of Regulation (EC) No 2580/2001 on specific restrictive measures directed against certain persons and entities with a view to combating terrorism and repealing Decision 2005/221/CFSP

- Council Decision 2005/451/JHA of 13 June 2005 fixing the date of application of certain provisions of Regulation (EC) No 871/2004 concerning the introduction of some new functions for the Schengen Information System, including in the fight against terrorism

- Commission Regulation (EC) No 1207/2005 of 27 July 2005 amending Council Regulation (EC) No 2580/2001 on specific measures directed against certain persons and entities with a view to combating terrorism

- Council Decision 2005/671/JHA of 20 September 2005 on the exchange of information and cooperation concerning terrorist offences

- Council Decision 2005/727/JHA of 12 October 2005 fixing the date of application of certain provisions of Decision 2005/211/JHA concerning the introduction of some new functions for the Schengen Information System, including the fight against terrorism

- Council Decision 2005/728/JHA of 12 October 2005 fixing the date of application of certain provisions of Regulation (EC) No 871/2004 concerning the introduction of some new functions for the Schengen Information System, including in the fight against terrorism

- Council Decision 2005/719/JHA of 12 October 2005 fixing the date of application of certain provisions of Decision 2005/211/JHA concerning the introduction of some new functions for the Schengen Information System, including in the fight against terrorism

- 2005/722/EC: Council Decision of 17 October 2005 implementing Article 2(3) of Regulation (EC) No 2580/2001 on specific restrictive measures directed against certain persons and entities with a view to combating terrorism and repealing Decision 2005/428/CFSP

- Council Common Position 2005/725/CFSP of 17 October 2005 updating Common Position 2001/931/CFSP on the application of specific measures to combat terrorism and repealing Common Position 2005/427/CFSP 
- Corrigendum to Council Decision 2005/722/EC of 17 October 2005 implementing Article 2(3) of Regulation (EC) No 2580/2001 on specific restrictive measures directed against certain persons and entities with a view to combating terrorism and repealing Decision 2005/428/CFSP (OJ L 272, 18.10.2005)

- Directive 2005/60/EC of the European Parliament and of the Council of 26 October 2005 on the prevention of the use of the financial system for the purpose of money laundering and terrorist financing (Text with EEA relevance)

- Commission Regulation (EC) No 1957/2005 of 29 November 2005 amending Council Regulation (EC) No 2580/2001 on specific restrictive measures directed against certain persons and entities with a view to combating terrorism

- Council Decision 2005/848/EC of 29 November 2005 implementing Article 2(3) of Regulation (EC) No 2580/2001 on specific restrictive measures directed against certain persons and entities with a view to combating terrorism and repealing Decision 2005/722/EC

- 2005/930/EC: Council Decision of 21 December 2005 implementing Article 2(3) of Regulation (EC) No 2580/2001 on specific restrictive measures directed against certain persons and entities with a view to combating terrorism and repealing Decision 2005/848/EC

- Council Decision 2006/228/JHA of 9 March 2006 fixing the date of application of certain provisions of Decision 2005/211/JHA concerning the introduction of some new functions for the Schengen Information System, including the fight against terrorism

- Council Decision 2006/229/JHA of 9 March 2006 fixing the date of application of certain provisions of Decision 2005/211/JHA concerning the introduction of some new functions for the Schengen Information System, including in the fight against terrorism

- 2006/379/EC: Council Decision of 29 May 2006 implementing Article 2(3) of Regulation (EC) No 2580/2001 on specific restrictive measures directed against certain persons and entities with a view to combating terrorism and repealing Decision 2005/930/EC

- Council Decision 2006/631/JHA of 24 July 2006 fixing the date of application of certain provisions of Decision 2005/211/JHA concerning the introduction of some new functions for the Schengen Information System, including in the fight against terrorism

- 2006/628/EC: Council Decision of 24 July 2006 fixing the date of application of Article 1(4) and (5) of Regulation (EC) No 871/2004 concerning the introduction of some new functions for the Schengen Information System, including in the fight against terrorism

- Commission Regulation (EC) No 1461/2006 of 29 September 2006 amending Council Regulation (EC) No 2580/2001 on specific restrictive measures directed against certain persons and entities with a view to combating terrorism

- 2006/1008/EC: Council Decision of 21 December 2006 implementing Article 2(3) of Regulation (EC) No 2580/2001 on specific restrictive measures directed against certain persons and entities with a view to combating terrorism 
- 2007/124/EC,Euratom: Council Decision of 12 February 2007 establishing for the period 2007 to 2013, as part of General Programme on Security and Safeguarding Liberties, the Specific Programme Prevention, Preparedness and Consequence Management of Terrorism and other Security related risks

- 2007/445/EC: Council Decision of 28 June 2007 implementing Article 2(3) of Regulation (EC) No 2580/2001 on specific restrictive measures directed against certain persons and entities with a view to combating terrorism and repealing Decisions 2006/379/EC and 2006/1008/EC

- 2007/868/EC: Council Decision of 20 December 2007 implementing Article 2(3) of Regulation (EC) No 2580/2001 on specific restrictive measures directed against certain persons and entities with a view to combating terrorism and repealing Decision 2007/445/EC

- Directive 2008/20/EC of the European Parliament and of the Council of 11 March 2008 amending Directive 2005/60/EC on the prevention of the use of the financial system for the purpose of money laundering and terrorist financing, as regards the implementing powers conferred on the Commission (Text with EEA relevance)

- 2008/342/EC: Council Decision of 29 April 2008 amending Decision 2007/868/EC implementing Article 2(3) of Regulation (EC) No 2580/2001 on specific restrictive measures directed against certain persons and entities with a view to combating terrorism

- 2008/343/EC: Council Decision of 29 April 2008 amending Decision 2007/868/EC implementing Article 2(3) of Regulation (EC) No 2580/2001 on specific restrictive measures directed against certain persons and entities with a view to combating terrorism

- Council Decision 2008/615/JHA of 23 June 2008 on the stepping up of cross-border cooperation, particularly in combating terrorism and cross-border crime

- Council Decision 2008/616/JHA of 23 June 2008 on the implementation of Decision 2008/615/JHA on the stepping up of cross-border cooperation, particularly in combating terrorism and cross-border crime

- Council Decision 2008/633/JHA of 23 June 2008 concerning access for consultation of the Visa Information System (VIS) by designated authorities of Member States and by Europol for the purposes of the prevention, detection and investigation of terrorist offences and of other serious criminal offences

- 2008/583/EC: Council Decision of 15 July 2008 implementing Article 2(3) of Regulation (EC) No 2580/2001 on specific restrictive measures directed against certain persons and entities with a view to combating terrorism and repealing Decision 2007/868/EC

- Council Framework Decision 2008/919/JHA of 28 November 2008 amending Framework Decision 2002/475/JHA on combating terrorism

- Council Framework Decision 2008/919/JHA of 28 November 2008 amending Framework Decision 2002/475/JHA on combating terrorism

- 2009/62/EC: Council Decision of 26 January 2009 implementing Article 2(3) of Regulation (EC) No 2580/2001 on specific restrictive measures directed against certain 
persons and entities with a view to combating terrorism and repealing Decision 2008/583/EC

- Council Regulation (EC) No 501/2009 of 15 June 2009 implementing Article 2(3) of Regulation (EC) No 2580/2001 on specific restrictive measures directed against certain persons and entities with a view to combating terrorism and repealing Decision 2009/62/EC

- Corrigendum to Council Regulation (EC) No 501/2009 of 15 June 2009 implementing Article 2(3) of Regulation (EC) No 2580/2001 on specific restrictive measures directed against certain persons and entities with a view to combating terrorism and repealing Decision 2009/62/EC (OJ L 151, 16.6.2009)

- Council Decision of 21 September 2009 on the signing, on behalf of the European Union, and on the provisional application of certain provisions of the Agreement between the European Union and Iceland and Norway on the application of certain provisions of Council Decision 2008/615/JHA on the stepping up of cross-border cooperation, particularly in combating terrorism and cross-border crime and Council Decision 2008/616/JHA on the implementation of Decision 2008/615/JHA on the stepping up of cross-border cooperation, particularly in combating terrorism and cross-border crime, and the Annex thereto

- Council Decision 2010/16/CFSP/JHA of 30 November 2009 on the signing, on behalf of the European Union, of the Agreement between the European Union and the United States of America on the processing and transfer of Financial Messaging Data from the European Union to the United States for purposes of the Terrorist Finance Tracking Program

- Council Implementing Regulation (EU) No 1285/2009 of 22 December 2009 implementing Article 2(3) of Regulation (EC) No 2580/2001 on specific restrictive measures directed against certain persons and entities with a view to combating terrorism and repealing Regulation (EC) No 501/2009

- Council Decision 2009/1004/CFSP of 22 December 2009 updating the list of persons, groups and entities subject to Articles 2, 3 and 4 of Common Position 2001/931/CFSP on the application of specific measures to combat terrorism

- Corrigendum to Council Common Position 2009/468/CFSP of 15 June 2009 updating Common Position 2001/931/CFSP on the application of specific measures to combat terrorism and repealing Common Position 2009/67/CFSP ( OJ L 151, 16.6.2009)

- Council Decision 2010/16/CFSP/JHA of 30 November 2009 on the signing, on behalf of the European Union, of the Agreement between the European Union and the United States of America on the processing and transfer of Financial Messaging Data from the European Union to the United States for purposes of the Terrorist Finance Tracking Program\#Agreement between the European Union and the United States of America on the processing and transfer of Financial Messaging Data from the European Union to the United States for purposes of the Terrorist Finance Tracking Program 
- 2010/411/: Council Decision of 28 June 2010 on the signing, on behalf of the Union, of the Agreement between the European Union and the United States of America on the processing and transfer of financial messaging data from the European Union to the United States for the purposes of the Terrorist Finance Tracking Program

- 2010/386/CFSP: Council Decision 2010/386/CFSP of 12 July 2010 updating the list of persons, groups and entities subject to Articles 2, 3 and 4 of Common Position 2001/931/CFSP on the application of specific measures to combat terrorism

- Council Implementing Regulation (EU) No 610/2010 of 12 July 2010 implementing Article 2(3) of Regulation (EC) No 2580/2001 on specific restrictive measures directed against certain persons and entities with a view to combating terrorism and repealing Implementing Regulation (EU) No 1285/2009

- Council Implementing Regulation (EU) No 610/2010 of 12 July 2010 implementing Article 2(3) of Regulation (EC) No 2580/2001 on specific restrictive measures directed against certain persons and entities with a view to combating terrorism and repealing Implementing Regulation (EU) No 1285/2009

- 2010/412/: Council Decision of 13 July 2010 on the conclusion of the Agreement between the European Union and the United States of America on the processing and transfer of Financial Messaging Data from the European Union to the United States for the purposes of the Terrorist Finance Tracking Program

- 2010/482/EU: Council Decision of 26 July 2010 on the conclusion of the Agreement between the European Union and Iceland and Norway on the application of certain provisions of Council Decision 2008/615/JHA on the stepping up of cross-border cooperation, particularly in combating terrorism and cross-border crime and Council Decision 2008/616/JHA on the implementation of Decision 2008/615/JHA on the stepping up of cross-border cooperation, particularly in combating terrorism and crossborder crime, and the Annex thereto

- 2010/412/: Council Decision of 13 July 2010 on the conclusion of the Agreement between the European Union and the United States of America on the processing and transfer of Financial Messaging Data from the European Union to the United States for the purposes of the Terrorist Finance Tracking Program\#Agreement between the European Union and the United States of America on the processing and transfer of Financial Messaging Data from the European Union to the United States for the purposes of the Terrorist Finance Tracking Program

- Corrigendum to Council Decision 2010/412/EU of 13 July 2010 on the conclusion of the Agreement between the European Union and the United States of America on the processing and transfer of Financial Messaging Data from the European Union to the United States for the purposes of the Terrorist Finance Tracking Program ( OJ L 195, 27.7.2010) 
- Council Decision 2011/70/CFSP of 31 January 2011 updating the list of persons, groups and entities subject to Articles 2, 3 and 4 of Common Position 2001/931/CFSP on the application of specific measures to combat terrorism

- Council Implementing Regulation (EU) No 83/2011 of 31 January 2011 implementing Article 2(3) of Regulation (EC) No 2580/2001 on specific restrictive measures directed against certain persons and entities with a view to combating terrorism and repealing Implementing Regulation (EU) No 610/2010

- Council Implementing Regulation (EU) No 83/2011 of 31 January 2011 implementing Article 2(3) of Regulation (EC) No 2580/2001 on specific restrictive measures directed against certain persons and entities with a view to combating terrorism and repealing Implementing Regulation (EU) No 610/2010

- Council Decision 2011/430/CFSP of 18 July 2011 updating the list of persons, groups and entities subject to Articles 2, 3 and 4 of Common Position 2001/931/CFSP on the application of specific measures to combat terrorism

- Council Implementing Regulation (EU) No 687/2011 of 18 July 2011 implementing Article 2(3) of Regulation (EC) No 2580/2001 on specific restrictive measures directed against certain persons and entities with a view to combating terrorism, and repealing Implementing Regulations (EU) No 610/2010 and (EU) No 83/2011

- Council Implementing Regulation (EU) No 687/2011 of 18 July 2011 implementing Article 2(3) of Regulation (EC) No 2580/2001 on specific restrictive measures directed against certain persons and entities with a view to combating terrorism, and repealing Implementing Regulations (EU) No 610/2010 and (EU) No 83/2011

- 2011/701/CFSP: Council Decision 2011/701/CFSP of 21 October 2011 amending Decision 2011/430/CFSP in order to update the list of persons, groups and entities subject to Articles 2, 3 and 4 of Common Position 2001/931/CFSP on the application of specific measures to combat terrorism

- Council Implementing Regulation (EU) No 1063/2011 of 21 October 2011 implementing Article 2(3) of Regulation (EC) No 2580/2001 on specific restrictive measures directed against certain persons and entities with a view to combating terrorism

- Council Implementing Regulation (EU) No 1063/2011 of 21 October 2011 implementing Article 2(3) of Regulation (EC) No 2580/2001 on specific restrictive measures directed against certain persons and entities with a view to combating terrorism

- Council Decision 2011/872/CFSP of 22 December 2011 updating the list of persons, groups and entities subject to Articles 2, 3 and 4 of Common Position 2001/931/CFSP on the application of specific measures to combat terrorism and repealing Decision 2011/430/CFSP

- Council Implementing Regulation (EU) No 1375/2011 of 22 December 2011 implementing Article 2(3) of Regulation (EC) No 2580/2001 on specific restrictive measures directed against certain persons and entities with a view to combating terrorism and repealing Implementing Regulation (EU) No 687/2011 
- Council Implementing Regulation (EU) No 1375/2011 of 22 December 2011 implementing Article 2(3) of Regulation (EC) No 2580/2001 on specific restrictive measures directed against certain persons and entities with a view to combating terrorism and repealing Implementing Regulation (EU) No 687/2011

- Council Decision 2012/150/CFSP of 13 March 2012 amending Decision 2011/872/CFSP updating the list of persons, groups and entities subject to Articles 2, 3 and 4 of Common Position 2001/931/CFSP on the application of specific measures to combat terrorism

- Council Implementing Regulation (EU) No 213/2012 of 13 March 2012 amending Implementing Regulation (EU) No 1375/2011 implementing Article 2(3) of Regulation (EC) No 2580/2001 on specific restrictive measures directed against certain persons and entities with a view to combating terrorism

- Council Implementing Regulation (EU) No 213/2012 of 13 March 2012 amending Implementing Regulation (EU) No 1375/2011 implementing Article 2(3) of Regulation (EC) No 2580/2001 on specific restrictive measures directed against certain persons and entities with a view to combating terrorism

- 2012/290/EU: Decision of the US-EU Joint Customs Cooperation Committee of 4 May 2012 regarding mutual recognition of the Customs-Trade Partnership Against Terrorism program in the United States and the Authorised Economic Operators programme of the European Union

- Council Decision 2012/333/CFSP of 25 June 2012 updating the list of persons, groups and entities subject to Articles 2, 3 and 4 of Common Position 2001/931/CFSP on the application of specific measures to combat terrorism and repealing Decision 2011/872/CFSP

- Council Implementing Regulation (EU) No 542/2012 of 25 June 2012 implementing Article 2(3) of Regulation (EC) No 2580/2001 on specific restrictive measures directed against certain persons and entities with a view to combating terrorism and repealing Implementing Regulation (EU) No 1375/2011

- Council Implementing Regulation (EU) No 542/2012 of 25 June 2012 implementing Article 2(3) of Regulation (EC) No 2580/2001 on specific restrictive measures directed against certain persons and entities with a view to combating terrorism and repealing Implementing Regulation (EU) No 1375/2011

- Council Decision 2012/686/CFSP of 6 November 2012 amending Decision 2012/333/CFSP updating the list of persons, groups and entities subject to Articles 2, 3 and 4 of Common Position 2001/931/CFSP on the application of specific measures to combat terrorism

- Council Implementing Regulation (EU) No 1015/2012 of 6 November 2012 amending Implementing Regulation (EU) No 542/2012 implementing Article 2(3) of Regulation (EC) No 2580/2001 on specific restrictive measures directed against certain persons and entities with a view to combating terrorism 
- Council Implementing Regulation (EU) No 1015/2012 of 6 November 2012 amending Implementing Regulation (EU) No 542/2012 implementing Article 2(3) of Regulation (EC) No 2580/2001 on specific restrictive measures directed against certain persons and entities with a view to combating terrorism

- Council Decision 2012/765/CFSP of 10 December 2012 updating the list of persons, groups and entities subject to Articles 2, 3 and 4 of Common Position 2001/931/CFSP on the application of specific measures to combat terrorism and repealing Decision 2012/333/CFSP

- Council Implementing Regulation (EU) No 1169/2012 of 10 December 2012 implementing Article 2(3) of Regulation (EC) No 2580/2001 on specific restrictive measures directed against certain persons and entities with a view to combating terrorism and repealing Implementing Regulation (EU) No 542/2012

- Council Implementing Regulation (EU) No 1169/2012 of 10 December 2012 implementing Article 2(3) of Regulation (EC) No 2580/2001 on specific restrictive measures directed against certain persons and entities with a view to combating terrorism and repealing Implementing Regulation (EU) No 542/2012

- Commission Implementing Regulation (EU) No 1250/2012 of 20 December 2012 amending Council Regulation (EC) No 2580/2001 on specific restrictive measures directed against certain persons and entities with a view to combating terrorism

- Commission Implementing Regulation (EU) No 1250/2012 of 20 December 2012 amending Council Regulation (EC) No 2580/2001 on specific restrictive measures directed against certain persons and entities with a view to combating terrorism

- Commission Implementing Regulation (EU) No 646/2013 of 4 July 2013 amending Council Regulation (EC) No 2580/2001 on specific restrictive measures directed against certain persons and entities with a view to combating terrorism

- Commission Implementing Regulation (EU) No 646/2013 of 4 July 2013 amending Council Regulation (EC) No 2580/2001 on specific restrictive measures directed against certain persons and entities with a view to combating terrorism

- 2013/392/: Council Decision of 22 July 2013 fixing the date of effect of Decision 2008/633/JHA concerning access for consultation of the Visa Information System (VIS) by designated authorities of Member States and by Europol for the purposes of the prevention, detection and investigation of terrorist offences and of other serious criminal offences

- 2013/395/CFSP: Council Decision 2013/395/CFSP of 25 July 2013 updating and amending the list of persons, groups and entities subject to Articles 2, 3 and 4 of Common Position 2001/931/CFSP on the application of specific measures to combat terrorism, and repealing Decision 2012/765/CFSP

- Council Implementing Regulation (EU) No 714/2013 of 25 July 2013 implementing Article 2(3) of Regulation (EC) No 2580/2001 on specific restrictive measures directed 
against certain persons and entities with a view to combating terrorism, and repealing Implementing Regulation (EU) No 1169/2012

- Council Implementing Regulation (EU) No 714/2013 of 25 July 2013 implementing Article 2(3) of Regulation (EC) No 2580/2001 on specific restrictive measures directed against certain persons and entities with a view to combating terrorism, and repealing Implementing Regulation (EU) No 1169/2012

- Council Decision 2014/72/CFSP of 10 February 2014 updating and amending the list of persons, groups and entities subject to Articles 2, 3 and 4 of Common Position 2001/931/CFSP on the application of specific measures to combat terrorism, and repealing Decision 2013/395/CFSP

- Council Implementing Regulation (EU) No 125/2014 of 10 February 2014 implementing Article 2(3) of Regulation (EC) No 2580/2001 on specific restrictive measures directed against certain persons and entities with a view to combating terrorism and repealing Implementing Regulation (EU) No 714/2013

- Council Implementing Regulation (EU) No 125/2014 of 10 February 2014 implementing Article 2(3) of Regulation (EC) No 2580/2001 on specific restrictive measures directed against certain persons and entities with a view to combating terrorism and repealing Implementing Regulation (EU) No 714/2013

- Council Decision 2014/483/CFSP of 22 July 2014 updating and amending the list of persons, groups and entities subject to Articles 2, 3 and 4 of Common Position 2001/931/CFSP on the application of specific measures to combat terrorism, and repealing Decision 2014/72/CFSP

- Council Implementing Regulation (EU) No 790/2014 of 22 July 2014 implementing Article 2(3) of Regulation (EC) No 2580/2001 on specific restrictive measures directed against certain persons and entities with a view to combatting terrorism, and repealing Implementing Regulation (EU) No 125/2014

- Council Implementing Regulation (EU) No 790/2014 of 22 July 2014 implementing Article 2(3) of Regulation (EC) No 2580/2001 on specific restrictive measures directed against certain persons and entities with a view to combatting terrorism, and repealing Implementing Regulation (EU) No 125/2014

- Council Decision (EU, Euratom) 2015/457 of 17 March 2015 repealing Decision 2007/124/EC, Euratom establishing for the period 2007 to 2013, as part of General Programme on Security and Safeguarding Liberties, the Specific Programme 'Prevention, Preparedness and Consequence Management of Terrorism and other Security related risks'

- Council Decision (CFSP) 2015/521 of 26 March 2015 updating and amending the list of persons, groups and entities subject to Articles 2, 3 and 4 of Common Position 2001/931/CFSP on the application of specific measures to combat terrorism, and repealing Decision 2014/483/CFSP 
- Council Implementing Regulation (EU) 2015/513 of 26 March 2015 implementing Article 2(3) of Regulation (EC) No 2580/2001 on specific restrictive measures directed against certain persons and entities with a view to combating terrorism and repealing Implementing Regulation (EU) No 790/2014

- Council Implementing Regulation (EU) 2015/513 of 26 March 2015 implementing Article 2(3) of Regulation (EC) No 2580/2001 on specific restrictive measures directed against certain persons and entities with a view to combating terrorism and repealing Implementing Regulation (EU) No 790/2014

- Directive (EU) 2015/849 of the European Parliament and of the Council of 20 May 2015 on the prevention of the use of the financial system for the purposes of money laundering or terrorist financing, amending Regulation (EU) No 648/2012 of the European Parliament and of the Council, and repealing Directive 2005/60/EC of the European Parliament and of the Council and Commission Directive 2006/70/EC (Text with EEA relevance)

- Council Implementing Regulation (EU) 2015/1325 of 31 July 2015 implementing Article 2(3) of Regulation (EC) No 2580/2001 on specific restrictive measures directed against certain persons and entities with a view to combating terrorism and repealing Implementing Regulation (EU) 2015/513

- Council Implementing Regulation (EU) 2015/1325 of 31 July 2015 implementing Article 2(3) of Regulation (EC) No 2580/2001 on specific restrictive measures directed against certain persons and entities with a view to combating terrorism and repealing Implementing Regulation (EU) 2015/513

- Council Decision (CFSP) 2015/1334 of 31 July 2015 updating the list of persons, groups and entities subject to Articles 2, 3 and 4 of Common Position 2001/931/CFSP on the application of specific measures to combat terrorism, and repealing Decision (CFSP) $2015 / 521$

- Council Decision (EU) 2015/1913 of 18 September 2015 on the signing, on behalf of the European Union, of the Council of Europe Convention on the Prevention of Terrorism (CETS No 196)

- Council Decision (EU) 2015/1914 of 18 September 2015 on the signing, on behalf of the European Union, of the Additional Protocol to the Council of Europe Convention on the Prevention of Terrorism (CETS No 196)

- Council Decision (CFSP) 2015/2430 of 21 December 2015 updating the list of persons, groups and entities subject to Articles 2, 3 and 4 of Common Position 2001/931/CFSP on the application of specific measures to combat terrorism, and repealing Decision (CFSP) 2015/1334

- Council Implementing Regulation (EU) 2015/2425 of 21 December 2015 implementing Article 2(3) of Regulation (EC) No 2580/2001 on specific restrictive measures directed against certain persons and entities with a view to combating terrorism, and repealing Implementing Regulation (EU) 2015/1325 
- Council Implementing Regulation (EU) 2015/2425 of 21 December 2015 implementing Article 2(3) of Regulation (EC) No 2580/2001 on specific restrictive measures directed against certain persons and entities with a view to combating terrorism, and repealing Implementing Regulation (EU) 2015/1325

- Council Decision (CFSP) 2016/628 of 21 April 2016 updating and amending the list of persons, groups and entities subject to Articles 2, 3 and 4 of Common Position 2001/931/CFSP on the application of specific measures to combat terrorism, and amending Decision (CFSP) 2015/2430

- Council Implementing Regulation (EU) 2016/620 of 21 April 2016 implementing Article 2(3) of Regulation (EC) No 2580/2001 on specific restrictive measures directed against certain persons and entities with a view to combating terrorism, and amending Implementing Regulation (EU) 2015/2425

- Council Implementing Regulation (EU) 2016/620 of 21 April 2016 implementing Article 2(3) of Regulation (EC) No 2580/2001 on specific restrictive measures directed against certain persons and entities with a view to combating terrorism, and amending Implementing Regulation (EU) 2015/2425

- Directive (EU) 2016/681 of the European Parliament and of the Council of 27 April 2016 on the use of passenger name record (PNR) data for the prevention, detection, investigation and prosecution of terrorist offences and serious crime

- Council Decision (CFSP) 2016/1136 of 12 July 2016 updating the list of persons, groups and entities subject to Articles 2, 3 and 4 of Common Position 2001/931/CFSP on the application of specific measures to combat terrorism, and repealing Decision (CFSP) $2015 / 2430$

- Council Implementing Regulation (EU) 2016/1127 of 12 July 2016 implementing Article 2(3) of Regulation (EC) No 2580/2001 on specific restrictive measures directed against certain persons and entities with a view to combating terrorism, and repealing Implementing Regulation (EU) 2015/2425

- Council Implementing Regulation (EU) 2016/1127 of 12 July 2016 implementing Article 2(3) of Regulation (EC) No 2580/2001 on specific restrictive measures directed against certain persons and entities with a view to combating terrorism, and repealing Implementing Regulation (EU) 2015/2425

- Council Regulation (EU) 2016/1710 of 27 September 2016 amending Regulation (EC) No 2580/2001 on specific restrictive measures directed against certain persons and entities with a view to combating terrorism

- Council Decision (CFSP) 2016/1711 of 27 September 2016 amending Common Position 2001/931/CFSP on the application of specific measures to combat terrorism

- Council Decision (CFSP) 2016/2384 of 22 December 2016 updating the list of persons, groups and entities subject to Articles 2, 3 and 4 of Common Position 2001/931/CFSP on the application of specific measures to combat terrorism, and amending Decision (CFSP) $2016 / 1136$ 
- Council Implementing Regulation (EU) 2016/2373 of 22 December 2016 implementing Article 2(3) of Regulation (EC) No 2580/2001 on specific restrictive measures directed against certain persons and entities with a view to combating terrorism, and amending Implementing Regulation (EU) 2016/1127

- Council Implementing Regulation (EU) 2016/2373 of 22 December 2016 implementing Article 2(3) of Regulation (EC) No 2580/2001 on specific restrictive measures directed against certain persons and entities with a view to combating terrorism, and amending Implementing Regulation (EU) 2016/1127

\section{ITALIAN MEASURES}

DECRETO DEL PRESIDENTE DELLA REPUBBLICA 14 marzo 2001, n. 318 Regolamento recante disciplina per l'assegnazione delle borse di studio in favore delle vittime del terrorismo e della criminalita', nonche' degli orfani e dei figli delle vittime del terrorismo. (GU n.182 del 7-82001 ) note: Entrata in vigore del decreto: 22-8-2001

http://www.normattiva.it/atto/caricaDettaglioAtto?atto.dataPubblicazioneGazzetta=2001-0807\&atto.codiceRedazionale $=001 \mathrm{G} 0380$

English: DECISION OF THE PRESIDENT OF THE REPUBLIC of 14 March 2001, no. 318 Regulation laying down discipline for granting scholarships in favor of victims of terrorism and crime, as well as of orphans and children of victims of terrorism. (OJ No 182 of 7-8-2001) Notes: Entry into force of the Decree: 22-8-2001

DECRETO-LEGGE 12 ottobre 2001, n. 369 Misure urgenti per reprimere e contrastare il finanziamento del terrorismo internazionale. (GU n.240 del 15-10-2001 ) note: Entrata in vigore del decreto-legge: 15-10-2001. Decreto-Legge convertito con modificazioni dalla L. 14 dicembre 2001, n. 431 (in G.U. 14/12/2001, n.290)

http://www.normattiva.it/atto/caricaDettaglioAtto?atto.dataPubblicazioneGazzetta=2001-1015\&atto.codiceRedazionale $=001 \mathrm{G} 0434$

English: DECREE-LAW 12 October 2001, no. 369 Urgent measures to suppress and counter the financing of international terrorism. (OJ No.240 of 15-10-2001) Notes: Entry into force of the Decree-Law: 15-10-2001. Decree-Law converted with amendments from the Law of 14 December 2001, no. 431 (in G.U. 14/12/2001, n. 290).

DECRETO-LEGGE 18 ottobre 2001, n. 374

Disposizioni urgenti per contrastare il terrorismo internazionale. (GU n.244 del 19-10-2001 ) 
note: Entrata in vigore del decreto-legge: 19-10-2001. Decreto-Legge convertito con modificazioni dalla L. 15 dicembre 2001, n. 438 (in G.U. 18/12/2001, n.293).

http://www.normattiva.it/atto/caricaDettaglioAtto?

atto.dataPubblicazioneGazzetta $=2001-10-19 \&$ atto. codiceRedazionale $=001 \mathrm{G} 0440$

English: DECREE-LAW 18 October 2001, no. 374

Urgent provisions to counter international terrorism. (OJ No. 244, 19-10-2001)

notes: Entry into force of the decree-law: 19-10-2001. Decree-Law converted with modifications by L. Dec. 15, 2001, no. 438 (in G.U. 18/12/2001, n. 293).

LEGGE 14 dicembre 2001, n. 431

Conversione in legge, con modificazioni, del decreto-legge 12 ottobre 2001, n. 369, recante misure urgenti per reprimere e contrastare il finanziamento del terrorismo internazionale. (GU n.290 del 14-12-2001)

http:/www.normattiva.it/atto/caricaDettaglioAtto?atto.dataPubblicazioneGazzetta=2001-1214\&atto.codiceRedazionale $=001 \mathrm{G} 0493$

English: LAW 14 December 2001, no. 431

Conversion into law, with modifications, of Decree-Law no. 369, urgent measures to suppress and counter the financing of international terrorism. (OJ No 290, 14-12-2001)

LEGGE 15 dicembre 2001, n. 438

Conversione in legge, con modificazioni, del decreto-legge 18 ottobre 2001, n. 374, recante disposizioni urgenti per contrastare il terrorismo internazionale. (GU n.293 del 18-12-2001)

http:/www.normattiva.it/atto/caricaDettaglioAtto?atto.dataPubblicazioneGazzetta=2001-1218\&atto.codiceRedazionale $=001 \mathrm{G} 0496 \&$ atto.articolo.numero $=1 \&$ atto. articolo.tipoArticolo $=0$

English: LAW 15 December 2001, no. 438

Conversion into law, with modifications, of the Decree-Law of 18 October 2001, no. 374, containing urgent provisions to counter international terrorism. (OJ No 293, 18-12-2001)

LEGGE 14 gennaio 2003, n. 7

Ratifica ed esecuzione della Convenzione internazionale per la repressione del finanziamento del terrorismo, fatta a New York il 9 dicembre 1999, e norme di adeguamento dell'ordinamento interno. (GU n.21 del 27-1-2003)

http://gazzette.comune.jesi.an.it/2003/21/1.htm 
LAW 14 January 2003, no. 7

Ratification and enforcement of the International Convention for the Suppression of the Financing of Terrorism, done at New York on 9 December 1999, and rules for adjusting the internal order. (OJ No 21 of 27-1-2003)

DECRETO-LEGGE 4 febbraio 2003, n. 13

Disposizioni urgenti in favore delle vittime del terrorismo e della criminalita' organizzata. (GU n.29 del 5-2-2003 ) note: Entrata in vigore del decreto: 6-2-2003.

Decreto-Legge convertito con modificazioni dalla L.2 aprile 2003, n. 56 (in G.U. 05/04/2003, n.80).

http://gazzette.comune.jesi.an.it/2003/80/5.htm

DECREE-LAW 4 February 2003, no. 13

Urgent provisions in favor of victims of terrorism and organized crime. (OJ No 29 of 5-2-2003) notes:

Entry into force of the Decree: 6-2-2003.

Decree-Law converted with amendments from April 2, 2003, no. 56 (in G.U. 05/04/2003, n. 80).

LEGGE 2 aprile 2003, n. 56

Conversione in legge, con modificazioni, del decreto-legge 4 febbraio 2003, n. 13, recante disposizioni urgenti in favore delle vittime del terrorismo e della criminalita' organizzata. (GU n.80 del 5-4-2003)

LAW No. 2 April 2003, no. 56

Conversion into law, with modifications, of the decree-law of 4 February 2003, no. 13, containing urgent provisions in favor of victims of terrorism and organized crime. (OJ No 80 of 5-4-2003)

LEGGE 3 agosto 2004, n. 206

Nuove norme in favore delle vittime del terrorismo e delle stragi di tale matrice. (GU n.187 del 11-8-2004)

note: Entrata in vigore del provvedimento: 26/8/2004

http://gazzette.comune.jesi.an.it/2004/187/2.htm

Law no. 3, August 2004, no. 206

New rules in favor of victims of terrorism and the massacre of this matrix. (OJ No 187 of 11-82004) notes: Entry into force of the measure: 26/8/2004 
DECRETO-LEGGE 27 luglio 2005, n. 144

Misure urgenti per il contrasto del terrorismo internazionale. (GU n.173 del 27-07-2005)

http://www.camera.it/parlam/leggi/decreti/05144d.htm

DECREE-LAW 27 July 2005, no. 144

Urgent measures to counter international terrorism. (OJ No 173 of 27-07-2005)

LEGGE 31 luglio 2005, n. 155

Conversione in legge, con modificazioni, del decreto-legge 27 luglio 2005, n. 144, recante misure urgenti per il contrasto del terrorismo internazionale. (GU n.177 del 01-08-2005) http://gazzette.comune.jesi.an.it/2005/177/3.htm

LAW 31 July 2005, no. 155

Conversion into law, with modifications, of Decree-Law no. 144, urging urgent measures to counter international terrorism. (OJ No.177 of 01-08-2005)

LEGGE 10 ottobre 2005, n. 207

Conferimento della Croce d'onore alle vittime di atti di terrorismo o di atti ostili impegnate in operazioni militari e civili all'estero. (GU n.239 del 13-10-2005 )

http://www.camera.it/parlam/leggi/052071.htm

LAW 10 October 2005, no. 207

Award of the Cross of Honor to victims of acts of terrorism or of acts of hostility engaged in military and civilian operations abroad. (OJ No. 239, 13-10-2005)

DECRETO DEL PRESIDENTE DELLA REPUBBLICA 7 luglio 2006, n. 243

Regolamento concernente termini e modalita' di corresponsione delle provvidenze alle vittime del dovere ed ai soggetti equiparati, ai fini della progressiva estensione dei benefici gia' previsti in favore delle vittime della criminalita' e del terrorismo, a norma dell'articolo 1, comma 565, della legge 23 dicembre 2005, n. 266. (GU n.183 del 08-08-2006 )

https://it.wikisource.org/wiki/D.P.R._7_luglio_2006,_n._243_-

_Provvedimenti_alle_vittime_del_dovere

DECISION OF THE PRESIDENT OF THE REPUBLIC of 7 July 2006, no. 243

Regulation on the terms and modalities for the provision of assistance to victims of duty and persons treated as such, with a view to the progressive extension of benefits already provided for 
victims of crime and terrorism pursuant to Article 1, paragraph 565, of the law of 23 December 2005, no. 266. (OJ No.183 of 08-08-2006)

LEGGE 4 maggio 2007, n. 56

Istituzione del «Giorno della memoria» dedicato alle vittime del terrorismo e delle stragi di tale matrice. (GU n.103 del 05-05-2007 )

http://www.parlamento.it/parlam/leggi/070561.htm

LAW 4 May 2007, no. 56

Establishment of the "Day of Memory" dedicated to the victims of terrorism and the massacres of this matrix. (OJ No.103 of 05-05-2007)

DECRETO LEGISLATIVO 22 giugno 2007, n. 109

Misure per prevenire, contrastare e reprimere il finanziamento del terrorismo e l'attivita' dei Paesi che minacciano la pace e la sicurezza internazionale, in attuazione della direttiva 2005/60/CE. (GU n.172 del 26-07-2007)

http://www.parlamento.it/parlam/leggi/deleghe/07109dl.htm

LEGISLATIVE DECREE 22 June 2007, no. 109

Measures to prevent, counteract and suppress the financing of terrorism and the activities of countries threatening international peace and security in implementation of Directive 2005/60 / EC. (OJ No 172 of 26-07-2007)

DECRETO LEGISLATIVO 21 novembre 2007, n. 231

Attuazione della direttiva 2005/60/CE concernente la prevenzione dell'utilizzo del sistema finanziario a scopo di riciclaggio dei proventi di attivita' criminose e di finanziamento del terrorismo nonche' della direttiva 2006/70/CE che ne reca misure di esecuzione. (GU n.290 del 14-12-2007 - Suppl. Ordinario n. 268 )

http:/www.camera.it/parlam/leggi/deleghe/testi/07231dl.htm

LEGISLATIVE DECREE 21 November 2007, no. 231

Implementation of Directive 2005/60 / EC on the prevention of the use of the financial system for the purpose of money laundering and the financing of terrorism and of Directive 2006/70 / EC implementing implementing measures. (OJ No 290, 14-12-2007 - Ordinary Supplement No 268)

DECRETO-LEGGE 29 dicembre 2007, n. 249 
Misure urgenti in materia di espulsioni e di allontanamenti per terrorismo e per motivi imperativi di pubblica sicurezza. (GU n.1 del 02-01-2008)

http://www.camera.it/parlam/leggi/decreti/07249d.htm

DECREE-LAW 29 December 2007, no. 249

Urgent measures on extradition and expulsion for terrorism and for imperative reasons of public security. (OJ No. 1 of 02-01-2008)

DECRETO LEGISLATIVO 11 maggio 2009, n. 54

Modifiche ed integrazioni al decreto legislativo 22 giugno 2007, n. 109, recante attuazione della direttiva 2005/60/CE, concernente misure per prevenire, contrastare e reprimere il finanziamento al terrorismo e l'attivita' di Paesi che minacciano la pace e la sicurezza internazionale. (09G0063) (GU n.122 del 28-05-2009)

http:/www.camera.it/parlam/leggi/deleghe/testi/09054dl.htm

LEGISLATIVE DECREE 11 May 2009, no. 54

Amendments and additions to Legislative Decree 22 June 2007, no. 109 implementing Directive 2005/60 / EC on measures to prevent, counteract and suppress financing for terrorism and the activities of countries threatening international peace and security. (09G0063) (OJ No.122 of 28 May 2009)

DECRETO DEL PRESIDENTE DELLA REPUBBLICA 5 maggio 2009, n. 58 Regolamento recante modifiche ed integrazioni al decreto del Presidente della Repubblica n. 318 del 2001 per l'assegnazione delle borse di studio in favore delle vittime del terrorismo e della criminalita' organizzata, delle vittime del dovere, nonche' dei loro superstiti. (09G0066) (GU n.126 del 03-06-2009)

http://www.levittimedeldovereditalia.it/files/DECRETO-DEL-PRESIDENTE-DELLAREPUBBLICA--5--MAGGIO-2009-N-58.pdf

DECISION OF THE PRESIDENT OF THE REPUBLIC of 5 May 2009, no. 58 Regulation amending and supplementing the decree of the President of the Republic no. 318 of 2001 for granting scholarships to victims of terrorism and organized crime, victims of duty and their survivors. (09G0066) (OJ No.126 of 03-06-2009)

LEGGE 30 giugno 2009, n. 85

Adesione della Repubblica italiana al Trattato concluso il 27 maggio 2005 tra il Regno del Belgio, la Repubblica federale di Germania, il Regno di Spagna, la Repubblica francese, il 
Granducato di Lussemburgo, il Regno dei Paesi Bassi e la Repubblica d'Austria, relativo all'approfondimento della cooperazione transfrontaliera, in particolare allo scopo di contrastare il terrorismo, la criminalita' transfrontaliera e la migrazione illegale (Trattato di Prum). Istituzione della banca dati nazionale del DNA e del laboratorio centrale per la banca dati nazionale del DNA. Delega al Governo per l'istituzione dei ruoli tecnici del Corpo di polizia penitenziaria. Modifiche al codice di procedura penale in materia di accertamenti tecnici idonei ad incidere sulla liberta' personale. (09G0092) (GU n.160 del 13-07-2009 - Suppl. Ordinario n. 108 )

http://www.parlamento.it/parlam/leggi/090851.htm

LAW 30 June 2009, no. 85

Accession of the Italian Republic to the Treaty of 27 May 2005 between the Kingdom of Belgium, the Federal Republic of Germany, the Kingdom of Spain, the French Republic, the Grand Duchy of Luxembourg, the Kingdom of the Netherlands and the Republic of to the deepening of cross-border cooperation, in particular with a view to countering terrorism, crossborder crime and illegal migration (the Prum Treaty). Establishment of the national DNA database and of the central laboratory for the national DNA database. Delegation to the Government for the institution of the technical roles of the Prison Police Corps. Amendments to the Code of Criminal Procedure relating to technical assessments capable of affecting personal freedom. (09G0092) (OJ No.160 of 13 July 2009 - Ordinary Supplement No 108)

DECRETO LEGISLATIVO 25 settembre 2009, n. 151

Disposizioni integrative e correttive del decreto legislativo 21 novembre 2007, n. 231, recante attuazione della direttiva 2005/60/CE concernente la prevenzione dell'utilizzo del sistema finanziario a scopo di riciclaggio dei proventi di attivita' criminose e di finanziamento del terrorismo, nonche' della direttiva 2006/70/CE che reca misure di esecuzione. (09G0163) (GU n.256 del 03-11-2009)

http://www.camera.it/parlam/leggi/deleghe/09151dl.htm

LEGISLATIVE DECREE 25 September 2009, no. 151

Supplementary and corrective provisions of Legislative Decree no. 231 implementing Directive 2005/60 / EC on the prevention of the use of the financial system for the purpose of money laundering and the financing of terrorism as well as of Directive 2006/70 / EC implementing implementing measures . (09G0163) (OJ No.256 of 03-11-2009)

DECRETO DEL PRESIDENTE DELLA REPUBBLICA 30 ottobre 2009, n. 181 ((Regolamento recante i criteri medico-legali per l'accertamento e la determinazione dell' invalidita' e del danno biologico e morale a carico delle vittime del terrorismo e delle stragi di tale matrice, a norma dell'articolo 6 della legge 3 agosto 2004, n. 206.)) (09G0186) (GU n.292 
del 16-12-2009)

http://www.normattiva.it/uri-res/N2Ls?urn:nir:stato:presidente.repubblica:decreto:2009-10$30 ; 181$ !vig=

DECISION OF THE PRESIDENT OF THE REPUBLIC of 30 October 2009, no. 181 ((Regulation laying down the medical and legal criteria for the determination and determination of the invalidity and the biological and moral damage to the victims of terrorism and the massacres of that matrix, pursuant to Article 6 of the Law of 3 August 2004, No. 206.)) (09G0186) (OJ No.292 of 16-12-2009)

LEGGE 21 novembre 2014, n. 179

Ratifica ed esecuzione dell'Accordo di cooperazione fra il Governo della Repubblica italiana ed il Governo della Repubblica di Estonia sulla lotta contro la criminalita' organizzata, il terrorismo ed il traffico illecito di droga, fatto a Tallinn l'8 settembre 2009. (14G00192) (GU n.287 del 1112-2014)

http://www.normattiva.it/uri-res/N2Ls?urn:nir:stato:legge:2014;179

LAW 21 November 2014, n. 179

Ratification and enforcement of the Cooperation Agreement between the Government of the Italian Republic and the Government of the Republic of Estonia on the fight against organized crime, terrorism and illicit drug trafficking, done at Tallinn on 8 September 2009. (14G00192) (OJ No 287 of 11-12-2014)

LEGGE 12 gennaio 2015, n. 5

Ratifica ed esecuzione dell'Accordo di cooperazione tra il Governo della Repubblica italiana ed il Governo della Repubblica di Turchia sulla lotta ai reati gravi, in particolare contro il terrorismo e la criminalita' organizzata, fatto a Roma l'8 maggio 2012. (15G00013) (GU n.23 del 29-012015 )

http://www.normattiva.it/uri-res/N2Ls?urn:nir:stato:legge:2015;5

LAW 12 January 2015, n. 5

Ratification and enforcement of the Cooperation Agreement between the Government of the Italian Republic and the Government of the Republic of Turkey on the fight against serious crimes, in particular against terrorism and organized crime, done in Rome on 8 May 2012. (15G00013) (OJ No 23 of 29.01.2015)

DECRETO-LEGGE 18 febbraio 2015, n. 7 
Misure urgenti per il contrasto del terrorismo, anche di matrice internazionale, nonche' proroga delle missioni internazionali delle Forze armate e di polizia, iniziative di cooperazione allo sviluppo e sostegno ai processi di ricostruzione e partecipazione alle iniziative delle Organizzazioni internazionali per il consolidamento dei processi di pace e di stabilizzazione. (15G00019) (GU n.41 del 19-02-2015)

http://www.normattiva.it/uri-res/N2Ls?urn:nir:stato:decreto.legge:2015;7

\section{DECREE-LAW 18 February 2015, n. 7}

Urgent measures to counter terrorism, including an international matrix, as well as the extension of the international missions and police missions, development co-operation initiatives and support for reconstruction processes and participation in international organizations' initiatives to consolidate peace and stabilization. (15G00019) (OJ No 41 of 19 February 2015)

LEGGE 17 aprile 2015, n. 43

Conversione in legge, con modificazioni, del decreto-legge 18 febbraio 2015, n. 7, recante misure urgenti per il contrasto del terrorismo, anche di matrice internazionale, nonche' proroga delle missioni internazionali delle Forze armate e di polizia, iniziative di cooperazione allo sviluppo e sostegno ai processi di ricostruzione e partecipazione alle iniziative delle Organizzazioni internazionali per il consolidamento dei processi di pace e di stabilizzazione. (15G00060) (GU n.91 del 20-04-2015)

\section{LAW 17 April 2015, n. 43}

Conversion into law, with modifications, of the decree-law of February 18, 2015, n. 7 on urgent measures to counter terrorism, including an international matrix, as well as the extension of the international missions and police missions, development co-operation initiatives and support for reconstruction processes and participation in the initiatives of international organizations for consolidation of peace and stabilization processes. (15G00060) (OJ No 91 of 20-04-2015)

LEGGE 7 dicembre 2015, n. 216

Ratifica ed esecuzione dell'Accordo fra il Governo della Repubblica italiana ed il Governo della Repubblica del Kazakhstan di cooperazione nel contrasto alla criminalita' organizzata, al traffico illecito di sostanze stupefacenti e psicotrope, di precursori e sostanze chimiche impiegate per la loro produzione, al terrorismo e ad altre forme di criminalita', fatto a Roma il 5 novembre 2009. (15G00229) (GU n.5 del 08-01-2016)

http://www.normattiva.it/uri-res/N2Ls?urn:nir:stato:legge:2015;216

LAW 7 December 2015, n. 216

Ratification and enforcement of the Agreement between the Government of the Italian Republic 
and the Government of the Republic of Kazakhstan on cooperation in the fight against organized crime, illicit trafficking in narcotic drugs and psychotropic substances, precursors and chemical substances used for their production, terrorism and other forms of crime, done at Rome on 5 November 2009. (15G00229) (OJ No 5 of 08.01.2016)

LEGGE 28 luglio 2016, n. 153

Norme per il contrasto al terrorismo, nonche' ratifica ed esecuzione: a) della Convenzione del Consiglio d'Europa per la prevenzione del terrorismo, fatta a Varsavia il 16 maggio 2005; b) della Convenzione internazionale per la soppressione di atti di terrorismo nucleare, fatta a New York il 14 settembre 2005; c) del Protocollo di Emendamento alla Convenzione europea per la repressione del terrorismo, fatto a Strasburgo il 15 maggio 2003; d) della Convenzione del Consiglio d'Europa sul riciclaggio, la ricerca, il sequestro e la confisca dei proventi di reato e sul finanziamento del terrorismo, fatta a Varsavia il 16 maggio 2005; e) del Protocollo addizionale alla Convenzione del Consiglio d'Europa per la prevenzione del terrorismo, fatto a Riga il 22 ottobre 2015. (16G00165) (GU n.185 del 09-08-2016 - Suppl. Ordinario n. 31 )

LAW 28 July 2016, no. 153

Standards for countering terrorism, as well as ratification and execution: a) of the Council of Europe Convention for the Prevention of Terrorism, done in Warsaw on 16 May 2005; (b) of the International Convention for the Suppression of Nuclear Terrorism, done at New York on 14 September 2005; (c) of the Protocol to the European Convention for the Suppression of Terrorism, done at Strasbourg on 15 May 2003; (d) of the Council of Europe Convention on Laundering, Search, Seizure and Confiscation of proceeds of crime and the financing of terrorism, done at Warsaw on 16 May 2005; (e) of the Additional Protocol to the Council of Europe Convention for the Prevention of Terrorism, done at Riga on 22 October 2015. (16G00165) (OJ No.185 of 09-08-2016 - Ordinary Supplement No 31) 
ANNEX B: PILLARS OF THE EU COUNTERTERRORISM STRATEGY 2005

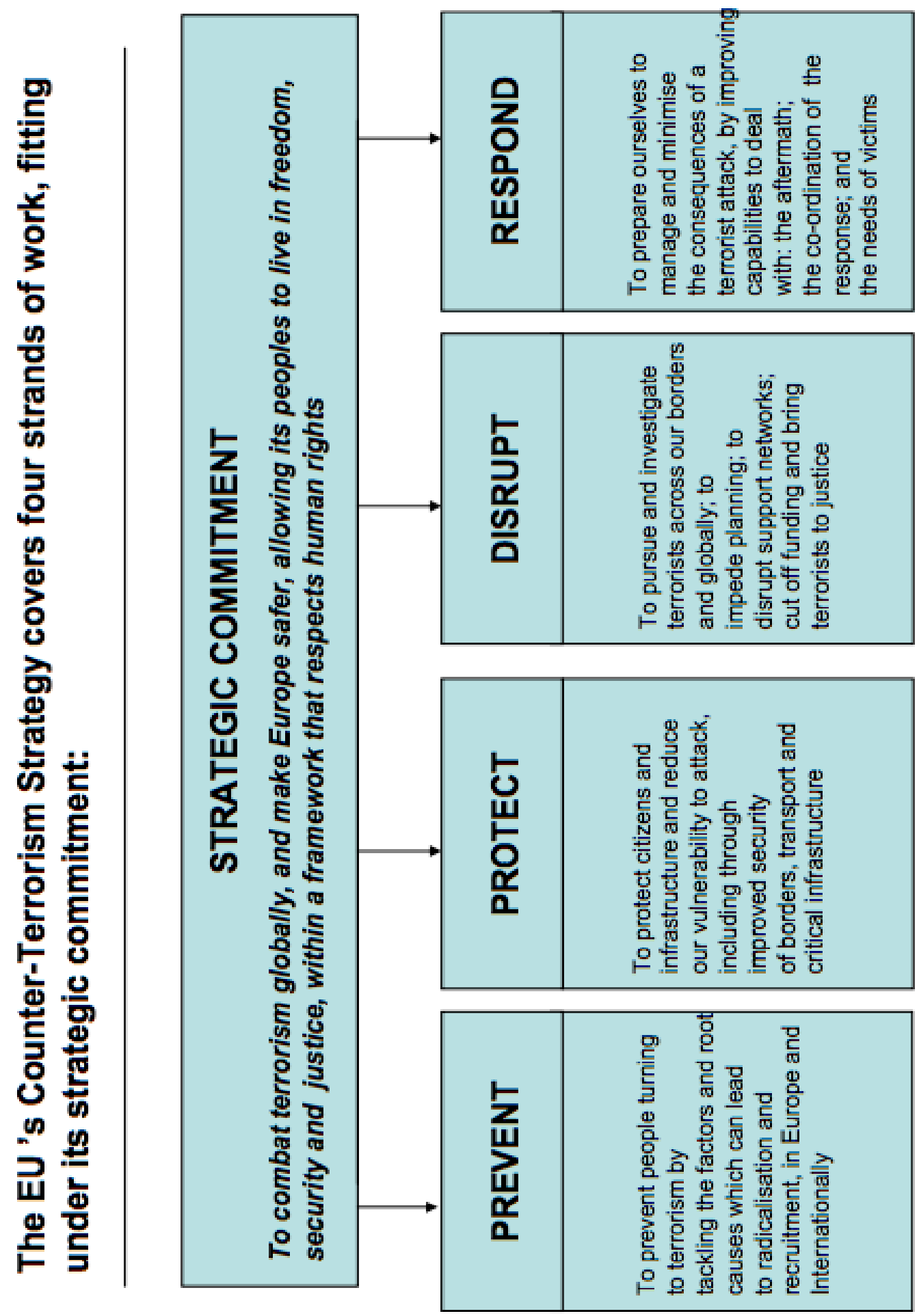




\section{ANNEX C: COUNCIL FRAMEWORK DECISION 2002/475/JHA ON COMBATTING TERRORISM}

Council Framework Decision

of 13 June 2002

on combating terrorism

(2002/475/JHA)

\section{THE COUNCIL OF THE EUROPEAN UNION,}

Having regard to the Treaty establishing the European Union, and in particular Article 29, Article 31(e) and Article 34(2)(b) thereof,

Having regard to the proposal from the Commission(1),

Having regard to the opinion of the European Parliament(2),

Whereas:

(1) The European Union is founded on the universal values of human dignity, liberty, equality and solidarity, respect for human rights and fundamental freedoms. It is based on the principle of democracy and the principle of the rule of law, principles which are common to the Member States.

(2) Terrorism constitutes one of the most serious violations of those principles. The La Gomera Declaration adopted at the informal Council meeting on 14 October 1995 affirmed that terrorism constitutes a threat to democracy, to the free exercise of human rights and to economic and social development.

(3) All or some Member States are party to a number of conventions relating to terrorism. The Council of Europe Convention of 27 January 1977 on the Suppression of Terrorism does not regard terrorist offences as political offences or as offences connected with political offences or as offences inspired by political motives. The United Nations has adopted the Convention for the suppression of terrorist bombings of 15 December 1997 and the Convention for the suppression of financing terrorism of 9 December 1999. A draft global Convention against terrorism is currently being negotiated within the United Nations.

(4) At European Union level, on 3 December 1998 the Council adopted the Action Plan of the Council and the Commission on how best to implement the provisions of the Treaty of Amsterdam on an area of freedom, security and justice(3). Account should also be taken of the Council Conclusions of 20 September 2001 and of the Extraordinary European Council plan of action to combat terrorism of 21 September 2001. Terrorism was referred to in the conclusions of the Tampere European Council of 15 and 16 October 1999, and of the Santa María da Feira European Council of 19 and 20 June 2000. It was also mentioned in the Commission communication to the Council and the European Parliament on the biannual update of the scoreboard to review progress on the creation of an area of "freedom, security and justice" in the European Union (second half 
of 2000). Furthermore, on 5 September 2001 the European Parliament adopted a recommendation on the role of the European Union in combating terrorism. It should, moreover, be recalled that on 30 July 1996 twenty-five measures to fight against terrorism were advocated by the leading industrialised countries (G7) and Russia meeting in Paris.

(5) The European Union has adopted numerous specific measures having an impact on terrorism and organised crime, such as the Council Decision of 3 December 1998 instructing Europol to deal with crimes committed or likely to be committed in the course of terrorist activities against life, limb, personal freedom or property(4); Council Joint Action 96/610/JHA of 15 October 1996 concerning the creation and maintenance of a Directory of specialised counter-terrorist competences, skills and expertise to facilitate counter-terrorism cooperation between the Member States of the European Union(5); Council Joint Action 98/428/JHA of 29 June 1998 on the creation of a European Judicial Network(6), with responsibilities in terrorist offences, in particular Article 2; Council Joint Action 98/733/JHA of 21 December 1998 on making it a criminal offence to participate in a criminal organisation in the Member States of the European Union(7); and the Council Recommendation of 9 December 1999 on cooperation in combating the financing of terrorist groups(8).

(6) The definition of terrorist offences should be approximated in all Member States, including those offences relating to terrorist groups. Furthermore, penalties and sanctions should be provided for natural and legal persons having committed or being liable for such offences, which reflect the seriousness of such offences.

(7) Jurisdictional rules should be established to ensure that the terrorist offence may be effectively prosecuted.

(8) Victims of terrorist offences are vulnerable, and therefore specific measures are necessary with regard to them.

(9) Given that the objectives of the proposed action cannot be sufficiently achieved by the Member States unilaterally, and can therefore, because of the need for reciprocity, be better achieved at the level of the Union, the Union may adopt measures, in accordance with the principle of subsidiarity. In accordance with the principle of proportionality, this Framework Decision does not go beyond what is necessary in order to achieve those objectives.

(10) This Framework Decision respects fundamental rights as guaranteed by the European Convention for the Protection of Human Rights and Fundamental Freedoms and as they emerge from the constitutional traditions common to the Member States as principles of Community law. The Union observes the principles recognised by Article 6(2) of the Treaty on European Union and reflected in the Charter of Fundamental Rights of the European Union, notably Chapter VI thereof. Nothing in this Framework Decision may be interpreted as being intended to reduce or restrict fundamental rights or freedoms such as the right to strike, freedom of assembly, of association or of expression, including the right of everyone to form and to join trade unions with others for the protection of his or her interests and the related right to demonstrate. 
(11) Actions by armed forces during periods of armed conflict, which are governed by international humanitarian law within the meaning of these terms under that law, and, inasmuch as they are governed by other rules of international law, actions by the armed forces of a State in the exercise of their official duties are not governed by this Framework Decision,

\section{HAS ADOPTED THIS FRAMEWORK DECISION:}

\section{Article 1}

Terrorist offences and fundamental rights and principles

1. Each Member State shall take the necessary measures to ensure that the intentional acts referred to below in points (a) to (i), as defined as offences under national law, which, given their nature or context, may seriously damage a country or an international organisation where committed with the aim of:

- seriously intimidating a population, or

- unduly compelling a Government or international organisation to perform or abstain from performing any act, or

- seriously destabilising or destroying the fundamental political, constitutional, economic or social structures of a country or an international organisation,

shall be deemed to be terrorist offences:

(a) attacks upon a person's life which may cause death;

(b) attacks upon the physical integrity of a person;

(c) kidnapping or hostage taking;

(d) causing extensive destruction to a Government or public facility, a transport system, an infrastructure facility, including an information system, a fixed platform located on the continental shelf, a public place or private property likely to endanger human life or result in major economic loss;

(e) seizure of aircraft, ships or other means of public or goods transport;

(f) manufacture, possession, acquisition, transport, supply or use of weapons, explosives or of nuclear, biological or chemical weapons, as well as research into, and development of, biological and chemical weapons;

(g) release of dangerous substances, or causing fires, floods or explosions the effect of which is to endanger human life;

(h) interfering with or disrupting the supply of water, power or any other fundamental natural resource the effect of which is to endanger human life;

(i) threatening to commit any of the acts listed in (a) to (h).

2. This Framework Decision shall not have the effect of altering the obligation to respect fundamental rights and fundamental legal principles as enshrined in Article 6 of the Treaty on European Union. 
Article 2

Offences relating to a terrorist group

1. For the purposes of this Framework Decision, "terrorist group" shall mean: a structured group of more than two persons, established over a period of time and acting in concert to commit terrorist offences. "Structured group" shall mean a group that is not randomly formed for the immediate commission of an offence and that does not need to have formally defined roles for its members, continuity of its membership or a developed structure.

2. Each Member State shall take the necessary measures to ensure that the following intentional acts are punishable:

(a) directing a terrorist group;

(b) participating in the activities of a terrorist group, including by supplying information or material resources, or by funding its activities in any way, with knowledge of the fact that such participation will contribute to the criminal activities of the terrorist group.

Article 3

Offences linked to terrorist activities

Each Member State shall take the necessary measures to ensure that terrorist-linked offences include the following acts:

(a) aggravated theft with a view to committing one of the acts listed in Article 1(1);

(b) extortion with a view to the perpetration of one of the acts listed in Article 1(1);

(c) drawing up false administrative documents with a view to committing one of the acts listed in Article 1(1)(a) to (h) and Article 2(2)(b).

Article 4

Inciting, aiding or abetting, and attempting

1. Each Member State shall take the necessary measures to ensure that inciting or aiding or abetting an offence referred to in Article 1(1), Articles 2 or 3 is made punishable.

2. Each Member State shall take the necessary measures to ensure that attempting to commit an offence referred to in Article 1(1) and Article 3, with the exception of possession as provided for in Article 1(1)(f) and the offence referred to in Article 1(1)(i), is made punishable.

Article 5

Penalties

1. Each Member State shall take the necessary measures to ensure that the offences referred to in Articles 1 to 4 are punishable by effective, proportionate and dissuasive criminal penalties, which may entail extradition. 
2. Each Member State shall take the necessary measures to ensure that the terrorist offences referred to in Article 1(1) and offences referred to in Article 4, inasmuch as they relate to terrorist offences, are punishable by custodial sentences heavier than those imposable under national law for such offences in the absence of the special intent required pursuant to Article 1(1), save where the sentences imposable are already the maximum possible sentences under national law.

3. Each Member State shall take the necessary measures to ensure that offences listed in Article 2 are punishable by custodial sentences, with a maximum sentence of not less than fifteen years for the offence referred to in Article 2(2)(a), and for the offences listed in Article 2(2)(b) a maximum sentence of not less than eight years. In so far as the offence referred to in Article 2(2)(a) refers only to the act in Article 1(1)(i), the maximum sentence shall not be less than eight years.

Article 6

Particular circumstances

Each Member State may take the necessary measures to ensure that the penalties referred to in Article 5 may be reduced if the offender:

(a) renounces terrorist activity, and

(b) provides the administrative or judicial authorities with information which they would not otherwise have been able to obtain, helping them to:

(i) prevent or mitigate the effects of the offence;

(ii) identify or bring to justice the other offenders;

(iii) find evidence; or

(iv) prevent further offences referred to in Articles 1 to 4.

Article 7

Liability of legal persons

1. Each Member State shall take the necessary measures to ensure that legal persons can be held liable for any of the offences referred to in Articles 1 to 4 committed for their benefit by any person, acting either individually or as part of an organ of the legal person, who has a leading position within the legal person, based on one of the following:

(a) a power of representation of the legal person;

(b) an authority to take decisions on behalf of the legal person;

(c) an authority to exercise control within the legal person.

2. Apart from the cases provided for in paragraph 1, each Member State shall take the necessary measures to ensure that legal persons can be held liable where the lack of supervision or control by a person referred to in paragraph 1 has made possible the 
commission of any of the offences referred to in Articles 1 to 4 for the benefit of that legal person by a person under its authority.

3. Liability of legal persons under paragraphs 1 and 2 shall not exclude criminal proceedings against natural persons who are perpetrators, instigators or accessories in any of the offences referred to in Articles 1 to 4.

Article 8

Penalties for legal persons

Each Member State shall take the necessary measures to ensure that a legal person held liable pursuant to Article 7 is punishable by effective, proportionate and dissuasive penalties, which shall include criminal or non-criminal fines and may include other penalties, such as:

(a) exclusion from entitlement to public benefits or aid;

(b) temporary or permanent disqualification from the practice of commercial activities;

(c) placing under judicial supervision;

(d) a judicial winding-up order;

(e) temporary or permanent closure of establishments which have been used for committing the offence.

Article 9

Jurisdiction and prosecution

1. Each Member State shall take the necessary measures to establish its jurisdiction over the offences referred to in Articles 1 to 4 where:

(a) the offence is committed in whole or in part in its territory. Each Member State may extend its jurisdiction if the offence is committed in the territory of a Member State;

(b) the offence is committed on board a vessel flying its flag or an aircraft registered there;

(c) the offender is one of its nationals or residents;

(d) the offence is committed for the benefit of a legal person established in its territory;

(e) the offence is committed against the institutions or people of the Member State in question or against an institution of the European Union or a body set up in accordance with the Treaty establishing the European Community or the Treaty on European Union and based in that Member State.

2. When an offence falls within the jurisdiction of more than one Member State and when any of the States concerned can validly prosecute on the basis of the same facts, the Member States concerned shall cooperate in order to decide which of them will prosecute the offenders with the aim, if possible, of centralising proceedings in a single Member State. To this end, the Member States may have recourse to any body or mechanism established within the European Union in order to facilitate cooperation between their 
judicial authorities and the coordination of their action. Sequential account shall be taken of the following factors:

- the Member State shall be that in the territory of which the acts were committed,

- the Member State shall be that of which the perpetrator is a national or resident,

- the Member State shall be the Member State of origin of the victims,

- the Member State shall be that in the territory of which the perpetrator was found.

3. Each Member State shall take the necessary measures also to establish its jurisdiction over the offences referred to in Articles 1 to 4 in cases where it refuses to hand over or extradite a person suspected or convicted of such an offence to another Member State or to a third country.

4. Each Member State shall ensure that its jurisdiction covers cases in which any of the offences referred to in Articles 2 and 4 has been committed in whole or in part within its territory, wherever the terrorist group is based or pursues its criminal activities.

5. This Article shall not exclude the exercise of jurisdiction in criminal matters as laid down by a Member State in accordance with its national legislation.

Article 10

Protection of, and assistance to, victims

1. Member States shall ensure that investigations into, or prosecution of, offences covered by this Framework Decision are not dependent on a report or accusation made by a person subjected to the offence, at least if the acts were committed on the territory of the Member State.

2. In addition to the measures laid down in the Council Framework Decision 2001/220/JHA of 15 March 2001 on the standing of victims in criminal proceedings(9), each Member State shall, if necessary, take all measures possible to ensure appropriate assistance for victims' families.

Article 11

Implementation and reports

1. Member States shall take the necessary measures to comply with this Framework Decision by 31 December 2002.

2. By 31 December 2002, Member States shall forward to the General Secretariat of the Council and to the Commission the text of the provisions transposing into their national law the obligations imposed on them under this Framework Decision. On the basis of a report drawn up from that information and a report from the Commission, the Council shall assess, by 31 December 2003, whether Member States have taken the necessary measures to comply with this Framework Decision.

3. The Commission report shall specify, in particular, transposition into the criminal law of the Member States of the obligation referred to in Article 5(2). 
Article 12

Territorial application

This Framework Decision shall apply to Gibraltar.

Article 13

Entry into force

This Framework Decision shall enter into force on the day of its publication in the Official Journal.

Done at Luxembourg, 13 June 2002.

For the Council

The President

M. Rajoy Brey 